UNIVERSIDADE DE SÃO PAULO

INSTITUTO DE GEOCIÊNCIAS

\title{
CUSTO DE ENERGIA ELÉTRICA NO BOMBEAMENTO DE POÇOS EM ÁREAS DE INTENSA EXPLOTAÇÃO: ESTUDO DE CASO EM SÃO JOSÉ DO RIO PRETO - SP
}

\section{Mateus Delatim Simonato}

Orientador: Prof. Dr. Ricardo César Aoki Hirata

\section{DISSERTAÇÃO DE MESTRADO}

Programa de Pós-Graduação em Recursos Minerais e Hidrogeologia

SÃO PAULO

2012

(Versão Original) 
À minha esposa Vanessa, ao meu filho João e à minha filha Manuela, meus amores. 


\section{AGRADECIMENTOS}

Agradeço primeiramente à minha família. À minha esposa Vanessa por toda parceria, dedicação, compreensão, suporte, companheirismo e ajuda. Aos meus filhos que, mesmo inconscientemente, toleraram e entenderam minhas ausências.

Agradeço ao Hirata (Prof. Dr. Ricardo Hirata), orientador e amigo, pelos ensinamentos, pela oportunidade, pela confiança depositada, pelas revisões, pela disponibilidade de ouvir e de falar sempre que procurado.

Agradeço à minha mãe Bete, por todo amor doado, valores ensinados e por todo esforço feito para minha formação que alicerçou tudo que sou e que tenho. Agradeço também pela ajuda na revisão da dissertação.

Agradeço também ao meu pai Odair, à minha irmã Juliana, ao meu irmão Daniel, aos meus sogros Chiquinho e Cida. Ao Daniel ainda agradeço seus dons artísticos aplicados na ilustração desta dissertação.

Agradeço ao Departamento de Águas e Energia Elétrica (DAEE), especialmente ao Geol. José Eduardo Campos (Zk) que viabilizou a disponibilização dos dados utilizados para o desenvolvimento desta pesquisa. Ao amigo Zk também agradeço pelos momentos de discussão sobre o tema e pelas contribuições de sua vasta experiência de atuação no órgão gestor dos recursos hídricos do Estado de São Paulo.

Agradeço à Servmar Serviços Técnicos Ambientais, em especial ao Leandro (Leandro Faria) e ao Maurício (Eng. Maurício Prado Alves), diretores da Servmar, pela oportunidade e pelo apoio.

Aos amigos Simanke (Dr. João Carlos Simanke de Souza), Márcio (Geol. Márcio Costa Abreu), Ana Maciel (Geol. Ana Maciel de Carvalho), Luciana (Eng. Luciana Cibele Santos) e Camila (Eng. Camila Ortolan), agradeço imensamente pelas efetivas contribuições a esta dissertação.

Agradeço ao amigo, Rômulo (Prof. Dr. Rômulo Machado) que, desde a graduação, sempre me orientou para a formação, para a ciência e para a vida.

Agradeço a todos, anonimamente, que direta ou indiretamente contribuíram com o alcance desta meta.

Agradeço a Deus. 


\section{RESUMO}

SIMONATO, M. D. Custo de energia elétrica no bombeamento de poços em área de intensa explotação: estudo de caso em São José do Rio Preto - SP. 2012. 141f. Dissertação (Mestrado) - Instituto de Geociências, Universidade de São Paulo, São Paulo, 2012.

Esta pesquisa objetivou a avaliação de custos de energia elétrica no bombeamento de poços, em área de intensa explotação das águas subterrâneas do Sistema Aquífero Bauru (SAB), em São José do Rio Preto - SP (SJRP) e foi conduzida em sinergia com uma abordagem multifocal de avaliação como ferramenta à gestão do uso das águas subterrâneas em áreas urbanas. A área de estudo, com $728 \mathrm{~km}^{2}$, abrange quase totalmente o município, onde o modelo de uso das águas subterrâneas provocou rebaixamentos dos níveis potenciométricos do $\mathrm{SAB}$ na zona urbana, evidenciados em modelos numéricos de fluxo subterrâneo. $\mathrm{O}$ desenvolvimento desta pesquisa contemplou a seleção, análise e interpretação de dados do cadastro de poços do Departamento de Águas e Energia Elétrica e a geração de mapas de profundidade dos níveis de água, visando à caracterização do uso das águas subterrâneas em SJRP e aos cálculos do consumo de energia elétrica na explotação. As águas subterrâneas do SAB são responsáveis por $64 \%$ de todo o suprimento hídrico de SJRP, explotadas por 180 poços de abastecimento público e quase 1.800 poços particulares para usos diversos, segundo a base de dados de 2008. Os poços particulares, na grande maioria não outorgados, respondem por $60 \%$ de toda a captação do $\mathrm{SAB}$, evidenciando forte dependência do suprimento às alternativas individuais de infraestrutura hídrica. A comparação entre diferentes cenários de explotação simulados por modelação numérica de fluxo subterrâneo constatou a ocorrência de incrementos no consumo e no custo de energia elétrica na explotação, caracterizando a externalidade decorrente do modelo de uso das águas subterrâneas do SAB em SJRP a todos os usuários; e também o aumento da despesa com energia na captação dos poços públicos provocado por influência da captação dos poços particulares, caracterizando a externalidade gerada pelo uso privado à coletividade. Avaliou-se também que os sistemas de bombeamento instalados nos poços possuem baixo rendimento, demandando maior consumo de energia na explotação de água. Esta pesquisa concluiu que ocorre a superexplotação do SAB na zona urbana de SJRP, porém, com a possibilidade de ser mitigada com o adequado manejo das disponibilidades hídricas subterrâneas adjacentes ao perímetro urbano.

Palavras-chave: Água subterrânea. Superexplotação. Externalidade. Consumo de energia elétrica. 


\section{ABSTRACT}

SIMONATO, M. D. Eletric energy costs on pumping wells in an intensive explotation area: São José do Rio Preto - SP case study. 2012. 141f. Dissertação (Mestrado) - Instituto de Geociências, Universidade de São Paulo, São Paulo, 2012.

This research aimed to evaluate the cost of electrical energy involving the pumping of wells in areas of intensive groundwater use in Bauru Aquifer System (BAS), in São José do Rio Preto - SP (SJRP) and it was conducted as a focusing contribute on management tool for the groundwater use in urban areas. The study area, $728 \mathrm{~km}^{2}$, means almost the whole municipal total area, in which the pumping of groundwater has caused aquifer drawdown effects on BAS in the urban area, as it is evidenced by groundwater flow mathematical models. The development of this resource assembles the selection, analysis and data interpretation of the well registered with the Water Management State Agency besides designing of water table depth maps, in order to provide the characterization of the groundwater use in SJRP and the calculation of electrical energy consumption along the exploitation. BAS supplies $64 \%$ of groundwater to the whole water supply of SJRP, exploited by 180 municipal wells and almost 1.800 private wells dedicated for several uses, accordingly to the data from 2008. Water supply system is strongly dependable of the private wells that most of them are not licensed. The private wells are responsible for $60 \%$ of the total BAS explotation. The comparison between the different exploitation scenery simulated by groundwater flow mathematical models shows the occurrence of electrical energy consumption and cost increments along the exploitation, meaning an externality to all users due BAS groundwater development in SJRP; and also the increment of electrical energy spends for municipal wells caused by the influence of the exploitation of the private wells, meaning an externality caused by the private use to collectivity. It was also analyzed the pumping system installed in the well that has low performance, requiring a greater energy consumption during the water exploitation. This research concluded that occurs an overexploitation of BAS in the urban area of SJRP, however, there are possibilities to mitigate considering the appropriated management of the safe yield in the surroundings of the urban perimeter.

Keywords: Groundwater. Overexplotation. Externality. Eletric energy consumption 


\section{LISTA DE FIGURAS}

Figura 1.1 - Organograma simplificado e temática dos trabalhos do grupo de pesquisas vinculado ao Centro de Pesquisas de Águas Subterrâneas do Instituto de Geociências - USP

Figura 3.1 - Localização da área de estudo 26

Figura 3.2 - Mapa de uso e ocupação do solo na área de estudo (DAEE, 2008) 28

Figura 3.3 - Bacia Hidrográfica do Rio Turvo/Grande e as Sub Bacias (IPT, 1999) 30

Figura 3.4 - Mapa geológico do Grupo Bauru no Estado de São Paulo (modificado de Paula e Silva, 2003) 32

Figura 3.5 - Relações estratigráficas das formações do Grupo Bauru no Estado de São Paulo com destaque à sequência estratigráfica em SJRP (adaptado de Paula e Silva et al., 2003) 34

Figura 3.6 - Mapa de isópacas do Grupo Bauru em São José do Rio Preto 36

Figura 3.7 - Área de abrangência do Sistema Aquífero Bauru no Estado de São Paulo com a indicação esquemática simplificada do mapa de aquíferos do Estado (adaptado de SÃO PAULO, 2005; IRITANI; EZAKI, 2009) 39

Figura 3.8 - Mapa potenciométrico do Sistema Aquífero Bauru (modificado de CAMPOS et al., 2000)

Figura 3.9 - Gráficos de frequência dos parâmetros hidráulicos de condutividade hidráulica (a), transmissividade (b), vazão específica (c) e vazão de explotação (d) do Sistema Aquífero Bauru em São José do Rio Preto 44

Figura 3.10 - Gráfico da distribuição das fontes hídricas do abastecimento público de SJRP no ano de 2010 com informação sobre aos percentuais de água subterrânea e superficial

Figura 3.11 - Estimativa das perdas do sistema de distribuição de água de SJRP no ano de 2010 com base na diferença dos volumes produzido e faturado 49

Figura 3.12 - Localização dos poços de abastecimento público de São José do Rio Preto..... 50

Figura 3.13 - Gráfico de frequência dos dados de profundidade dos poços 51

Figura 3.14 - Distribuição dos poços na área de estudo classificados em faixas de profundidade construtiva 52

Figura 3.15 - Localização dos poços na área de estudo com a distinção entre poços outorgados e sem outorga de uso das águas 
Figura 3.16 - Distribuição dos usos das águas subterrâneas nos setores econômicos. 55

Figura 3.17 - Localização dos poços na área de estudo classificados pela finalidade de uso .57 Figura 3.18 - Gráfico da distribuição de dados de vazão por categoria com a indicação da quantidade de registros disponíveis, indisponíveis e poços desativados

Figura 3.19- Distribuição de poços na área de estudo classificados de acordo com a disponibilidade de dados de vazão

Figura 3.20- Disponibilidade de dados de vazão por categoria para os poços de abastecimento público e para as demais finalidades

Figura 3.21- Análise em 74 poços das explotações calculadas com dados de vazão indicada compradas às explotações obtidas com as vazões medidas

Figura 3.22- Gráficos dos volumes explotados do SAB em SJRP especificados pelo tipo uso e pelas categorias de dados de vazões

Figura 3.23 - Localização das áreas dos modelos numéricos de fluxo subterrâneo do SAB na área de estudo com destaque ao contorno da intersecção de ambos os modelos 70

Figura 3.24 - Mapa potenciométrico gerado por modelo numérico de fluxo subterrâneo do SAB em SJRP com a simulação do fluxo natural sem a influência de bombeamentos (DAEE, 2008). 72

Figura 3.25 - Mapa potenciométrico gerado por modelo numérico de fluxo subterrâneo do SAB em SJRP, referente à explotação de $98.000 \mathrm{~m}^{3} /$ dia (DAEE, 2008). 73

Figura 3.26 - Mapa potenciométrico gerado por modelo numérico de fluxo subterrâneo do SAB em SJRP, referente à explotação de $160.000 \mathrm{~m}^{3} /$ dia (Carvalho, 2012). .74

Figura 3.27 - Mapa potenciométrico gerado por modelo numérico de fluxo subterrâneo do SAB em SJRP, referente à explotação de $240.000 \mathrm{~m}^{3} /$ dia (Carvalho, 2012). 76

Figura 3.28 - Mapa potenciométrico gerado por modelo numérico de fluxo subterrâneo do $\mathrm{SAB}$, referente à explotação de $47.000 \mathrm{~m}^{3} /$ dia realizada somente pelos poços de abastecimento público (Carvalho, 2012). 77

Figura 5.1 - Esquema de um poço em bombeamento com a demonstração do cone de rebaixamento e de elementos constituintes do poço (adaptado de CUSTODIO; LLAMAS, 2001) 83

Figura 5.2 - Esquema de bombeamento de poços em interferência com a sobreposição de cones de rebaixamento (adaptado de FETTER, 2001).

Figura 5.3 - Ilustração esquemática de um poço em bombeamento com demonstração da formação do cone de rebaixamento e dos diversos efeitos que influenciam o rebaixamento do nível piezométrico (adaptado de CUSTODIO; LLAMAS, 2001)... 85 
Figura 5.4 - Tipos de curvas características de poço mostradas no gráfico "Q (vazão) / s (rebaixamento no poço)": a) em aquífero confinado sem a perda de carga no poço; b) em aquífero livre sem a perda no poço; c) comportamento com perdas de carga no poço (adaptado de CUSTODIO; LLAMAS, 2001) .................................................. 86

Figura 5.5 - Curva característica de bomba submersa ....................................................... 88

Figura 5.6 - Gráfico de "Q (vazão) / H (altura manométrica)" contendo as curvas características da bomba $(\mathrm{H})$ e da tubulação edutora $\left(\mathrm{H}_{1} \mathrm{~A}\right)$, a indicação do ponto de melhor eficiência do sistema de bombeamento (M) e a curva de eficiência do sistema $(\rho)$ 90

Figura 5.7- Gráficos esquemáticos da potência consumida durante o arranque de motor elétrico: a) com partida direta; b) com autotransformador; c) com partida suave; d) com inversor de frequência (adaptado de Perroni, 2005)............................................ 92

Figura 5.8 - Gráficos de vazão de explotação, consumo e custo de energia elétrica, demonstrando os percentuais de participação para os tipos de uso, calculados em 273 poços do cadastro.

Figura 5.9 - Gráficos de comparação das taxas de produtividade entre os diferentes tipos de uso das águas subterrâneas

Figura 5.10 -- Gráfico de correlação entre a taxa de produtividade $\left(\mathrm{R} \$ / \mathrm{m}^{3}\right)$ e o rendimento dos sistemas de bombeamento $\left(\rho_{\mathrm{s}}\right)$ em 273 poços do cadastro 99

Figura 5.11 - Modelo digital de elevação (topografia) do terreno na área de estudo 102

Figura 5.12 - Ilustração esquemática do método de geração dos mapas de profundidade do nível de água do SAB em SJRP (C), resultantes da diferença entre as cotas topográficas do modelo digital de elevação (A) e das cotas potenciométricas obtidas nos modelos numéricos de fluxo subterrâneo (B) 103

Figura 5.13 - Mapa de profundidade do nível de água do SAB em SJRP referente à explotação de $98.000 \mathrm{~m}^{3} /$ dia (Cenário 1) 106

Figura 5.14 - Mapa de profundidade do nível de água do SAB em SJRP referente à explotação de $160.000 \mathrm{~m}^{3} /$ dia (Cenário 2) 107

Figura 5.15 - Mapa de profundidade do nível de água do SAB em SJRP referente à explotação de $240.000 \mathrm{~m}^{3} /$ dia (Cenário 3) 108

Figura 5.16 - Mapa de profundidade do nível de água do SAB em SJRP referente à explotação de $47.000 \mathrm{~m}^{3} /$ dia somente pelos poços de abastecimento público (Cenário 4). 
Figura 6.1 - Volumes explotados do SAB em SJRP por finalidade de uso das águas subterrâneas

Figura 6.2 - Gráfico de comparação entre os cenários de simulação da explotação do SAB em SJRP com a demonstração da vazão de explotação, consumo e o custo de energia elétrica

Figura 6.3 - Gráfico da correlação entre o custo de energia elétrica na explotação das águas subterrâneas e a profundidade média do nível de água

Figura 6.4 - Gráfico de comparação entre os cenários de simulação da explotação do SAB em SJRP com a demonstração da eficiência de produção de água

Figura 6.5 - Gráfico de comparação entre os cenários de simulação da explotação do SAB em SJRP pelos poços de abastecimento público com a demonstração da vazão de explotação, consumo e o custo de energia elétrica 121

Figura 6.6 - Gráfico de comparação entre os cenários de simulação da explotação do SAB em SJRP demonstrando a eficiência de produção de água nos poços de abastecimento público..... 121

Figura 6.7 - Gráfico de comparação dos dados de vazão de explotação, consumo e custo de energia elétrica dos cenários simulados da explotação do SAB com as estimativas baseadas em dados reais do cadastro de poços do DAEE (2008)

Figura 6.8 - Gráficos de comparação das taxas de eficiência de produção de água dos cenários simulados da explotação do $\mathrm{SAB}$ com as estimativas baseadas em dados reais do cadastro de poços do DAEE (2008)

Figura 6.9 - Gráfico de comparação da profundidade média do nível de água dos cenários simulados da explotação do SAB com a média dos dados do cadastro para o mesmo elenco de poços

Figura 6.10 - Gráfico da correlação entre o custo de energia elétrica na explotação das águas subterrâneas e a profundidade média do nível de água 125

Figura 6.11 - Gráficos de comparação das taxas de eficiência de produção de água dos cenários simulados da explotação do SAB com duas estimativas baseadas em dados reais do cadastro de poços do DAEE (2008) e diferentes dados de profundidade de nível de água 


\section{LISTA DE TABELAS}

Tabela 3.1 - Parâmetros hidráulicos do Sistema Aquífero Bauru em São José do Rio Preto* 42

Tabela 3.2 - Fontes e volumes do abastecimento público de água de SJRP 48

Tabela 3.3 - Estimativas das perdas da rede de distribuição de água 48

Tabela 3.4 - Volumes explotados do SAB em SJRP por tipo de uso e categorias de dados de vazão

Tabela 5.1 - Valores dos parâmetros de interesse e do consumo de energia elétrica obtidos com base nos dados do cadastro de poços

Tabela 5.2 Parâmetros de interesse e valores dos cálculos de consumo de energia elétrica nos cenários de explotação do SAB em SJRP 105

Tabela 5.3 - Parâmetros de interesse e valores dos cálculos de consumo de energia elétrica dos poços públicos nos cenários de explotação do SAB em SJRP 


\section{LISTA DE ABREVIATURAS}

ABNT - Associação Brasileira de Normas Técnicas

APP - Área de Proteção Permanente

BH-TG - Bacia Hidrográfica Turvo Grande

CEPAS - Centro de Pesquisas de Águas Subterrâneas (integrado ao Instituto de Geociência da Universidade de São Paulo)

CPFL - Companhia Paulista de Força e Luz

CPRM - Companhia de Pesquisa dos Recursos Minerais - Serviço Geológico do Brasil

CRH - Conselho Estadual de Recursos Hídricos (Estado de São Paulo)

CTAS - Câmara Técnica de Águas Subterrâneas (comissão permanente constituída no âmbito do Conselho Estadual de Recursos Hídricos)

DAEE - Departamento de Águas e Energia Elétrica

EMBRAPA - Empresa Brasileira de Pesquisa Agropecuária

FEHIDRO - Fundo Estadual de Recursos Hídricos

IBGE - Instituto Brasileiro de Geografia e Estatística

IPT - Instituto de Pesquisas Tecnológicas

LAMO - Laboratório de Modelos Físicos (integrado ao Instituto de Geociência da Universidade de São Paulo)

MDE - Modelo digital de elevação (mapa topográfico obtido por imageamento digital)

PMSJRP - Prefeitura Municipal de São José do Rio Preto

SAB - Sistema Aquífero Bauru

Sabesp - Companhia de Saneamento Básico do Estado de São Paulo

SAG - Sistema Aquífero Guarani

Semae - Serviço Municipal Autônomo de Água e Esgoto

SIG - Sistema de informações georreferenciadas

SJRP - São José do Rio Preto

SNIS - Sistema Nacional de Informações sobre Saneamento

SRTM - Missão espacial de topografia por radar (sigla em inglês para Shuttle Radar Topography Mission)

UGRHI - Unidade de Gerenciamento dos Recursos Hídricos 


\section{SUMÁRIO}

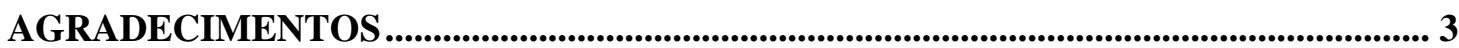

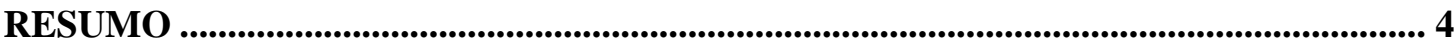

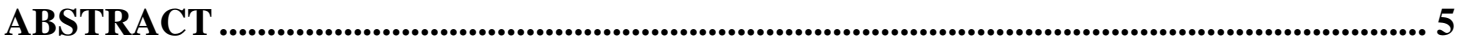

LISTA DE FIGURAS ............................................................................................................... 6

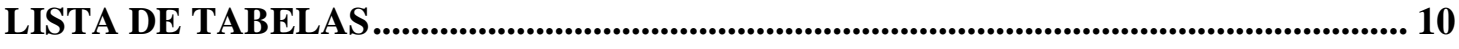

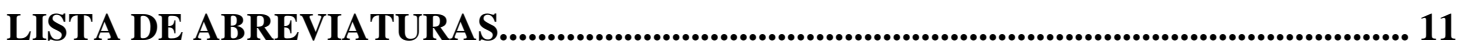

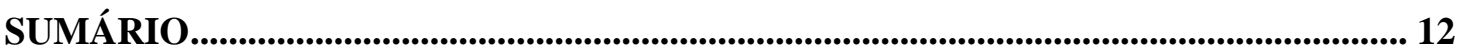

1 INTRODUÇÃ

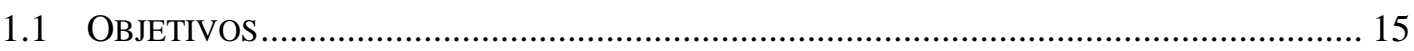

1.2 CONTEXTUALIZAÇÃO DO DESENVOLVIMENTO DA PESQUISA ……................................ 16

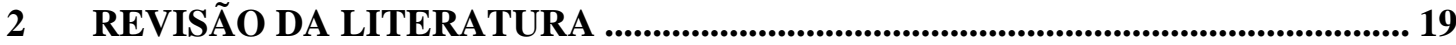

2.1 SUPEREXPLOTAÇÃO OU USO INTENSO? A VISÃO MODERNA NA AVALIAÇÃO DOS

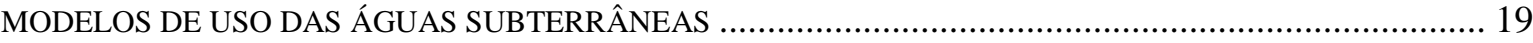

2.2 CONSUMO DE ENERGIA NA PRODUÇÃO DE ÁGUA ……………………...................... 22

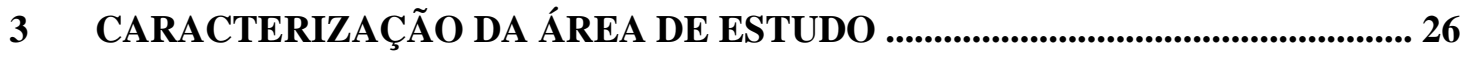

3.1 ASPECTOS DEMOGRÁFICOS E DE OCUPAÇÃO TERRITORIAL …...................................... 27

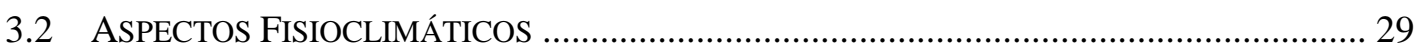

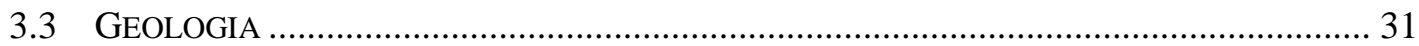

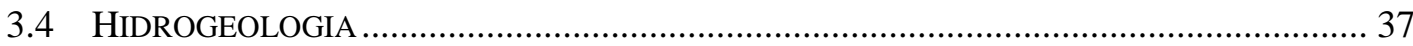

3.5 INFRAESTRUTURA HÍDRICA DE ABASTECIMENTO DE ÁGUA ........................................ 46

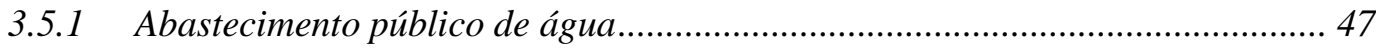

3.5.2 Caracterização da rede de poços de captação do $S A B$...................................... 51

3.5.3 Explotação das águas subterrâneas do SAB ....................................................... 58

3.6 O DESENVOLVIMENTO DO USO DAS ÁGUAS SUBTERRÂNEAS DO SAB ...........................6 65

3.7 A EXPLOTAÇÃO DO SAB SIMULADA POR MODELAÇÃO NUMÉRICA .............................. 69

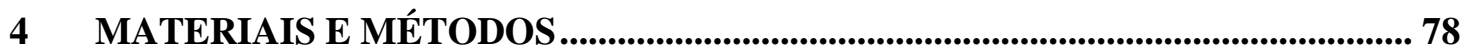

4.1 IDENTIFICAÇÃO DOS DADOS DISPONÍVEIS NO CADASTRO E A DETERMINAÇÃO DO

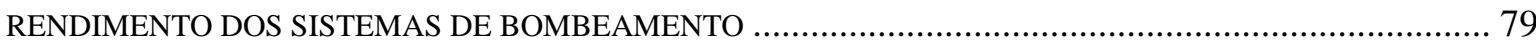

4.2 DETERMINAÇÃO DA VAZÃo DE BOMBEAMENTO DOS POÇOS E O CÁLCULO DE

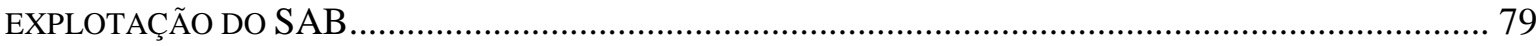

4.3 A DETERMINAÇÃO DO PARÂMETRO DE ALTURA MANOMÉTRICA.................................. 80

4.4 DETERMINAÇÃO DO CONSUMO E DOS CUSTOS DE ENERGIA ELÉTRICA NO BOMBEAMENTO

5 CONSUMO ENERGÉTICO NA EXPLOTAÇÃO DAS ÁGUAS SUBTERRÂNEAS 
5.1 FUNDAMENTOS DA EXPLOTAÇÃO DAS ÁGUAS SUBTERRÂNEAS E A INFLUÊNCIA NO CONSUMO DE ENERGIA

5.2 ANÁLISE DO CONSUMO DE ENERGIA ELÉTRICA EM POÇOS DO CADASTRO E A AVALIAÇÃO DO RENDIMENTO NA EXPLOTAÇÃO.

5.3 ESTIMATIVA DO CONSUMO DE ENERGIA ELÉTRICA NA EXPLOTAÇÃO DO SISTEMA AQUífERo BAURU EM SÃo JOSÉ DO RIO PRETO.

6 DISCUSSÕES DE RESULTADOS................................................................... 112

6.1 A EXPLOTAÇÃO DO SAB E O PADRÃO DE CONSUMO DE ÁGUA EM SJRP. 112

6.2 O MODELO DE USO DAS ÁGUAS SUBTERRÂNEA DO SAB EM SJRP E OS EFEITOS NO CUSTO DE ENERGIA ELÉTRICA NA EXPLOTAÇÃO.

6.2.1 Avaliação das externalidades no custo de energia elétrica provocadas pelo modelo de explotação das águas subterrâneas.

6.2.2 Análise do modelo de uso das águas subterrâneas pelos poços de abastecimento público e a avaliação de externalidades provocadas à coletividade pelo uso particular das águas subterrâneas

6.2.3 Avaliação de custos extras de energia elétrica provocados pelo padrão de rendimento dos sistemas de bombeamento em operação

6.3 AVALIAÇÃO DA EXISTÊNCIA DE SUPEREXPLOTAÇÃO DO SAB EM SJRP... 127

7 CONCLUSÕES 130

8 REFERÊNCIAS BIBLIOGRÁFICAS 


\section{INTRODUÇÃO}

A região de São José do Rio Preto, mais precisamente, a zona urbana desse município, possui características emblemáticas do desenvolvimento do uso da água subterrânea. Situado à cerca de $450 \mathrm{~km}$ a noroeste da capital do Estado de São Paulo, esse município possui seu abastecimento de água fortemente alicerçado na explotação da água subterrânea.

Indícios de rebaixamento das cargas hidráulicas do Sistema Aquífero Bauru (SAB), em algumas áreas da zona urbana de São José do Rio Preto (SJRP), foram identificados e discutidos em estudos realizados na região (OLIVEIRA, 2002; LIMA, 2004; DAEE, 2008). Esse cenário situa São José do Rio Preto em um patamar comum a diversos centros urbanos do Brasil e do Mundo, no qual é pertinente a discussão sobre modelos sustentáveis do uso do recurso hídrico, sobretudo, diante de um possível cenário de superexplotação da água subterrânea.

A discussão sobre a temática de superexplotação de aquíferos vem ocorrendo de maneira acentuada nas últimas décadas, a reboque de discussões e avaliações dos modelos de uso e da disponibilidade de água no mundo. Destaca-se a visão defendida por Llamas (2003), na qual, a superexplotação não pode ser definida apenas sob o aspecto hidrogeológico, caracterizado por rebaixamento dos níveis do aquífero, sem considerar, no mesmo contexto, os aspectos ambientais, ecológicos, sociais e econômicos influenciados pelo modelo de utilização do aquífero.

A importância de uma avaliação multifocal se torna evidente, uma vez que a água subterrânea vem assumindo um significativo papel no abastecimento de água e que, os aspectos positivos de seu uso devem ser avaliados conjuntamente aos efeitos negativos.

Os estudos anteriores realizados na região de São José do Rio Preto concentraram-se fortemente nos aspectos hidrogeológicos e, em alguns casos, com foco na gestão dos recursos hídricos subterrâneos. Entretanto, não existem estudos abordando os demais aspectos (ecológicos, sociais e econômicos) que permitem uma análise multifocal do cenário de uso das águas subterrâneas.

Embasado nos conceitos de abordagem multifocal na avaliação da superexplotação, este projeto de pesquisa focou principalmente no aspecto econômico, buscando respostas à seguinte questão: os efeitos do uso intenso das águas subterrâneas do Sistema Aquífero Bauru em São José do Rio Preto afetam os custos de energia elétrica do bombeamento das águas? 
Novas abordagens na análise sobre as potencialidades das águas subterrâneas e sobre os efeitos à sociedade do modelo de uso desse recurso hídrico são importantes para romper o estigma criado de que a água subterrânea é frágil.

Atualmente, o abastecimento público de São José do Rio Preto é fortemente dependente das águas subterrâneas e, o suprimento às demandas hídricas totais, ainda conta com uma importante contribuição de usos particulares das águas subterrâneas do Sistema Aquífero Bauru. Certamente, o desenvolvimento e o padrão de vida da sociedade riopretense foram influenciados pela facilidade de acesso à água.

A avaliação integrada dos fatores que influenciam ou são influenciados pelo desenvolvimento do uso da água subterrânea na região pode levar ao estabelecimento de modelos de atendimento às necessidades locais com os menores impactos ao meio ambiente e com os melhores indicadores de sustentabilidade econômica e ambiental.

O desenvolvimento desta pesquisa foi motivado pelo desejo de ampliar o conhecimento acerca do modelo de explotação das águas subterrâneas em São José do Rio Preto e de estabelecer indicadores para o uso sustentável dos recursos hídricos subterrâneos, visando contribuir com a manutenção e o acesso a esta importante fonte renovável de água que é o Sistema Aquífero Bauru.

\subsection{OBJETIVOS}

Este projeto de pesquisa objetivou a análise do consumo de energia elétrica no bombeamento de poços existentes no município de São José do Rio Preto - SP, visando à avaliação da ocorrência de custos extras de energia (externalidades) provocados pelo modelo de intensa explotação das águas subterrâneas do Sistema Aquífero Bauru, na zona urbana do município.

Paralelamente ao objetivo principal, o desenvolvimento desta pesquisa visou aos seguintes objetivos específicos:

- caracterização do modelo de uso das águas subterrâneas do SAB, visando à quantificação do volume explotado e à caracterização do padrão de consumo de água em São José do Rio Preto; 
- reconhecimento do uso da água subterrânea por poços particulares e a discussão sobre a importância das iniciativas individuais na implementação da infraestrutura hídrica e no uso sustentável dos recursos hídricos;

- análise do consumo de energia elétrica na explotação com base nas informações reais disponíveis, visando à avaliação da eficiência dos sistemas de bombeamento em operação e ao estabelecimento de padrões para o cálculo do consumo de energia;

- avaliação da ocorrência de superexplotação do SAB com base em fatores hidrogeológicos e econômicos associados ao modelo de uso das águas subterrâneas existente em SJRP.

\subsection{CONTEXTUALIZAÇÃO DO DESENVOLVIMENTO DA PESQUISA}

O modelo de uso das águas subterrâneas do Sistema Aquífero Bauru em São José do Rio Preto é alvo de interesse de inúmeros estudos, pesquisas e, principalmente, de acompanhamento e preocupação das autoridades relacionadas à gestão dos recursos hídricos.

O cenário de intenso uso das águas subterrâneas, evidenciado pelos rebaixamentos dos níveis potenciométricos na região central da cidade, motivou a inclusão do município de São José do Rio Preto em uma lista de áreas críticas, elaborada pela Câmara Técnica de Águas Subterrâneas (CTAS), do Conselho Estadual de Recursos Hídricos (CRH). Na primeira versão da referida lista, foram incluídas oito localidades com históricos de problemas relacionados à quantidade e/ou qualidade das águas subterrâneas.

Os problemas encarados pelos órgãos gestores dos recursos hídricos e do meio ambiente desencadearam, nas duas últimas décadas, um processo de ampliação do arcabouço legal do Estado, visando ao fortalecimento e à regulamentação de mecanismos de gestão.

Embasada em diretrizes previstas em normas legais do Estado, com destaque à Lei $\mathrm{N}^{\mathrm{o}}$ 6.134, de 02 de junho de 1988, ao Decreto $\mathrm{N}^{\mathrm{o}}$ 32.955, de 07 de fevereiro de 1991, e à Resolução CRH N ${ }^{0}$ 52, de 15 de abril de 2005, a Secretaria de Saneamento e Recursos Hídricos do Estado de São Paulo, por meio do Departamento de Águas e Energia Elétrica (DAEE), contratou a execução de um estudo hidrogeológico intitulado "Delimitação de Áreas de Restrição e Controle de Captação e Uso de Águas Subterrâneas no Município de São José do Rio Preto - Bloco A - Aquífero Sedimentar". Esse estudo foi custeado com recursos financeiros do Fundo Estadual de Recursos Hídricos (FEHIDRO). 
O estudo hidrogeológico foi executado pela empresa Servmar Serviços Técnicos Ambientais Ltda. (Servmar Ambiental), sendo que o autor desta pesquisa atuou como gerente técnico, participando da execução e da equipe de coordenação dos trabalhos. Os resultados alcançados no referido estudo estão apresentados no Relatório Final (DAEE, 2008) que conta ainda com uma enorme base de dados com destaque ao cadastro digital de poços produtores.

Deve-se destacar que a maioria dos dados utilizados no desenvolvimento desta pesquisa foi obtida da base de dados, dos relatórios e do cadastro de poços, resultantes dos trabalhos da Servmar Ambiental, gentilmente disponibilizados pelo DAEE.

Os dados obtidos nos estudos do DAEE (2008), bem como o cenário de uso da água subterrânea em São José do Rio Preto despertaram o interesse do grupo de pesquisa vinculado ao Centro de Pesquisas de Águas Subterrâneas (CEPAS) e ao Laboratório de Modelos Analíticos (LAMO), integrados ao Instituto de Geociências da Universidade de São Paulo.

A Figura 1.1 ilustra o organograma simplificado e as linhas gerais dos trabalhos realizados pelo grupo, coordenado pelo Prof. Dr. Ricardo Cesar Aoki Hirata, demonstrando o caráter integrado e multifocal das pesquisas que visam ao desenvolvimento de ferramentas e indicadores para a gestão sustentável dos recursos hídricos subterrâneos.

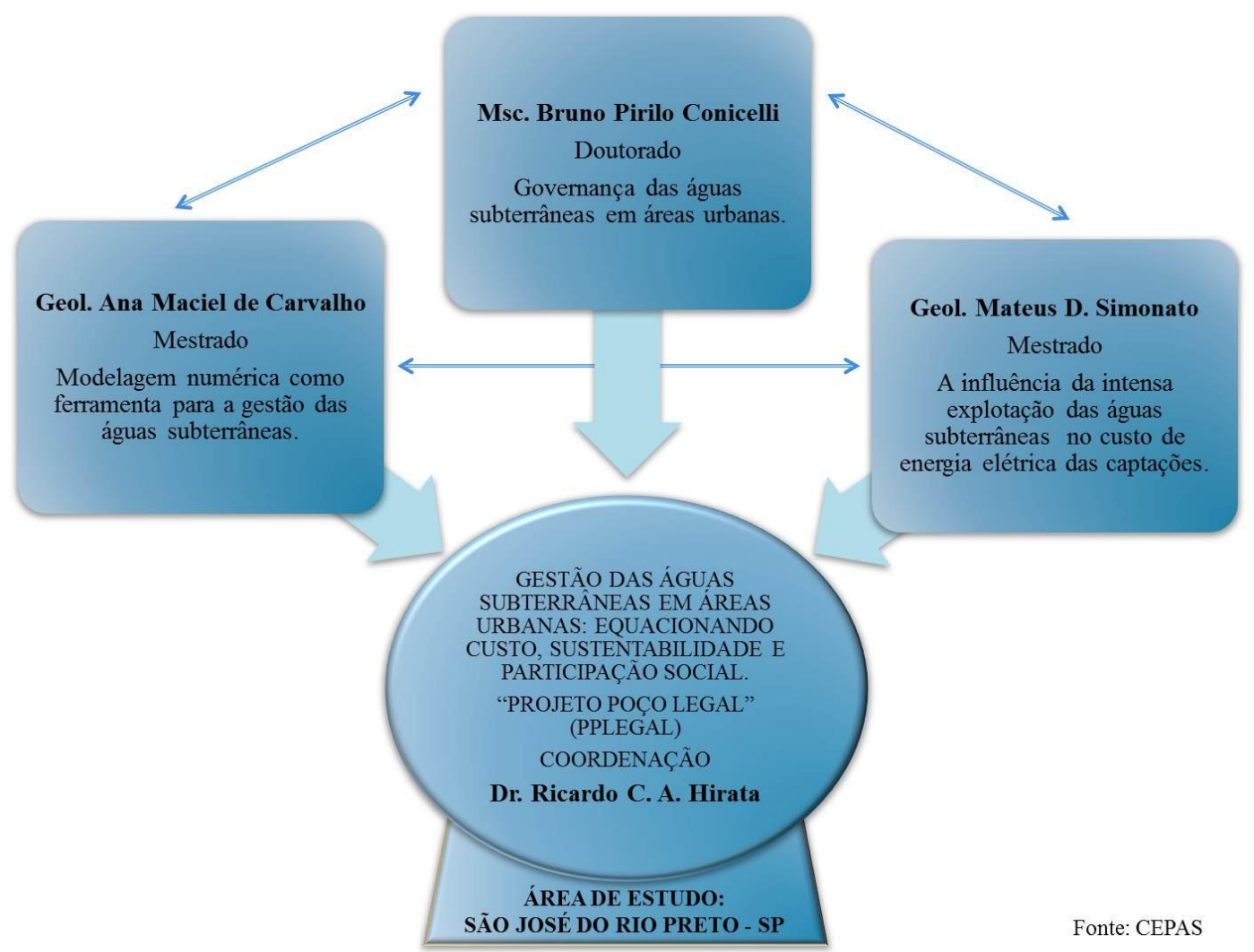

Figura 1.1 - Organograma simplificado e temática dos trabalhos do grupo de pesquisas vinculado ao Centro de Pesquisas de Águas Subterrâneas do Instituto de Geociências - USP 
Diante da sinergia e integração das temáticas conduzidas pelo referido grupo é que parte dos dados e/ou dos resultados de uma pesquisa contribuiu ou poderá contribuir com o desenvolvimento de outra. Por exemplo, o presente trabalho contou com resultados parciais apresentados no relatório de qualificação da mestranda Geol. Ana Maciel de Carvalho, mais precisamente com mapas potenciométricos produzidos por modelação numérica. Esses mapas potenciométricos foram utilizados neste estudo na avaliação dos custos de energia elétrica na explotação das águas subterrâneas em diferentes cenários simulados numericamente.

A temática do presente estudo concentra-se na avaliação de aspectos econômicos relacionados à intensa explotação das águas subterrâneas, enquanto os demais trabalhos do grupo, atualmente em curso, abordam temas de ordem técnica, principalmente no detalhamento do conhecimento hidrogeológico como ferramenta para a gestão dos recursos hídricos, mas também de comunicação e integração social e governança participativa. 


\section{REVISÃO DA LITERATURA}

O desenvolvimento do presente trabalho foi fundamentado pelos conceitos modernos, multifocais, de avaliação dos cenários de uso intenso das águas subterrâneas e na análise econômica do consumo de energia elétrica no bombeamento das águas subterrâneas com ênfase na influência dos efeitos do uso intenso nos custos.

\subsection{SUPEREXPLOTAÇÃO OU USO INTENSO? A VISÃO MODERNA NA AVALIAÇÃO DOS MODELOS DE USO DAS ÁGUAS SUBTERRÂNEAS}

É indiscutível a importância da água para qualquer forma de vida no planeta e, consequentemente, a escassez de água se torna temática de alta relevância na agenda mundial. Durante as últimas décadas, a expressão "regiões sob estresse hídrico" vem permeando a literatura sobre recursos hídricos (LLAMAS; CUSTODIO, 2003). Estimativas apontam que o estresse hídrico já assola cerca de 70 milhões de pessoas em 43 países (TERI, 2009).

O crescente aumento demográfico da população mundial, o desenvolvimento econômico e social, a evolução tecnológica, as consequentes pressões advindas da necessidade por maior volume de alimentos, o atendimento aos atuais paradigmas de consumo e os modelos de uso e ocupação da superfície terrestre tem sido os responsáveis pelo aumento do estresse hídrico, provocado por excessivas taxas de explotação e/ou por contaminações das águas.

As pressões que impulsionaram os excessivos aumentos das demandas hídricas e a diminuição da disponibilidade das águas superficiais propiciaram o desenvolvimento do uso das águas subterrâneas como fontes para o suprimento de água. Além desses motivos, Llamas e Martinez Cortina (2002) destacaram como causas do crescimento acelerado do uso da água subterrânea, o desenvolvimento de técnicas e equipamentos para perfuração de poços e bombeamento, o baixo custo de explotação da água e a falta de aplicação das normas que regulamentam e controlam sua utilização.

As águas subterrâneas possuem outros atrativos, adequados aos atuais modelos de utilização dos recursos hídricos: representam as maiores e mais importantes reservas de água potável disponível (HOWARD, 1997); são menos vulneráveis à contaminação que as águas superficiais; sofrem menor influência das oscilações climáticas; e permitem a aplicação 
planejada e descentralizada dos investimentos em infraestruturas, acompanhando o crescimento da demanda, sem necessitar de grandes investimentos relacionados a estações de tratamento e adução em longas distâncias.

Protagonista em uma "Revolução Silenciosa", a água subterrânea esteve invisível no desenvolvimento do seu uso, nas avaliações, nas agendas dos tomadores de decisão, nos arcabouços políticos e nas degradações que ocorriam sem uma percepção aparente (LLAMAS; MARTÍNEZ-SANTOS, 2004). Esse cenário de invisibilidade tem sido modificado a partir da diminuição da oferta hídrica por contaminação e/ou pelo aumento das demandas acima das disponibilidades.

Apesar da abundância e das características que favorecem o uso das águas subterrâneas, os modelos de desenvolvimento do seu uso desencadearam efeitos indesejáveis e situações de conflito, levando algumas regiões dependentes desses mananciais subterrâneos ao estresse hídrico. Entretanto, qual é o limite para avaliar que uma região está sob estresse hídrico?

No passado, uma análise meramente quantitativa determinava a existência de estresse hídrico. Eram consideradas regiões sob estresse hídrico aquelas cujo cálculo da oferta hídrica per capta possuía taxas inferiores a $1.000 \mathrm{~m}^{3} /$ ano/habitante (UNITED NATIONS, $1997^{1}$ apud LLAMAS; CUSTODIO, 2003). Em estudos mais recentes (UNESCO, 2003; UNESCO, 2009), as Nações Unidas utilizaram abordagens multifocais, nas quais as avaliações dependem de muitas variáveis, tais como: inúmeros atores (diversos níveis de governo e a sociedade civil, incluindo a representação dos setores econômicos) e diversificados fatores de pressão (finanças, uso do território, urbanização, poluição, padrões de consumo, disponibilidade física da água, mudanças climáticas, etc.).

A dicotomia existente entre os benefícios trazidos pelo uso da água e os fatores negativos causados pela intensa explotação ampliam as variáveis a serem analisadas no processo de gestão dos recursos hídricos e, sobretudo, na avaliação do cenário de estresse hídrico. Algumas afirmativas extraídas de trabalhos sobre a temática de uso intenso das águas subterrâneas ilustram a amplitude de variáveis temáticas na avaliação desses cenários:

"O uso da água subterrânea tem sido uma oportunidade de sustento a comunidades pobres" (SHAH et al., 2000);

“O desenvolvimento da água subterrânea ocorre sob escassa participação das agências governamentais" (LLAMAS; MARTINEZ CORTINA, 2002);

${ }^{1}$ UNITED NATIONS, 1997. China: Water resources and their use. Economic and Social Commission for Asia and the Pacific, New York, NY. 
“As legislações sobre a água subterrânea são, em geral, paliativas e corretivas, mais que preventivas" (GARRIDO; LIVINGSTON, 2003);

"Existem efeitos colaterais do uso da água subterrânea que podem causar a elevação dos custos diretos, o aumento das externalidades e desenvolvimento de custos intangíveis" (LLAMAS; CUSTODIO, 2003).

Nesse contexto de avaliar o desenvolvimento do uso da água subterrânea de maneira ampla e multifocal, a primeira discussão trazida por diversos autores (CUSTODIO, 1992; MARGAT, 1992; SOPHOCLEUS, 2000; CUSTODIO, 2002; CUSTODIO; LLAMAS, 2003) é sobre a definição imprecisa e meramente qualitativa do termo superexplotação. Em geral, esses autores discutem que o termo superexplotação deveria caracterizar o volume captado superior à recarga ou superior a um limite estabelecido, porém é utilizado para caracterizar uma região que sofre com efeitos negativos da explotação da água subterrânea (LLAMAS; CUSTODIO, 2003). Alternativamente, é utilizado o termo "uso intenso da água subterrânea" aplicado para caracterizar as situações de impacto no ciclo hidrológico causado pela explotação de água subterrânea (LLAMAS; CUSTODIO 2003), sem necessariamente configurar um cenário de superexplotação.

Llamas et al. (1992) sugerem uma alternativa para definir que um aquífero é superexplotado quando os custos econômicos, sociais e ambientais, provenientes de um dado volume de depleção dos níveis potenciométricos do aquífero, excedem os benefícios correspondentes. Ainda que a sugestão dos autores contenha uma complicada ação de dimensionar custos, externalidades e impactos ao sistema hidrogeológico, a proposta de uma abordagem multifocal é indispensável para que não seja negligenciado nenhum possível efeito negativo ou positivo do uso da água subterrânea.

Brown (2000) destaca algumas dificuldades associadas à caracterização e quantificação das externalidades; ao manejo do uso intenso das águas subterrâneas e à mitigação de externalidades avaliadas, conforme descrito a seguir:

- Ações individuais podem ter efeitos no espaço e tempo que são somente parcialmente conhecidos;

- Em muitos casos, os efeitos de ações coletivas não podem ser claramente separados de efeitos provocados por ações individuais anteriores;

- Os custos para implementar regimes e/ou mecanismos otimizados de explotação não são compatíveis com os benefícios alcançados; 
- Existem benefícios coletivos que estão associados a aquíferos que são explotados comercialmente por usuários privados.

Embora os diversos autores citado tenham retratado a dificuldade e a complexidade de avaliar com precisão a existência de superexplotação, é latente a necessidade de se avaliar os cenários considerando às necessidades atuais e futuras, bem como os aspectos hidrogeológicos, políticos, sociais e econômicos, em uma abordagem multifocal.

Embasados nessa abordagem multifocal, vem sendo desenvolvidos os trabalhos do grupo de pesquisa vinculado ao CEPAS/LAMO, do Instituto de Geociências da Universidade de São Paulo. Esta pesquisa, integrada ao referido grupo, focou a análise de aspectos econômicos, mais precisamente, na avaliação de possíveis incrementos no custo de energia elétrica na captação das águas subterrâneas, provocados pela intensa explotação e, consequentemente, na determinação de possíveis externalidades provocadas pelo modelo de uso das águas subterrâneas do Sistema Aquífero Bauru em São José do Rio Preto.

Os resultados alcançados com esta pesquisa, associados com avaliações já existentes sobre o cenário na região de interesse e, possivelmente, com outras futuras permitirão constituir um elenco de análises multifocais sobre as condições de explotação das águas subterrâneas em São José do Rio Preto e, desse modo, subsidiar medidas sustentáveis de gestão e controle do uso dos recursos hídricos subterrâneos.

\subsection{CONSUMO DE ENERGIA NA PRODUÇÃO DE ÁGUA}

Os trabalhos tratando dos aspectos econômicos da explotação das águas subterrâneas ainda são escassos. Desse modo, serão introduzidos alguns trabalhos que discutem, de maneira menos específica, a relevância do consumo de energia elétrica na captação / produção de água.

Mais de dois por cento do consumo total de energia elétrica do Brasil, o equivalente a 8,3 bilhões de kWh/ano, são consumidos nos processos de abastecimento de água e esgotamento sanitário, pelos prestadores de serviços de saneamento em todo o país, totalizando despesas da ordem de R \$ 1,5 bilhão (RECESA, 2008). Os conjuntos motobombas utilizados nas elevatórias de água e esgoto são responsáveis por cerca de $90 \%$ do consumo de energia elétrica (TSUTIYA, 1997; TSUTIYA; DAVID, 2005). 
A despesa com energia elétrica está entre os maiores itens de despesa das empresas de saneamento. Tsutiya (1997), considerando avaliações do consumo de energia nos sistemas da Companhia de Saneamento Básico do Estado de São Paulo (Sabesp), apontou que a energia elétrica representava $8 \%$ do total de despesas da companhia, correspondendo ao terceiro maior item de despesa, sendo que os sistemas operacionais de água e esgotos eram responsáveis por $98 \%$ do consumo.

Justificado pela discussão feita na introdução deste item, julgou-se relevante contextualizar a representatividade dos custos de energia nos sistemas de saneamento, apesar de as estimativas apresentadas anteriormente envolverem atividades que não são avaliadas no presente estudo, tais como o esgotamento sanitário, a captação de águas superficiais, o recalque para reservatórios e a distribuição de água. No entanto, deve-se destacar que também está incluído nas estimativas, o consumo de energia da explotação de mais de 1.100 poços tubulares, em operação nos sistemas de abastecimento da Sabesp, no interior do Estado de São Paulo (SABESP, 2012).

Os dados do Sistema Nacional de Informação sobre Saneamento (SNIS) registram que, em 2008, a despesa anual com energia elétrica do Serviço Municipal Autônomo de Água e Esgoto (Semae), autarquia responsável pelo abastecimento público de água de São José do Rio Preto, foi de $\mathrm{R} \$ 10.938 .147$, correspondendo a 33\% das despesas totais da empresa. Naquela ocasião, mais de 99\% do consumo de energia elétrica, $43.613 .000 \mathrm{kWh} / \mathrm{ano}$, estavam associados aos serviços de produção, tratamento e distribuição de água. Segundo a mesma fonte de dados, o volume de água produzido, em 2008, foi de $41.934 .000 \mathrm{~m}^{3}$, significando um valor de $\mathrm{R} \$ 0,26 / \mathrm{m}^{3}$ para a relação de custo de energia por volume unitário produzido.

No caso do Semae, os dados apresentados não incluem os custos e o consumo de energia associados ao esgotamento sanitário. No entanto, são indistintos para a produção, tratamento e distribuição de água. Nos dados de consumo total de energia elétrica, está incluído o consumo da operação de 8 poços superprofundos de captação do Sistema Aquífero Guarani e de 195 poços de captação do Sistema Aquífero Bauru (PMSJRP, 2009).

Em relação à temática de avaliação da eficiência energética de sistemas de bombeamento em poços tubulares e de análise de custos de explotação das águas subterrâneas, merecem destaque os seguintes trabalhos.

Perroni (2005) avaliou um elenco de 21 poços produtores dos sistemas de abastecimento público do município de São Carlos que explotavam o Sistema Aquífero Guarani e/ou o Aquífero Serra Geral. Através da aplicação da equação geral de cálculo de potencia consumida, o referido autor avaliou o rendimento dos sistemas de bombeamento em 
cada um dos poços e definiu estratégias e adequações com foco no aumento da eficiência. Para tanto, foi utilizado como indicador de eficiência o fator da relação de custo da energia elétrica consumida por volume unitário produzido $\left(\mathrm{R} \$ / \mathrm{m}^{3}\right)$, sendo denominado pelo autor de custo unitário de produção de água subterrânea. O autor utilizou o método de fixar o rendimento eletromecânico do sistema de bombeamento em $65 \%$ para determinar os ganhos financeiros com as reduções no consumo de energia.

Perroni e Wendland (2006) revisitaram os dados do trabalho citado acima e demonstraram que a eficiência energética variou de $\mathrm{R} \$ 0,10 / \mathrm{m}^{3}$ a $\mathrm{R} \$ 0,43 / \mathrm{m}^{3}$, com média de $\mathrm{R} \$ 0,17 / \mathrm{m}^{3}$, e o rendimento eletromecânico variou de $36 \%$ a $55 \%$, com média de $43 \%$, para um elenco de 16 poços de abastecimento público avaliados. Neste trabalho, também constataram a correlação inversa entre o rendimento do sistema e os valores de custo unitário de produção.

O método adotado pelos autores (PERRONI, 2005; PERRONI; WENDLAND, 2006) inspiraram algumas abordagens utilizadas no presente estudo. Muito embora, os cenários e as finalidades desses trabalhos serem bastante distintos do atual. A principal diferença está no elenco de dados disponíveis dos parâmetros de interesse para o cálculo do rendimento dos sistemas de bombeamento e da eficiência de produção. Nos trabalhos citados, os autores contaram com dados medidos do consumo e dos custos de energia elétrica e horas de operação dos sistemas. Nesta pesquisa, algumas aproximações e arbitragens foram necessárias para suprir a ausência de parâmetros de interesse.

Hirata (1993) teve enfoque na discussão das modernas exigências ambientais na proteção dos recursos hídricos subterrâneos, indicando a superexplotação como um dos problemas que afetam as disponibilidades hídricas subterrâneas. Dentre os efeitos negativos da superexplotação, destacados por Hirata (1993), estão: a diminuição no rendimento dos poços; e/ou grandes aumentos nos custos de bombeamento. O autor apresentou o caso da cidade de Lima, no Peru, retratando a diminuição da eficiência do consumo energético em poços, de 0,7 a $0,9 \mathrm{kWh} / \mathrm{m}^{3}$, em um período de 10 anos, provocada por rebaixamentos dos níveis potenciométricos de até 40, no mesmo período.

Também na temática sobre a estimativa de custos associados à superexplotação das águas subterrâneas, Reddy (2005) analisou uma região agrária na localidade de Andhra Pradesh, na Índia, constatando a ocorrência de externalidades associadas ao aumento de custos e perdas de poços de pequenos produtores, além de negativos efeitos ecológicos provocados pelos rebaixamentos dos níveis potenciométricos do aquífero. 
No estudo desenvolvido na Índia (REDDY, 2005), os custos de explotação foram calculados pela quantidade de poços perdidos (secos) e pelo aumento nos custos operacionais, determinando-se indicadores de produção de água por unidade de área irrigada. A partir desses indicadores, foram efetuadas comparações entre cenários existentes em duas regiões com diferentes modelos de desenvolvimento do uso da água subterrânea, diferenciando-se também os usuários de acordo com a renda familiar, nível de escolaridade, tamanho de propriedade, entre outros fatores sócio-econômicos. Os resultados apontaram a ocorrência de externalidades a todos os usuários das águas subterrâneas, no entanto, de forma bem mais acentuada aos pequenos produtores.

O método de cálculo das externalidades aplicado no trabalho de Reddy (2005) não pôde ser aplicado nesta pesquisa em decorrência das diferenças de contexto e, principalmente, pelos tipos de dados disponíveis em cada um dos trabalhos. Entretanto, demonstrou que a avaliação de externalidade deve ser customizada à realidade de cada cenário e, principalmente, que os critérios adotados possam demonstrar, além dos efeitos ambientais existentes, ou seja, que atingem a todos indistintamente, também os efeitos que atingem diferentemente distintos setores da sociedade.

No caso de São José do Rio Preto, por enquanto, não se justificou a setorização por classe social para a análise das externalidades causadas pelo intenso uso das águas subterrâneas. O enfoque principal foi a análise das externalidades provocada pelo cenário de explotação indistintamente da finalidade de uso ou perfil de usuário. Entretanto, foi plausível realizar a avaliação das externalidades sobre coletividade, provocada pelo uso particular dos recursos hídricos subterrâneos. 


\section{CARACTERIZAÇÃO DA ÁREA DE ESTUDO}

A área de estudo, com aproximadamente $728 \mathrm{~km}^{2}$, está localizada entre as coordenadas $20^{\circ} 55^{\prime}$ e $20^{\circ} 40^{\prime}$ de latitude e $49^{\circ} 15^{\prime}$ e $49^{\circ} 30^{\prime}$ de longitude, abrangendo praticamente a área total do município de São José do Rio Preto, o distrito de Engenheiro Schimidt e pequenas partes dos municípios de Mirassolândia, Ipiguá, Onda Verde, Guapiaçu, Cedral, Bady Bassitt, Mirassol e Bálsamo, situadas nos limites da área (Figura 3.1). Os limites da área são os mesmos estabelecidos no estudo do DAEE (2008), adotados para compatibilizar com a base de dados de poços disponibilizada para esta pesquisa.

O município de São José do Rio Preto possui área total de $434 \mathrm{~km}^{2}$ e perímetro urbano de $97 \mathrm{~km}^{2}$, situado na região noroeste do Estado de São Paulo, a $450 \mathrm{~km}$ da capital, pela rodovia Washington Luis (SP-310), e a 700 km de Brasília, pela Rodovia Transbrasiliana (BR-153). Doravante poderá ser referenciado por Rio Preto, como é localmente denominada a cidade ou pela sigla SJRP, visando facilitar a citação.
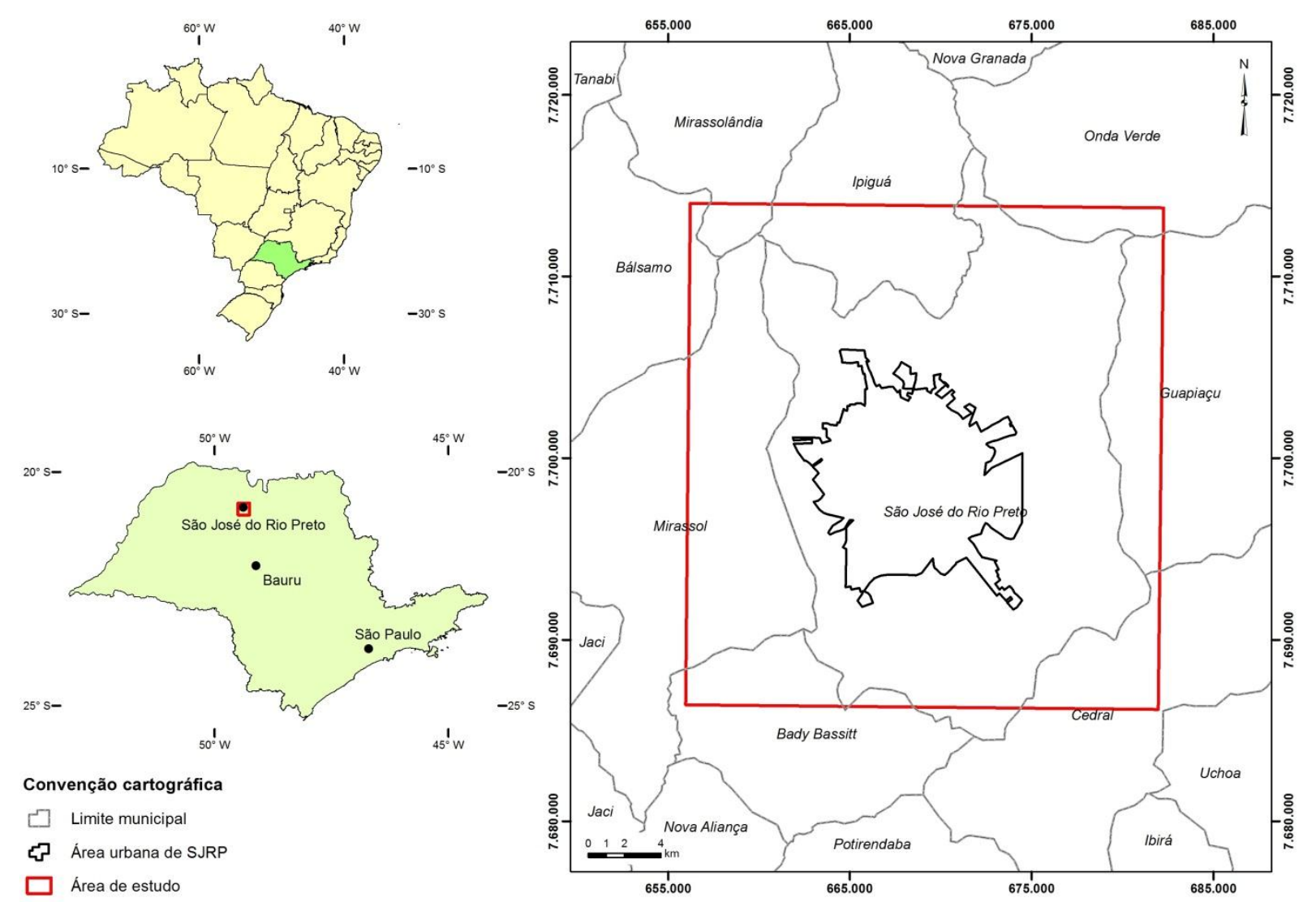

Figura 3.1 - Localização da área de estudo 


\subsection{ASPECTOS DEMOGRÁFICOS E DE OCUPAÇÃO TERRITORIAL}

A econômica regional é fortemente alicerçada na agricultura e pecuária, porém, SJRP teve seu desenvolvimento caracterizado pelo adensamento urbano, tornando-se um polo comercial regional por sua localização às margens de importantes eixos de transportes. Esse modelo de desenvolvimento levou à concentração da população na zona urbana com mais de 90\%, dos 406.220 habitantes (IBGE, 2010), residentes na sede municipal.

A taxa de crescimento na última década está abaixo de $2 \%$ ao ano, entretanto, São José do Rio Preto teve uma expansão populacional de 84.039 habitantes para 358.523 habitantes no período de 1960 a 2000. Esse crescimento, sobretudo nas décadas de 80 e 90 foi um dos fatores de pressão que levaram ao modelo de desenvolvimento do uso da água subterrânea.

O estudo foi desenvolvido considerando aproximadamente a área total do município, entretanto, é na zona urbana que se situa a grande concentração de poços, bem como outros fatores que influenciam fortemente a dinâmica das águas subterrâneas. Apesar de o estudo contemplar ambas as regiões, rural e urbana, serão enfatizados os aspectos relacionados à zona urbana do município, sobretudo, em decorrência da problemática abordada nesta pesquisa.

A ocupação urbana na área de estudo corresponde à sede municipal de SJRP, além de pequenos núcleos, tais como o Distrito de Engenheiro Schimidt, as cidades de Cedral e Bady Bassitt e uma pequena parte da cidade de Mirassol no oeste da área.

As principais atividades econômicas são a metalúrgica, madeira e mobiliário, as atividades de serviços e de comércio, além da construção civil (PMSJRP, 2010), distribuídas nas áreas de ocupação mista da sede e, principalmente, instaladas em 3 distritos industriais e 13 minidistritos. A agricultura ainda possuir um importante papel na economia do município, atualmente com predominância à produção cana de açúcar, seguido de milho e sorgo (PMSJRP, 2010).

O mapeamento do uso e ocupação do solo realizado pelo DAEE (2008), demonstrado na Figura 3.2, identifica uma ocupação predominantemente residencial, seguida de ocupação mista residencial e comercial e zonas localizadas tipicamente industriais.

A concentração populacional na sede municipal apresenta adensamento médio de $7,0 \times 10^{3} \mathrm{hab} / \mathrm{km}^{2}$ nas regiões central e noroeste, situadas a oeste da margem esquerda do rio Preto e densidade demográfica média de aproximadamente $2,5 \times 10^{3} \mathrm{hab} / \mathrm{km}^{2}$ nas demais regiões da cidade (PMSJRP, 2010). 


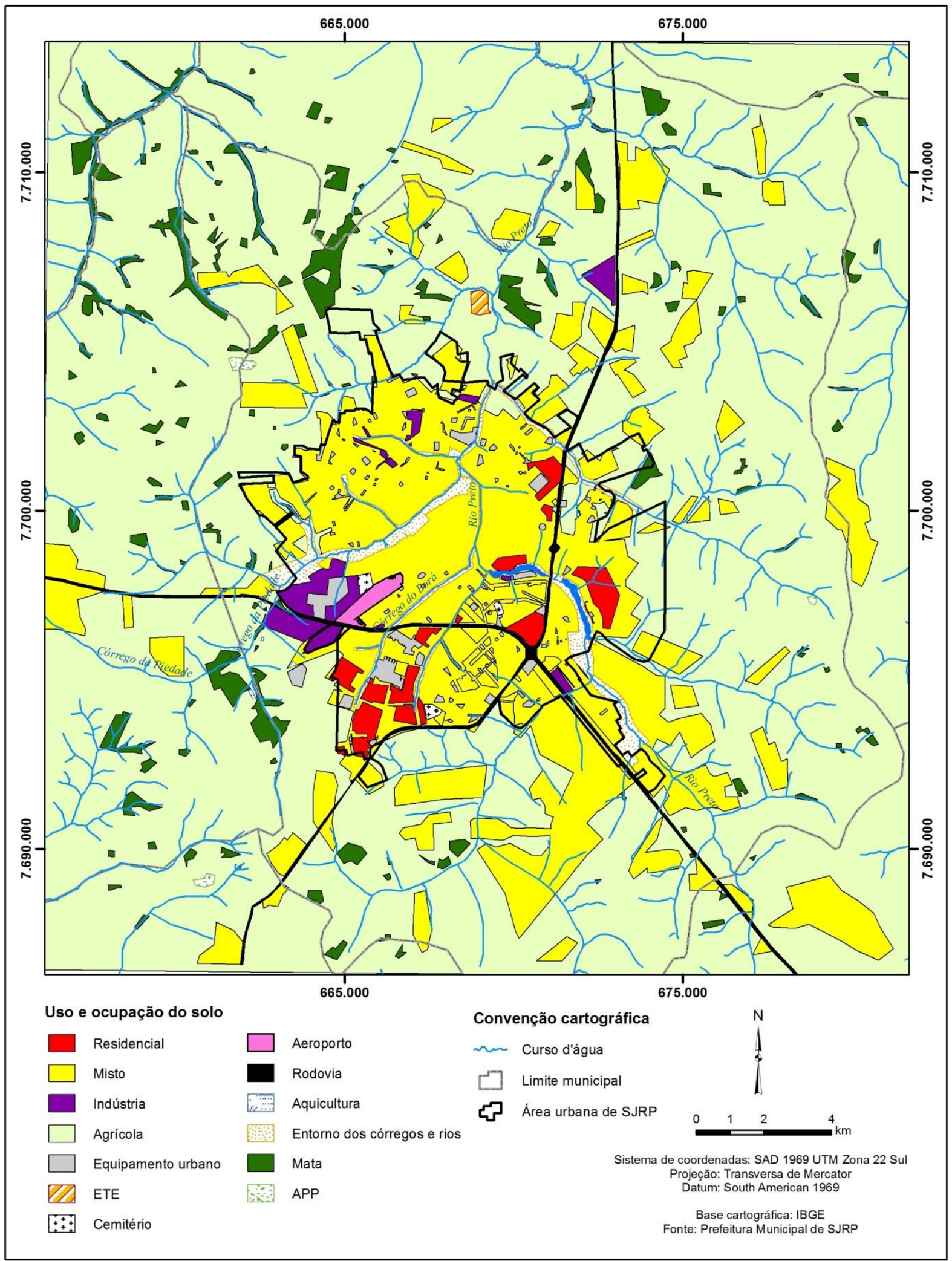

Figura 3.2 - Mapa de uso e ocupação do solo na área de estudo (DAEE, 2008) 
A cidade conta com dois lagos artificiais (represas), de aproximadamente $1 \mathrm{~km}$ de extensão cada, situados na parte centro-leste do perímetro urbano, sendo que o lago de montante é responsável pelo fornecimento de $26 \%$ da água distribuída pelo Semae.

A área rural é extensamente utilizada para as práticas agrícolas, com destaque às culturas de cana de açúcar, milho, laranja e pastagens para a pecuária bovina. No mapa da Figura 3.2, também se observa a ocorrência de pequenos e isolados núcleos de mata, em grande parte, áreas de preservação permanentes e áreas de reserva legal, demonstrando o elevado índice de desmatamento, mesmo nas APP de matas ciliares.

\subsection{ASPECTOS FISIOCLIMÁTICOS}

A área de estudo está inserida na província geomorfológica do Planalto Ocidental Paulista (ALMEIDA, 1964; IPT, 1981b), localmente caracterizada por relevo ondulado, relativamente uniforme com extensos e baixos espigões em faixas longas e estreitas, principalmente nos divisores de água (BARCHA, 1980).

O relevo desta província mostra condicionamento estrutural controlado pelas camadas sub-horizontais, com leve caimento para oeste, formando uma extensa plataforma estrutural extremamente suavizada, com altimetria variando entre 400 e $700 \mathrm{~m}$ e as declividades médias predominantes das vertentes estão entre 2 e 10\% (IPT, 1981b), apresentando formas de colinas amplas e colinas médias (IPT, 2006).

As colinas médias ocorrem principalmente nas cabeceiras e nos interflúvios das principais drenagens das bacias hidrográficas dos rios Preto e Turvo e as colinas amplas ocupam quase a totalidade das áreas drenadas para o Rio Grande (IPT, 2006).

Nos relevos das colinas amplas predominam interflúvios com área superior a $4 \mathrm{~km}^{2}$, topos extensos e aplainados, e vertentes com perfis retilíneos a convexos. Geralmente a drenagem é de baixa densidade e apresenta padrão subdendrítico. Os vales são abertos com a presença de planícies aluviais interiores restritas, podendo ocorrer lagoas perenes ou intermitentes (IPT, 2006).

Nas áreas com relevo de colinas médias predominam interflúvios com áreas de 1 a 4 $\mathrm{km}^{2}$, de topos aplainados, drenagem de média a baixa densidade. As formas revelam que os entalhamentos médios dos vales são inferiores a $20 \mathrm{~m}$ e as extensões interfluviais médias 
estão em torno de $2.000 \mathrm{~m}$. As altimetrias variam entre 400 e $700 \mathrm{~m}$ e as declividades médias predominantes das vertentes estão entre 2 e $10 \%$ (IPT, 2006).

O município de São José do Rio Preto está inserido na Sub Bacia do Rio Preto (Sub Bacia 7) pertencente à bacia hidrográfica dos rios Turvo e Grande. A Figura 3.3 mostra a sub bacia do rio Preto no contexto da Unidade Hidrográfica de Gerenciamento de Recursos Hídricos 15 (UGRHI - 15), Bacia Hidrográfica do Turvo/Grande (BH-TG).

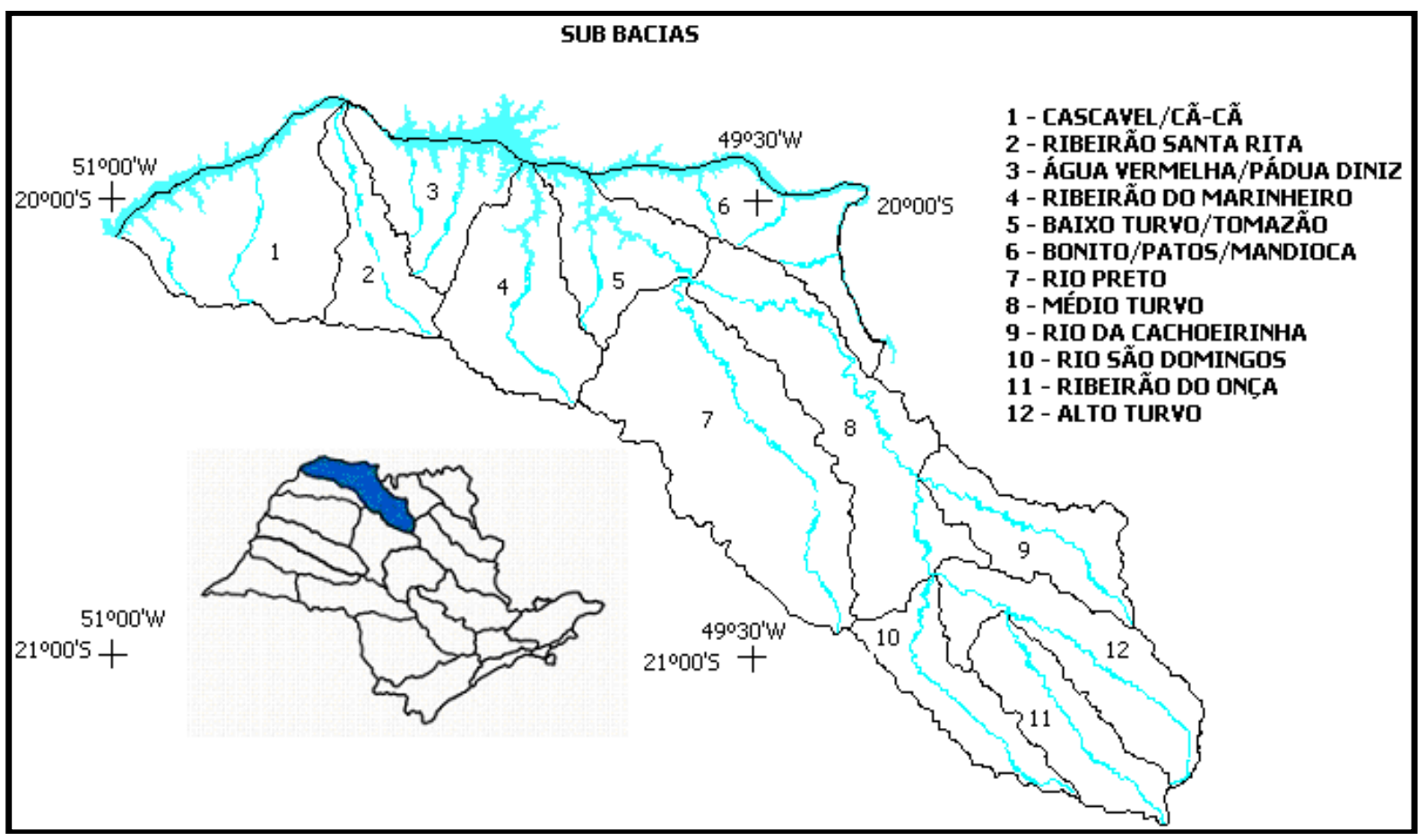

Figura 3.3 - Bacia Hidrográfica do Rio Turvo/Grande e as Sub Bacias (IPT, 1999)

A UGRHI 15 possui $15.975 \mathrm{~km}^{2}$, sendo definida pela Bacia do Rio Turvo e seus tributários, e pelas porções drenadas diretamente para o Rio Grande, fazendo limite a norte pelo Estado de Minas Gerais pelo rio Grande, a leste pela Bacia do Baixo Pardo/Grande, a sudeste pela Bacia do Rio Mogi Guaçu, e ao sul pelas bacias Tietê/Batalha e São José dos Dourados (IPT, 1999).

Alguns afluentes do Rio Preto identificados na área de estudos são os córregos dos Macacos, da Boa Esperança, da Lagoa, Canela, do Moraes, Borá, Piedade, da Felicidade, da Mistura, São Pedro, do Barreiro, do Talhado, Talhadinho e da Estiva. Devem-se destacar os córregos Borá, Canela e Piedade, todos afluentes da margem esquerda do rio Preto e que estão inseridos na zona urbana, em grande extensão, canalizados e situados sob ou à margem de importantes avenidas. 
O rio Preto adentra a zona urbana pela região sudeste e, a partir da área central da cidade, seguem em direção ao norte. Nesse percurso na zona urbana, o rio Preto possui cerca de $15 \mathrm{~km}$ de extensão e dois barramentos que formam lagos artificiais, situados na região centro-leste da cidade.

O clima que predomina em $60 \%$ da área do município é o tropical úmido com inverno seco (Aw) e, na sua parte sul, o subtropical (Cwa) (IPT, 1999). A temperatura média anual observada entre 1994 e 2006 foi de $25^{\circ} \mathrm{C}$. As temperaturas média-máxima e média-mínima foram de $31^{\circ} \mathrm{C}$ e $19^{\circ} \mathrm{C}$, respectivamente. A menor temperatura já registrada foi $0,5^{\circ} \mathrm{C}$, em julho de 2000, e a maior da série histórica foi de $42^{\circ} \mathrm{C}$, em outubro de 2002 (DAEE, 2008).

Os dados de precipitação consultados foram da estação pluviométrica do DAEE (B6020), localizada em São José do Rio Preto, obtidos entre 1941 e 2004. Os índices pluviométricos médios mensais variaram entre o mínimo de $17 \mathrm{~mm}$ e $239 \mathrm{~mm}$ no período mais chuvoso. As médias mínimas variaram entre $0 \mathrm{~mm}$ e $31 \mathrm{~mm}$ e as medias máximas entre $111 \mathrm{~mm}$ e $537 \mathrm{~mm}$. Desconsiderando os períodos com poucos dados, calculou-se a precipitação anual (média) de $1.220 \mathrm{~mm}$.

\subsection{GEOLOGIA}

A área de estudo está inserida, regionalmente, na unidade geológica da bacia intracratônica do Paraná, que é caracterizada por sequências sedimentares que se depositaram a partir do Devoniano Superior/Siluriano intercaladas por importante episódio vulcanogênico, no Cretáceo Inferior, responsável pela geração dos derrames basálticos da Formação Serra Geral (IPT, 1981a), e que constituem o embasamento da sequência sedimentar do Grupo Bauru (SOARES et al., 1980), aflorante na área de estudo.

As rochas do Grupo Bauru cobrem 47\% do Estado de São Paulo, correspondendo a $117.000 \mathrm{~km}^{2}$ (Figura 3.4), de uma área total de ocorrência de cerca de $370.000 \mathrm{~km}^{2}$, abrangendo também parte dos estados de Minas Gerais, Paraná, Goiás e Mato Grosso do Sul (PAULA E SILVA, 2003). Os sedimentos dessa unidade foram depositados no Cretáceo Superior, por evento de compensação isostática posterior ao acúmulo de quase $2.000 \mathrm{~m}$ de derrames basálticos da Formação Serra Geral, ocorridos no Cretáceo Inferior e que constituem o embasamento dos depósitos do Grupo Bauru, separados por desconformidade erosiva regional (FERNANDES; COIMBRA, 1996). 


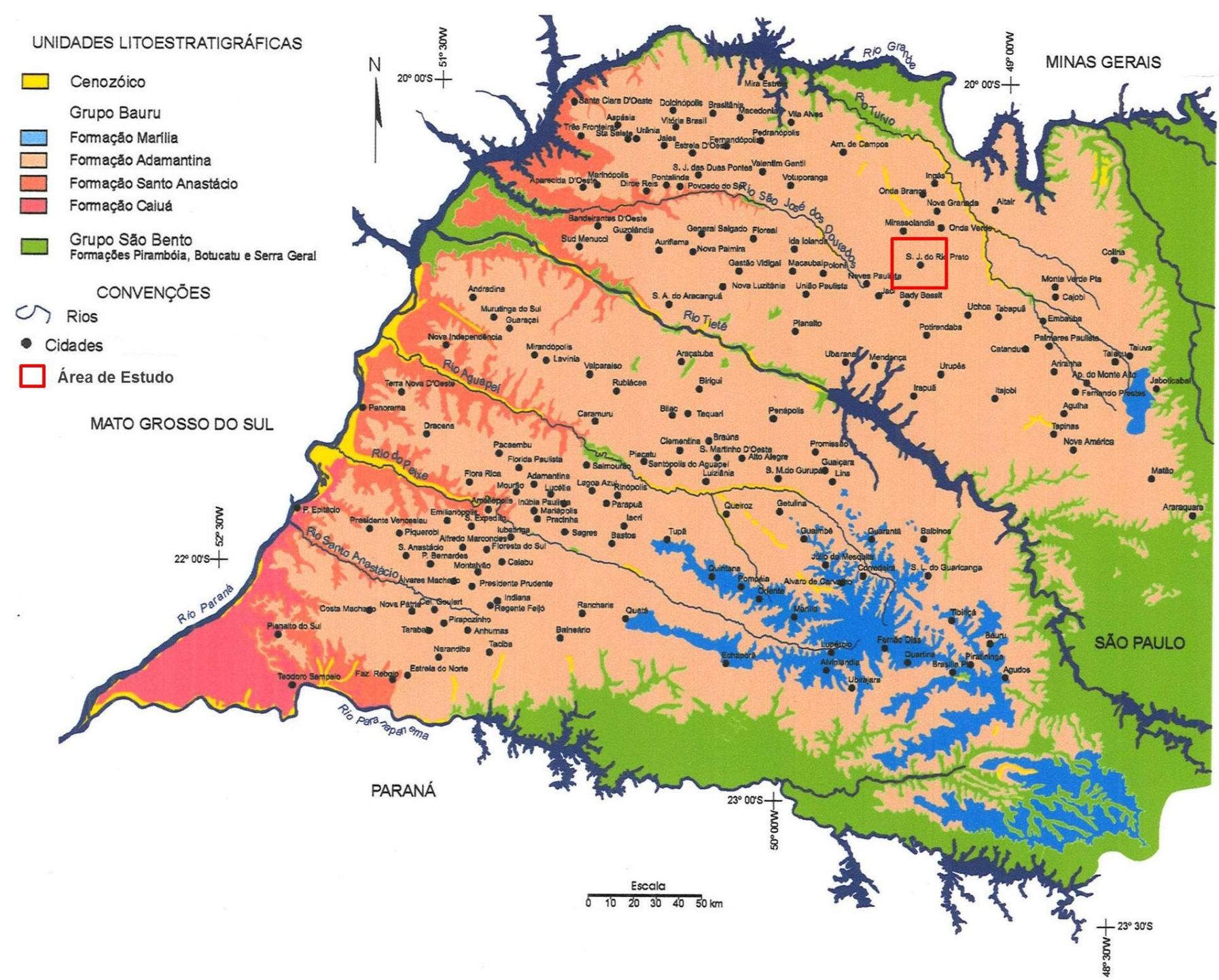

Figura 3.4 - Mapa geológico do Grupo Bauru no Estado de São Paulo (modificado de Paula e Silva, 2003) 
As rochas do Grupo Bauru são predominantemente constituídas por sedimentos siliciclásticos continentais, depositados em ambientes áridos e semi-áridos, com espessuras médias entre 100 e $200 \mathrm{~m}$, podendo atingir até $320 \mathrm{~m}$ (FERNANDES, 1998). Litologicamente, a sequência é caracterizada por arenitos, arenitos argilosos, carbonatados ou não, siltitos, lamitos, argilitos e ocorrências localizadas de conglomerados (DAEE, 1976).

A estratigrafia do Grupo Bauru, apesar de intensamente estudada, ainda não alcançou o consenso da comunidade científica. Basicamente, existem duas versões de divisão estratigráfica, de acordo com as propostas de Soares et al. (1980) e a de Fernandes (1998) (PAULA E SILVA, 2003). As divergências nas subdivisões estratigráficas estão refletidas também na área desta pesquisa, conforme será discutido adiante.

Fernandes (1998) baseou-se na análise litoestratigráfica em conjunto com a gênese de bacias, alcançando um modelo de fácies cronocorrelatas que culminou com a subdivisão da sequência sedimentar neocretácea (terminologia adotada pelo citado autor), em dois grupos: Grupo Caiuá (formações Rio Paraná, Goio Erê e Santo Anastácio) e Grupo Bauru (formações Uberaba, Vale do Rio do Peixe, Araçatuba, São José do Rio Preto, Presidente Prudente e Marília). Os dois grupos apresentam passagem gradual, lateral e recorrente a quase toda sequência deposicional. Esta subdivisão estratigráfica evoluiu de estudos anteriores (FERNANDES, 1992; FERNANDES; COIMBRA, 1994) e foi ratificada em trabalhos posteriores como, por exemplo, por Fernandes e Coimbra (2000).

Segundo a proposta de Fernandes (1998), a sequência estratigráfica do Grupo Bauru, na área deste estudo, é caracterizada pela Formação São José do Rio Preto (aflorante), sobreposta à Formação Vale do Rio do Peixe, podendo ocorrer passagem lateral e interdigitação com a Formação Araçatuba, na porção basal da sequência próxima ao limite com o embasamento, dado pelos derrames basálticos da Formação Serra Geral.

Fernandes e Coimbra (2000) discutiram sobre as limitações conceituais associadas às definições da aloestratigrafia de sequências continentais e as limitações formais do Código Brasileiro de Nomenclatura Estratigráfica em vigência, na aplicação do modelo de sequência estratigráfica defendido pelos referidos autores. Tais limitações e a inovação da citada versão, diante às clássicas definições utilizadas por inúmeros outros autores, com destaque a Soares et al. (1980), provocam uma menor aceitação à proposta de Fernandes (1998).

Soares et al. (1980) basearam-se na compilação de diversos trabalhos de mapeamento regional e propuseram a elevação da sequência suprabasáltica cretácea Bauru para Grupo, subdividido nas formações Caiuá, Santo Anastácio, Adamantina e Marília. Esta se tornou a clássica subdivisão do Grupo Bauru, aceita pela maioria dos geocientistas, a partir da qual, 
inúmeros pesquisadores dedicaram-se às revisões estratigráficas e aos trabalhos de reconhecimento e extensão para outras áreas (PAULA E SILVA, 2003).

No contexto de revisões estratigráficas do Grupo Bauru, merece destaque o trabalho de Barcelos e Suguio (1987) que correlacionaram e estenderam as unidades litoestratigráficas definidas em São Paulo por Soares et al. (1980) para os estados de Minas Gerais, Mato Grosso do Sul, Goiás e Paraná, sugerindo também a subdivisão da Formação Adamantina nos membros Araçatuba e São José do Rio Preto. Posteriormente, Batezelli et al. (1999) redefiniram e caracterizaram a extensão da ocorrência da Formação Araçatuba, incluindo-a sequência estratigráfica neocretácea sotoposta aos basaltos da Formação Serra Geral e com interdigitação lateral e cronocorrelação com a Formação Adamantina.

Paula e Silva et al. (2003) destacaram trabalhos de correlação estratigráfica de subsuperfície do Grupo Bauru, realizados a partir de dados de perfurações e perfilagens geofísicas de poços produtores de água subterrânea e estabeleceram correlações estratigráficas das formações do Grupo Bauru, em quatro regiões no Estado de São Paulo, conforme demonstrado na Figura 3.5.

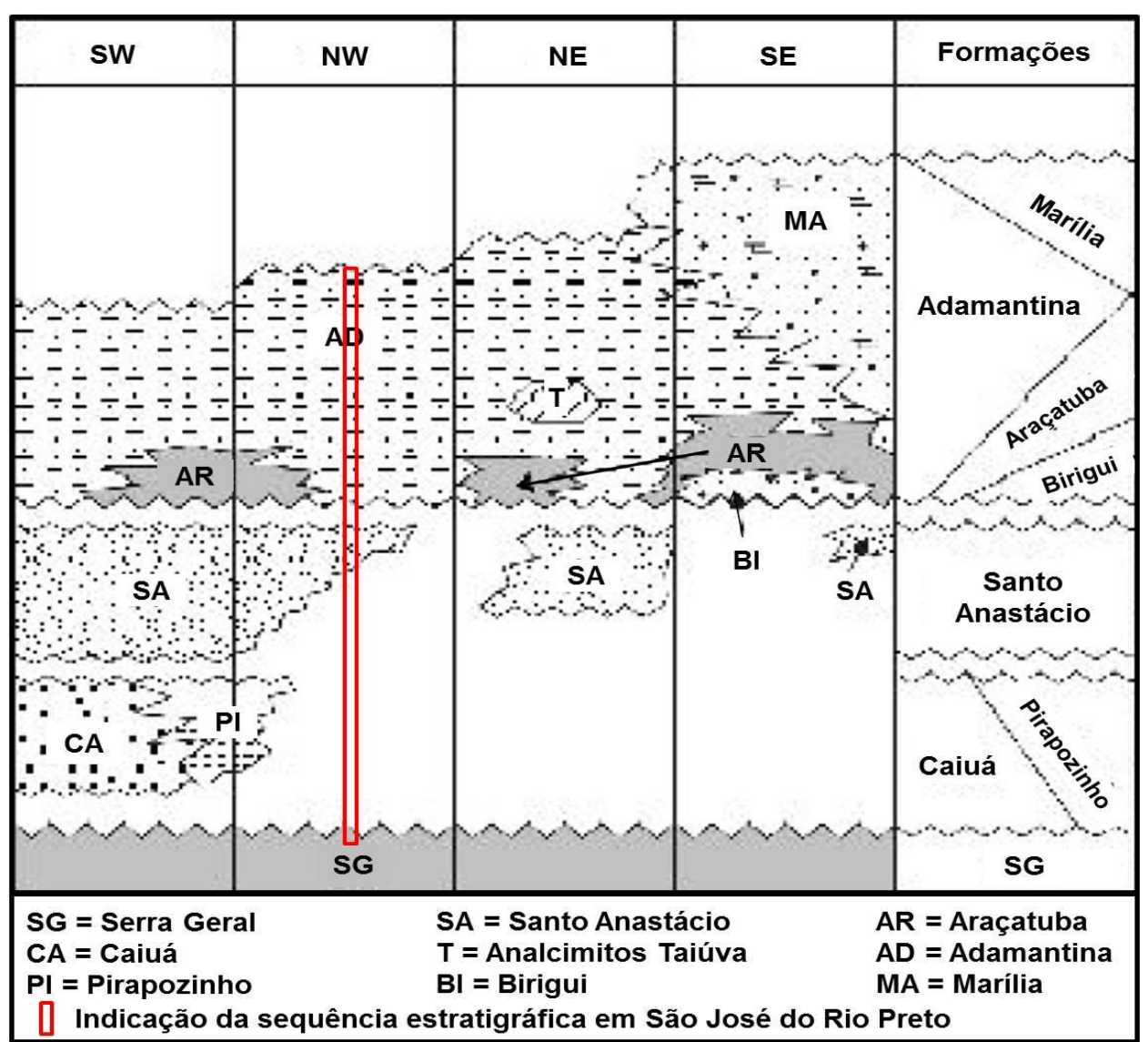

Figura 3.5 - Relações estratigráficas das formações do Grupo Bauru no Estado de São Paulo com destaque à sequência estratigráfica em SJRP (adaptado de Paula e Silva et al., 2003) 
Na região de interesse deste estudo, destaca-se o trabalho de Paula e Silva et al. (2002) que, a partir da correlação de perfis geofísicos calibrados de poços perfurados para a captação de águas subterrâneas com as formações definidas por Soares et al. (1980) e Batezelli (1999), reconheceram a sequência estratigráfica da Formação Adamantina, sobreposta à Formação Santo Anastácio, separadas por desconformidade do embasamento constituído pelos derrames basáltico da Formação Serra Geral, conforme demonstrado no destaque da Figura 3.5. O referido trabalho sugere a existência de um hiato temporal (discordância) entre as formações Adamantina e Santo Anastácio nesta região, dado pela brusca alteração dos perfis geofísicos analisados.

$\mathrm{O}$ atual estudo adota para a área de interesse a sequência estratigráfica reconhecida por Paula e Silva et al. (2002), baseada na versão clássica de Soares et al. (1980). Esta decisão também está alicerçada na versão adotada na base de dados de poços utilizada nesta pesquisa (DAEE, 2008), nos casos em que as informações sobre os perfis litológicos são disponíveis.

Litologicamente, a Formação Adamantina é composta por arenitos de granulação fina a muito fina, coloração rósea a castanha, com estratificação cruzada, alternados com bancos de lamitos, siltitos e arenitos lamíticos, de cor castanho-avermelhado a cinza-castanho, maciços ou com acamamento plano-paralelo grosseiro, frequentemente com marcas de onda a microestratificação cruzada (IPT, 1981a) e a Formação Santo Anastácio é constituída por arenitos marrom-avermelhados a arroxeados, de granulação fina a média, mal selecionado, com grãos arredondados a subarredondados, cobertos por película limonítica (PAULA E SILVA et al., 2002; LIMA, 2004).

Os dados disponíveis no cadastro de poços do DAEE (2008) contendo informações sobre o perfil litológico com elevada confiabilidade permitiram a elaboração do mapa de espessura do pacote sedimentar (Figura 3.6), bem como a análise estatística das espessuras das unidades sedimentares suprabasálticas.

A partir de dados de 41 poços, contendo informações relativas ao perfil litológico da perfuração, avaliou-se que a espessura do pacote sedimentar da Formação Adamantina, na área de estudo, varia de 71 a 150 m, com média de 108 m e mediana de 104 m. A Formação Santo Anastácio, analisada a partir de dados de perfis de 20 poços, apresenta espessura variando de 24 a $68 \mathrm{~m}$, com média de $44 \mathrm{~m}$ e mediana de $43 \mathrm{~m}$. 


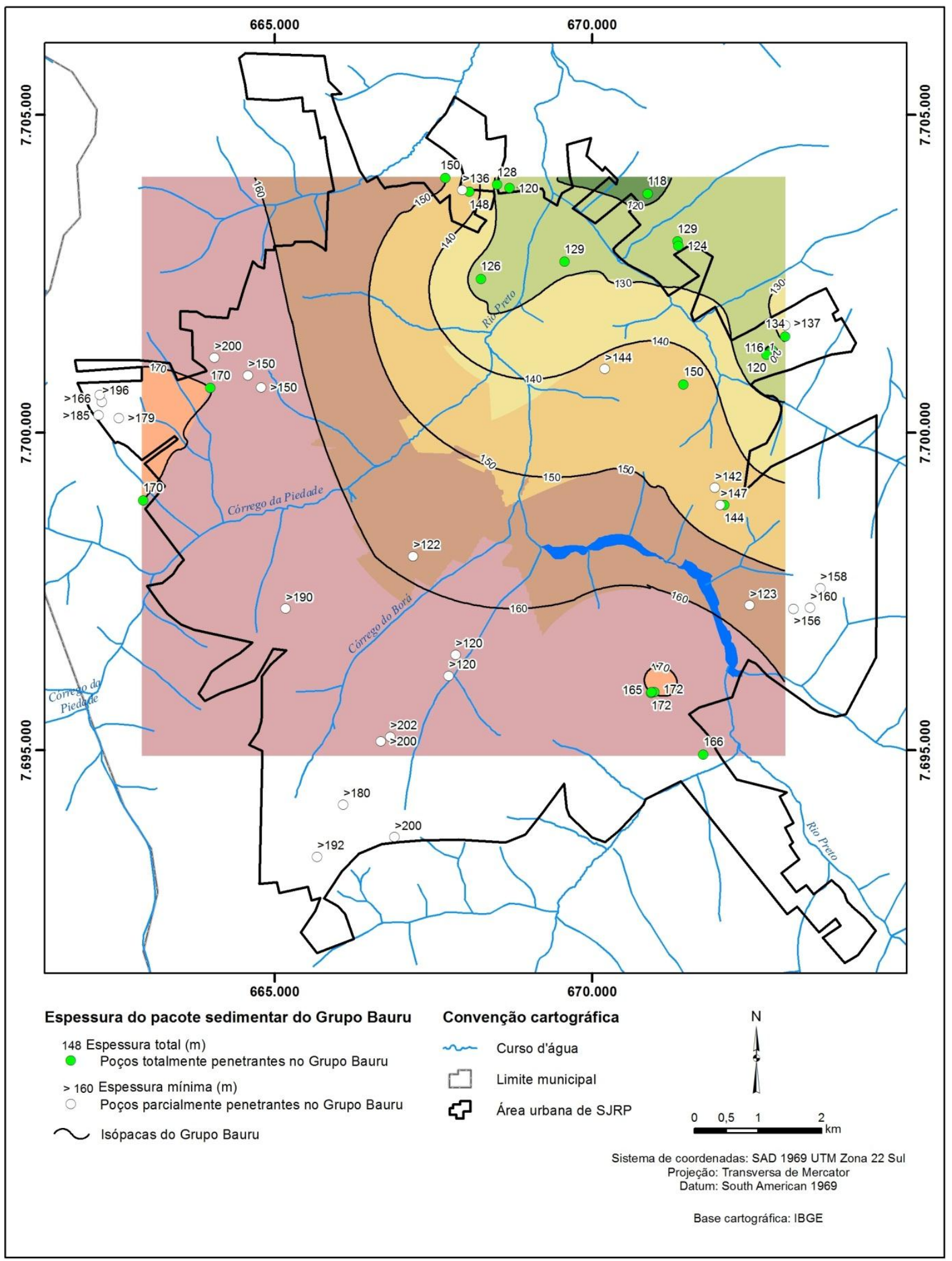

Figura 3.6 - Mapa de isópacas do Grupo Bauru em São José do Rio Preto 
A espessura total da sequência sedimentar neocretácea na área de estudo varia de 116 a $172 \mathrm{~m}$, com espessura média de $143 \mathrm{~m}$ e mediana de $139 \mathrm{~m}$, conforme dados dos poços totalmente penetrantes no pacote sedimentar. Estes valores são compatíveis com estudos

anteriores já realizados na região como, por exemplo, as espessuras indicadas por Barcha (1980) para poços em SJRP que variavam de 108 a 197 m e média de 142 m, no perfil geofísico e litológico avaliado por Paula e Silva et al (2002) com $150 \mathrm{~m}$ de sequência sedimentar e na estatística demonstrada por Lima (2004) com dados de 28 poços que apresentavam espessuras variando de 102 a 200 m, média de 143 m e mediana de $140 \mathrm{~m}$.

A espessura do pacote sedimentar está condicionada tanto pela morfologia do relevo atual quanto pela superfície dos derrames basáltico subjacentes ao Grupo Bauru. A variação altimétrica do topo dos derrames está associada à morfologia da superfície erosiva que caracteriza o contato discordante com os pacotes sedimentares cretáceos, sendo que, em muitos casos o paleorelevo dos basaltos foi condicionado por estruturas tectônicas, evidenciado por significativos desníveis na profundidade do basalto (BARCHA, 1980).

As cotas topográficas dos basaltos da Formação Serra Geral, na área de estudo, variam de 324 a 393 m, com valor médio de 367 m, de acordo com os dados disponíveis em 15 poços do cadastro disponibilizado pelo DAEE (2008). Estas cotas dos basaltos são compatíveis com os descritos por Barcha (1980), em 16 poços, que variavam de 334 a 382 m com valor médio de 355 m e por Lima (2004), em 28 poços, que apresentou valores variando de 303 a 433 m, com média de $362 \mathrm{~m}$.

\subsection{HIDROGEOLOGIA}

A região oeste do Estado de São Paulo é, sob o aspecto hidrogeológico, naturalmente beneficiada. Regionalmente, três importantes unidades aquíferas estão presentes, sendo: o Sistema Aquífero Bauru, o Aquífero Serra Geral e o Sistema Aquífero Guarani. Essa característica favorece que as águas subterrâneas sejam priorizadas como fonte de abastecimento para o consumo de água. No Estado, mais de $70 \%$ dos municípios são abastecidos, total ou parcialmente, por água subterrânea (CETESB, 2007) e, se considerar somente a região oeste paulista, na área de abrangência dos citados aquíferos, esse percentual se eleva acima dos $90 \%$. 
A importância de estudar a hidrogeologia e discutir a gestão dos citados aquíferos é inquestionável. Entretanto, esta pesquisa se propõe a avaliar o cenário de uso das águas subterrâneas do Sistema Aquífero Bauru em São José do Rio Preto, sendo que se apresenta exclusivamente a caracterização desse sistema hidrogeológico.

No início da década de 80, o interesse hidrogeológico e o início da intensa explotação do Sistema Aquífero Bauru (SAB), levaram diversos especialistas (BARCHA, 1980; ROCHA et al., 1981; MEZZALIRA, 1981) e o poder público, principalmente o DAEE (SÃO PAULO, $1974^{1}, 1976^{2}, 1979^{3}$ apud ROCHA et al., 1981), a estudarem essa unidade hidrogeológica. Naquela ocasião eram estimados cerca de 4.000 poços explotando o SAB em toda a sua extensão no Estado de São Paulo (ROCHA et al., 1981), sendo que, atualmente, somente em São José do Rio Preto estão cadastrados cerca de 2.000 poços (DAEE, 2008). Segundo o Plano Estadual de Recursos Hídricos (SÃO PAULO, 2006), são estimados cerca de 30.000 poços em todo o Estado, permitindo inferir com razoável segurança que próximo de 50\% deste montante explotam o SAB.

Rocha et al. (1981) elencaram alguns fatores que deflagraram o potencial hidrogeológico do $\mathrm{SAB}$, aqui ratificados e complementados, com destaque a: facilidade de captação das águas subterrâneas por meio de poços de profundidade moderada; grande extensão de ocorrência com elevada demanda hídrica, abrangendo inúmeras sedes urbanas do interior paulista e áreas de intensa produção agroindustrial; obtenção de água a baixo custo, tanto na construção e manutenção de poços de captação quanto na explotação das águas subterrâneas; possibilidade de sistemas de abastecimento público modulares com baixo custo de implantação devido à proximidade da fonte de água com o mercado consumidor; e, elevada qualidade das águas, em geral, dispensando tratamento ou, no caso do abastecimento público, recebendo apenas cloração.

O Sistema Aquífero Bauru é constituído pelas rochas sedimentares do Grupo Bauru e, desse modo, ocorre aflorante em todo setor oeste do Estado de São Paulo (Figura 3.7), cujos limites são: a oeste e noroeste o rio Paraná, a norte o rio Grande, a sul o rio Paranapanema e as áreas de afloramento dos basaltos da Formação Serra Geral que também constituem os limites leste e basal do SAB (SÃO PAULO, 2005).

\footnotetext{
${ }^{1}$ SÃO PAULO. Departamento de Águas e Energia Elétrica. Estudo de águas subterrâneas - Região Administrativa 6 - Ribeirão Preto. São Paulo: DAEE, 1974. 4 v.

${ }^{2}$ SÃO PAULO. Departamento de Águas e Energia Elétrica. Estudo de Águas Subterrâneas - Regiões Administrativas 7, 8, 9 - Bauru, São José do Rio Preto, Araçatuba. São Paulo: DAEE, 1976. v. 1 e 2.

${ }^{3}$ SÃO PAULO. Departamento de Águas e Energia Elétrica. Estudo de Águas Subterrâneas - Regiões Administrativas 10 e 11 - Presidente Prudente e Marilia. São Paulo: DAEE, 1979. v.1 e 2.
} 


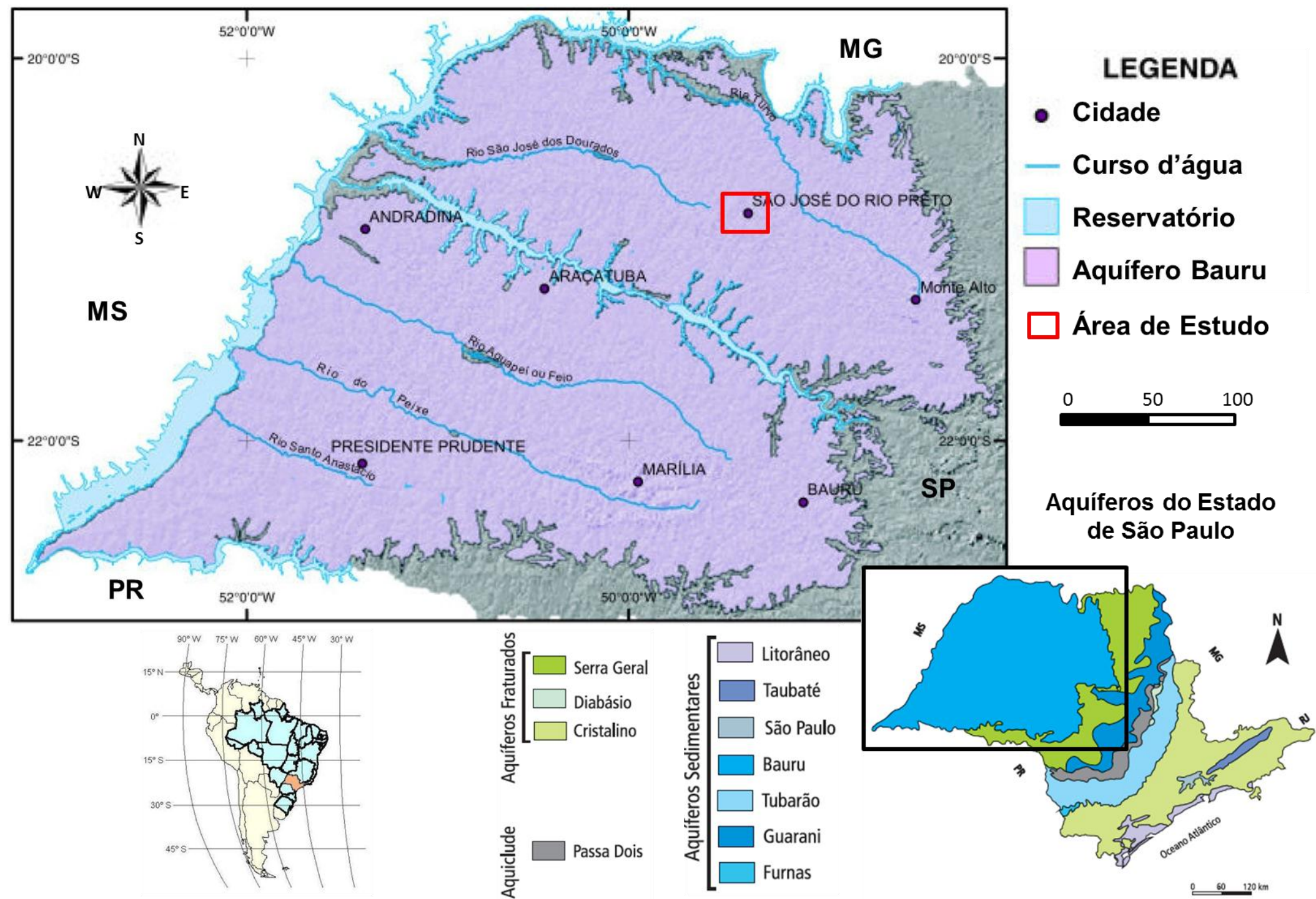

Figura 3.7 - Área de abrangência do Sistema Aquífero Bauru no Estado de São Paulo com a indicação esquemática simplificada do mapa de aquíferos do Estado (adaptado de SÃO PAULO, 2005; IRITANI; EZAKI, 2009) 
As unidades litoestratigráficas que compõem o Grupo Bauru são predominantemente constituídas por sedimentos siliclásticos com elevada diversidade faciológica que influenciam as características hidráulicas do $\mathrm{SAB}$, provocando um comportamento hidrogeológico muito variável, principalmente condicionado por diversos fatores físicos, tais como: litologia, porosidade, permeabilidade e cimentação (MEZZALIRA, 1981). Existem evidências que estruturas tectônicas também influenciam na variação dos parâmetros hidráulicos do SAB (SÃO PAULO, 2005).

O comportamento hidrogeológico variável levaram alguns pesquisadores a proporem compartimentações do SAB. Barcha (1980) compartimentou sua área de estudo, na região noroeste do $\mathrm{SAB}$, em três áreas distintas, a partir das características litológicas e hidrogeológicas avaliadas. Rocha et al. (1981) sugeriram a subdivisão do SAB em duas unidades aquíferas, baseada na correlação entre litoestratigrafia e o comportamento hidráulico, sendo uma constituída pelas formações Marília e Adamantina e a outra pelas formações Santo Anastácio e Caiuá, conforme proposta estratigráfica do Grupo Bauru definida por Soares et al. (1980). Uma abordagem semelhante à utilizada por Rocha et al. (1981) foi adotada na elaboração do mapa de águas subterrâneas do Estado de São Paulo (SÃO PAULO, 2005), porém correlacionando às unidades litoestratigráficas propostas por Fernandes (1992).

Devido às características do arcabouço litológico, o SAB é: tipicamente poroso; apresenta, de maneira geral, conectividade hidráulica entre as unidades que constituem a sequência sedimentar; possui, regionalmente, comportamento livre e, localmente, semiconfinado ou confinado; com recarga natural dada diretamente pelas chuvas precipitadas sobre sua extensa área de afloramento (SÃO PAULO, 2005; IRITANI; EZAKI, 2009). Essas características conferem ao SAB favorável potencialidade hídrica em toda sua extensão, sendo estimada uma reserva explotável total de $130 \mathrm{~m}^{3} / \mathrm{s}$ (CAMPOS et al., 2000) na sua área de ocorrência no Estado de São Paulo. Ressalta-se, entretanto, que tal potencialidade ocorre de maneira bastante heterogênea, conforme já discutido, bem como demonstrado pelos parâmetros hidráulicos que serão apresentados adiante.

Os níveis de água são relativamente rasos, acompanhando o relevo, com espessura saturada média de $75 \mathrm{~m}$, podendo variar em função da morfologia da superfície do terreno e pela estruturação do substrato basáltico, alcançando espessura saturada máxima da ordem de 300 m (SÃO PAULO, 2005). Barcha (1980) encontrou forte correlação entre a espessura saturada do $\mathrm{SAB}$ e a produtividades dos poços. 
O fluxo subterrâneo do $\mathrm{SAB}$, conforme observado nas equipotenciais que se alongam coincidentemente aos cursos das drenagens (Figura 3.8), acompanhando a morfologia do relevo, demonstra o comportamento de aquífero livre, evidenciando que as regiões topograficamente elevadas atuam como áreas de recarga, a partir das quais migram os fluxos subterrâneos em direção às drenagens efluentes que são alimentadas pelas águas subterrâneas do SAB e, desse modo, constituem as áreas de descarga desse sistema hidrogeológico (CAMPOS et al., 2000).

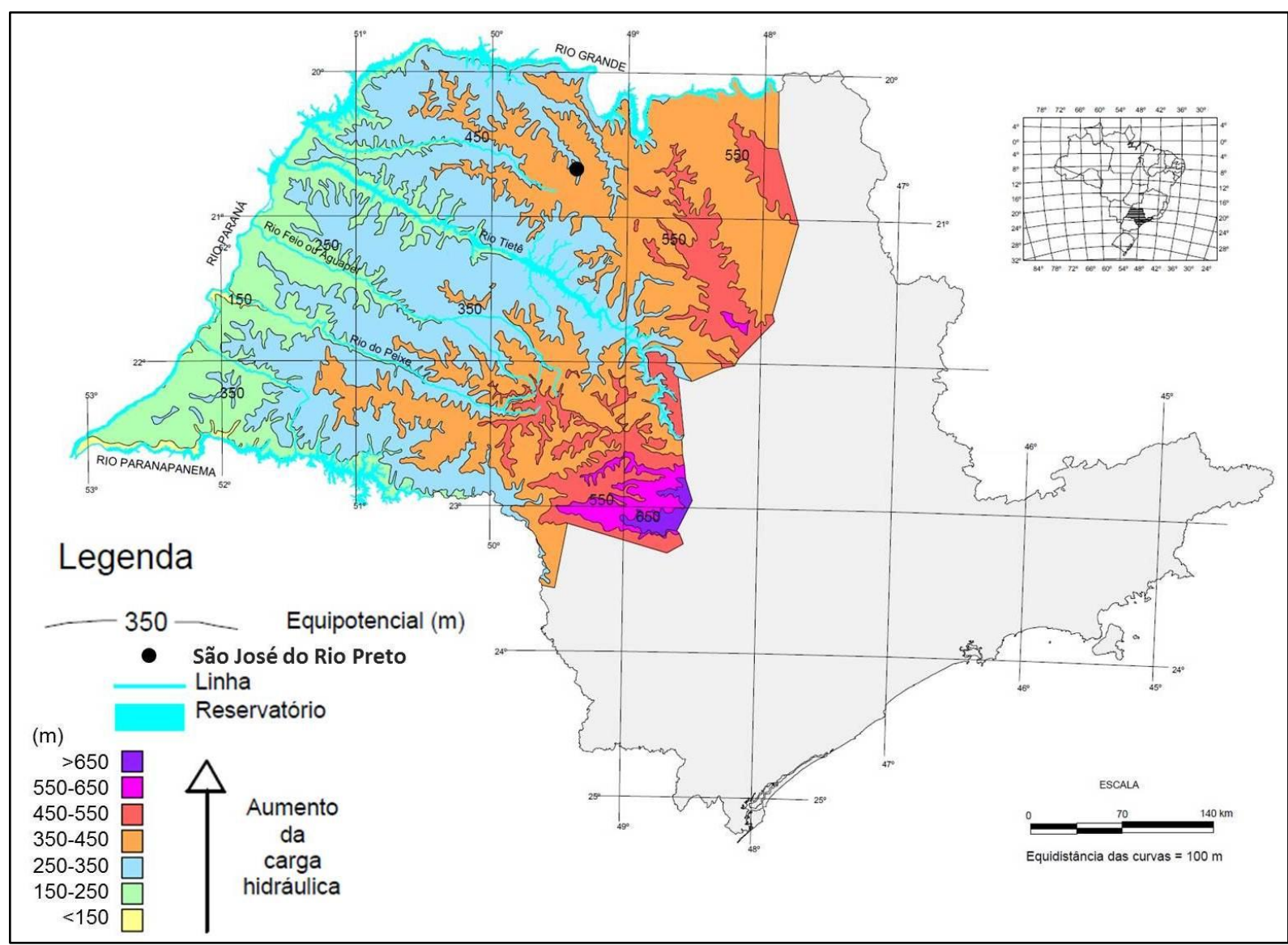

Figura 3.8 - Mapa potenciométrico do Sistema Aquífero Bauru (modificado de CAMPOS et al., 2000)

Em escala de detalhe, o comportamento regional se repete, entretanto, com fluxos subterrâneos mais rasos e de menor tempo trânsito alimentando as drenagens das microbacias hidrográficas (córregos e riachos) e fluxos mais profundos e com maior tempo de trânsito, descarregando nos principais rios das bacias hidrográficas instaladas nos terrenos do Grupo Bauru. Barcha (1997) descreveu esse comportamento no setor noroeste do SAB que abrange a área deste estudo, caracterizando a ocorrência de circulação subterrânea mais próxima à superfície, vinda dos interflúvios para os vales dos rios e córregos e, em profundidade, fluxo regional na direção N-NE para S-SW. 
Os parâmetros hidráulicos do $\mathrm{SAB}$, conforme já discutido, são influenciados pelas heterogeneidades do arcabouço litológico e estrutural do SAB e, desse modo, apresentam grandes amplitudes de ocorrência. A condutividade hidráulica do SAB pode variar de 0,002 a $3,660 \mathrm{~m} / \mathrm{d}$, a transmissividade varia de 0,14 a $328 \mathrm{~m}^{2} / \mathrm{d}$, a vazão específica, de 0,022 a 4,9 $\mathrm{m}^{3} / \mathrm{h} / \mathrm{m}$ e as vazões ótimas de explotação variam de inferiores a $10 \mathrm{~m}^{3} / \mathrm{h}$ nos locais de baixa produtividade até $120 \mathrm{~m}^{3} / \mathrm{h}$ nas melhores condições de produtividade (SÃO PAULO, 2005).

$\mathrm{Na}$ área de interesse deste estudo, o Sistema Aquífero Bauru é constituído pelas unidades hidroestratigráficas Adamantina e Santo Anastácio (PAULA E SILVA, 2003), de acordo com a sequência estratigráfica do Grupo Bauru proposta por Soares et al. (1980), com espessura média do pacote sedimentar de $142 \mathrm{~m}$. De acordo com a subdivisão adotada no mapa das águas subterrâneas do Estado de São Paulo (SÃO PAULO, 2005), o SAB na área de estudo corresponde ao domínio "Bauru Médio/Superior", associado às unidades litoestratigráficas do Grupo Bauru proposta por Fernandes (1998).

Os parâmetros hidráulicos de nível estático, espessura saturada, vazão específica ou capacidade específica, vazão de explotação, transmissividade e condutividade hidráulica, relativos ao $\mathrm{SAB}$ na área de interesse deste estudo, foram analisados a partir do banco de dados de poços disponibilizados para esta pesquisa (DAEE, 2008) e apresentados na Tabela 3.1 que traz uma estatística simplificada dos referidos parâmetros.

Tabela 3.1 - Parâmetros hidráulicos do Sistema Aquífero Bauru em São José do Rio Preto*

\begin{tabular}{l|r|r|r|r|r|r}
\hline & $\mathrm{NE}(\mathrm{m})$ & $\mathrm{b}(\mathrm{m})$ & $\mathrm{K}(\mathrm{m} / \mathrm{dia})$ & $\mathrm{T}\left(\mathrm{m}^{2} / \mathrm{dia}\right)$ & $\begin{array}{c}\mathrm{Q} / \mathrm{s} \\
\left(\mathrm{m}^{3} / \mathrm{h} / \mathrm{m}\right)\end{array}$ & $\begin{array}{c}\mathrm{Q}_{\exp } \\
\left(\mathrm{m}^{3} / \mathrm{h}\right)\end{array}$ \\
\hline $\mathrm{n}$ & 629 & 31 & 43 & 81 & 337 & 337 \\
\hline Máximo & 88,00 & 175,50 & 1,070 & 60,0 & 7,58 & 44,0 \\
\hline Mínimo & 1,20 & 77,50 & 0,004 & 0,4 & 0,09 & 1,0 \\
\hline Média & 34,48 & 107,93 & 0,260 & 19,7 & 0,67 & 12,8 \\
\hline Mediana & 32,00 & 102,25 & 0,237 & 15,1 & 0,54 & 10,0 \\
\hline
\end{tabular}

*Dados provenientes do cadastro de poços disponibilizado pelo DAEE (2008).

NE: nível estático; b: espessura saturada do $\mathrm{SAB} ; \mathrm{Q} /$ s: vazão específica; $\mathrm{Q}_{\text {exp }}$ : vazão de explotação determinada por teste de bombeamento, de acordo com as informações do cadastro; T: Transmissividade; K: condutividade hidráulica; n: número de dados disponíveis no cadastro, utilizados na estatística dos parâmetros hidráulicos.

O nível estático (NE), no caso do $\mathrm{SAB}$, tende a representar a potenciometria do nível freático, devido ao caráter predominantemente livre deste sistema aquífero. Ainda que os perfis construtivos dos poços possam refletir condições de pressões hidráulicas de níveis em 
profundidade do aquífero, os níveis estáticos do cadastro demonstram o comportamento de acompanhar a morfologia do relevo, razão pela qual a amplitude de valores é elevada, variando de 1,2 a 88,0 m, em um universo de 629 registros disponíveis no cadastro (Tabela 3.1). Estes dados de nível estático, em geral, foram obtidos dos relatórios de construção dos poços e, desse modo, representam condições do aquífero ao longo das últimas quatro décadas (DAEE, 2008). Adiante, no item relativo ao modelo numérico de fluxo do SAB, será apresentado o mapa potenciométrico da área de estudo e discutido com maior detalhe o comportamento dos níveis estáticos, assim como dos níveis dinâmicos.

Lima (2004) também realizou uma análise estatística com dados de 122 poços instalados em SJRP, identificando um cenário similar, com variação da profundidade dos níveis estáticos de 1,2 a 80,0 m e valor médio de 31,5 m.

A espessura saturada (b) do SAB em SJRP, varia de 77 a 177 m, com valor médio de $108 \mathrm{~m}$ e mediana de $102 \mathrm{~m}$ (Tabela 3.1), avaliado a partir de dados de 31 poços totalmente penetrantes na sequência sedimentar suprabasáltica e que possuem informações de nível estático. Estes valores são compatíveis com o mapa de espessura saturada do SAB, de escala regional, apresentado no texto explicativo do mapa de águas subterrâneas do Estado de São Paulo (SÃO PAULO, 2005).

A condutividade hidráulica (K) foi avaliada a partir de 43 poços que dispunham desta informação, apresentando variação de 0,004 a $1,070 \mathrm{~m} /$ dia (Tabela 3.1), com aproximadamente $60 \%$ dos poços apresentando valores entre 0,1 e $0,5 \mathrm{~m} /$ dia (Figura 3.9) e condutividade hidráulica média para a área de 0,260 m/dia. Os dados analisados concordam com estudo regional que aponta condutividades hidráulicas do SAB variando de 0,002 a 3,66 $\mathrm{m} / \mathrm{dia}$, sendo que, para a região do sistema aquífero que abrange a área de estudo, os valores comuns de condutividade hidráulica variam de 0,1 a 0,4 m/dia (SÃO PAULO, 2005).

As transmissividades $(\mathrm{T})$ do SAB na área de estudo foram analisadas a partir de 81 poços que apresentaram informações consistentes deste parâmetro hidráulico, sendo verificada variação de 0,4 a $60,0 \mathrm{~m}^{2} /$ dia (Tabela 3.1). Apesar da elevada amplitude dos valores de transmissividade da área, mais de $90 \%$ são inferiores a $50 \mathrm{~m}^{2} /$ dia, sendo que $35 \%$ do total são inferiores a $10 \mathrm{~m}^{2} /$ dia (Figura 3.9), justificando uma transmissividade média de $19,7 \mathrm{~m}^{2} /$ dia e mediana de $15,1 \mathrm{~m}^{2} /$ dia, concordando com os resultados descritos por Iritani et al. (2000) relacionados ao setor do SAB que abrange a área do presente estudo. 


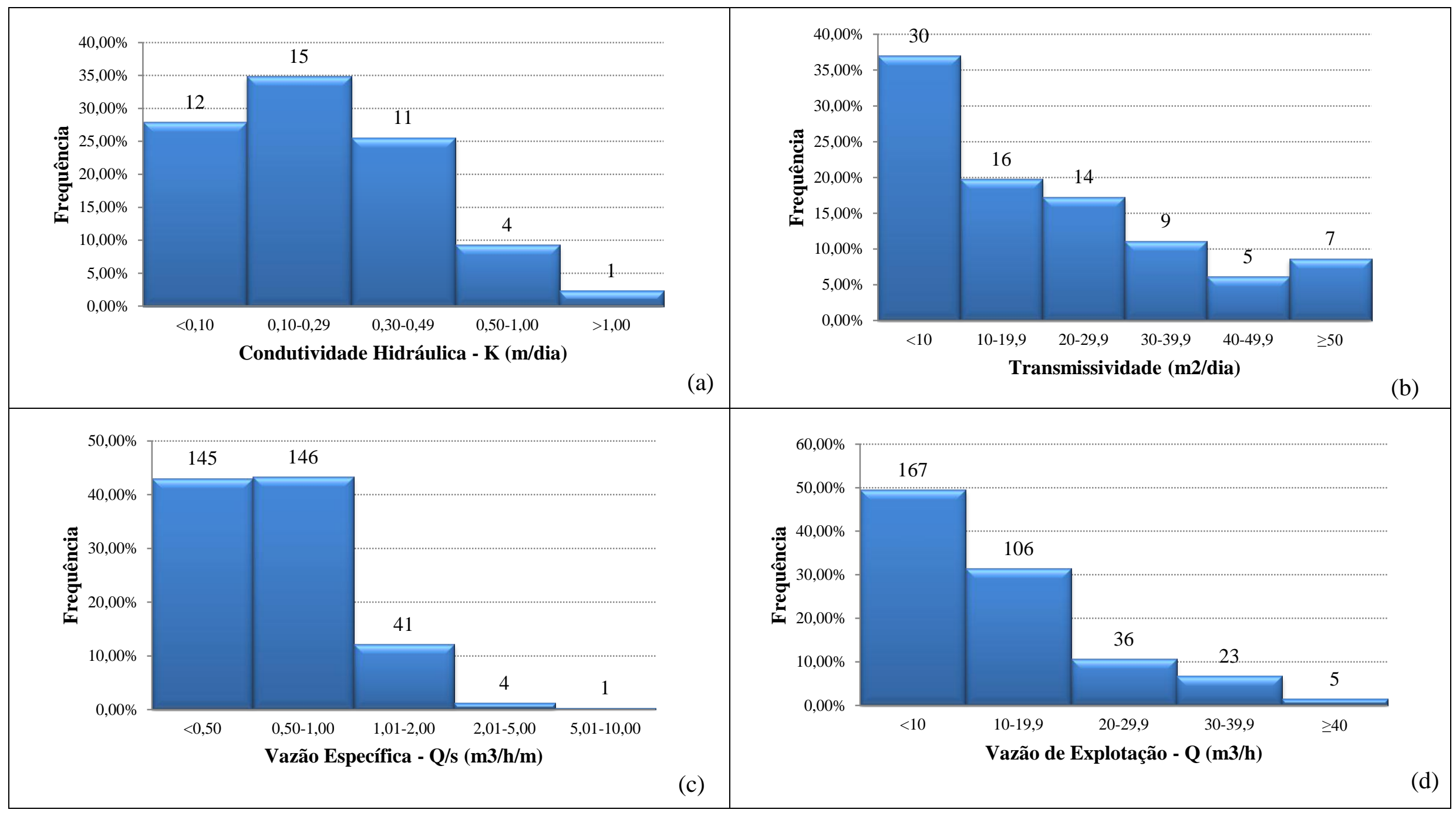

Figura 3.9 - Gráficos de frequência dos parâmetros hidráulicos de condutividade hidráulica (a), transmissividade (b), vazão específica (c) e vazão de explotação (d) do Sistema Aquífero Bauru em São José do Rio Preto 
Os dados de vazão específica $(\mathrm{Q} / \mathrm{s})$ foram avaliados em 337 poços que apresentavam resultados detalhados de ensaios de bombeamento, a partir dos quais foram calculadas as vazões específicas no estudo realizado pelo DAEE (2008). As vazões específicas em SJRP variam de 0,09 a $7,58 \mathrm{~m}^{3} / \mathrm{h} / \mathrm{m}$ (Tabela 3.1), confirmando a heterogeneidade do SAB no local. Entretanto, 98,5\% dos poços avaliados apresentam vazões específicas inferiores a 2,00 $\mathrm{m}^{3} / \mathrm{h} / \mathrm{m}$, sendo que $86 \%$ do total de poços são inferiores a $1,00 \mathrm{~m}^{3} / \mathrm{h} / \mathrm{m}$ (Figura 3.9). Estes resultados são compatíveis com os demonstrados em estudos anteriores (ROCHA et al., 1981; IRITANI et al., 2000; SÃO PAULO, 2005).

As vazões específicas superiores a $2,00 \mathrm{~m}^{3} / \mathrm{h} / \mathrm{m}$ foram encontradas em 5 poços do cadastro, podendo ser consideradas como valores anômalos para este parâmetro hidráulico na área de estudo, de acordo com as avaliações regionais do SAB realizadas pelos autores citados anteriormente, que indicam valores dessa ordem para setores do SAB na região sudoeste do Estado. Embora, assim como neste estudo, o trabalho de Iritani et al. (2000) demonstre alguns resultados dessa magnitude na região de SJRP.

As vazões de explotação (Q) analisadas neste estudo são provenientes de 337 registros existentes no cadastro de poços (DAEE, 2008), representando os valores calculados por meio de ensaios de bombeamento realizados pelos proprietários dos poços para obter o parâmetro de produtividade do poço. Os dados disponíveis mostram que as vazões de explotação variam de 1 a $44 \mathrm{~m}^{3} / \mathrm{h}$ (Tabela 3.1), sendo que, em $50 \%$ dos casos, as vazões são de até $10 \mathrm{~m}^{3} / \mathrm{h}$ e, em cerca de $30 \%$, as vazões estão entre 10 e $20 \mathrm{~m}^{3} / \mathrm{h}$ (Figura 3.9). Esta distribuição propicia um valor médio de vazão de explotação de $12 \mathrm{~m}^{3} / \mathrm{h}$ e mediana de $10 \mathrm{~m}^{3} / \mathrm{h}$. Os dados analisados, considerando tanto a amplitude de variação das vazões quanto os valores médios estão compatíveis com as avaliações realizadas em estudos anteriores (BARCHA, 1980; ROCHA et al., 1981; IRITANI et al., 2000; SÃO PAULO, 2005).

Em diversos casos, os ensaios de bombeamento foram realizados para comporem os processos de solicitação de outorga de uso das águas subterrâneas, no qual o volume outorgado é obtido pela vazão de explotação por um regime diário de bombeamento que varia em função das necessidades do usuário e da avaliação técnica proveniente do ensaio de bombeamento executado. É possível que as reais vazões de explotação possam variar das calculadas, devido ao regime de bombeamento imposto pelo usuário. Neste tópico, focou-se a discussão apenas acerca das vazões de explotação calculadas, adiante, serão discutidos os dados e cálculos sobre os volumes explotados do SAB na área de estudo. 
A aplicação dos parâmetros hidráulicos locais do SAB, a discussão sobre o comportamento do fluxo subterrâneo e a caracterização do modelo hidrogeológico conceitual da área de estudo são temas que serão discutidos adiante, em capítulos específicos relacionados ao cálculo do volume explotado do $\mathrm{SAB}$, modelo numérico do fluxo subterrâneo e ao cálculo do custo de energia na explotação das águas subterrâneas em SJRP.

\subsection{INFRAESTRUTURA HÍDRICA DE ABASTECIMENTO DE ÁGUA}

Neste tópico são apresentados dados do abastecimento de água de SJRP, visando caracterizar a infraestrutura hídrica tanto do sistema de abastecimento público quanto das iniciativas individuais de suprimento de água identificadas pelo cadastro de poços produtores do DAEE (2008).

A infraestrutura hídrica de uma cidade está diretamente ligada à sua história, modelo de ocupação e decisões políticas que possibilitam obter melhores ou piores indicadores do atendimento de abastecimento de água.

No intuito de criar uma relação com o panorama nacional, segundo o Instituto Brasileiro de Geografia e Estatística (IBGE), em 2008, o serviço de abastecimento de água no País alcançou 99,4\% dos municípios, com atendimento total ou parcial deste serviço, sendo que no Sudeste, $100 \%$ dos municípios são atendidos. A taxa de cobertura do abastecimento em cada município tem valor médio nacional de 78,6\% e, na região Sudeste, a média é de $87,5 \%$ dos domicílios atendidos (IBGE, 2010). Vale ressaltar que a universalização do atendimento de abastecimento de água é um direito de todos e dever do Estado, no caso, de competência dos Governos Municipais, conforme estabelecido pela Lei $\mathrm{N}^{\mathrm{O}} 11.445$, de 05 de janeiro de 2007, conhecida como a Lei do Saneamento.

A taxa de consumo médio de água per capta no Brasil, segundo dados de 2008 do Sistema Nacional de Informações sobre Saneamento (SNIS), foi calculada em 151 1/hab.dia (litros diários por habitante). Na região Sudeste, o consumo médio calculado foi de 178 1/hab.dia e, no Estado de São Paulo, 176 1/hab.dia (SNIS, 2011). 


\subsubsection{Abastecimento público de água}

A cobertura do serviço de abastecimento público de água em São José do Rio Preto possui indicador acima das médias nacional e regional, contando com $99 \%$ da população atendida pelo referido serviço de saneamento (PMSJRP, 2011). Os serviços de abastecimento de água, bem como os de coleta e tratamento de esgoto são prestados e gerenciados pela autarquia municipal, Serviço Municipal Autônomo de Água e Esgoto (Semae).

O sistema de abastecimento de água de São José do Rio Preto realizado pelo Semae conta com a captação de três fontes hídricas distintas, sendo águas subterrâneas do Sistema Aquífero Bauru (SAB) e do Sistema Aquífero Guarani (SAG) e águas superficiais do rio Preto, distribuídas por uma rede de $1.433 \mathrm{~km}$ de extensão, atendendo quase 120 mil ligações (PMSJRP, 2011). As águas subterrâneas são responsáveis por $73 \%$ do abastecimento público de SJRP, conforme ilustra a Figura 3.10.

\section{Fontes hídricas do abastecimento público}

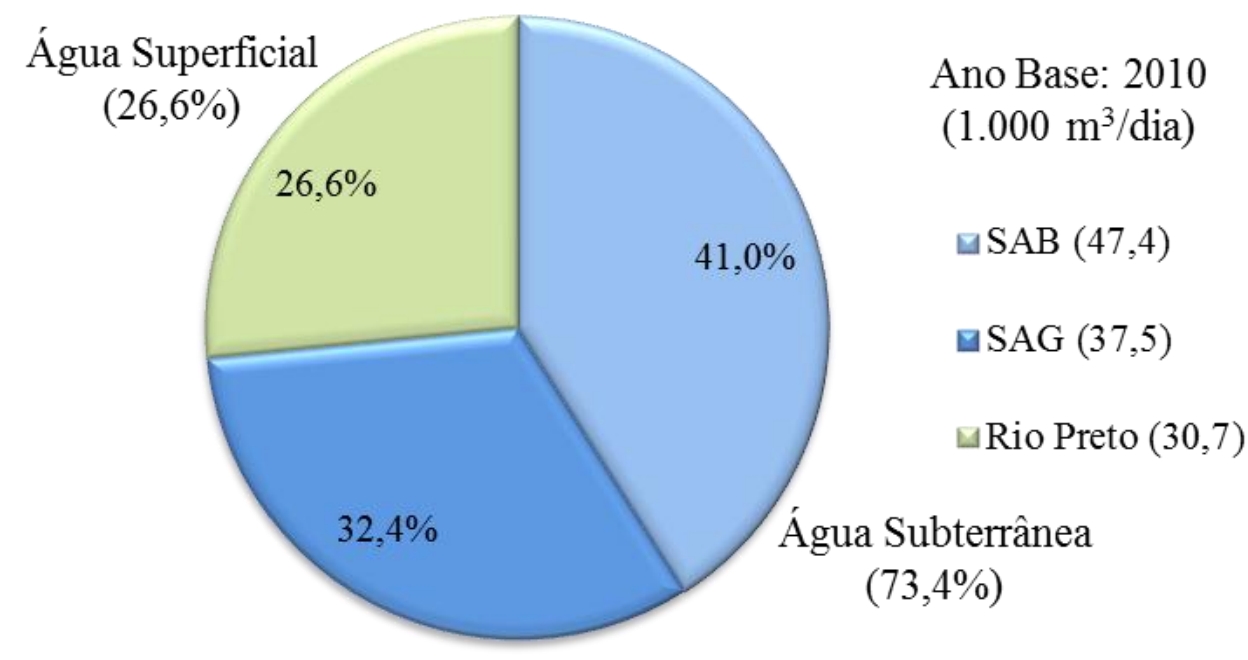

Fonte: PMSJRP, 2011

Figura 3.10 - Gráfico da distribuição das fontes hídricas do abastecimento público de SJRP no ano de 2010 com informação sobre aos percentuais de água subterrânea e superficial 
A Tabela 3.2 mostra a evolução do volume produzido pelo Semae, no período de 2007 a 2010, apresentando o percentual de água extraído das diferentes fontes que abastecem o sistema de distribuição pública de água.

Tabela 3.2 - Fontes e volumes do abastecimento público de água de SJRP

\begin{tabular}{l|c|c|c|c|c|c|c|c}
\hline \multirow{2}{*}{ Fonte } & \multicolumn{2}{|c|}{2007} & \multicolumn{2}{c|}{2008} & \multicolumn{2}{c|}{2009} & \multicolumn{2}{c}{2010} \\
\cline { 2 - 9 } & $\%$ & $\mathrm{~m}^{3} / \mathrm{dia}$ & $\%$ & $\mathrm{~m}^{3} / \mathrm{dia}$ & $\%$ & $\mathrm{~m}^{3} / \mathrm{dia}$ & $\%$ & $\mathrm{~m}^{3} / \mathrm{dia}$ \\
\hline Rio Preto & $27,62 \%$ & 31.190 & $26,32 \%$ & 30.156 & $26,54 \%$ & 29.725 & $26,54 \%$ & 30.681 \\
\hline SAB & $41,41 \%$ & 46.762 & $40,82 \%$ & 46.769 & $40,98 \%$ & 45.898 & $40,98 \%$ & 47.374 \\
\hline SAG & $30,97 \%$ & 34.973 & $32,86 \%$ & 37.649 & $32,48 \%$ & 36.378 & $32,48 \%$ & 37.548 \\
\hline Vol. Produzido & & 112.925 & & 114.574 & & 112.002 & & 115.602 \\
\hline
\end{tabular}

Fonte: PMSJRP, 2008, 2009, 2010, 2011

Os relatórios de Conjuntura Econômica da PMSJRP (2008, 2009, 2010, 2011) apontam também o volume de água faturado pelo Semae. A diferença entre o volume produzido e o faturado foi considerada como equivalente às perdas de água sofridas pela rede de distribuição, conforme demonstrado na Tabela 3.3.

Tabela 3.3 - Estimativas das perdas da rede de distribuição de água

\begin{tabular}{l|r|r|r|r}
\hline \multicolumn{1}{c|}{ Fonte } & \multicolumn{1}{c|}{2007} & \multicolumn{1}{c|}{2008} & \multicolumn{1}{c|}{2009} & \multicolumn{1}{c}{2010} \\
\hline Volume Produzido $\left(\mathrm{m}^{3} / \mathrm{dia}\right)$ & 112.925 & 114.574 & 112.002 & 115.602 \\
\hline Volume Faturado $\left(\mathrm{m}^{3} / \mathrm{dia}\right)$ & 74.830 & 76.778 & 79.392 & 83.361 \\
\hline Perdas $\left(\mathrm{m}^{3} / \mathrm{dia}\right)$ & 38.095 & 37.796 & 32.610 & 32.241 \\
\hline Perdas $(\%)$ & $33,7 \%$ & $33,0 \%$ & $29,1 \%$ & $27,9 \%$ \\
\hline
\end{tabular}

Fonte: PMSJRP, 2008, 2009, 2010, 2011

A diferença entre os indicadores do Semae adotados na Tabela 3.3 é provável conter perdas administrativas e/ou financeiras, uma vez que o indicador "volume faturado" representa uma receita financeira convertida no produto de venda da empresa, a água. De qualquer maneira, não é possível obter um indicador preciso da perda física da rede de distribuição, visto que este incidente ocorre imprevisivelmente e, na maioria dos casos, de modo imperceptível. 
Pelos motivos acima tratados, a diferença entre os volumes produzido e faturado foi atribuída como a estimativa das perdas físicas da rede de distribuição. As perdas das redes representam desperdícios do recurso água e de energia elétrica, elevando os custos de produção da água consumida e, consequentemente, o valor pago pelos usuários do sistema público de abastecimento que pagam pela água produzida, porém perdida no processo.

A Figura 3.11 ilustra a proporção de perdas do sistema de captação e distribuição de água, estimadas pela diferença entre os volumes produzido e faturado relativos ao ano de 2010, de acordo com dados disponibilizados pela PMSJRP (2011).

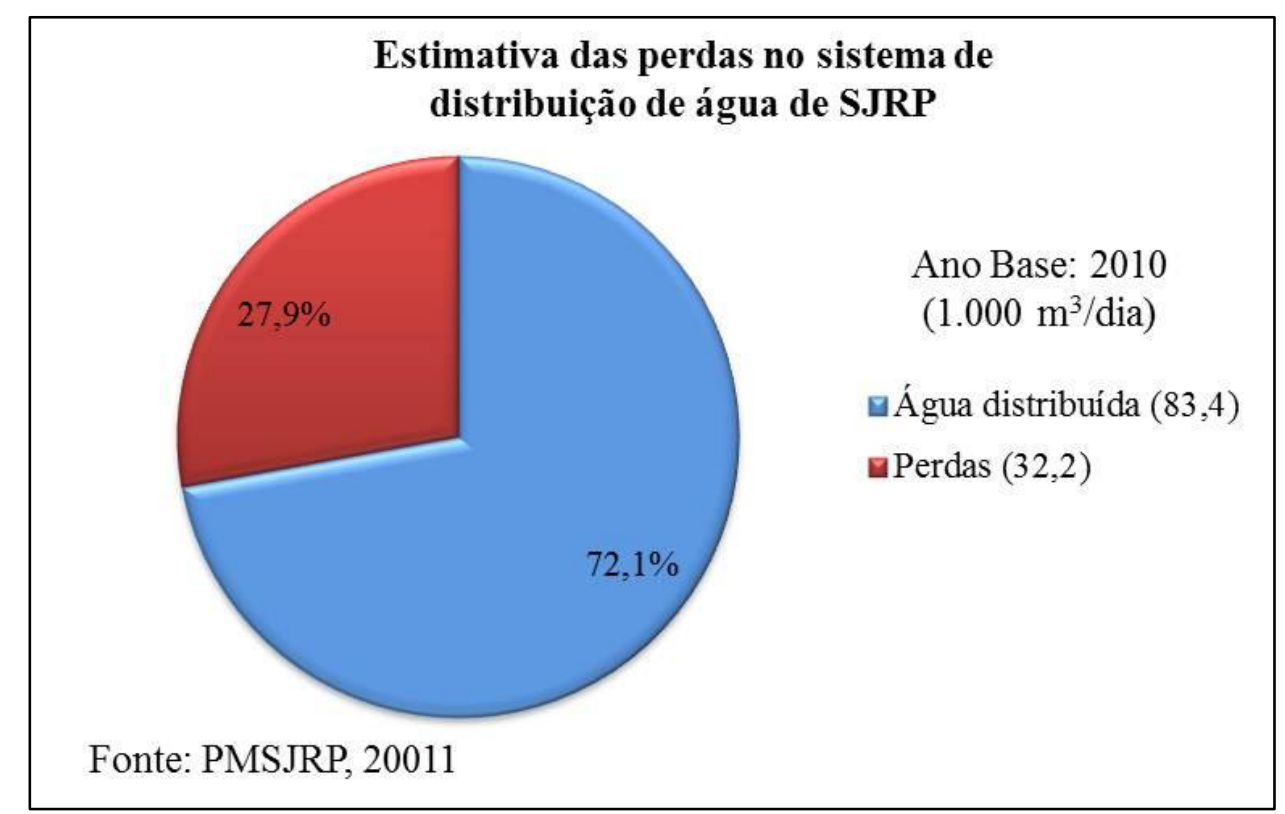

Figura 3.11 - Estimativa das perdas do sistema de distribuição de água de SJRP no ano de 2010 com base na diferença dos volumes produzido e faturado

Os volumes captados dos mananciais subterrâneos são, atualmente, explotados a partir de 213 poços instalados no SAB e 8 poços captando o SAG (PMSJRP, 2011). A base de dados utilizadas nesta pesquisa possui 195 poços de abastecimento público, dos quais, 180 estavam em operação explotando o $\mathrm{SAB}$, de acordo com os dados do cadastro de poços do DAEE (2008). A Figura 3.12 mostra a distribuição de todos os poços de abastecimento público existentes no cadastro do DAEE (2008), instalados para a explotação do SAB, identificando a condição operacional dos mesmos.

A água distribuída pelo Semae representa uma taxa de consumo diário por habitante de 184 litros, de acordo com o método de cálculo e os dados do SNIS (2008). Este valor é cerca de 5\% superior à média calculada para o Estado de São Paulo (SNIS, 2011) e corresponde aproximadamente às taxas normais de consumo. 
No entanto, o consumo de água no município conta com uma significativa contribuição de poços particulares, conforme será tratado adiante, a partir da apresentação do cadastro de poços e do cálculo das estimativas de explotação do SAB. Desse modo, os dados oficiais de consumo de água do município não são condizentes com a realidade existente.

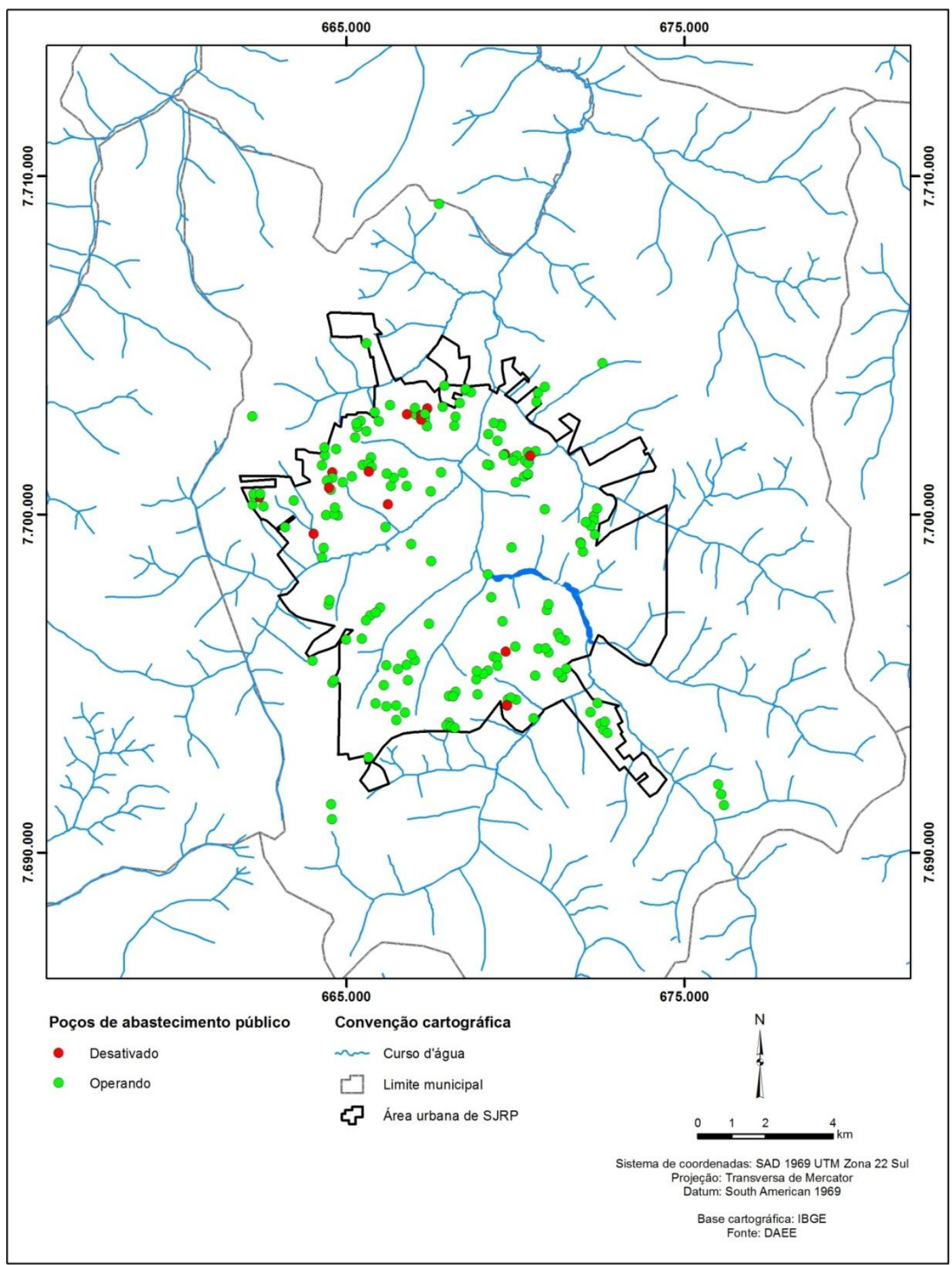

Figura 3.12 - Localização dos poços de abastecimento público de São José do Rio Preto 


\subsubsection{Caracterização da rede de poços de captação do $S A B$}

Este projeto de pesquisa foi desenvolvido, em grande parte, embasado nas informações sobre poços organizadas em um banco de dados, denominado de cadastro de poços, disponibilizado pelo Departamento de Águas e Energia Elétrica (DAEE), órgão gestor dos recursos hídricos no Estado de São Paulo.

O banco de dados foi consistido pela empresa Servmar Ambiental, como parte do escopo de estudos hidrogeológicos executados em SJRP (DAEE, 2008), que compilou, sistematizou e georreferenciou as informações provenientes de bases de dados fornecidas pelo DAEE, pelo Serviço Geológico do Brasil (Companhia de Pesquisa dos Recursos Minerais CPRM), pelo Instituto de Pesquisas Tecnológicas (IPT) e pelo Semae.

Os poços podem ser considerados como elementos da infraestrutura hídrica de abastecimento de água, pois são os responsáveis pela produção, neste caso, das águas subterrâneas do SAB.

O cadastro possui dados relativos a 2.003 poços produtores, dos quais, mais de $99 \%$ são tubulares, com profundidades variando de 18 a 248 m, com profundidade média de $112 \mathrm{~m}$ e mediana de $100 \mathrm{~m}$, avaliadas em 763 poços que registram essa informação. A Figura 3.13 apresenta a frequência dos dados de profundidade e a Figura 3.14 apresenta a localização dos poços na área de estudo, segundo as profundidades definidas no gráfico de frequência.

No gráfico de frequência da Figura 3.13, pode-se observar que quase a metade dos poços analisados possuem entre 71 e $100 \mathrm{~m}$ e que cerca de $80 \%$ dos poços apresentam profundidades entre 71 e $160 \mathrm{~m}$.

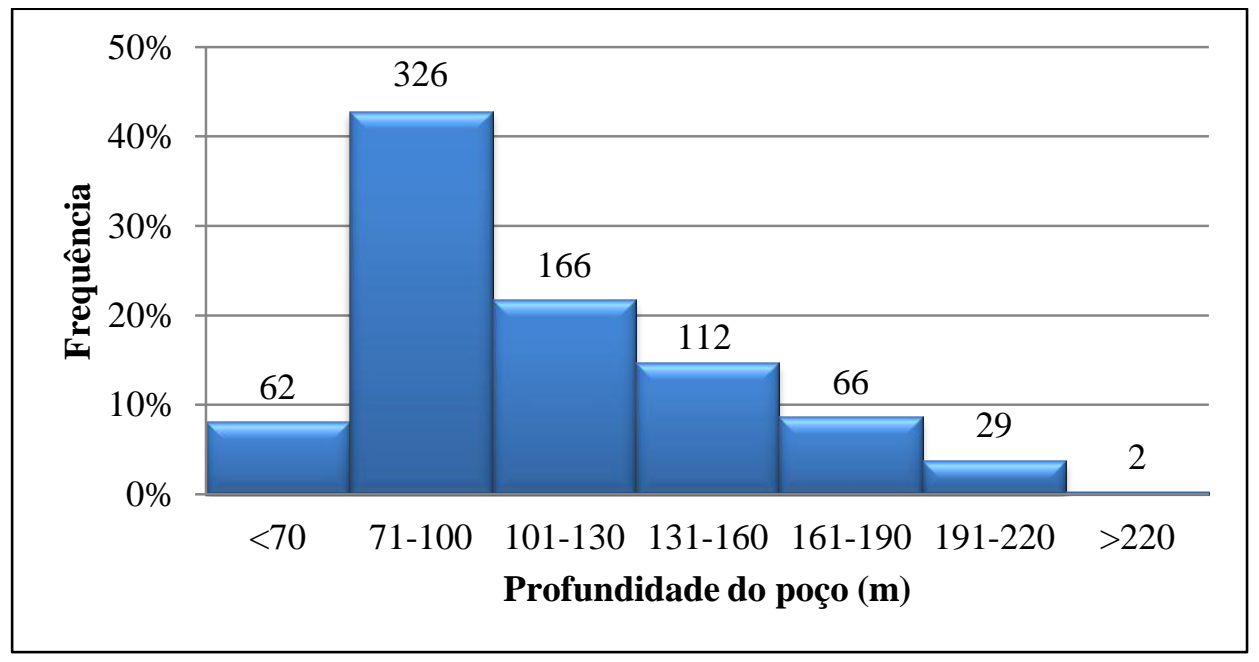

Figura 3.13 - Gráfico de frequência dos dados de profundidade dos poços 


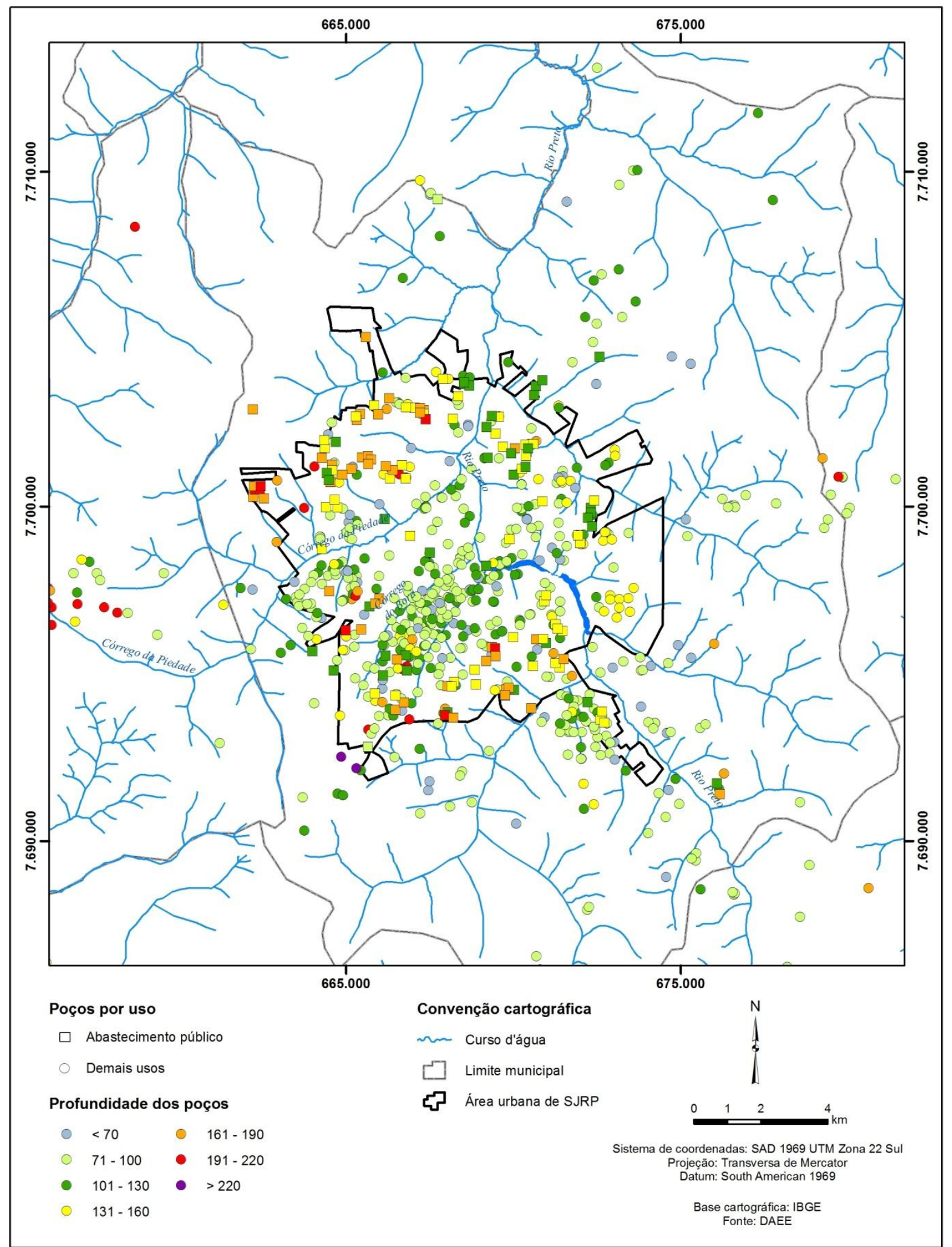

Figura 3.14 - Distribuição dos poços na área de estudo classificados em faixas de profundidade construtiva 
O poço tubular é uma obra de hidrogeologia para acessar um ou mais aquíferos para captação de água subterrânea, cuja construção é realizada por sonda perfuratriz, mediante perfuração com diâmetro nominal de revestimento mínimo de 101,6 mm (4”), podendo ser parcial ou totalmente revestido em função da geologia local (ABNT, 2006). Os poços tubulares também podem ser popularmente chamados de poços profundos, independentemente de sua profundidade, e comercialmente denominados, de maneira inadequada, de poços artesianos ou semi-artesianos.

A extração das águas subterrâneas pode ocorrer também por meio de poço escavado, também denominado de cacimba e popularmente chamado de poço caipira ou poço amazonas em algumas localidades. Este tipo de poço corresponde a uma obra de captação de água subterrânea construída manualmente através da escavação, em geral, de grande diâmetro (entre 1 e 1,5 m), utilizado para extrair água de aquíferos livres e rasos, com profundidades normalmente inferiores a 30 m (IRITANI; EZAKI, 2009). Estima-se que a ocorrência desse tipo de poço seja pontual, presentes em propriedades na zona rural do município e, possivelmente, em poucas residências em bairros de baixa renda. No cadastro de poços existem 2 registros deste tipo de poço, porém não possuem quaisquer dados técnicos de interesse ao presente estudo.

Os poços do cadastro possuem os dados das coordenadas de suas posições geográficas, ou seja, estão georreferenciados, permitindo regionalizar as informações destes elementos de infraestrutura hídrica, facilitando o tratamento dos dados de interesse e a gestão do uso das águas subterrâneas. Todos os poços do cadastro estão inseridos na área de interesse deste estudo, sendo que mais de 95\% dos poços estão situados na zona urbana de SJRP, representando um elevado adensamento nessa região, conforme pode ser observado na Figura 3.15 que ilustra a distribuição dos poços tubulares cadastrados na zona urbana. Devese salientar o cenário de elevada concentração de poços na parte central da cidade, onde o adensamento pode atingir algumas centenas de poços em $1 \mathrm{~km}^{2}$.

Nos registros existentes no cadastro de poços, apenas 367 constavam na relação de poços outorgados do DAEE, ou seja, apenas 18,4\% dos poços compilados no estudo do DAEE (2008) estavam de acordo com a Lei $\mathrm{N}^{0}$ 6.134, de 02 de junho de 1988, e seu Decreto $\mathrm{N}^{\mathrm{o}}$ 32.955, de 07 de fevereiro de 1991, vigentes no Estado de São Paulo e que regulamentam as autorizações para a construção de poços e uso das águas subterrâneas. 


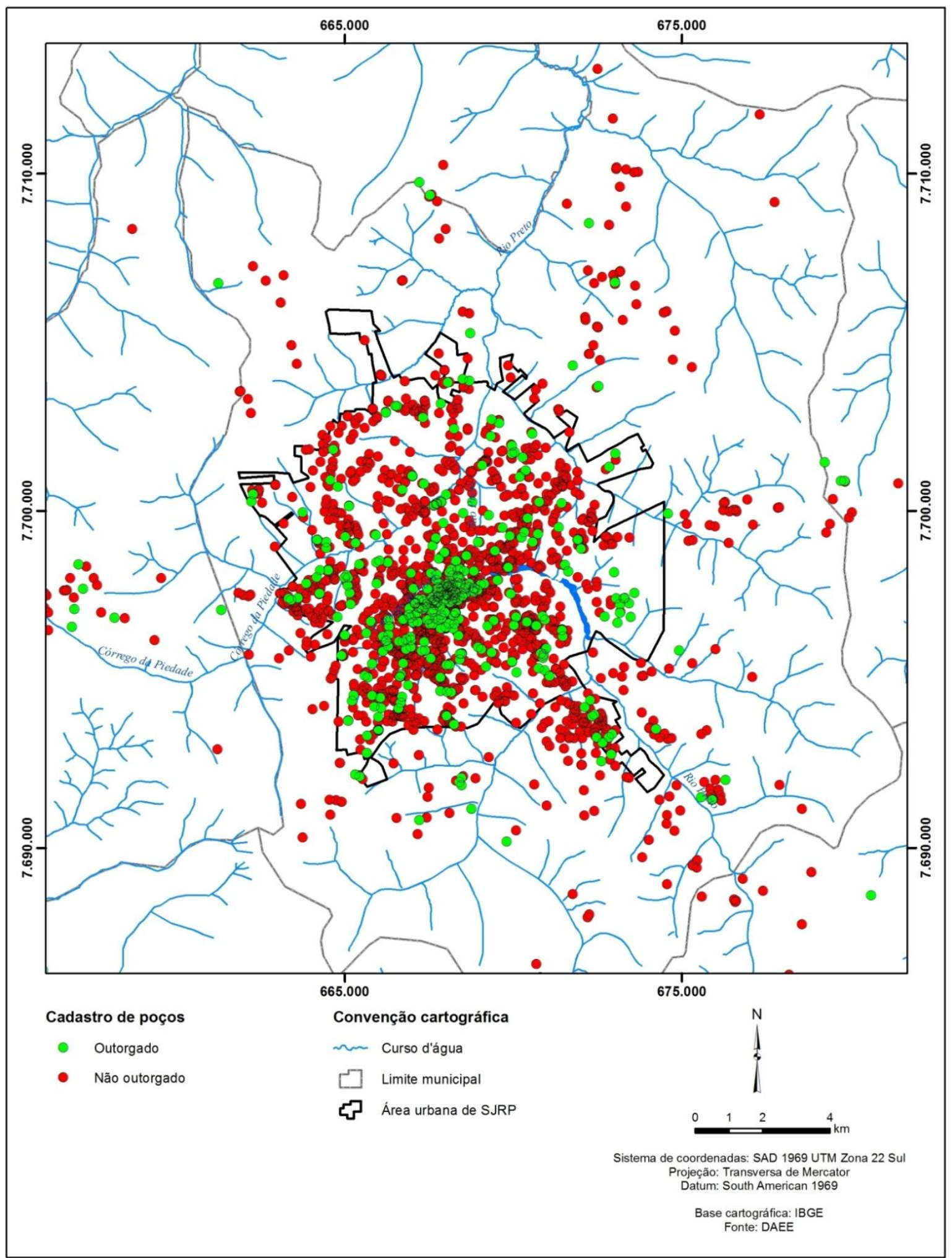

Figura 3.15 - Localização dos poços na área de estudo com a distinção entre poços outorgados e sem outorga de uso das águas 
O cenário de elevada desobediência à legislação dificulta a adequada gestão dos recursos hídricos subterrâneos, pois não há controle e, tão pouco, conhecimento sobre as reais condições de uso da água subterrânea sob os aspectos quantitativo e qualitativo. Deve-se ressaltar que a elaboração do cadastro foi um avanço, porém, foi apenas o primeiro passo.

Certamente, o cadastro não inclui a totalidade de poços existentes na zona urbana de SJRP, entretanto, estima-se que seu conteúdo represente percentual acima de $80 \%$ dos poços existentes. Conforme relatado no estudo do DAEE (2008), uma grande contribuição ao cadastro foi dada pelo Semae que identificou poços que eram desconhecidos pelo órgão gestor dos recursos hídricos.

O Semae realizou um trabalho de reconhecimento de cerca de 900 poços com o intuito principal de dimensionar a geração de esgotos, razão pela qual, acredita-se que a grande maioria dos poços no perímetro urbano tenha sido identificada. No entanto, este levantamento não teve o objetivo de cadastrar informações técnicas e operacionais sobre os poços, possuindo lacunas de informações sobre a grande maioria dos atributos elencados no cadastro. As informações disponíveis dos poços identificados pelo Semae são, em geral, os dados de localização, identificação do usuário e volume consumido de água.

A Figura 3.16 apresenta o gráfico da distribuição dos usos dos poços cadastrados, de acordo com o setor econômico da atividade. Os poços sem informação deste atributo, em geral, são provenientes do levantamento realizado pelo Semae.

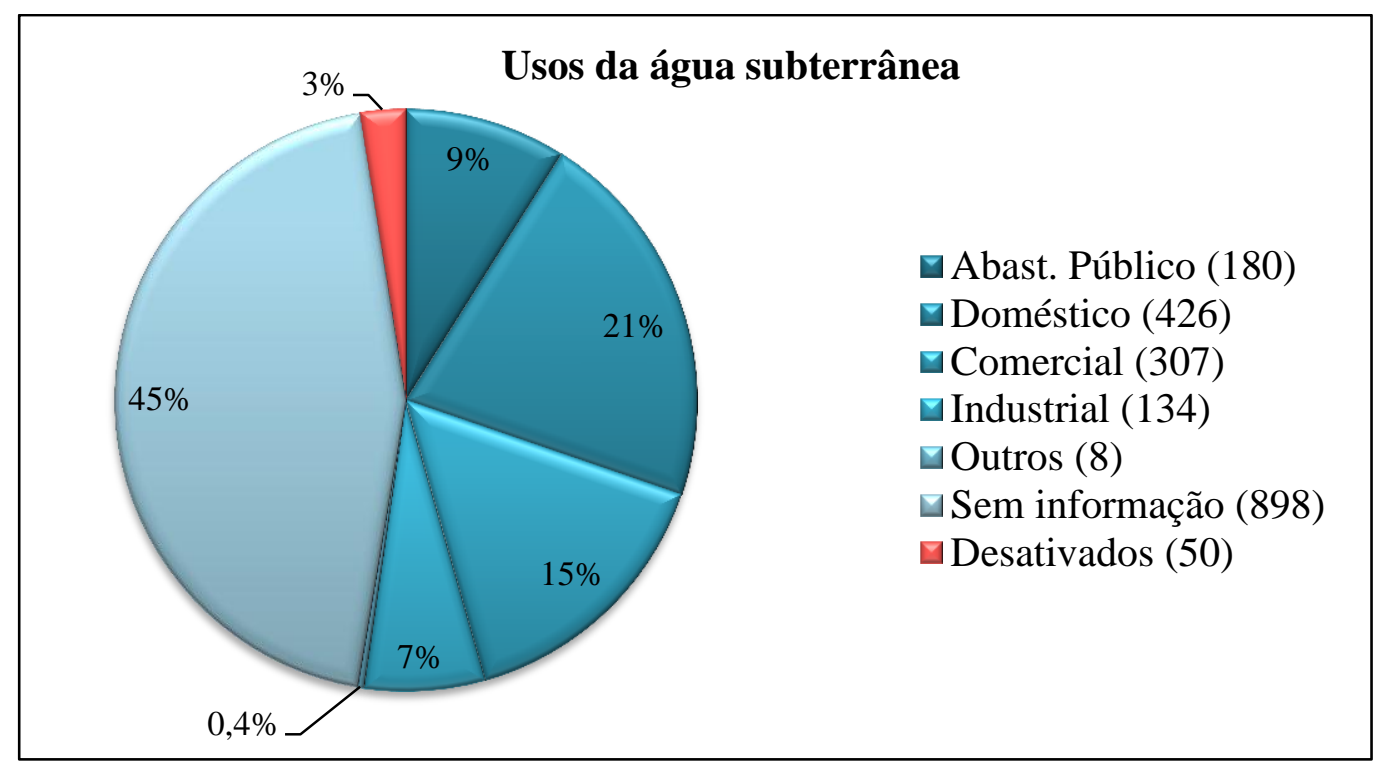

Fonte: DAEE, 2008

Figura 3.16 - Distribuição dos usos das águas subterrâneas nos setores econômicos 
Os poços de abastecimento público são de propriedade do Semae, sendo que, à época da elaboração do cadastro, totalizavam 195 poços, sendo 180 em operação. A localização dos poços de abastecimento público pode ser observada na Figura 3.12. Atualmente o Semae conta com 226 poços, dos quais, 213 estão em operação (PMSJRP, 2011). Entretanto, os dados posteriores ao cadastro do DAEE (2008) não foram disponibilizados pelo Semae para este estudo.

A Figura 3.17 apresenta a localização dos poços na área de estudo classificados de acordo com a finalidade de uso, seguindo o mesmo critério adotado no gráfico de distribuição apresentado anteriormente.

O uso denominado doméstico refere-se aos poços privados que são utilizados para o abastecimento residencial, em moradias individuais e condomínios. Este perfil de usuário possui significativo papel no abastecimento das demandas da população, complementarmente ao abastecimento público. Nota-se que os poços domésticos representam $40 \%$ dos que possuem a informação de uso.

Os poços classificados como "comercial", estão distribuídos em uma enorme variedade de estabelecimentos comerciais e de serviços com diversas aplicações do uso da água. Estão incluídos nesta classificação os poços instalados em hotéis, lava-rápidos, postos de combustíveis, restaurantes, instituições públicas, escolas, entre diversos outros empreendimentos.

Os usos comerciais e domésticos abrangem a grande maioria dos usuários privados que possuem a informação de uso. Desse modo, estima-se que estes perfis de usuários representem quase a totalidade dos poços sem informação de uso.

O uso industrial, segundo esta classificação, não faz distinção à aplicação do uso, por exemplo, se utilizado no processo ou nas dependências da empresa para consumo dos funcionários. A classificação foi feita levando-se em conta que os proprietários dos poços são empreendimentos industriais.

Os usos classificados por "outros" correspondem a dois poços com finalidade para recreação, dois para dessedentação de animais e 4 para irrigação.

Na avaliação de todo o elenco de poços, segundo os usos por categoria econômica, pode-se inferir que a finalidade de uso para o consumo humano abrange a grande maioria dos poços. Os dados do cadastro não permite essa análise de maneira detalhada, entretanto, com exceção feita aos classificados como "outros" e usos exclusivos em processos industriais e comerciais menos nobres, todos os demais tem finalidade direta ou indireta no consumo humano. 


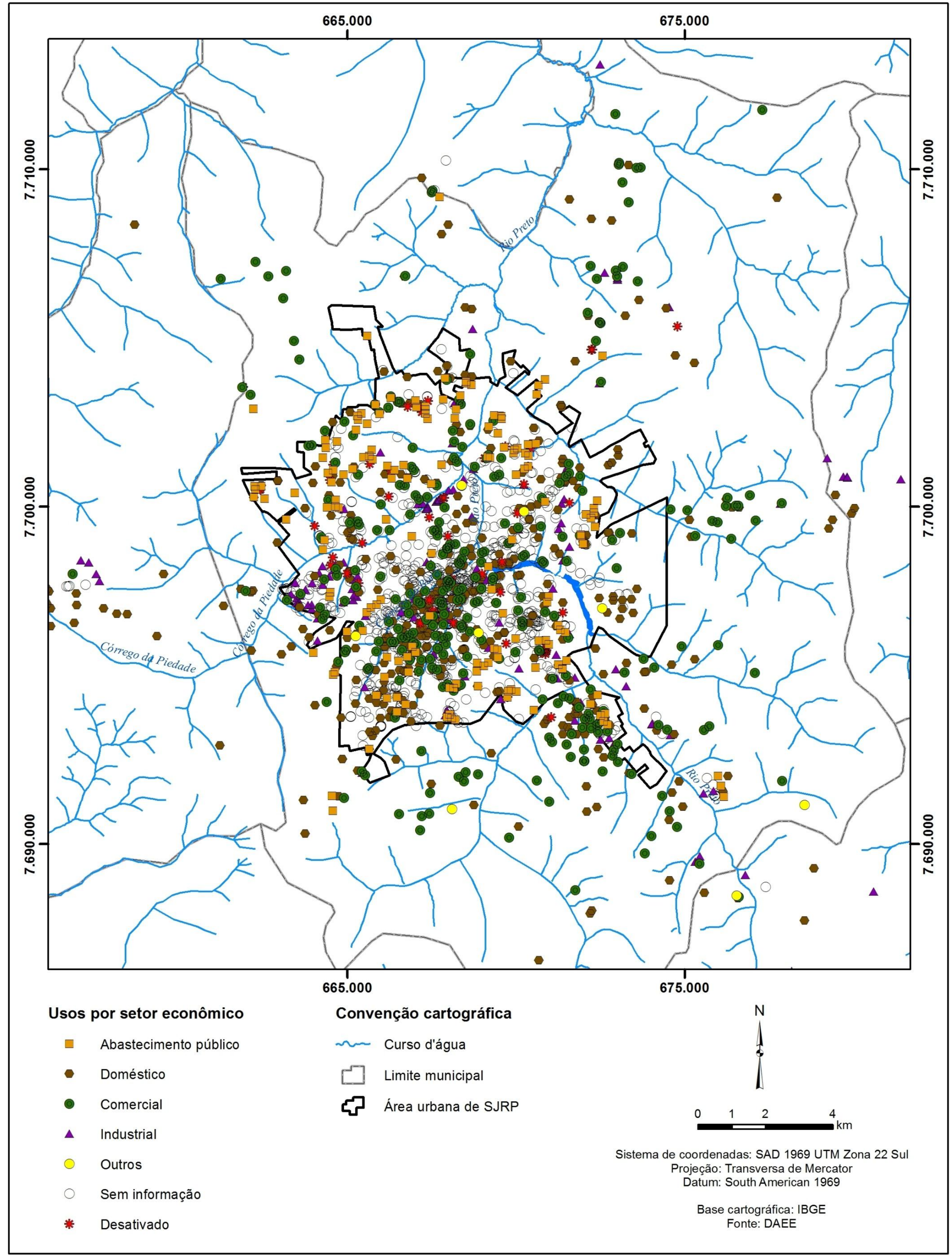

Figura 3.I I - Localizaçäodos poçosnaáreade estudo classiticados pela tinalıdade de uso 


\subsubsection{Explotação das águas subterrâneas do $S A B$}

Este tópico apresenta os dados e a estimativa do volume explotado do Sistema Aquífero Bauru em São José do Rio Preto, desenvolvida com base nas informações disponíveis no cadastro de poços do DAEE (2008).

A explotação de um aquífero é expressa por um dado de vazão, ou seja, um determinado volume por um determinado período de tempo. Os cálculos para a determinação do volume total explotado do aquífero devem considerar a vazão extraída de cada poço.

Os estudos hidrogeológicos comumente são desenvolvidos em condições de poucas informações sobre a grande maioria dos poços existentes na área de interesse, em geral, devido ao contexto de invisibilidade e de elevada clandestinidade do uso das águas subterrâneas. Desse modo, as estimativas de volume explotado são geralmente obtidas estabelecendo-se valores médios de vazão, tempo de bombeamento e quantidade de poços em operação. Como exemplo, Barcha (1998) estimou um volume explotado do SAB em SJRP de $110.000 \mathrm{~m}^{3} /$ dia, considerando a existência de aproximadamente 3.500 poços, com vazão média de produção de $10 \mathrm{~m}^{3} / \mathrm{h}$ por um regime médio de bombeamento entre 2 e $3 \mathrm{~h} /$ dia.

No caso do presente estudo, dispõe-se de um elenco de dados que permite estabelecer com maior segurança as premissas adotadas nas estimativas do volume explotado e, ao mesmo tempo, confirmar ou atualizar, os valores médios dos parâmetros de interesse adotados historicamente pelos estudos hidrogeológicos desenvolvidos nesta região.

A estimativa do volume total explotado do SAB em SJRP foi embasada em diferentes tipos de dados de vazões, de acordo com a disponibilidade da informação no cadastro de poços do DAEE (2008). Desse modo, julgou-se adequado apresentar algumas definições, segundo critérios estabelecidos no presente estudo, para distinguir os diferentes tipos de dados utilizados nas estimativas, conforme a seguir:

Vazão Medida - dado obtido pela medição com hidrômetro. Os dados de vazão desta categoria foram fornecidos ao DAEE pelo Semae e referem-se às leituras dos hidrômetros instalados nos poços. Estes dados correspondem ao volume de água efetivamente retirado do aquífero, no período de medição, que é realizado mensalmente.

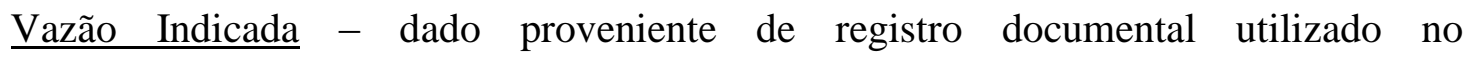
cadastramento. Os dados de vazão desta categoria podem corresponder ao volume máximo de explotação definido na outorga de uso da água concedida pelo poder público; ou a vazão ótima de explotação definida por teste de bombeamento; ou um dado de vazão de produção 
informado pelo proprietário do poço. Estes dados não correspondem necessariamente ao volume real extraído do poço.

Ressalta-se que parte dos poços não possui qualquer tipo de dado de vazão, conforme pode ser observado na Figura 3.18 que apresenta a distribuição dos dados do cadastro, conforme as categorias definidas neste estudo.

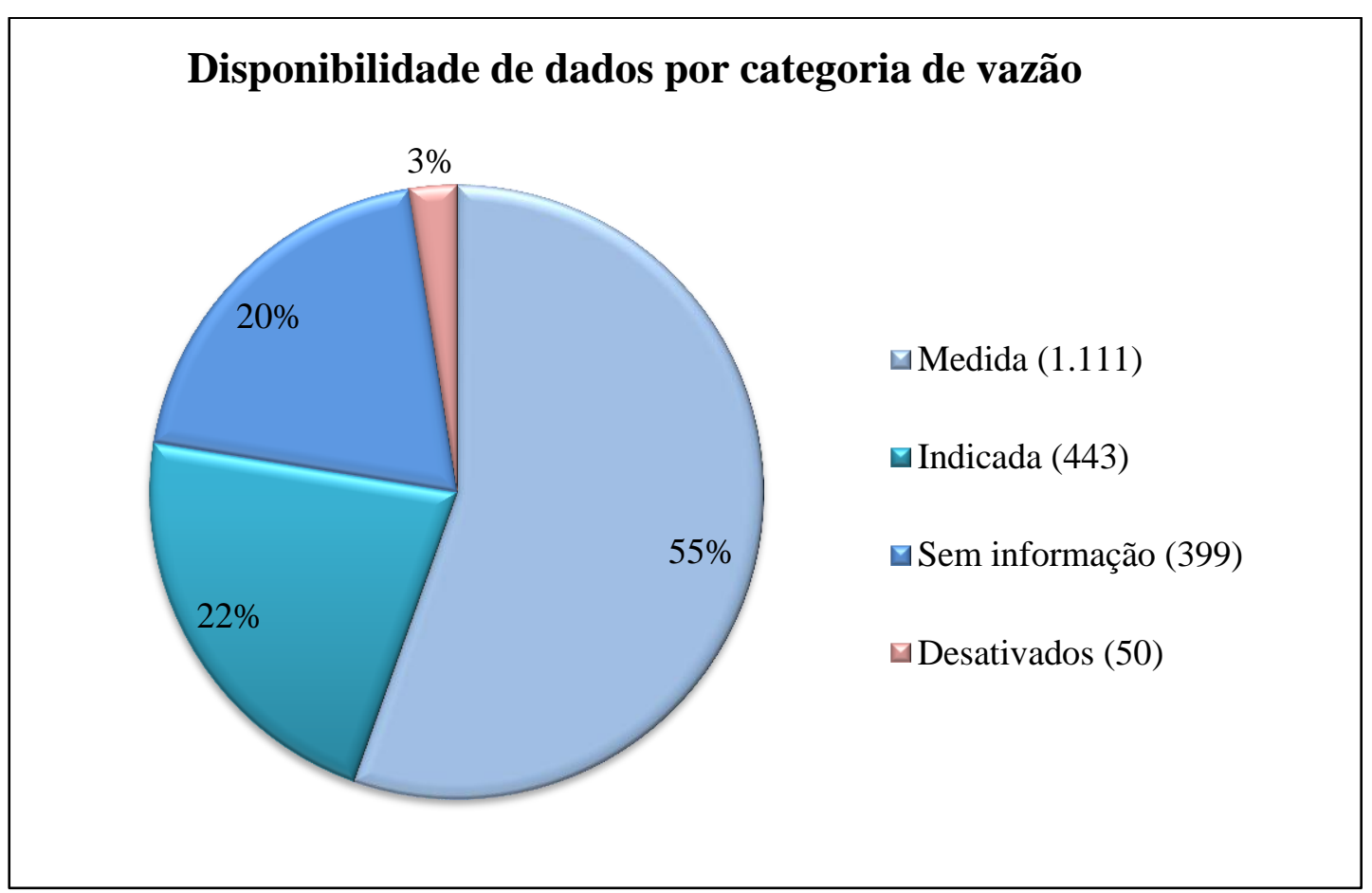

Figura 3.18 - Gráfico da distribuição de dados de vazão por categoria com a indicação da quantidade de registros disponíveis, indisponíveis e poços desativados

A Figura 3.19 mostra a localização em mapa dos poços, classificados de acordo com as categorias de dados de vazão estabelecidas.

Nota-se que os dados de vazão medida estão disponíveis em $55 \%$ dos poços do cadastro, devendo-se destacar o avanço que este cenário representa aos estudos hidrogeológicos do SAB nesta região, por contar com uma expressiva quantidade de dados confiáveis sobre o volume de água retirado desse manancial subterrâneo. Os dados deste elenco de poços, pela elevada qualidade da informação, permitiram balizar as estimativas de explotação dos poços sem informação e refinar os dados de vazão estimada, conforme será demonstrado adiante. 


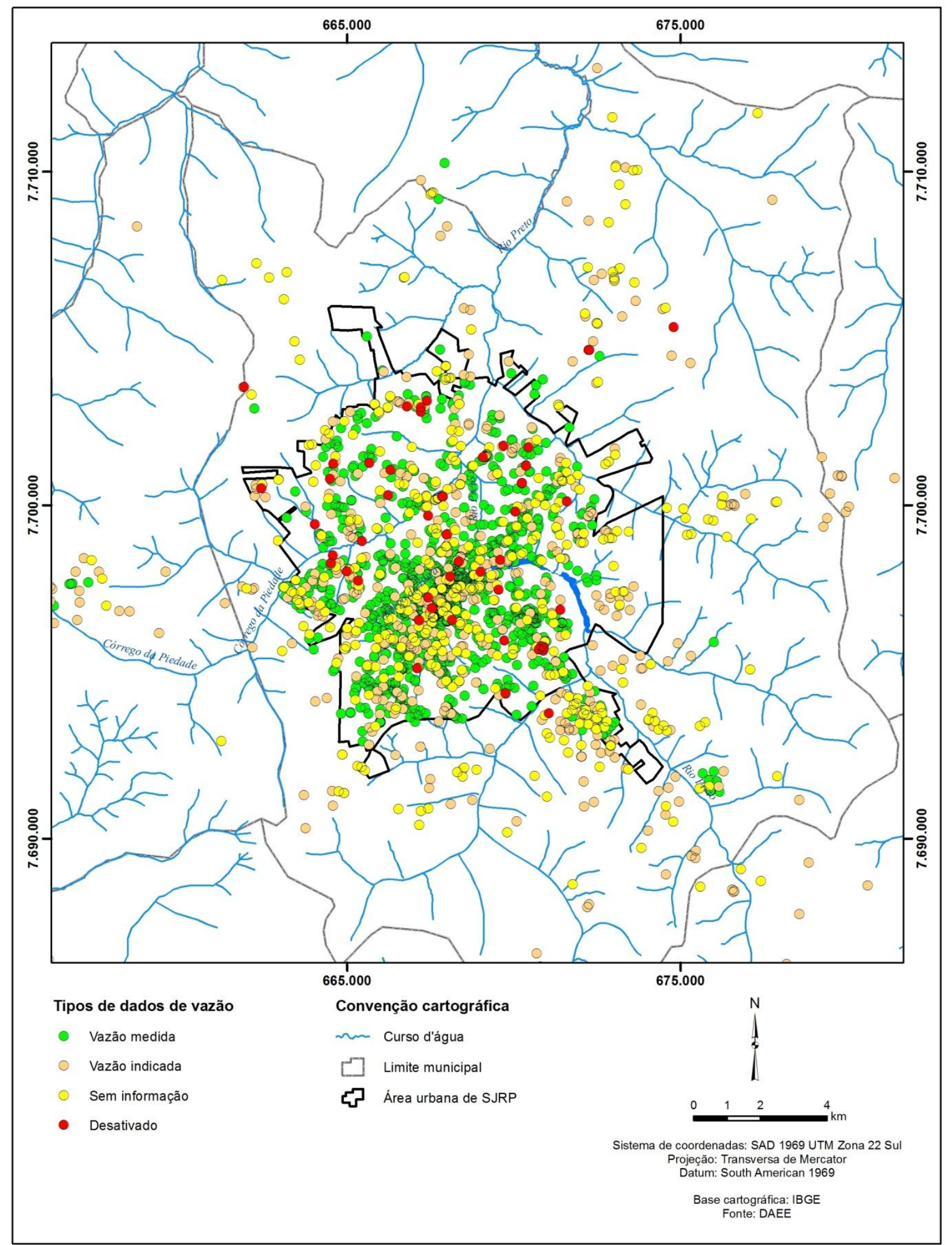

Figura 3.19- Distribuição de poços na área de estudo classificados de acordo com a disponibilidade de dados de vazão 
Considerando que existem diferenças significativas no padrão de funcionamento de poços de abastecimento público e poços para usos domésticos, comerciais e industriais, as estimativas do volume explotado foram calculadas distintamente para dois grupos de poços, sendo os de abastecimento público e dos demais tipos de uso. A Figura 3.20 demonstra a distribuição dos dados de vazão, conforme as categorias definidas anteriormente, separadas para os poços de abastecimento público e para as demais finalidades de uso. Os poços elencados no grupo dos demais usos são, em sua grande maioria, de propriedade privada.

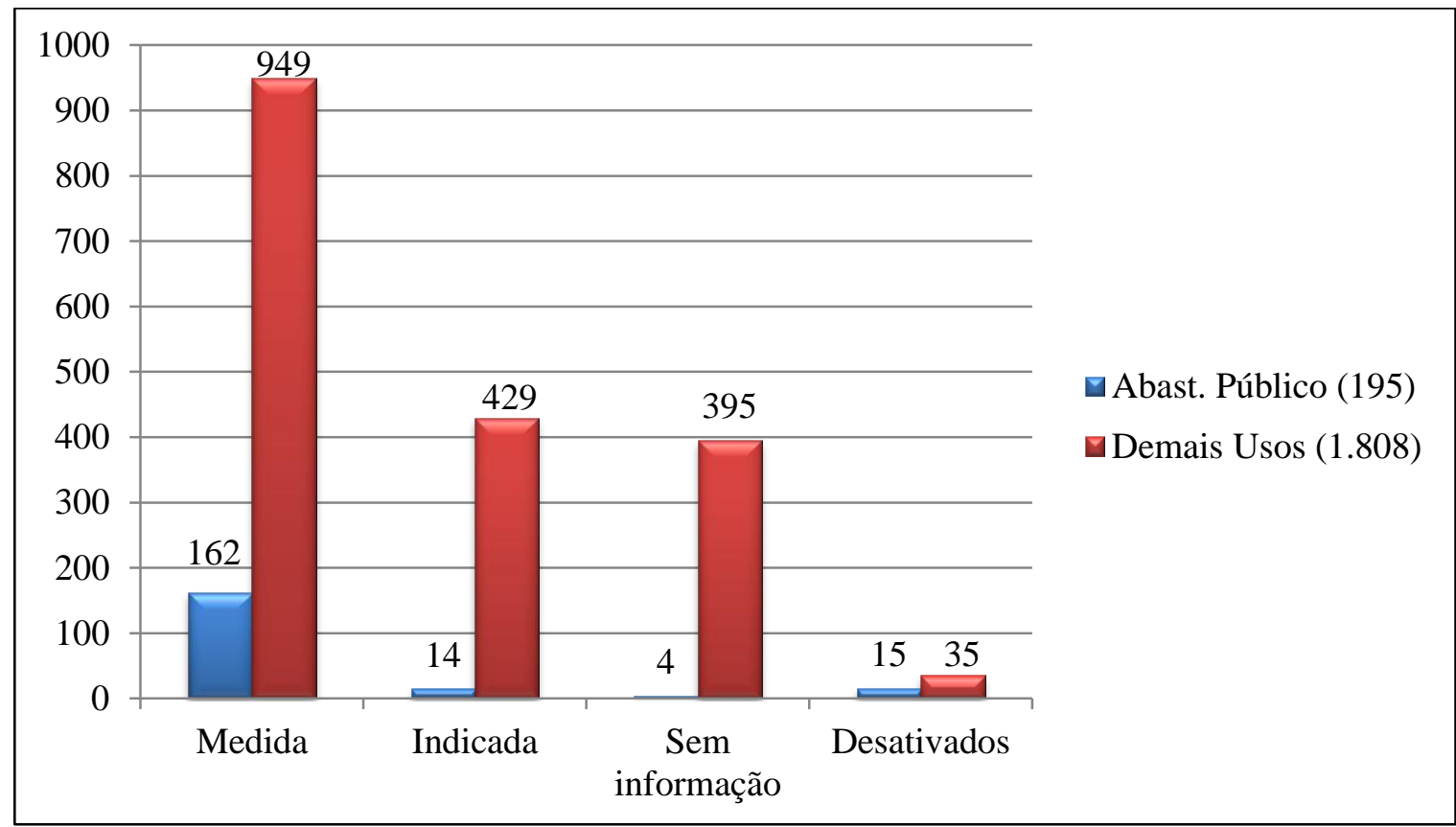

Figura 3.20- Disponibilidade de dados de vazão por categoria para os poços de abastecimento público e para as demais finalidades

No uso para o abastecimento público, a medição da vazão de produção ocorre em $90 \%$ dos poços em operação, de acordo com os dados do cadastro (DAEE, 2008). Estes totalizam 162 poços que explotam $1.363 \times 10^{3} \mathrm{~m}^{3} / \mathrm{mês}$ (1,36 milhão de metros cúbicos por mês). Nestes mesmos poços também estavam disponíveis os dados de vazão indicada, com valor médio de $19,4 \mathrm{~m}^{3} / \mathrm{h}$ que foi utilizado para se determinar o regime de bombeamento médio dos poços de abastecimento público, calculado em $15 \mathrm{~h} /$ dia.

O regime de bombeamento de $15 \mathrm{~h} /$ dia foi utilizado para determinar a explotação dos 14 poços que contam somente com os dados de vazão indicada (Figura 3.20). Estes 14 poços possuem vazão indicada média de $19,1 \mathrm{~m}^{3} / \mathrm{h}$ que, multiplicada pelo regime de $15 \mathrm{~h} / \mathrm{dia}$, foi calculada a explotação de $120 \times 10^{3} \mathrm{~m}^{3} / \mathrm{mês}$.

Desse modo, obteve-se a explotação de $1.483 \times 10^{3} \mathrm{~m}^{3} / \mathrm{mês}$ para os 176 poços de abastecimento público com dados de vazão medida e indicada. A média aritmética foi 
utilizada para se determinar o volume explotado por poço de abastecimento público, calculado em $8,4 \times 10^{3} \mathrm{~m}^{3} /$ mês. Este valor foi atribuído aos 4 poços de abastecimento que não possuem qualquer informação de vazão no cadastro, determinando-se um volume explotado por estes poços de $34 \times 10^{3} \mathrm{~m}^{3} / \mathrm{mês}$.

O método utilizado na estimativa da explotação do $\mathrm{SAB}$ pelos poços de abastecimento público em SJRP calculou um volume de retirada de $1.517 \times 10^{3} \mathrm{~m}^{3} / \mathrm{mês}$ efetuado pelos 180 poços do Semae em operação, de acordo com os dados do DAEE (2008).

No grupo de poços dos demais usos, os dados de vazão medida estão presentes em 949 poços (Figura 3.20), que representam $52 \%$ dos poços deste grupo. São explotados $428 \times 10^{3}$ $\mathrm{m}^{3} /$ mês pelos 949 poços, conforme dados de medição.

No cadastro, existem 429 poços de usos diversos que possuem dados de vazão indicada (Figura 3.20), nos quais, também estão informados os respectivos regimes de bombeamento. Desse modo, em todos os 429 poços foram obtidos os volumes mensais explotados, calculando-se um total de $1.718 \times 10^{3} \mathrm{~m}^{3} / \mathrm{mês}$.

No entanto, ao comparar a explotação obtida pelas vazões indicadas com os volumes medidos, notou-se forte discrepância entre os valores. Este fato motivou uma análise com 74 poços que possuem ambos os dados de vazões (medida e indicada). A Figura 3.21 permite observar que as explotações obtidas com os dados de vazão indicada estão superestimadas em relação aos volumes efetivamente explotados por estes poços, de acordo com as medições. As variações entre os dados das vazões medida e indicada de cada poço possuem taxa média de variação de $75 \%$.

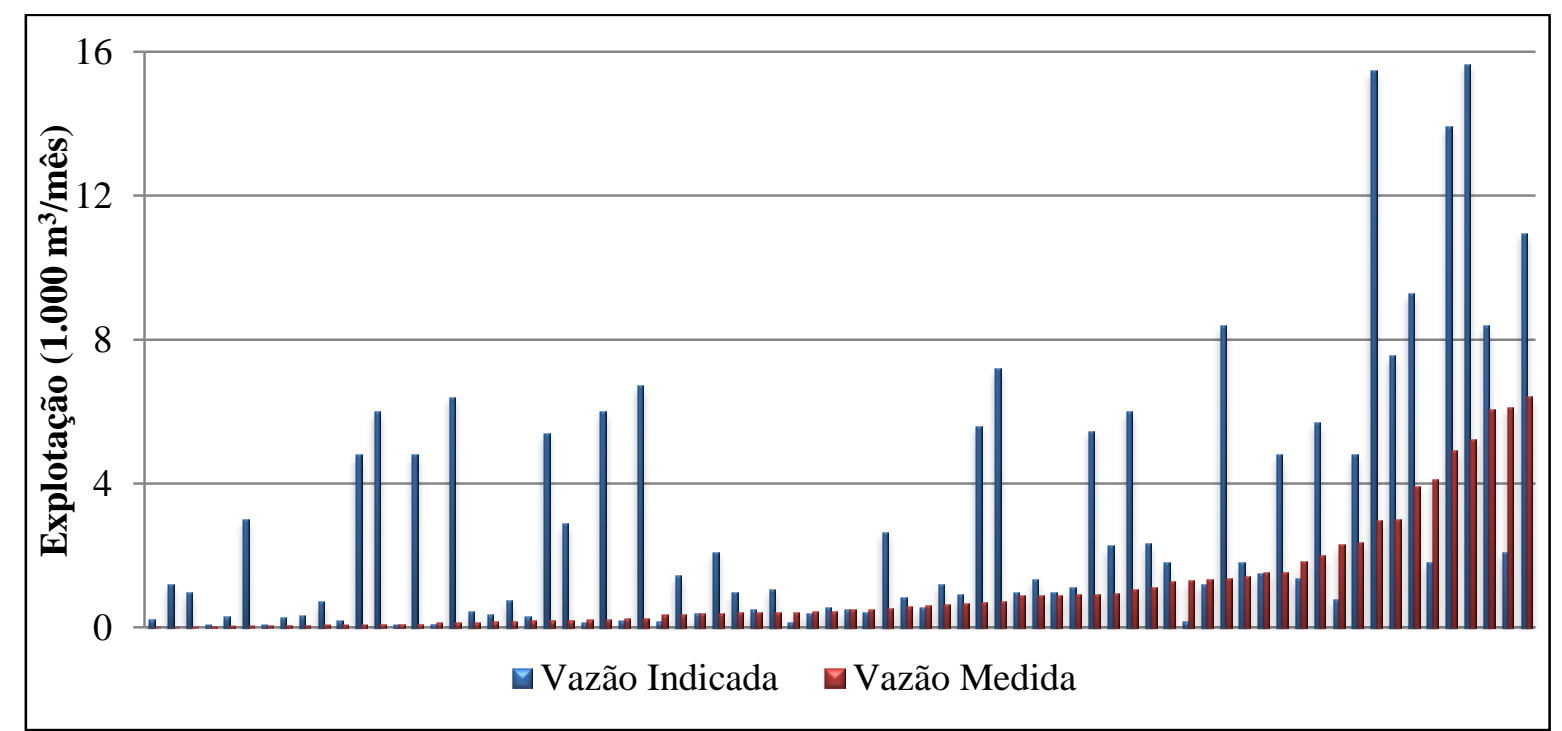

Figura 3.21- Análise em 74 poços das explotações calculadas com dados de vazão indicada compradas às explotações obtidas com as vazões medidas 
A partir da análise discutida acima, foi ajustado, em 75\%, o valor da explotação dos 429 poços com dados de vazão indicada, ou seja, foi considerada uma explotação de $1.289 \times 10^{3} \mathrm{~m}^{3} /$ mês para este elenco de poços.

A média do volume explotado pelos 1.378 poços com dados de vazão medida e indicada, no valor de $1,246 \times 10^{3} \mathrm{~m}^{3} /$ mês $\left(1.246 \mathrm{~m}^{3} /\right.$ mês), foi utilizada para determinar a explotação feita pelos 395 poços do cadastro sem informação de vazão, calculada em $492 \times 10^{3}$ $\mathrm{m}^{3} / \mathrm{mês}$.

Utilizando-se o procedimento descrito anteriormente, foi calculado um volume explotado de $2.210 \times 10^{3} \mathrm{~m}^{3} /$ mês pelos 1.773 poços para as diversas finalidades de uso da água.

A Tabela 3.4 mostra os valores calculados, segundo os critérios estabelecidos com base na disponibilidade de dados de vazão, distintamente para o abastecimento público e demais usos, conforme descrito anteriormente, bem como apresenta o volume total explotado do SAB em SJRP pelos 1.953 poços em operação, de acordo com os dados disponibilizados pelo DAEE (2008).

Tabela 3.4 - Volumes explotados do SAB em SJRP por tipo de uso e categorias de dados de vazão

\begin{tabular}{|c|c|c|}
\hline Tipificação & $\mathrm{N}^{\mathrm{o}}$ de Poços & Vol. Explotado (m³/mês) \\
\hline \multicolumn{3}{|l|}{ Abastecimento Público } \\
\hline Vazões Medidas & 162 & 1.363 .297 \\
\hline Vazões Indicadas & 14 & 120.024 \\
\hline Sem dados de Vazão & 4 & 33.712 \\
\hline Total - Abast. Público & 180 & 1.517 .033 \\
\hline \multicolumn{3}{|l|}{ Demais usos } \\
\hline Vazões Medidas & 949 & 428.965 \\
\hline Vazões Indicadas & 429 & 1.288 .514 \\
\hline Sem dados de Vazão & 395 & 492.170 \\
\hline Total - Demais usos & 1.773 & 2.209 .649 \\
\hline Explotação Total & 1.953 & 3.726 .682 \\
\hline
\end{tabular}

Os dados de vazão medida são obtidos e foram disponibilizados com periodicidade mensal. Desse modo, optou-se em manter a unidade de medida original, visando minimizar distorções dos valores, já que representam os dados de maior precisão utilizados nos cálculos 
da explotação. A explotação total do $\mathrm{SAB}$ na área de estudo foi calculada em $3.727 \times 10^{3}$ $\mathrm{m}^{3} / \mathrm{mês}$, o que representa um volume retirado anualmente do SAB de cerca de 45 milhões de metros cúbicos, ou ainda, equivalente a $122.521 \mathrm{~m}^{3} / \mathrm{dia}$ ou $1,42 \mathrm{~m}^{3} / \mathrm{s}$.

O gráfico da Figura 3.22 ilustra como os tipos de dados de vazão contribuem para o cálculo da explotação do SAB em SJRP, demonstrando os percentuais de participação de cada tipo de dado na estimativa total.

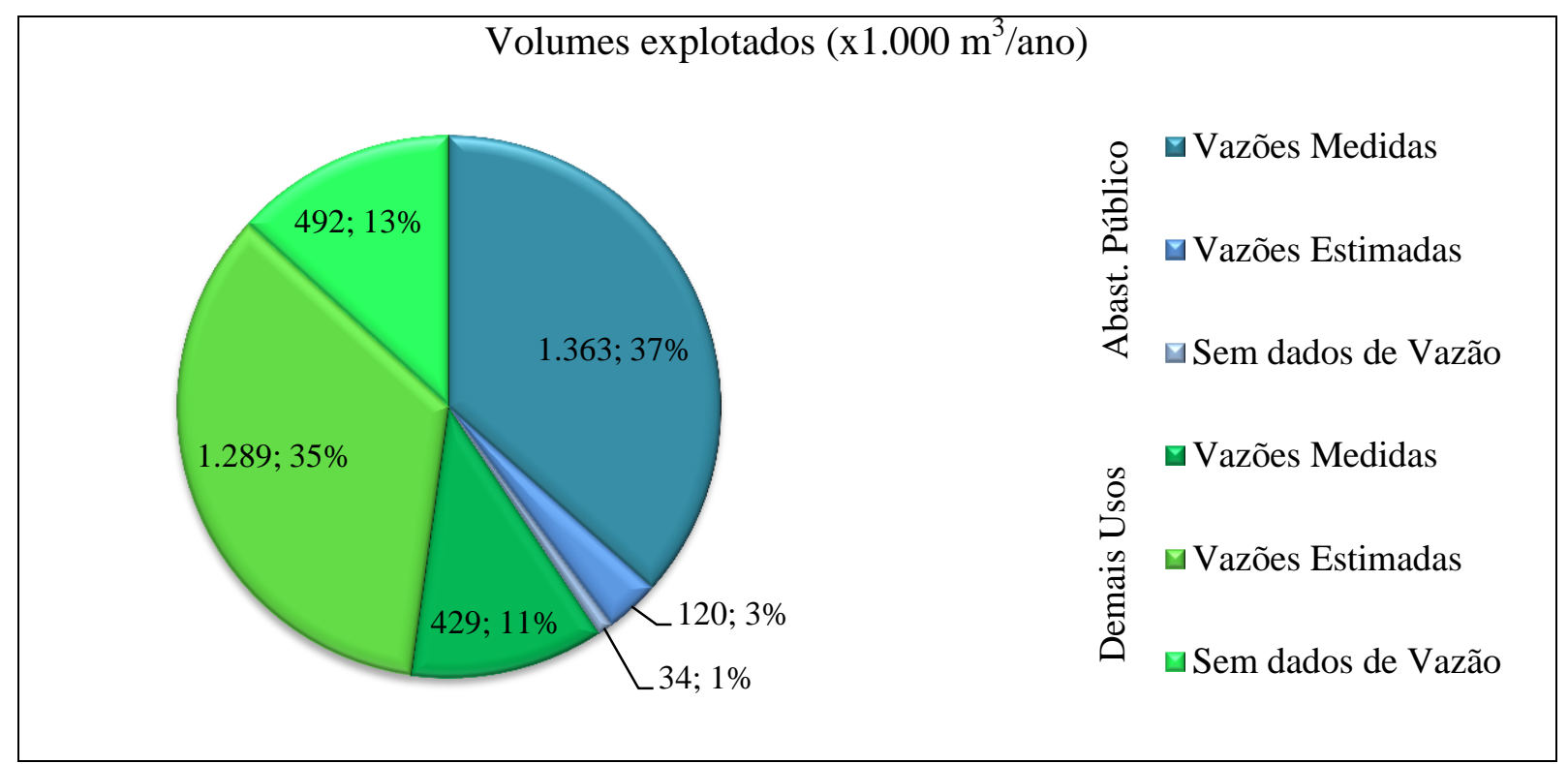

Figura 3.22- Gráficos dos volumes explotados do SAB em SJRP especificados pelo tipo uso e pelas categorias de dados de vazões

Nota-se que as vazões medidas representam $48 \%$ da explotação total calculada (Figura 3.22), configurando um diferencial desse município em relação ao nível de precisão da estimativa dos volumes explotados de águas subterrâneas.

A Figura 3.22 também demonstra que os demais usos, na grande maioria referente a poços particulares, representam quase $60 \%$ do volume total explotado do SAB.

As análises sobre a infraestrutura hídrica relacionada aos poços de captação do SAB em SJRP possuem características marcantes do modelo de desenvolvimento do uso das águas subterrâneas, destacando que: $82 \%$ dos poços não possuem outorga e estão em desacordo com a legislação vigente; cerca de $90 \%$ são poços particulares, em muitos casos, clandestinos, mostrando a descentralização e o baixo controle do uso do recurso hídrico subterrâneo; e os poços particulares contribuem com cerca de $60 \%$ de toda a explotação do SAB, contribuindo fortemente com o abastecimento de água. 


\subsection{O DESENVOLVIMENTO DO USO DAS ÁGUAS SUBTERRÂNEAS DO SAB}

As primeiras menções sobre a intensificação do uso da água subterrânea do SAB em SJRP ocorreram já no início da década de 80. Barcha (1980), em sua tese de livre docência, chamou a atenção para a proliferação de poços tubulares e para o uso das águas subterrâneas do Sistema Aquífero Bauru (SAB) como alternativa de suprimento para as crescentes demandas de uma região em forte crescimento econômico, social e demográfico. Naquele período, despertava-se o interesse da água subterrânea como uma fonte imediatamente disponível e de baixo custo.

Barcha (1980) estimou a existência de quase 400 poços em São José do Rio Preto e, obviamente, não havia menção a quaisquer problemas relacionados ao modelo de uso das águas subterrâneas.

O foco do trabalho de Barcha (1980) foi de avaliar as potencialidades e as heterogeneidades do SAB na região noroeste do Estado de São Paulo, também como subsídio ao aproveitamento hídrico desse manancial. Para tanto, foram utilizados dados provenientes de poços tubulares perfurados em SJRP e região.

Barcha (1992) estima a existência de 3.500 poços em operação no perímetro urbano de SJRP e enfoca a problemática da contaminação das águas subterrâneas do SAB por nitrato, na região central da cidade. O referido autor não aborda a temática sobre os índices de explotação e sobre os possíveis efeitos do uso intenso na potenciometria do SAB.

Deve-se destacar o crescimento de quase $800 \%$ na quantidade de poços, em 12 anos, segundo as estimativas apresentadas nos citados trabalhos (BARCHA, 1980; 1992).

Barcha (1998) efetua uma avaliação do abastecimento de água de SJRP, registrando que os dados do abastecimento público representa apenas uma parcela do suprimento total da cidade, complementado por uma rede de poços particulares, estimada no estudo em 3.500 poços. Nesse trabalho, é caracterizada a rede de poços particulares como 55\% para o atendimento de residências e condomínios (uso doméstico), $25 \%$, uso industrial e $20 \%$, uso comercial, sendo estimado um volume de captação de $110.000 \mathrm{~m}^{3} / \mathrm{dia}$, correspondente ao bombeamento em uma vazão média de $10 \mathrm{~m}^{3} / \mathrm{h}$ com regime operacional de 2 a $3 \mathrm{~h} / \mathrm{dia}$. Desse modo, é avaliado um suprimento total de $243.000 \mathrm{~m}^{3} /$ dia, provenientes do abastecimento público e dos poços particulares do SAB com a estimativa de perdas gerais de todo o sistema da ordem de $51 \%$. 
Apesar de o trabalho não efetuar uma abordagem que forneça as evidências necessárias, Barcha (1998) conclui sobre a existência de superexplotação do SAB na zona urbana de SJRP, indicando também que o mesmo ocorre em outras sedes urbanas da região.

Oliveira (2002) desenvolveu um modelo numérico para a simulação do comportamento do fluxo subterrâneo do SAB em SJRP, destacando a importância e a aplicação da ferramenta de modelação na gestão dos recursos hídricos subterrâneos. A modelação foi desenvolvida em uma área abrangendo toda a zona urbana de SJRP, sendo simulada uma explotação equivalente a $5.000 \mathrm{~m}^{3} / \mathrm{h}$ que, segundo o autor, ocorreria por 3.900 poços, sendo 400 poços cadastrados e 3.500 poços clandestinos. O mapa potenciométrico gerado pelo aplicativo de modelação indicou a ocorrência de intensos rebaixamentos, da ordem de $120 \mathrm{~m}$, na região central do perímetro urbano.

O resultado alcançado pela modelação numérica desenvolvida por Oliveira (2002) permitiu, pela primeira vez, a verificação dos efeitos do intenso uso das águas subterrâneas em uma escala apropriada e, principalmente, demonstrando a ocorrência dos rebaixamentos dos níveis potenciométricos apontados pelo órgão gestor dos recursos hídricos.

As estimativas sobre a quantidade de poços existentes em SJRP, indicadas por Oliveira (2002), são quase $100 \%$ superiores aos dados adotados no presente estudo, embora a estimativa do volume explotado seja, em ordem de grandeza, compatível com as calculadas nesta pesquisa.

Lima (2004) realizou uma avaliação hidrogeológica do SAB em SJRP, através da análise de dados provenientes de um elenco de 355 poços. $\mathrm{O}$ autor conclui sobre a existência da interferência entre poços e superexplotação na zona urbana, a partir da variação dos níveis estáticos de poços próximos, situados em mesma cota topográfica. $\mathrm{O}$ estudo traz também uma estimativa da explotação de $37.032 \mathrm{~m}^{3} /$ dia, considerando a vazão média de $17,38 \mathrm{~m}^{3} / \mathrm{h}$ e o regime de explotação médio de 6 h/dia, significando uma explotação média de 104,31 m3/dia para cada um dos 355 poços adotados no cálculo.

Considerando a explotação média por poço estimada por Lima (2004) e replicando ao universo de 1.953 poços em operação adotados neste trabalho, seria estimado um volume de explotação de $203.000 \mathrm{~m}^{3} /$ dia. Esse volume seria quase $100 \%$ superior ao calculado no presente estudo.

O estudo hidrogeológico contratado pelo DAEE e executado pela empresa Servmar Ambiental (DAEE, 2008), alcançou um potencial avanço ao processo de gestão do cenário de uso das águas subterrâneas do SAB em SJRP. Destacam-se como efetivos ganhos gerados com esse trabalho a ampliação, a organização, a digitalização, a consistência e o 
georreferenciamento de uma enorme quantidade de dados, principalmente sobre poços existentes em SJRP.

O cadastro de poços produtores elaborado no estudo (DAEE, 2008) possui 2.003 poços registrados e, ainda que não contenha a totalidade dos poços existentes em SJRP, representa a consolidação de um cenário que contava com uma mesma estimativa imutável desde 1992, aparentemente superestimada, de 3.500 poços na zona urbana de SJRP. Destacase, ainda, que o referido cadastro de poços foi a principal fonte de dados para o desenvolvimento da presente pesquisa.

O estudo hidrogeológico (DAEE, 2008) também incluiu o balanço hídrico na área de interesse que foi realizado por dois métodos distintos, sendo um por modelação numérica de fluxo subterrâneo e outro por método analítico hidrológico com referência ao nível de base da microbacia hidrográfica do rio Preto. Os resultados do balanço hídrico permitiram, por exemplo, definir a recarga e o volume de água em circulação, a partir do qual foi determinada a disponibilidade hídrica do SAB na área de estudo.

A modelação numérica do estudo do DAEE (2008) foi calibrada para um cenário de equilíbrio dinâmico natural, ou seja, sem a interferência de bombeamentos e, em segundo estágio, foi simulada a explotação de um volume de $97.945 \mathrm{~m}^{3} /$ dia a partir de 1.888 poços existentes na área do modelo, segundo dados do cadastro. A simulação do bombeamento demonstrou fortes rebaixamentos na potenciometria do $\mathrm{SAB}$, na zona central do perímetro urbano de SJRP.

O mapa potenciométrico gerado pelo modelo numérico para ambos o cenário de explotação foi adotado nesta pesquisa como um dos cenários avaliados na determinação dos efeitos do uso intenso da água subterrânea no custo de energia elétrica consumida no bombeamento dos poços.

Destaca-se também a imensa contribuição à gestão dos recursos hídricos subterrâneos alcançada pelo estudo (DAEE, 2008). Os resultados obtidos com balanço hídrico e o georreferenciamento das informações permitiram determinar uma proposta de área de restrição e controle, embasada em um zoneamento no qual a explotação ocorre em volume superior a $75 \%$ da disponibilidade hídrica calculada, sendo que, em locais da região central da zona urbana de SJRP, a explotação ocorre em níveis superiores ao dobro da disponibilidade.

A disponibilidade hídrica calculada no estudo (DAEE, 2008) foi de $437,4 \mathrm{~m}^{3} / \mathrm{dia} / \mathrm{km}^{2}$ e foi considerada como um volume de explotação sustentável do SAB na região. Considerando a área de estudo do DAEE (2008), de $728 \mathrm{~km}^{2}$, que é a mesma adotada nesta pesquisa, a disponibilidade hídrica calculada representa um volume total de $318.427 \mathrm{~m}^{3} / \mathrm{dia}$, 
passível de ser explotado sustentavelmente do SAB. Esse montante corresponde a quase o dobro da estimativa do volume atualmente explotado.

Em contribuição à gestão dos recursos hídricos, o estudo do DAEE (2008), ainda, elencou medidas de controle adicionais aos requisitos legais existentes, a serem implementadas nas áreas denominadas de "Zonas de Ações Prioritárias". As medidas de controle sugeridas previam, entre outras ações, o tamponamento de poços em condições construtivas inadequadas e/ou desativados, o periódico monitoramento da qualidade das águas a ser conduzido pelo usuário/proprietário do poço e a ampliação das informações sobre os poços em operação.

A base de dados digital produzida no estudo, disponível em versão editável, permite novas avaliações, diversas aplicações e, sobretudo, representa para os órgãos gestores dos recursos hídricos e do meio ambiente uma importante ferramenta de trabalho no armazenamento de informações, bem como de planejamento das ações de controle. Esta pesquisa vivenciou uma experiência compatível ao discutido acima, pois com os mesmos dados do estudo do DAEE (2008) alcançou novas observações e conclusões sobre o cenário de uso dos recursos hídricos subterrâneos do SAB em SJRP.

Wendland et al. (no prelo) revisitaram os dados do modelo numérico de fluxo subterrâneo desenvolvido nos estudos hidrogeológicos do DAEE (2008), focando a demonstração dos aspectos da construção e do desenvolvimento da modelação numérica.

Atualmente, uma das linhas de pesquisa do CEPAS estuda com diferentes abordagens o modelo de uso das águas subterrâneas do SAB em SJRP, visando à avaliação da problemática do uso intenso das águas subterrâneas em áreas urbanas com foco na identificação de ferramentas e contribuições à gestão dos recursos hídricos subterrâneos. Neste contexto, foi desenvolvido presente estudo, bem como as simulações por modelação numérica de fluxo subterrâneo de diferentes cenários de explotação que foram utilizadas para a determinação dos rebaixamentos dos níveis potenciométricos do SAB. 


\subsection{A EXPLOTAÇÃO DO SAB SIMULADA POR MODELAÇÃO NUMÉRICA}

O modelo de uso das águas subterrâneas do SAB em SJRP provocou efeitos de rebaixamento dos níveis potenciométricos, conforme comprovado em diversos estudos existentes (OLIVEIRA, 2002; LIMA, 2004; DAEE, 2008; WENDLAND et al., no prelo), com destaque aos resultados alcançados em modelações numéricas que demonstraram intensos rebaixamentos dos níveis potenciométricos, sobretudo na região central da cidade, onde ocorre a maior densidade de poços.

Os modelos numéricos de fluxo do aquífero desenvolvidos para a simulação de condições de explotação do SAB em SJRP fornecem as profundidades do nível de água resultantes da influência do bombeamento nas diferentes localidades do modelo. Desse modo, demonstrando tanto os rebaixamentos provocados pela interferência entre poços, nos locais com intensa explotação, quanto leves influências, ainda incipientes, nas áreas com menores densidades de poços e menores vazões de explotação.

Considerando o interesse do presente estudo, foram adotados resultados de modelações numéricas existentes, objetivando a identificação do nível potenciométrico do SAB em diversas condições de explotação, visando à avaliação da influência de diferentes regimes de bombeamento no custo de energia elétrica para a captação das águas subterrâneas.

Os mapas potenciométricos de modelos numéricos de fluxo subterrâneo do SAB adotados nesta pesquisa foram: o cenário de bombeamento calculado nos estudos hidrogeológicos do DAEE (2008) e Wendland et al. (no prelo) e cenários modelados nos trabalhos realizados por Carvalho (2012) e Carvalho et al. (em preparação), no âmbito das pesquisas sobre a gestão das águas subterrâneas em SJRP, desenvolvidas no LAMO/CEPAS.

A modelação numérica dos trabalhos do DAEE (2008) e Wendland et al. (no prelo) foi desenvolvida com a utilização do aplicativo SPA - Simulação de Processos em Aquíferos, desenvolvido pelo Laboratório de Hidráulica Computacional da Escola de Engenharia de São Carlos e o modelo numérico apresentado por Carvalho (2012) e Carvalho et al. (em preparação) foi gerado o uso do aplicativo Visual MODFLOW, versão 4.3 (GUIGUER; FRANZ 1996 apud CARVALHO, 2012). Ambos os modelos foram calibrados e operados em estado estacionário e, desse modo, os resultados representam a "fotografia" do equilíbrio dinâmico alcançado nas condições modeladas.

${ }^{1}$ GUIGUER, N; e FRANZ, T. 1996. Visual MODFLOW. User's manual. Waterloo Hidrogeologic Inc., Waterloo, Canadá. 176 pp. 
A Figura 3.23 ilustra a disposição dos referidos modelos numéricos na área de estudo e destaca a sobreposição de ambos os modelos. O modelo do DAEE (2008) e Wendland et al. (no prelo) foi desenvolvido em uma área de abrangência de $385 \mathrm{~km}^{2}$ e a modelação de Carvalho (2012) possui $355 \mathrm{~km}^{2}$. A área de interseção dos modelos possui $340 \mathrm{~km}^{2}$ e foi utilizada para a comparação dos cenários modelados, na avaliação dos custos do consumo de energia elétrica na explotação das águas subterrâneas.

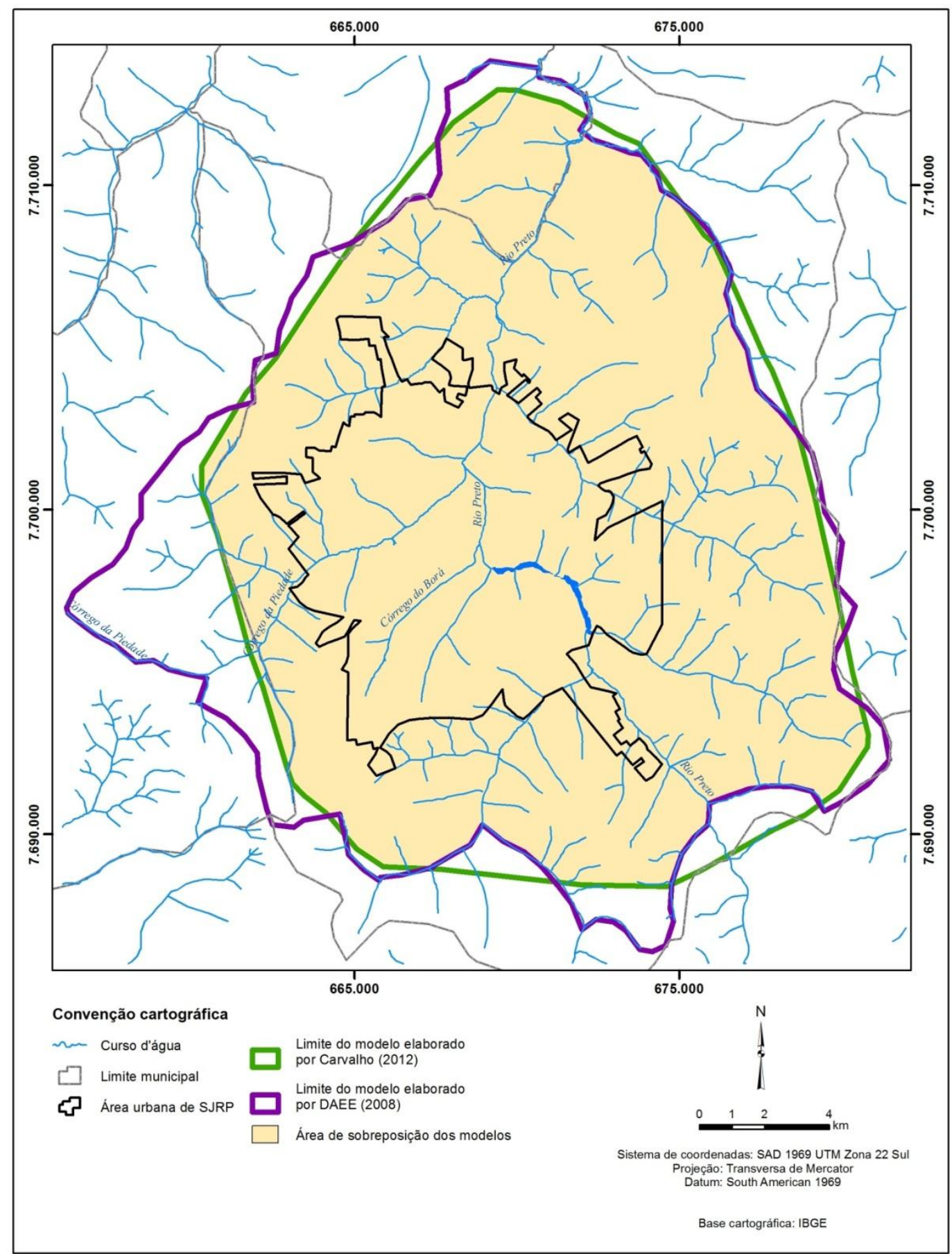

Figura 3.23 - Localização das áreas dos modelos numéricos de fluxo subterrâneo do SAB na área de estudo com destaque ao contorno da intersecção de ambos os modelos 
Ressalta-se que na construção dos modelos numéricos adotados foram utilizados parâmetros do aquífero concordantes com os apresentados nesta pesquisa, pois se basearam em dados disponíveis no cadastro de poços produtores do DAEE (2008).

Os trabalhos do DAEE (2008) e Wendland et al. (no prelo) possuem a modelação numérica do fluxo subterrâneo simulando a condição natural do SAB em SJRP, ou seja, sem a influência de bombeamentos. Esse cenário é resultante do modelo calibrado a partir de dados de níveis estáticos de poços instalados nas décadas de 60 e 70 e permite realizar a comparação da potenciometria em condições naturais de fluxo com os diferentes cenários com a influência de bombeamentos.

Os dados da potenciometria das condições naturais de fluxo subterrâneo demonstram que a profundidade média do nível de água é de 15,91 m e a profundidade máxima é de 38,62 m. A Figura 3.24, a seguir, demonstra o cenário descrito acima, sem a interferência de bombeamentos.

No cenário de fluxo natural (Figura 3.24) as equipotenciais variam de $560 \mathrm{~m}$ a cerca de $450 \mathrm{~m}$. As cotas potenciométricas mais elevadas estão situadas principalmente nas áreas de recarga, próximos aos divisores de água da microbacia hidrográfica do rio Preto e os menores potenciais estão situados nas áreas de descargas, caracterizadas pelos rios e córregos com condição de efluência ao aquífero. Destaca-se que, na região central de SJRP, as cotas potenciométricas variam de 520 a $490 \mathrm{~m}$.

A Figura 3.25 apresenta o mapa potenciométrico referente à modelação do cenário de uso das águas subterrâneas, correspondente à base de dados de 2008, considerando a explotação de cerca de $98.000 \mathrm{~m}^{3} /$ dia. Esse cenário é equivalente à explotação do SAB calculada no presente estudo, sendo que a variação de cerca de $20 \%$ entre os volumes de explotação calculado e modelado deve-se à cobertura parcial do modelo, em relação à área total do estudo, e por diferenças advindas dos métodos de cálculo do volume explotado adotados pelos estudos.

A caracterização do uso da água subterrânea efetuada neste estudo está plenamente representada no modelo que resultou a potenciometria da Figura 3.25, pois utiliza a mesma base de dados do cadastro de poços do DAEE (2008) e, desse modo, considera os tipos de usos, quantidades de poços, regimes e volumes de explotação apresentados e discutidos no presente trabalho. 


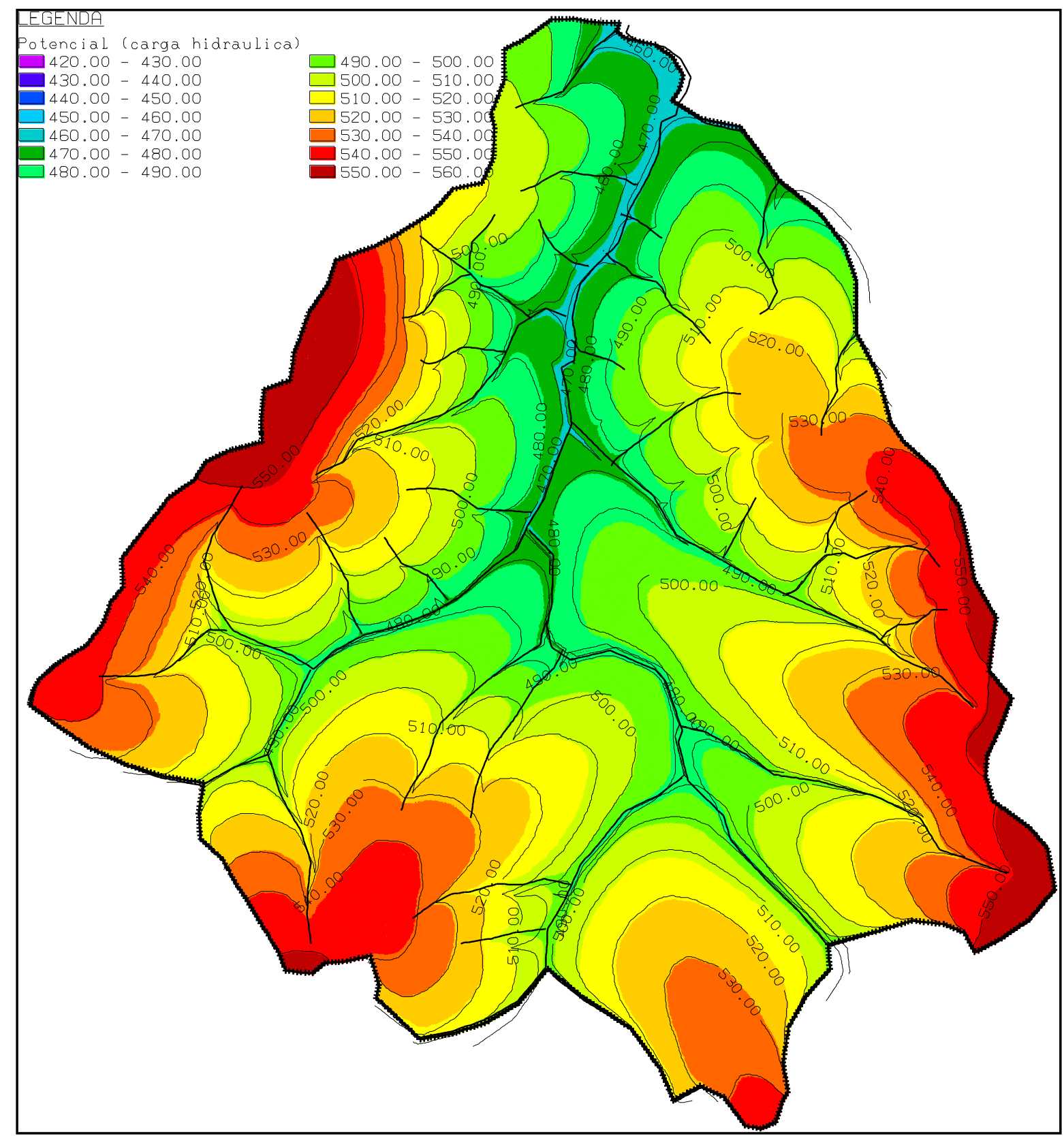

Figura 3.24 - Mapa potenciométrico gerado por modelo numérico de fluxo subterrâneo do SAB em SJRP com a simulação do fluxo natural sem a influência de bombeamentos (DAEE, 2008) 
Em comparação do cenário do modelado na Figura 3.25 com a condição natural de fluxo (Figura 3.24), observam-se fortes abatimentos das cotas potenciométricas ocorridos na região central da cidade, onde as equipotenciais rebaixaram de patamares em torno de $500 \mathrm{~m}$ para cerca de $430 \mathrm{~m}$. Essas localidades possuem as maiores densidades de poços, bem como elevadas taxas de explotação.

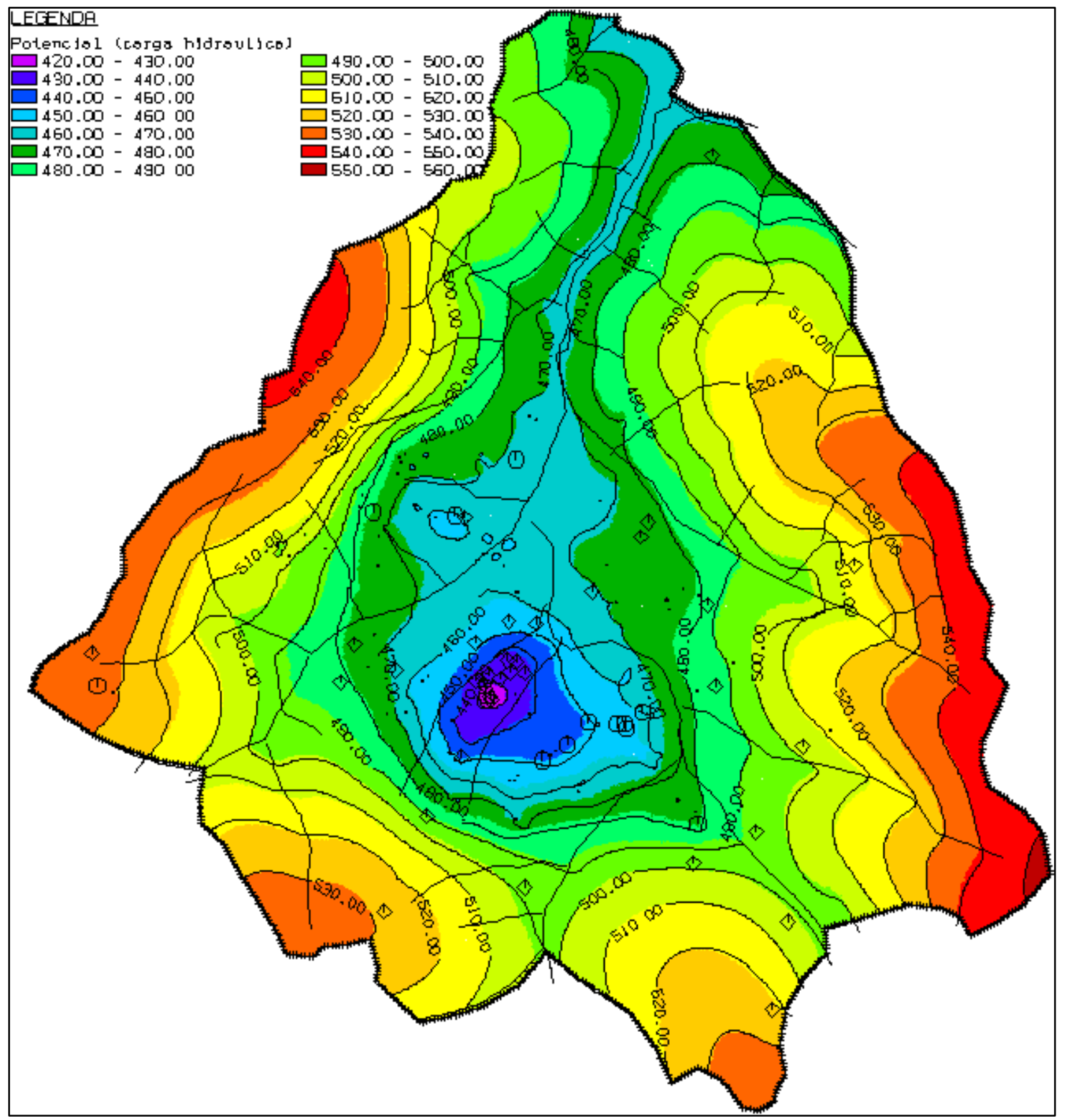

Figura 3.25 - Mapa potenciométrico gerado por modelo numérico de fluxo subterrâneo do SAB em SJRP, referente à explotação de $98.000 \mathrm{~m}^{3} /$ dia (DAEE, 2008) 
A seguir serão apresentados três diferentes cenários de explotação das águas subterrâneas do SAB em SJRP, obtidos a partir da modelação numérica apresentada por Carvalho (2012) e Carvalho et al. (em preparação).

A Figura 3.26 apresenta o mapa potenciométrico da modelação numérica simulando um cenário de explotação de cerca de $160.000 \mathrm{~m}^{3} /$ dia. Esse cenário é cerca de $40 \%$ superior aos volumes de explotação calculados no presente estudo. O volume de explotação modelado foi alcançado atribuindo-se uma mesma taxa de aumento de vazão para todos os poços existentes na área do modelo (Carvalho, 2012).

Deve-se ressaltar que os poços incluídos na área do modelo são os mesmos disponíveis no cadastro do DAEE (2008).

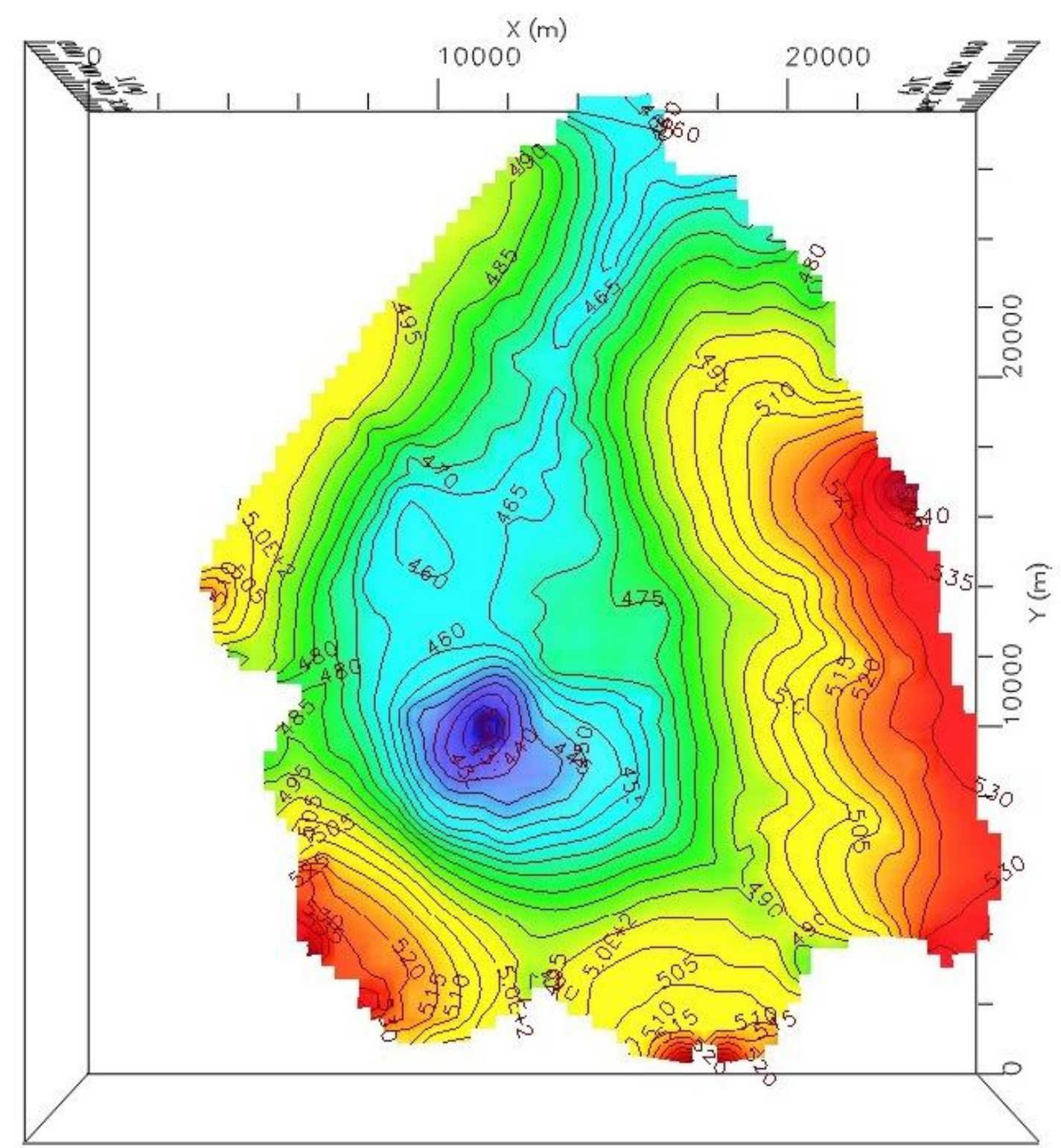

Figura 3.26 - Mapa potenciométrico gerado por modelo numérico de fluxo subterrâneo do SAB em SJRP, referente à explotação de $160.000 \mathrm{~m}^{3} /$ dia (Carvalho, 2012) 
O resultado da modelação numérica da Figura 3.26 corresponde a um cenário hipotético de bombeamento, uma vez que foi arbitrado o volume explotado pelos poços em operação registrados no cadastro. Entretanto, considera-se que o volume de explotação modelado na Figura 3.26 represente uma estimativa da condição atual de bombeamento das águas subterrâneas do SAB em SJRP, na qual, o aumento da explotação representa a parcela de poços existentes, mas que não estão incluídos no cadastro do DAEE (2008), bem como, o natural aumento do número de poços e das vazões de explotação de 2008 até o momento.

O cenário modelado na Figura 3.26 intensifica ainda mais as depleções dos níveis potenciométricos na região central da cidade, atingindo cotas inferiores a $420 \mathrm{~m}$, estendendo também os efeitos dos rebaixamentos para regiões circunvizinhas a leste e a norte.

A Figura 3.27 apresenta o mapa potenciométrico da modelação numérica simulando um cenário hipotético de explotação de cerca de $240.000 \mathrm{~m}^{3} /$ dia. Esse cenário simula uma explotação 50\% superior ao modelado na Figura 3.26 e cerca de $110 \%$ superior aos volumes de explotação calculados no presente estudo. Neste cenário, o resultado da modelação também considerou uma mesma taxa de aumento de vazão para todos os poços do cadastro do DAEE (2008) existentes na área do modelo, totalizando a vazão de explotação arbitrada em $240.000 \mathrm{~m}^{3} / \mathrm{dia}$ (Carvalho, 2012).

Na Figura 3.27, os intensos rebaixamentos dos níveis potenciométricos avançam para além da região central da cidade, em direção a norte e a leste, onde as cotas rebaixam cerca de $30 \mathrm{~m}$. Na região central de SJRP as cotas potenciométricas atingem valores inferiores a 400 $\mathrm{m}$, representando, desse modo, rebaixamentos superiores a $100 \mathrm{~m}$, se comparado com as condições naturais de fluxo (Figura 3.24). 


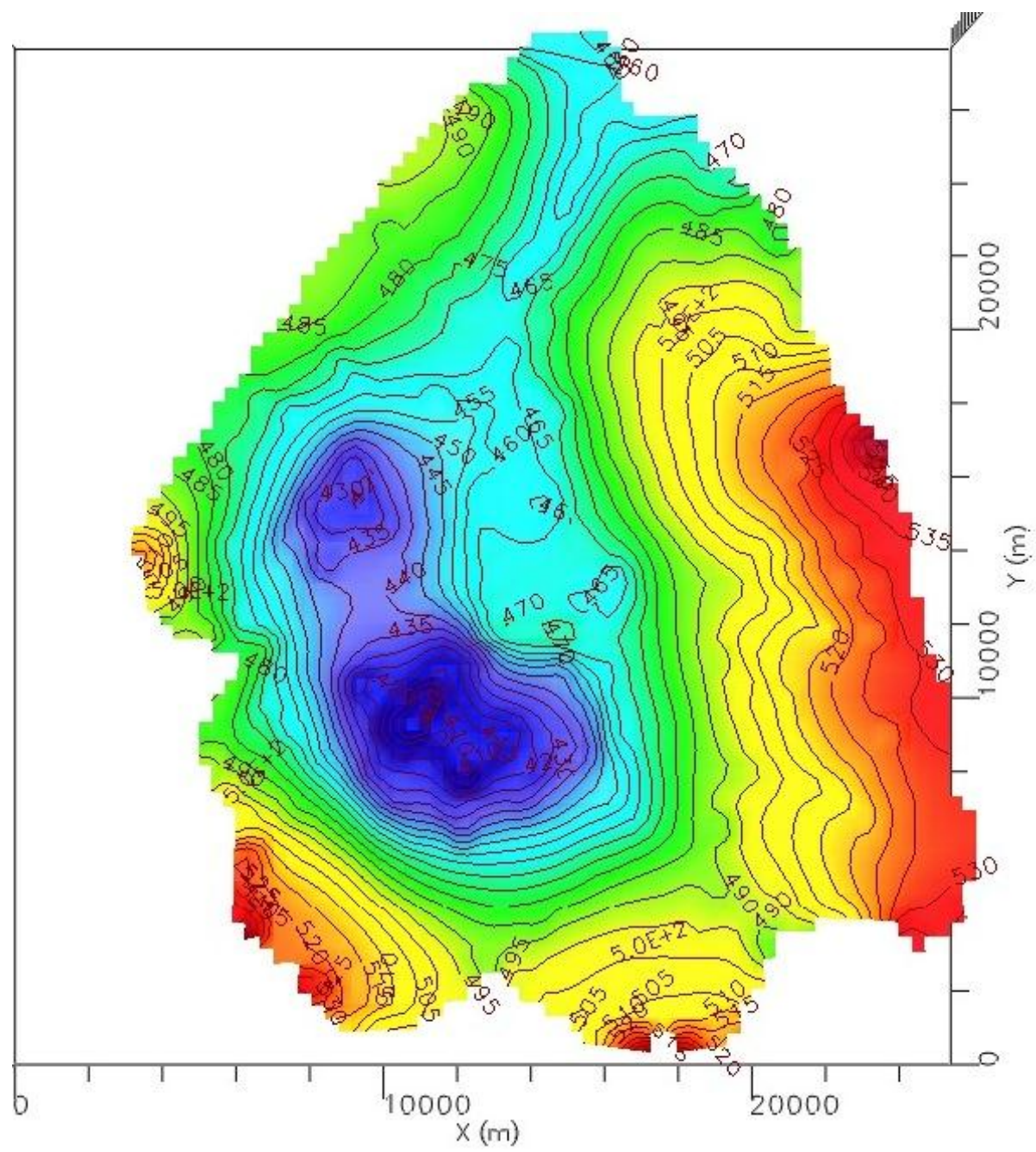

Figura 3.27 - Mapa potenciométrico gerado por modelo numérico de fluxo subterrâneo do SAB em SJRP, referente à explotação de $240.000 \mathrm{~m}^{3} /$ dia (Carvalho, 2012)

A Figura 3.28 apresenta o mapa potenciométrico referente à simulação de um cenário hipotético no qual foi considerado somente a explotação dos poços públicos. Este cenário corresponde a uma explotação de cerca de $47.000 \mathrm{~m}^{3} /$ dia que é o volume captado pelos 180 poços de abastecimento público em operação na área do modelo, com base nos dados de vazão de explotação do cadastro do DAEE (2008).

O propósito dessa simulação é avaliar, comparativamente ao demais cenários, o efeito da influência dos usuários privados, interferindo na depleção dos níveis potenciométricos para o uso público e, desse modo, permitir a análise de possíveis externalidade geradas pelos usos privados à coletividade.

O resultado da simulação demonstrada na Figura 3.28 permite constatar que, nestas condições de explotação, os rebaixamentos dos níveis potenciométricos existem, mas são bem menores que os evidenciados quando a explotação é realizada conjuntamente por poços públicos e privados. 
Nota-se que as cotas potenciométricas na região central da cidade rebaixaram cerca de 10 m em relação ao cenário de fluxo natural (Figura 3.24) e estão entre 70 e 90 m mais rasas que os cenários registrados nas Figuras 3.25 e 3.26.

A análise comparativa entre os cenários citados anteriormente permite constatar a forte interferência que os poços privados exercem sobre o uso público dos recursos subterrâneos do SAB em SJRP.

A análise comparativa entre todos os cenários modelados permite constatar que, nos locais com as maiores densidades de poços, as interferências entre poços são maiores, ocasionando as maiores depleções dos níveis potenciométricos. Nota-se também que o aumento da explotação, como esperado, intensifica os efeitos de rebaixamento dos níveis de água no aquífero.

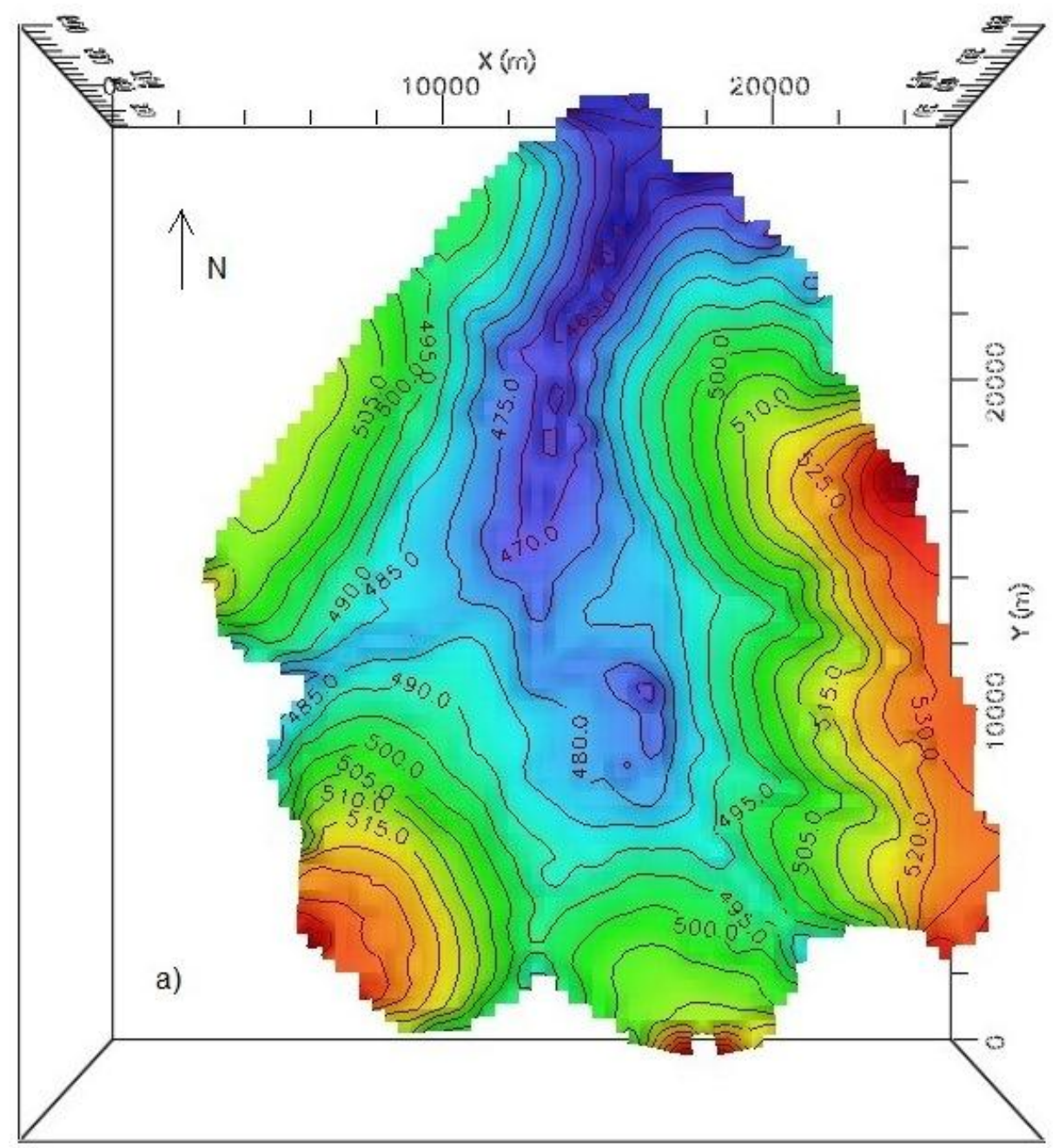

Figura 3.28 - Mapa potenciométrico gerado por modelo numérico de fluxo subterrâneo do SAB, referente à explotação de $47.000 \mathrm{~m}^{3} /$ dia realizada somente pelos poços de abastecimento público (Carvalho, 2012) 


\section{MATERIAIS E MÉTODOS}

O desenvolvimento desta pesquisa foi alicerçado em dados existentes e na produção de resultados teóricos para atingir ao objetivo proposto.

A fase inicial deste estudo contou com levantamento da bibliografia e dos dados sobre a temática da pesquisa, a partir dos quais foram definidos os fundamentos teóricos do desenvolvimento da pesquisa e os parâmetros de interesse.

A fundamentação teórica foi embasada nos conceitos sobre a explotação de água subterrânea e as respostas do aquífero à extração com efeito aos fatores que influenciam o consumo de energia elétrica no bombeamento. Essas bases teóricas levaram à adoção da equação do cálculo da potência hidráulica para a determinação do consumo de energia elétrica. Desse modo, os parâmetros de interesse definidos para o cálculo do consumo foram: a vazão de explotação; a altura manométrica e o rendimento dos sistemas de bombeamento.

Os parâmetros de interesse são dados associados à operação dos poços de captação das águas subterrâneas. Desse modo, o cadastro de poços cedido pelo DAEE para esta pesquisa foi a principal fonte desses dados.

A segunda fase de desenvolvimento contemplou a análise do conteúdo do cadastro e identificação dos dados disponíveis ou a definição dos passos necessários à obtenção dos dados sobre os parâmetros de interesse.

A análise ao conteúdo do cadastro identificou que parte dos poços contavam com dados consistentes sobre todos os parâmetros que possibilitavam o cálculo do consumo de energia elétrica no bombeamento. Entretanto, este elenco não seria suficiente para a avaliação de todo o cenário de explotação do SAB em SJRP.

A partir dessa etapa, o desenvolvimento da pesquisa seguiu trajetórias paralelas para a determinação dos dados de vazão de explotação, altura manométrica e rendimento dos sistemas de bombeamento, visando suprir a deficiência de dados do cadastro de poços sobre os parâmetros de interesse.

Ressalta-se que neste tópico são descritas linhas gerais do desenvolvimento dos trabalhos, sendo que os detalhes de aplicação do método e a fundamentação teórica são demonstrados nos itens relativos aos cálculos do volume de explotação e do consumo de energia elétrica, pois favorecem a demonstração dos resultados obtidos. 


\subsection{IDENTIFICAÇÃO DOS DADOS DISPONÍVEIS NO CADASTRO E A DETERMINAÇÃO DO RENDIMENTO DOS SISTEMAS DE BOMBEAMENTO}

O cadastro de poços do DAEE contava com dados completos dos parâmetros de interesse para um elenco de 273 poços, para os quais foram determinados os consumos de energia elétrica mensal, a partir dos dados de potencia de bomba e regime de operação de bombeamento.

O regime de operação do bombeamento foi determinado a partir dos dados medidos de vazão de explotação e das taxas de vazão de bombeamento disponíveis no cadastro.

Os dados de consumo de energia elétrica calculados, as vazões de explotação e os níveis dinâmicos informados no cadastro foram aplicados à equação do cálculo de potência hidráulica, obtendo-se os valores dos rendimentos dos sistemas de bombeamento instalados nos poços.

Considerando os valores médios de tarifa de energia elétrica aplicados pela concessionária (CPFL Paulista) para os diferentes perfis de usuário, foram calculados os custos de energia elétrica no bombeamento dos poços, por meio do produto do consumo determinado em kWh (quilowatt·hora) pela tarifa de energia.

Essa abordagem possibilitou a definição do padrão de consumo de energia elétrica e das taxas de eficiência de produção para os equipamentos em operação no elenco de 273 poços do cadastro com disponibilidade dos parâmetros de interesse.

O rendimento médio dos sistemas de bombeamento calculado a partir dos dados reais balizou a definição do rendimento teórico utilizado no cálculo do consumo de energia elétrica dos diferentes cenários de explotação do SAB simulados por modelação numérica. A avaliação de curvas características de bombas submersas também foi utilizada para a determinação do rendimento teórico dos sistemas de bombeamentos.

\subsection{DETERMINAÇÃO DA VAZÃO DE BOMBEAMENTO DOS POÇOS E O CÁLCULO DE EXPLOTAÇÃO DO SAB}

Os dados de vazão de explotação foram os mais precisos dentre todos os parâmetros de interesse, pois a maioria dos poços do cadastro contava com dados medidos de vazão. 
Desse modo, a determinação do dado estava diretamente disponível no cadastro para um grande elenco de poços.

As vazões medidas balizaram a determinação desse parâmetro para o grupo de poços que não disponibilizavam desses dados. Desse modo, todos os poços do cadastro contaram com dados de vazão de explotação, sendo possível determinar o volume total explotado do SAB.

No cadastro, os dados de vazão de explotação estavam apresentados em volume mensal, refletindo a periodicidade de leitura dos hidrômetros efetuada pelo Semae. A partir dos dados mensais de vazão e dos regimes de bombeamento arbitrados, foram determinadas as taxas de vazões de bombeamento em volume por hora, necessárias aos cálculos de consumo de energia elétrica no bombeamento.

O histórico de evolução do uso das águas subterrâneas do SAB, os dados sobre a finalidade de uso e o volume explotado permitiram a caracterização do modelo de explotação do SAB, a definição do padrão de consumo da sociedade riopretense e a estimativa da explotação atual.

\subsection{A DETERMINAÇÃO DO PARÂMETRO DE ALTURA MANOMÉTRICA}

O parâmetro de altura manométrica corresponde ao desnível a ser vencido pelo bombeamento, dado pela distância entre a posição do nível de água e a superfície do terreno, de acordo com a definição estabelecida nesta pesquisa.

A posição do nível de água, considerando que o poço está em bombeamento, é equivalente ao nível dinâmico. Entretanto, esse dado estava disponível a um pequeno elenco de poços. Além disso, o equilíbrio dinâmico do SAB é altamente perturbado por uma complexa interferência entre poços, principalmente na região central da cidade.

As considerações expostas acima levaram à determinação do nível de água e consequentemente do parâmetro de altura manométrica através de mapas potenciométricos modelados numericamente.

Os modelos numéricos que produziram os mapas potenciométricos foram desenvolvidos em estado estacionário e, desse modo, refletem a "fotografia" do equilíbrio dinâmico, resultante das entradas (recargas) e saídas (descargas e explotação) de água na região modelada. 
Foram utilizados mapas potenciométricos resultantes de simulações de diferentes cenários de explotação do SAB e definidos os limites geográficos da avaliação do consumo de energia elétrica como sendo a área de interseção dos modelos e, desse modo, comparando-se os efeitos dos diferentes cenários para o mesmo elenco de poços. A área de interseção dos modelos abrange integralmente o perímetro urbano de SJRP e pequenas partes circunvizinhas à franja urbana.

Os mapas potenciométricos dos modelos foram georreferenciados e interpolados com o modelo digital de elevação obtido a partir de imagem SRTM. A interpolação foi realizada com o uso do aplicativo ArcGIS, versão 10.0 e o resultado foi a geração de um mapa residual da diferença entre as cotas potenciométricas e as cotas topográficas, produzindo um mapa de profundidade do nível de água.

Nos mapas de profundidade do nível de água para cada cenário de explotação modelado foram plotados os poços existentes na área e, digitalmente, obtidos os dados de profundidade de nível de água para cada poço em cada cenário.

\subsection{DETERMINAÇÃO DO CONSUMO E DOS CUSTOS DE ENERGIA ELÉTRICA NO BOMBEAMENTO}

Os dados dos parâmetros de interesse para os cálculos do consumo de energia elétrica no bombeamento foram determinados conforme descrito anteriormente, permitindo-se obter, para cada um dos poços existentes na área de interseção dos modelos, o consumo de energia elétrica específico para cada cenário de explotação avaliado e os respectivos custos de energia.

Os consumos e os custos individuais de cada poço foram totalizados para todo o elenco de poços, em cada cenário simulado, e comparados os resultados obtidos. Os cenários de explotação eram distintos, porém para um mesmo elenco de poços e mesma área de abrangência.

A comparação entre os indicadores de consumo, eficiência e explotação de cada cenário possibilitou a avaliação da influência do modelo de explotação no custo de energia elétrica no bombeamento. 


\section{CONSUMO ENERGÉTICO NA EXPLOTAÇÃo DAS ÁGUAS SUBTERRÂNEAS}

Esta pesquisa possui como diferencial na caracterização do cenário de uso das águas subterrâneas do Sistema Aquífero Bauru em São José do Rio Preto, a avaliação do custo de energia elétrica na explotação das águas subterrâneas. Até o presente momento, nenhum dos trabalhos existentes discutiu sobre os aspectos econômicos relacionados aos efeitos causados pelo modelo de uso das águas subterrâneas na região.

Especificamente relacionado ao custo de energia elétrica na explotação de águas subterrâneas, também não foram encontrados muitos trabalhos desenvolvidos, bem como dados disponíveis sobre a medição do consumo de energia. Esse contexto motivou a necessidade de se estabelecer critérios para estimar os custos relacionados ao consumo de energia elétrica, baseados nos dados disponíveis.

Este tópico apresenta os fundamentos sobre a extração artificial de água de um aquífero com foco na caracterização dos parâmetros que influenciam o consumo de energia elétrica no bombeamento, o desenvolvimento na determinação dos valores dos parâmetros de interesse e os resultados dos cálculos do consumo de energia na explotação das águas subterrâneas do SAB em SJRP.

\subsection{FUNDAMENTOS DA EXPLOTAÇÃO DAS ÁGUAS SUBTERRÂNEAS E A INFLUÊNCIA NO CONSUMO DE ENERGIA}

O consumo de energia elétrica na captação das águas subterrâneas é necessário para a operação do bombeamento, responsável por vencer o desnível existente entre a posição da água subterrânea e a superfície, e, desse modo, alimentar as redes de distribuição e/ou os reservatórios.

Em condições naturais, um aquífero normalmente está em seu estado de equilíbrio dinâmico, no qual as descargas ocorrem em igual volume às recargas e, neste caso, a posição do nível da água reflete a potenciometria do aquífero em resposta ao gradiente hidráulico provocado pelas entradas (recargas) e saídas de água (descargas). 
A explotação feita a partir de um poço altera o estado de equilíbrio do aquífero, provocando a depleção das cargas hidráulicas em uma região no entorno do poço em bombeamento, gerando um cone de depressão ou cone de rebaixamento (FETTER, 2001), conforme ilustrado na Figura 5.1.

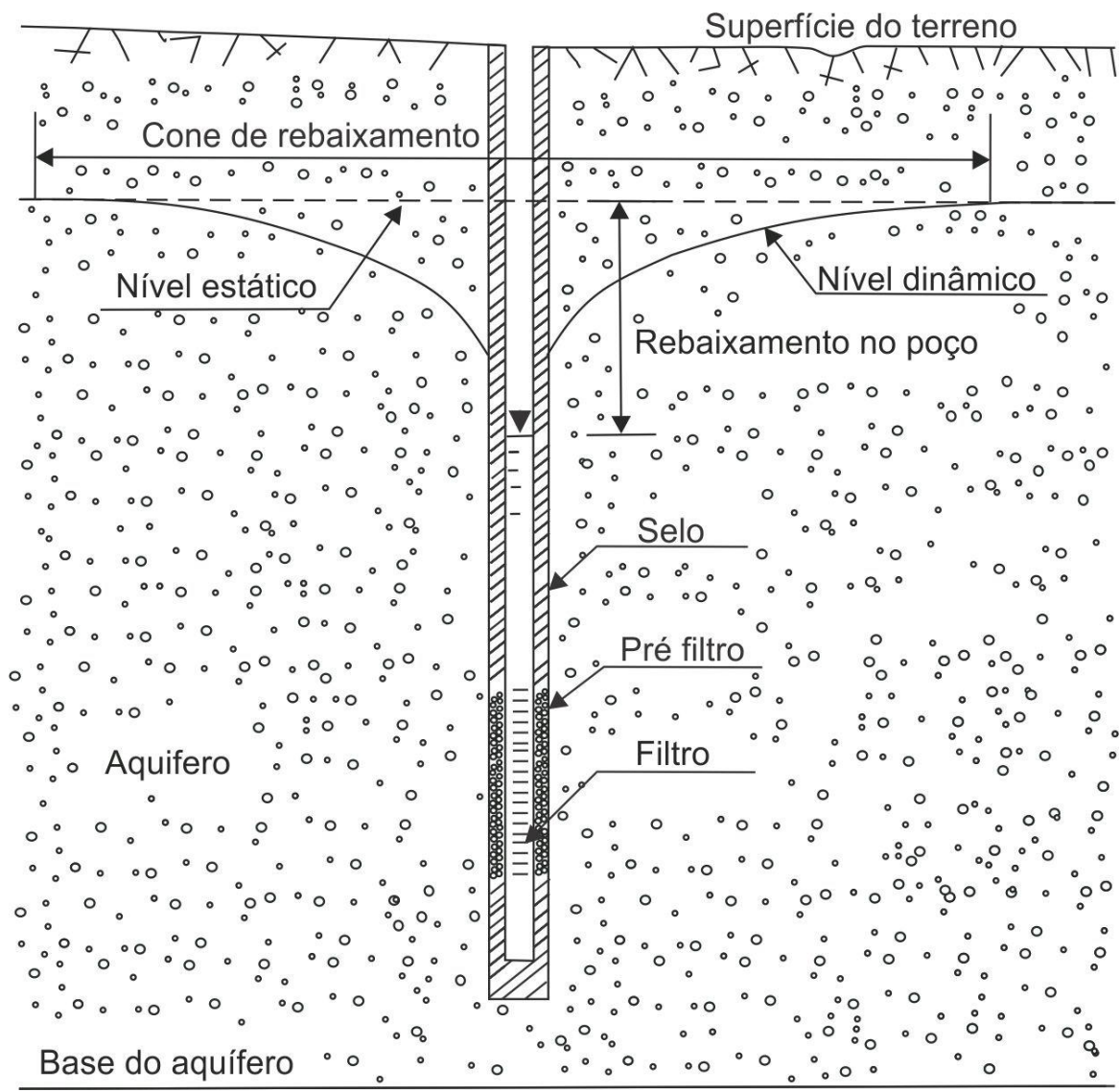

Figura 5.1 - Esquema de um poço em bombeamento com a demonstração do cone de rebaixamento e de elementos constituintes do poço (adaptado de CUSTODIO; LLAMAS, 2001)

O rebaixamento dos níveis potenciométricos durante o bombeamento em aquíferos livres, como é o caso do SAB, depende de fatores intrínsecos do aquífero (condutividade hidráulica, armazenamento, espessura saturada e porosidade específica), bem como, do tempo e da vazão do bombeamento (NEUMAN, 1972 apud FETTER, 2001).

${ }^{1}$ NEUMAN, S. P. 1972. Theory of flow in unconfined aquifers considering delayed response to the water table, Water Resources Research 8: 1031-45. 
O efeito do cone de rebaixamento ocorrendo em uma rede de poços em bombeamento pode intensificar a depleção dos níveis potenciométricos do aquífero, principalmente, se os poços estiverem densamente dispostos, onde o cone de um poço sobrepõe-se ao(s) cone(s) de rebaixamento(s) de outro(s) poço(s), conforme ilustrado na Figura 5.2. A situação na qual ocorre a sobreposição de cones de rebaixamento é denominada de interferência entre poços.

Em aquíferos confinados, que não há variação na espessura saturada, e em condições de equilíbrio, o fluxo da água subterrânea pode ser descrito pela equação de Laplace, que possui comportamento linear. Nessas condições, a interferência entre poços resulta na somatória dos cones de rebaixamento (FETTER, 2001), conforme mostra a Figura 5.2.

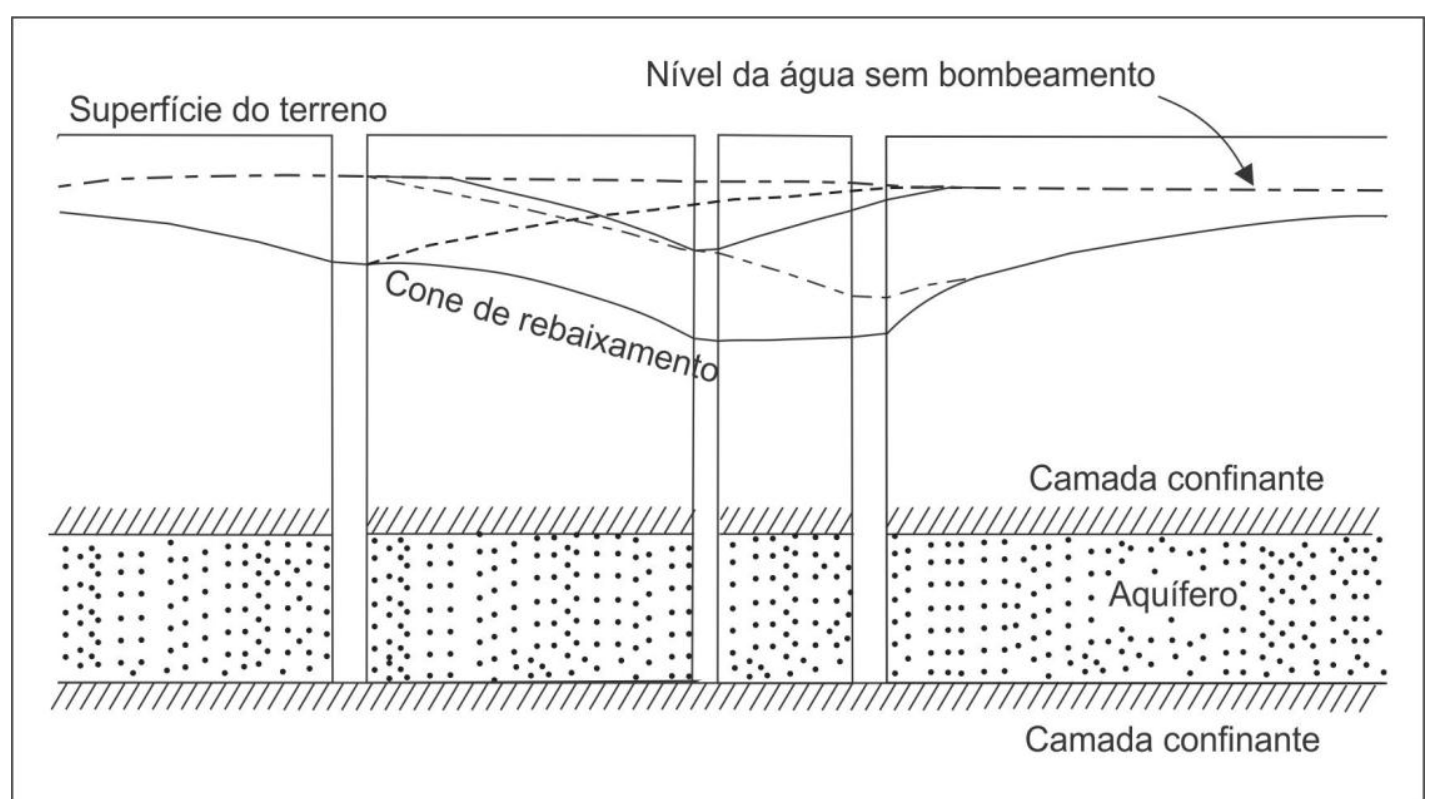

Figura 5.2 - Esquema de bombeamento de poços em interferência com a sobreposição de cones de rebaixamento (adaptado de FETTER, 2001)

Em aquíferos livres não ocorre o comportamento linear descrito anteriormente. A geração dos cones de rebaixamento ocasiona a diminuição da espessura saturada do aquífero e, consequentemente, da transmissividade. Nesse caso, a sobreposição dos cones de rebaixamento pode ser ainda maior que o provocado em aquíferos confinados, visando compensar a redução da transmissividade (FETTER, 2001).

$\mathrm{O}$ cone de rebaixamento provocado pelo bombeamento de um dado poço ou o rebaixamento resultante da interferência entre poços determinam a posição do nível de água em resposta à perturbação gerada pela extração de água. Essa posição do nível de água que pode ser medida no interior é denominada de nível dinâmico e corresponde à distância a ser transposta pela água até a superfície. 
O nível dinâmico é resultante da depleção do nível de água do aquífero e da soma dos rebaixamentos provocados pelas diversas causas de perdas de carga no poço (CUSTODIO; LLAMAS, 2001), conforme demonstrado na Figura 5.3.

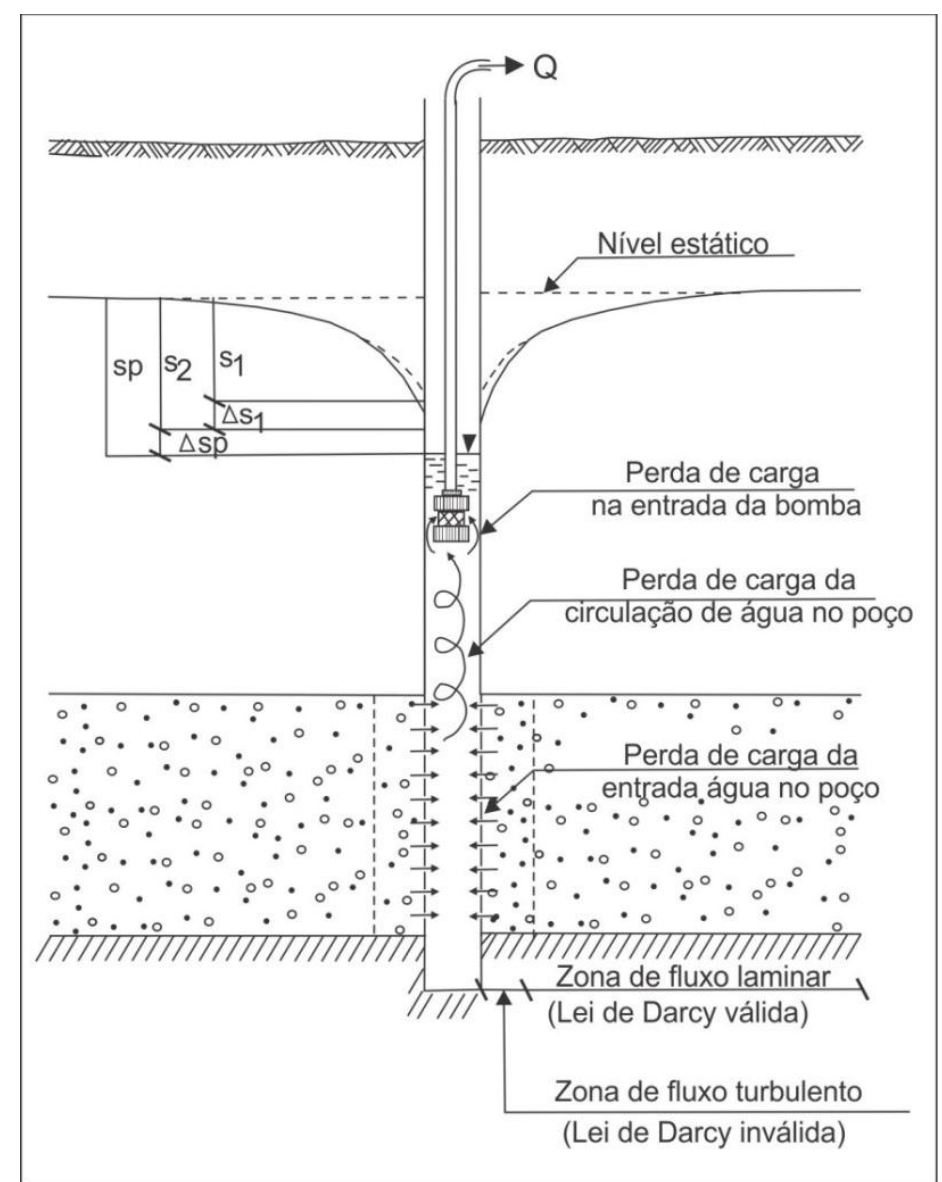

$\mathrm{s}_{\mathrm{p}}$ - rebaixamento no poço; $\mathrm{s}_{1}$ - rebaixamento originado pela explotação em regime de fluxo laminar;

$\mathrm{s}_{2}$ - rebaixamento real na parede externa do poço;

$\Delta \mathrm{s}_{1}$ - rebaixamento adicional originado por fluxos turbulentos na proximidade do poço;

$\Delta \mathbf{s}_{2}$ - rebaixamento adicional por perdas de cargas internamente ao poço.

Figura 5.3 - Ilustração esquemática de um poço em bombeamento com demonstração da formação do cone de rebaixamento e dos diversos efeitos que influenciam o rebaixamento do nível piezométrico (adaptado de CUSTODIO; LLAMAS, 2001)

As perdas de carga do poço ocorrem influenciadas por características naturais do aquífero e por aspectos construtivos do poço, em função da vazão de explotação empregada. Algumas causas que podem provocar perdas de carga no poço e influenciar a eficiência do bombeamento são: diâmetro do poço em relação à vazão de explotação; geração de fluxos turbulentos nas proximidades do poço, na entrada dos filtros e/ou no interior do mesmo; posicionamento da bomba em relação aos filtros; diâmetro da bomba em relação ao diâmetro do poço, entre outras. Rorabaugh ${ }^{1}$ (1953 apud CUSTODIO; LLAMAS, 2001) definiu a equação geral (equação 5.1) que descreve o rebaixamento de um poço.

${ }^{1}$ RORABAUGH. M.I. Graphycal and theoretical analysis of step drawdown test of artesian well. Proc. Am. Soc. Civil Eng. Vol. 79 dic. 1953. 


$$
\mathrm{S}_{\mathrm{p}}=\mathrm{B} \cdot \mathrm{Q}+\mathrm{C} \cdot \mathrm{Q}^{\mathrm{n}}
$$

Onde:

$\mathrm{S}_{\mathrm{p}}$ é o rebaixamento no poço;

B é o coeficiente de perdas de circulação na formação;

C é o coeficiente de perdas no poço;

Q é a vazão de explotação; e

n é um valor que pode variar de 1 a 3, tendo sido fixado em 2 por Jacob (1947 apud CUSTODIO; LLAMAS, 2001).

A partir da equação 5.1 pode-se avaliar que, se $n>1$, então as perdas de carga no poço são mais representativas que as perdas oriundas da circulação na formação e, ainda, que aumentam exponencialmente com o aumento da explotação.

A eficiência do bombeamento influenciada pelas perdas de carga pode ser demonstrada a partir de curvas características de poços, conforme ilustrado na Figura 5.4 que traz o comportamento padrão de curvas de poço para algumas condições gerais.

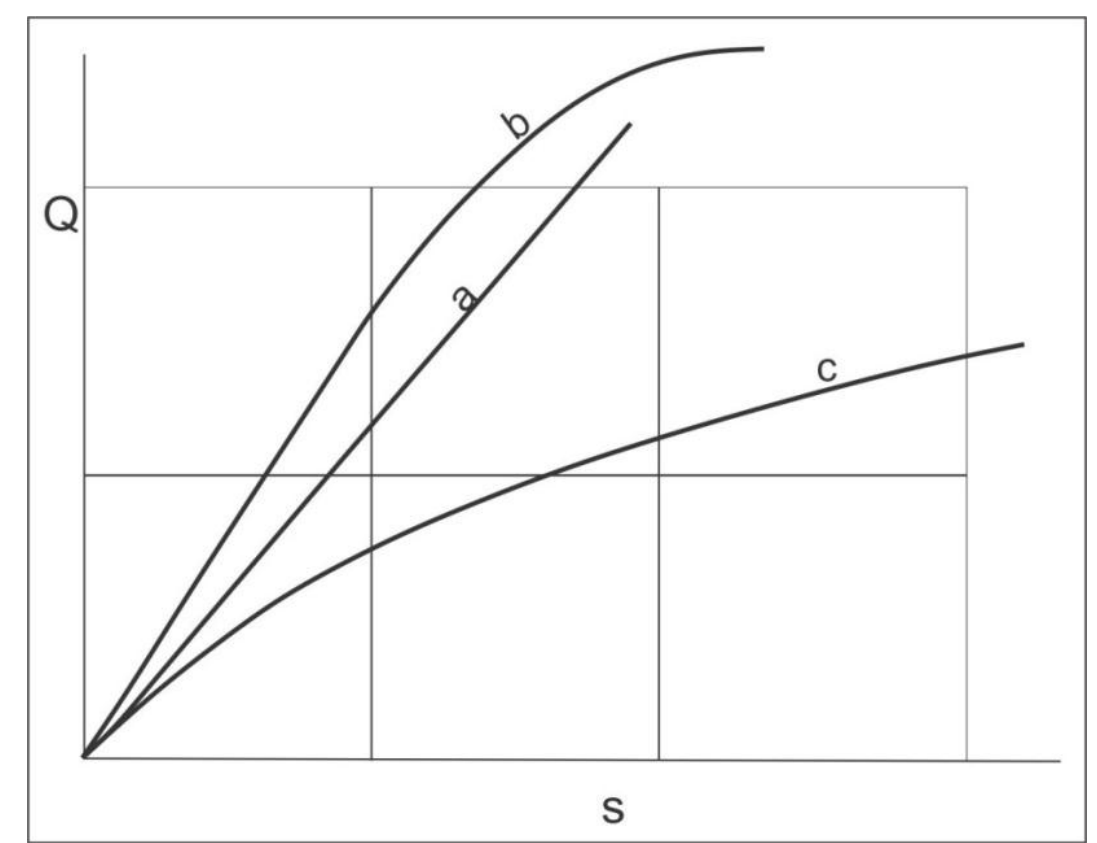

Figura 5.4 - Tipos de curvas características de poço mostradas no gráfico "Q (vazão) / s (rebaixamento no poço)": a) em aquífero confinado sem a perda de carga no poço; b) em aquífero livre sem a perda no poço; c) comportamento com perdas de carga no poço (adaptado de CUSTODIO; LLAMAS, 2001)

$\overline{{ }^{1} J A C O B}$, C. E. Drawdown test to determine effective radius of artesian well. Trans. Am. Soc. Civil Eng. Vol 72. Artículo 2321, 1947, pag. 1047. 
Em situações reais, é comum que a eficiência do poço não alcance patamar de 100\%, determinando, desse modo, uma diminuição da vazão de explotação ou um maior rebaixamento do nível dinâmico ou uma combinação desses dois efeitos, resultando em um poço com curva característica do tipo "c" (Figura 5.4).

A eficiência do poço e os parâmetros de operação, tais como a vazão de explotação, o regime de funcionamento (quantidade de horas de bombeamento por dia) e o nível dinâmico são definidos em ensaios de bombeamento realizados após a construção, limpeza e desenvolvimento do poço. Esses ensaios também permitem calcular alguns parâmetros hidráulicos do aquífero. A partir da determinação da eficiência do poço e dos parâmetros operacionais pode-se definir o equipamento de bombeamento do poço.

A extração das águas subterrâneas em poços ocorre por meio de bombas de inúmeros tipos e modelos, entretanto, a partir do advento e da produção em larga escala das bombas submersas, essas se tronaram o tipo de equipamento mais utilizado no bombeamento das águas subterrâneas em poços tubulares. Por essa razão, este estudo efetuou as avaliações de custo da explotação das águas subterrâneas considerando os padrões de consumo energético de bombas submersas, conforme será detalhado a seguir.

Deve-se estabelecer, para efeito de denominação do equipamento submerso de captação das águas subterrâneas, que o termo bomba é utilizado amplamente para designar o conjunto bombeador que é dotado da bomba, propriamente dita, e do motor da bomba.

Os principais parâmetros que influenciam a escolha e, sobretudo, a potência do conjunto bombeador (bomba) são: a altura manométrica $(H)$, que corresponde à diferença de altitude entre o nível dinâmico e o ponto de destino das águas; e a vazão de explotação $(\mathrm{Q})$, em volume desejável ou possível de ser retirado a partir do poço.

A potência da bomba é o parâmetro que determina o consumo de energia, em geral, definida nas especificações das bombas submersas em cavalo vapor $(1 \mathrm{CV}=0,736 \mathrm{~kW})$ ou cavalo-de-força $(1 \mathrm{hp}=0,745 \mathrm{~kW})$. As equações que calculam a potência do conjunto bombeador são (CUSTODIO; LLAMAS, 2001):

$$
P_{t}(\mathrm{kgm} / \mathrm{s})=\frac{Q\left(\mathrm{~m}^{3} / \mathrm{s}\right) \cdot H(\mathrm{~m})}{\rho_{b}} \quad \text { ou } \quad P_{t}(\mathrm{CV})=\frac{Q\left(\mathrm{~m}^{3} / \mathrm{s}\right) \cdot H(\mathrm{~m})}{75 \cdot \rho_{b}}
$$

Onde:

$\mathrm{P}_{\mathrm{t}}$ é a potencia teórica do motor;

Q é a vazão de bombeamento;

H é a altura manométrica;

$\rho_{\mathrm{b}}$ é o rendimento da bomba. 
$\mathrm{Na}$ equação 5.2 acima, a potência determinada é chamada de teórica, pois não considera as perdas relacionadas ao motor. O rendimento do motor $\left(\rho_{\mathrm{m}}\right)$, geralmente, está em torno de 90\% (CUSTODIO; LLAMAS, 2001). Desse modo, a potência nominal do conjunto bombeador que será consumida da rede elétrica (Potência consumida $-\mathrm{P}_{\mathrm{c}}$ ) será maior que a teórica do motor. Neste caso, o cálculo da potência é descrito conforme a equação 5.3 abaixo, já expressa em quilowatt $(\mathrm{kW})$, conforme unidade de medição do consumo de energia elétrica utilizado pelas prestadoras de serviço.

$$
P_{c}(k W)=\frac{P_{t}}{\rho_{m}} \times 0,736=\frac{Q\left(m^{3} / s\right) \cdot H(m) \cdot 0,736}{75 \cdot \rho_{b} \cdot \rho_{m}}
$$

A seleção do modelo da bomba e, eventualmente, de sua potência também pode ser influenciada pelo diâmetro do poço e pela tensão de alimentação da rede elétrica.

A Figura 5.5 apresenta o comportamento padrão de curva característica de bomba submersa, demonstrando que para uma dada bomba, de uma dada potência, a vazão e a altura manométrica possuem dimensões inversas, ou seja, o aumento na altura manométrica provoca a diminuição da vazão explotada e vice-versa.

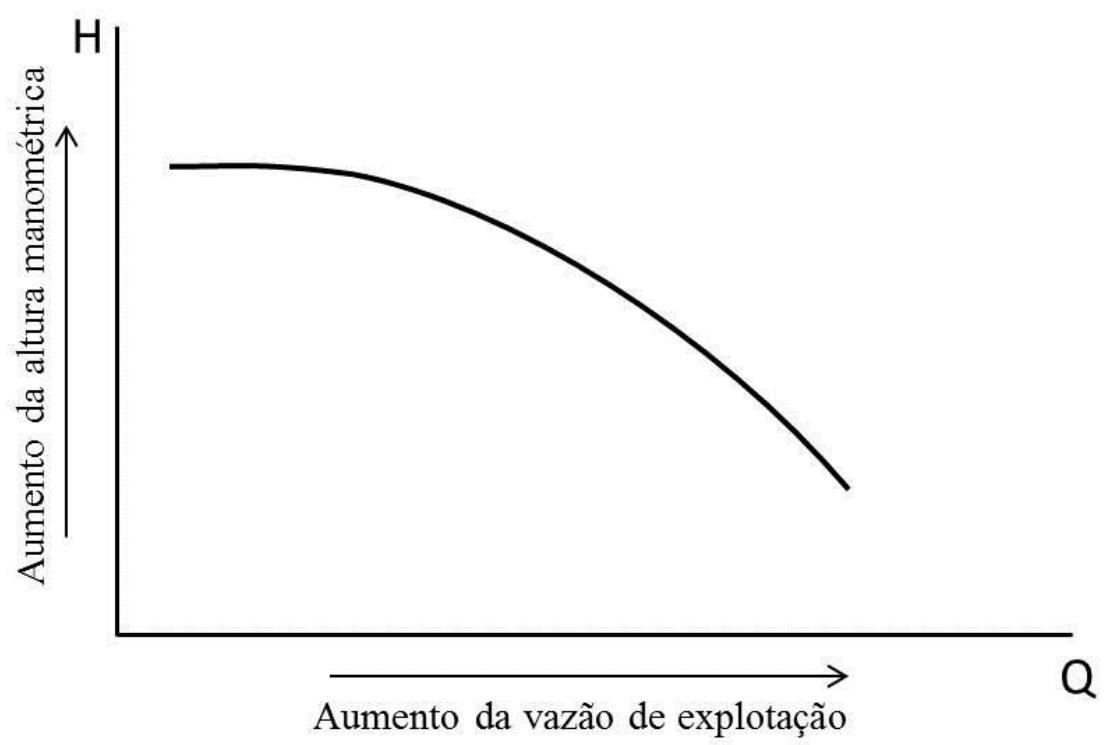

Figura 5.5 - Curva característica de bomba submersa

Em análise às curvas características de conjuntos bombeadores submersos de fabricantes brasileiros, verificou-se que os rendimentos demonstrados nos catálogos dos produtos variavam de $50 \%$ a $75 \%$ com a aplicação da equação 5.3 . 
A extração das águas subterrâneas, devido à profundidade de captação, é ativada pela bomba, porém direcionada à superfície por tubulação Este conjunto hidráulico "bomba / tubo edutor" também pode ser denominado de sistema de bombeamento.

A tubulação edutora no interior do poço é dotada de canos e luvas ou somente canos com conexões "macho e fêmea", constituindo um componente retilíneo, da bomba até a saída do poço, na superfície. Externamente ao poço, podem existir curvas, válvulas, medidores (hidrômetros), conexões (niples, uniões), etc. Em todo esse conjunto edutor podem ocorrer perdas de carga devido ao material da tubulação, rugosidades internas dos tubos, incrustações, estrangulamentos, turbulências geradas por mudança de direção do fluxo (curvas), entre outros motivos.

As perdas de cargas na tubulação edutora podem ser estimadas através da equação 5.4, a fórmula fundamental da perda de carga em regime turbulento (CUSTODIO; LLAMAS, 2001; RECESA, 2008), que transforma estes efeitos de resistência ao fluxo, diminuição de velocidade e outros comportamentos físicos, em unidades equivalentes à altura manométrica, ou seja, adicionam metragem irreal a ser vencida pela potencia do equipamento de bombeamento.

$$
h_{f}=f \frac{L}{D} \frac{v^{2}}{2 g}
$$

Onde:

$h_{f}=$ perda de carga distribuída $(\mathrm{m})$;

$f=$ coeficiente de atrito, função do número de Reynolds e da rugosidade relativa;

$L=$ comprimento da tubulação (m);

$D=$ diâmetro da tubulação (m).

$v=$ velocidade média, $\mathrm{m} / \mathrm{s}$;

$g=$ aceleração da gravidade, $\mathrm{m} / \mathrm{s} 2$;

Considerando os fatores integrados de todo o sistema de bombeamento, as curvas características da bomba e da tubulação edutora podem ser expressas conforme demonstrado na Figura 5.6, na qual se observa que o ponto $\mathrm{M}$, na intersecção das curvas da bomba e da tubulação, representa o ponto de funcionamento da bomba com o maior índice de rendimento do sistema. 


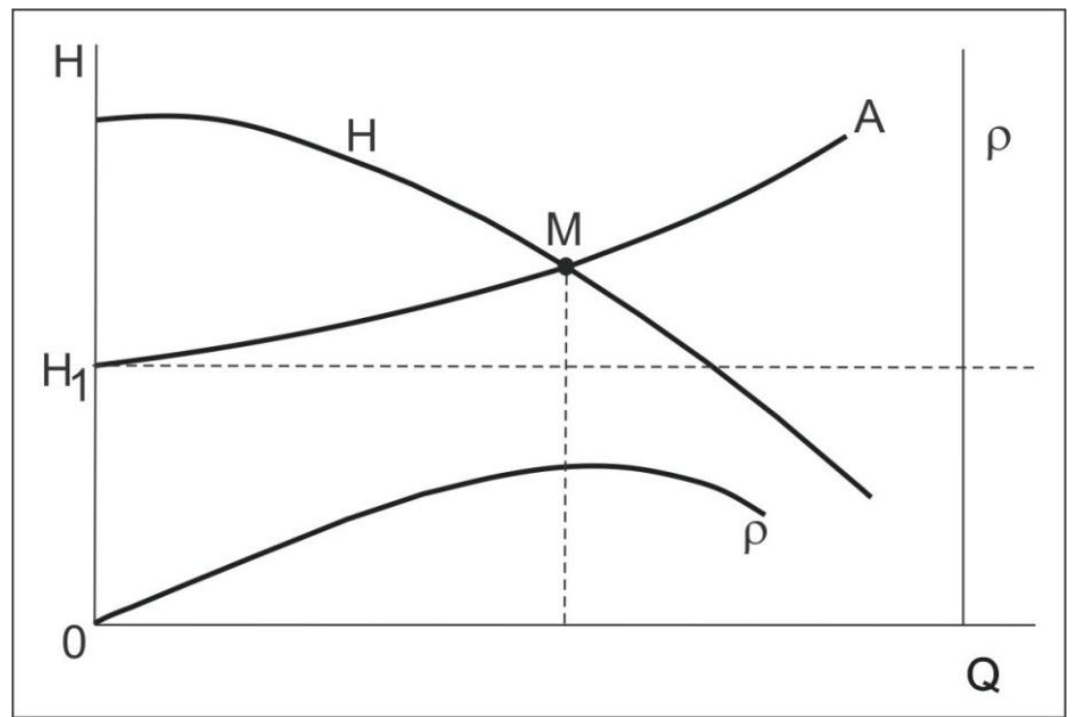

Figura 5.6 - Gráfico de "Q (vazão) / H (altura manométrica)" contendo as curvas características da bomba $(\mathrm{H})$ e da tubulação edutora $\left(\mathrm{H}_{1} \mathrm{~A}\right)$, a indicação do ponto de melhor eficiência do sistema de bombeamento (M) e a curva de eficiência do sistema $(\rho)$

Nas condições de bombeamento da água subterrâneas discutidas anteriormente, o consumo de energia pode ser calculado a partir da seguinte equação:

$$
E=0,00273 \frac{H Q}{\rho_{s}}
$$

Onde:

$E$ é a energia consumida $(\mathrm{kWh})$;

$H$ é a altura manométrica de bombeamento (m);

$Q$ é o volume de água bombeada ou vazão de explotação $\left(\mathrm{m}^{3} / \mathrm{h}\right)$;

$\rho_{s}$ é o rendimento do sistema de bombeamento.

A equação 5.5 corresponde à aplicação da equação da potência hidráulica (equação 5.6), adotando-se a constante 0,00273 como fator de correção das unidades para se determinar o consumo em quilowatt hora $(\mathrm{kWh})$, incluindo o valor da aceleração da gravidade. Para ilustrar, considerando-se um rendimento de $100 \%$, o consumo de energia necessário para elevar um metro cúbico de água, por uma hora, a altura de um metro é de $0,00273 \mathrm{kWh}$. 
A equação da potência hidráulica é descrita como:

$$
P_{h}=\rho \times g \times H \times Q
$$

Onde:

$\mathrm{P}_{\mathrm{h}}$ é o potencial hidráulico (W ou, no sistema métrico, $\mathrm{kg} \cdot \mathrm{m}^{2} / \mathrm{s}^{3}$ );

$\rho$ é a massa específica da água $\left(\mathrm{kg} / \mathrm{m}^{3}\right)$;

$g$ é a aceleração da gravidade $\left(\mathrm{m} / \mathrm{s}^{2}\right)$;

H é a altura manométrica (m); e

Q é a vazão $\left(\mathrm{m}^{3} / \mathrm{s}\right)$.

Pelo que se observa na equação 5.5, para diminuir os custos de energia é necessário reduzir a altura manométrica ou o volume da água bombeada, ou aumentar a eficiência dos sistemas de bombeamento (RECESA, 2008), sendo que neste último item, incluem-se padrões construtivos dos poços, seleção da bomba e especificações de tubulações.

Adicionalmente à discussão efetuada anteriormente, destaca-se que, sem a adoção de equipamentos controladores do consumo de energia como, por exemplo, os inversores de frequência, a potência nominal da bomba será utilizada integralmente, independentemente do nível de rendimento, altura manométrica e vazão, ocorrendo invariavelmente desperdícios de energia elétrica, elevando-se o consumo específico de $\mathrm{kWh} / \mathrm{m}^{3}$, conforme demonstrado em estudos anteriores (TSUTIYA, 2001; PERRONI, 2005) que analisaram o consumo de energia elétrica de conjuntos de bombeamento.

No caso de captação de águas subterrâneas ainda há um fator agravante que reforça a utilização de inversores de frequência, pois os poços, na maioria dos casos, não operam ininterruptamente, sendo exigido um consumo extra de energia para cada partida, conforme demonstrado por Perroni (2005) e ilustrado na Figura 5.7.

Os gráficos da Figura 5.7 mostram a variação da corrente elétrica (I) que influencia na variação da potência do equipamento e, consequentemente, no consumo de energia, conforme descrito pela equação 5.7, abaixo:

$$
P_{o}=\sqrt{3} \cdot I \cdot V \cdot \cos \varphi
$$

Onde:

$\mathrm{P}_{\mathrm{o}}$ é a potência de operação;

I é a corrente elétrica;

$\mathrm{V}$ é a voltagem da rede elétrica;

$\cos \varphi$ é o fator de potência. 

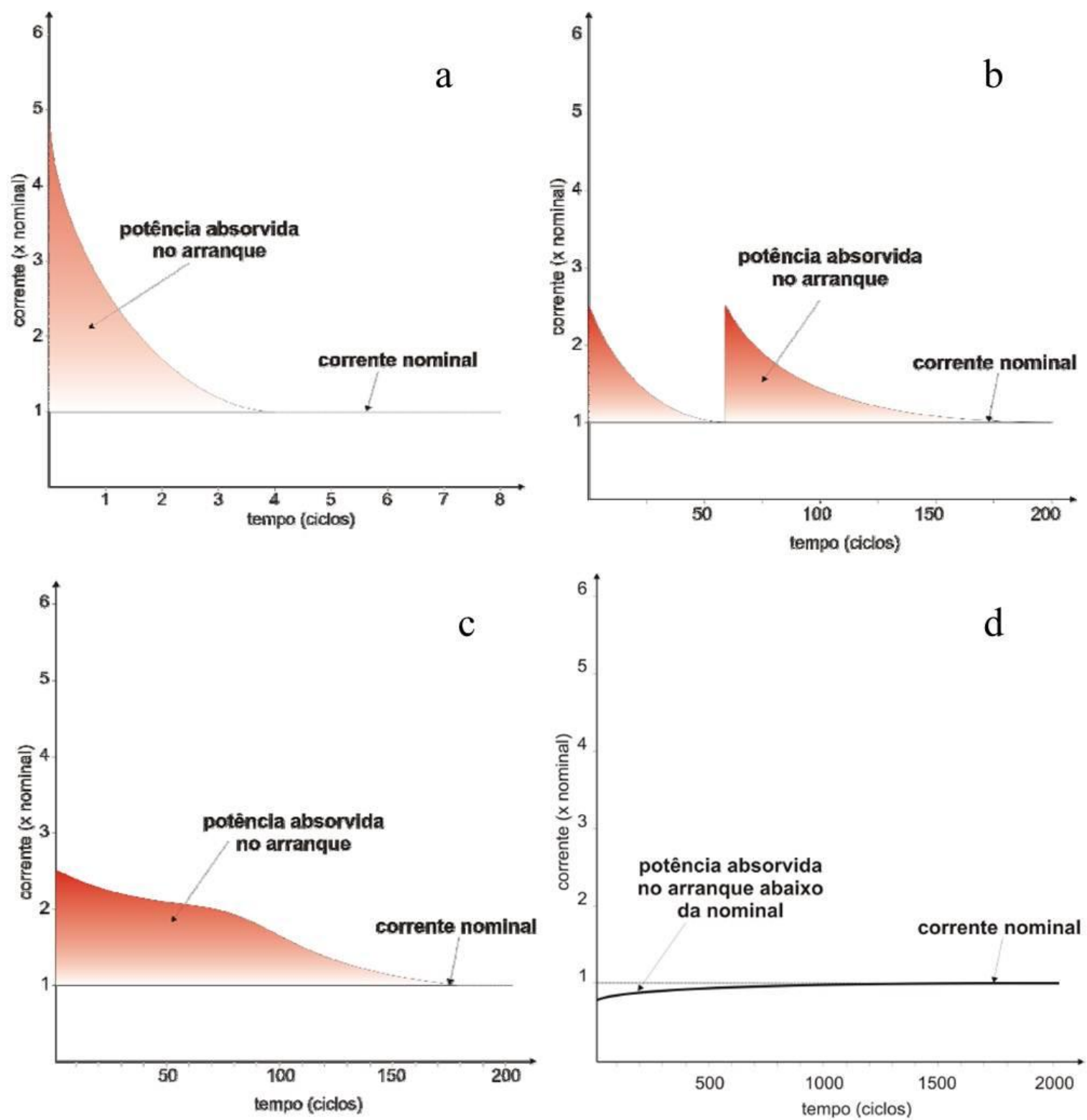

Figura 5.7- Gráficos esquemáticos da potência consumida durante o arranque de motor elétrico: a) com partida direta; b) com autotransformador; c) com partida suave; d) com inversor de frequência (adaptado de Perroni, 2005)

A equação 5.7 também é utilizada na seleção dos cabos elétricos do sistema de bombeamento, já que permite determinar qual é a corrente elétrica da operação do sistema.

A discussão apresentada neste tópico acerca dos fatores que podem influenciar no consumo de energia elétrica para a explotação de águas subterrâneas objetivou a demonstração das inúmeras variáveis que devem ser consideradas nos casos de avaliação e gestão do consumo e na redução de perdas de energia elétrica. Nesses casos, as ações de avaliação e otimização do consumo de energia na explotação de águas subterrâneas devem ser 
conduzidas individualmente para cada poço e para cada sistema de bombeamento, buscando a melhor eficiência energética em cada componente do sistema (bomba, motor e tubulação).

A eficiência energética poderá ser melhorada também pela adequada definição da rede elétrica (voltagem e corrente de operação), bem como pela gestão operacional, ligando o sistema em períodos de menores tarifas de energia elétrica (TSUTIYA, 2001; TSUTIYA; DAVID, 2005; RECESA, 2008).

Conforme será apresentado no item a seguir, este trabalho visa a uma avaliação do consumo de energia na explotação, de maneira ampla para todo o município SJRP, devido ao cenário de depleção dos níveis potenciométricos. As avaliações individuais de eficiência energética dos sistemas de bombeamento não serão conduzidas, não somente pelos objetivos gerais desta pesquisa, mas também pela indisponibilidade de informações dos parâmetros de interesse necessários.

Deve-se ressaltar, entretanto, que seria de grande valia uma avaliação detalhada do padrão de consumo energético individual, com foco na obtenção de indicadores, planos e metas de melhorias da sustentabilidade da explotação das águas subterrâneas. Uma avaliação nesses moldes poderia ser bastante útil, favorável ambientalmente e financeiramente salutar, sobretudo, à concessionária de abastecimento público, no caso o Semae, e à sociedade riopretense.

\subsection{ANÁLISE DO CONSUMO DE ENERGIA ELÉTRICA EM POÇOS DO CADASTRO E A AVALIAÇÃO DO RENDIMENTO NA EXPLOTAÇÃO}

O cenário ideal para um trabalho de avaliação de possíveis incrementos no custo de energia da explotação da água subterrânea, decorrentes do modelo de uso intenso existente em SJRP, seria que em cada poço houvesse um medidor de consumo de energia elétrica (padrão de energia) exclusivo para a operação do sistema de bombeamento, instalado desde a construção do poço. Pois bem, esse cenário ideal está muito distante de existir.

Os poços privados, cerca de $90 \%$ dos poços existentes, raramente possuem um padrão de energia exclusivo, pois sua alimentação elétrica é dada pela rede da própria residência, condomínio ou empreendimento onde está instalado. Desse modo, o consumo de energia elétrica relativo ao funcionamento do poço é medido juntamente com todos os demais consumos existentes no local. 
Os poços de abastecimento público tem uma realidade um pouco diferente. Esses poços estão instalados geralmente em áreas públicas (praças, canteiros de avenidas, lotes vazios, etc) e, desse modo, não contam com uma rede elétrica já instalada, necessitando de um padrão de energia praticamente exclusivo para o poço. Em alguns casos, pode ser que o padrão de energia também inclua outra bomba de recalque, luzes e, eventualmente, mais de um poço (PERRONI; WENDLAND, 2006). De qualquer maneira, é provável que o Semae conte com poços, nos quais, seja possível avaliar com bastante precisão o consumo de energia. Lamentavelmente, dados dessa natureza não foram disponibilizados pelo Semae, pois poderiam balizar as estimativas de consumo de energia efetuadas neste trabalho.

Essas limitações relativas aos dados de consumo de energia dos sistemas de bombeamento nos poços motivaram a necessidade de estimar o consumo a partir de outros critérios, utilizando os dados disponíveis no cadastro.

No cadastro de poços do DAEE (2008), foram selecionados 273 poços, localizados internamente à área de interseção dos modelos numéricos (Figura 3.23) que dispõem de informações consistentes sobre o modelo de bomba, potência nominal da bomba e nível dinâmico, além do dado de volume explotado que está disponível para todos os poços (medido ou estimado), visando estimar o consumo de energia e obter a eficiência média para esse elenco de poços e permitir a comparação com os resultados obtidos nos cenários modelados.

Os poços selecionados abrangem todas as finalidades de uso, sendo 129 poços de abastecimento público, 74 domésticos, 33 industriais, 31 comerciais e 6 de outras finalidades de uso, configurando um elenco representativo de todo o universo de poços do cadastro. Ressalta-se que os poços de abastecimento público estão representados em maior número, pois, no cadastro, são os que possuem maior disponibilidade de informações completas e seguras sobre os parâmetros de interesse.

O consumo de energia foi obtido a partir dos dados de potência nominal das bombas, atribuindo-se um regime de bombeamento em horas por dia. A partir da avaliação realizada neste trabalho sobre os volumes explotados pelos poços, foram determinados dois padrões de regime operacional, sendo de $15 \mathrm{~h} /$ dia para os poços de abastecimento público e de $3 \mathrm{~h} / \mathrm{dia}$ para os poços com demais tipos de uso. 
Considerando os regimes de bombeamento indicados anteriormente, o consumo de energia foi estimado pela equação 5.8 a seguir:

$$
C=P_{n} \times R
$$

Onde:

C é o consumo $(\mathrm{kWh} / \mathrm{dia})$;

$\mathrm{P}_{\mathrm{n}}$ é a potência nominal da bomba $(\mathrm{kW})$;

$\mathrm{R}$ é o regime operacional (h/dia).

A aplicação da equação 5.8 permitiu o cálculo do consumo diário e, com este, foi obtido o consumo mensal para compatibilizar com o período de medição das vazões de explotação.

Adotando-se tarifas de energia elétrica aplicadas pela concessionária que opera na região de SJRP, foi possível estimar os custos mensais relativos aos consumos de energia calculados. Foram adotados os valores de $\mathrm{R} \$ 0,33$ para o uso doméstico, de $\mathrm{R} \$ 0,22$ para o abastecimento público e de $\mathrm{R} \$ 0,21$ para os usos industriais, comerciais e outros (CPFL PAULISTA, 2012). Essas tarifas representam valores médios para diferentes modalidades de cobrança para diferentes perfis de usuários, conforme informações disponibilizadas na página da CPFL PAULISTA na internet.

A Tabela 5.1 traz a compilação dos valores dos parâmetros de interesse, das estimativas do consumo de energia e os custos associados, obtidos a partir da abordagem descrita anteriormente, apresentados separadamente pelos tipos de uso e para todo o elenco dos 273 poços. As Figuras 5.8 e 5.9 comparam, nos diferentes usos das águas subterrâneas, o consumo e o custo de energia elétrica, bem como das taxas de produtividade, com base nos valores demonstrados na Tabela 5.1.

O abastecimento público representa $86 \%$ da vazão de explotação, $91 \%$ do consumo de energia e $88 \%$ do custo de energia elétrica dos totais calculados avaliado, conforme demonstrado na Figura 5.8 que ilustra os percentuais de participação dos diferentes usos na captação, consumo e custo energético calculados para os 273 poços selecionados. 
Tabela 5.1 - Valores dos parâmetros de interesse e do consumo de energia elétrica obtidos com base nos dados do cadastro de poços

\begin{tabular}{|c|c|c|c|c|c|c|c|}
\hline Parâmetros & Unidade & Abast. Público & Doméstico & Industrial & Comercial & Outros & $\begin{array}{c}\text { Todos os } \\
\text { usos }\end{array}$ \\
\hline $\mathrm{n}$ & un & 129 & 74 & 33 & 31 & 6 & 273 \\
\hline $\mathrm{H}^{*} \mathrm{mx}$ & $\mathrm{m}$ & 134,98 & 117,00 & 116,20 & 80,56 & 76,94 & 134,98 \\
\hline $\mathrm{H}^{*} \mathrm{md}$ & $\mathrm{m}$ & 85,89 & 55,10 & 53,15 & 45,41 & 49,83 & 68,20 \\
\hline Q md & $\mathrm{m}^{3} / \mathrm{h}$ & 18,65 & 16,56 & 10,01 & 10,11 & 9,09 & 15,86 \\
\hline$P_{n} m d$ & $\mathrm{~kW}$ & 10,9 & 5,8 & 5,2 & 3,6 & 2,9 & 7,8 \\
\hline$P_{n}$ total & $\mathrm{kW}$ & 1.409 & 430 & 170 & 112 & 17 & 2.138 \\
\hline Q mn & $\mathrm{m}^{3} / \mathrm{mês}$ & 1.097 .802 & 111.792 & 30.145 & 28.598 & 4.978 & 1.273 .315 \\
\hline CE mn & $\mathrm{kWh} / \mathrm{mês}$ & 642.628 & 39.249 & 15.535 & 10.231 & 1.574 & 709.217 \\
\hline $\mathrm{C} \mathrm{mn}$ & $\mathrm{R} \$ / \mathrm{mês}$ & $141.378,19$ & $12.952,14$ & $3.262,42$ & $2.148,60$ & 330,55 & $160.071,90$ \\
\hline TP1 & $\mathrm{kWh} / \mathrm{m}^{3}$ & 0,59 & 0,35 & 0,52 & 0,36 & 0,32 & 0,56 \\
\hline TP2 & $\mathrm{R} \$ / \mathrm{m}^{3}$ & 0,13 & 0,12 & 0,11 & 0,08 & 0,07 & 0,13 \\
\hline TP3 & $\mathrm{m}^{3} / \mathrm{R} \$$ & 7,77 & 8,63 & 9,24 & 13,31 & 15,06 & 7,95 \\
\hline
\end{tabular}

*o parâmetro de altura manométrica $(\mathrm{H})$ corresponde ao dado de profundidade do nível dinâmico disponível no cadastro de poços.

n: quantidade de poços considerada nos cálculos;

H mx: altura manométrica máxima;

H md: altura manométrica média;

Q md: vazão de explotação média;

$\mathrm{P}_{\mathrm{n}}$ md: potência nominal média dos equipamentos instalados nos poços avaliados;

$\mathrm{P}_{\mathrm{n}}$ total: potência nominal total, correspondente à somatória das potências dos equipamentos instalados nos poços avaliados;

Q mn: vazão de explotação total mensal;

CE mn: consumo de energia elétrica total mensal;

C mn: custo mensal de energia elétrica;

TP1: taxa de produtividade correspondendo à relação consumo energético por volume produzido;

TP2: taxa de produtividade correspondendo à relação do custo com energia elétrica por volume produzido;

TP3: taxa de produtividade correspondendo à relação de volume produzido por custo unitário, ou seja, quantos metros cúbico podem ser produzidos com $\mathrm{R} \$ 1,00$. 


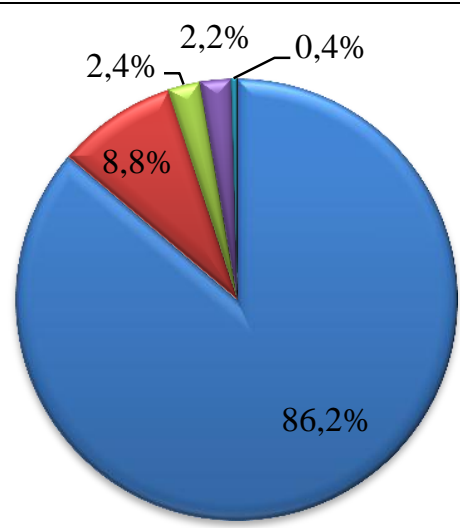

Vazão de Explotação Total $-1.273 .315 \mathrm{~m}^{3} / \mathrm{mês}$

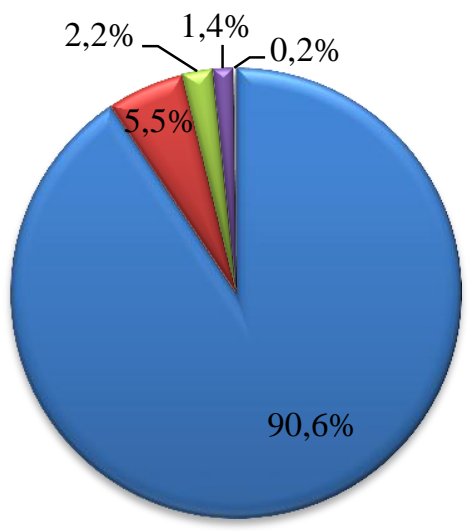

Consumo de energia elétrica Total - 709.217 kWh/mês

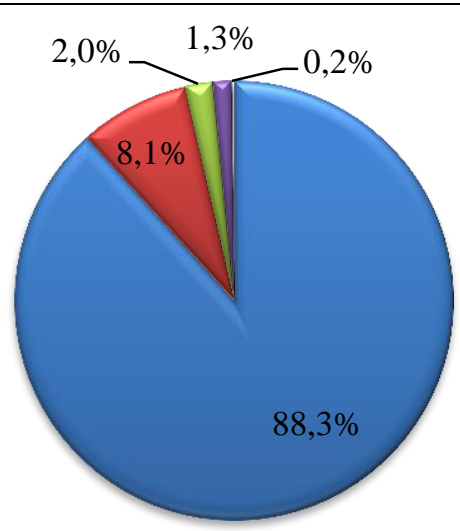

Custo de energia elétrica Total - R\$ 141.378,19 / mês

Total de poços analisados - 273

Figura 5.8 - Gráficos de vazão de explotação, consumo e custo de energia elétrica, demonstrando os percentuais de participação para os tipos de uso, calculados em 273 poços do cadastro.
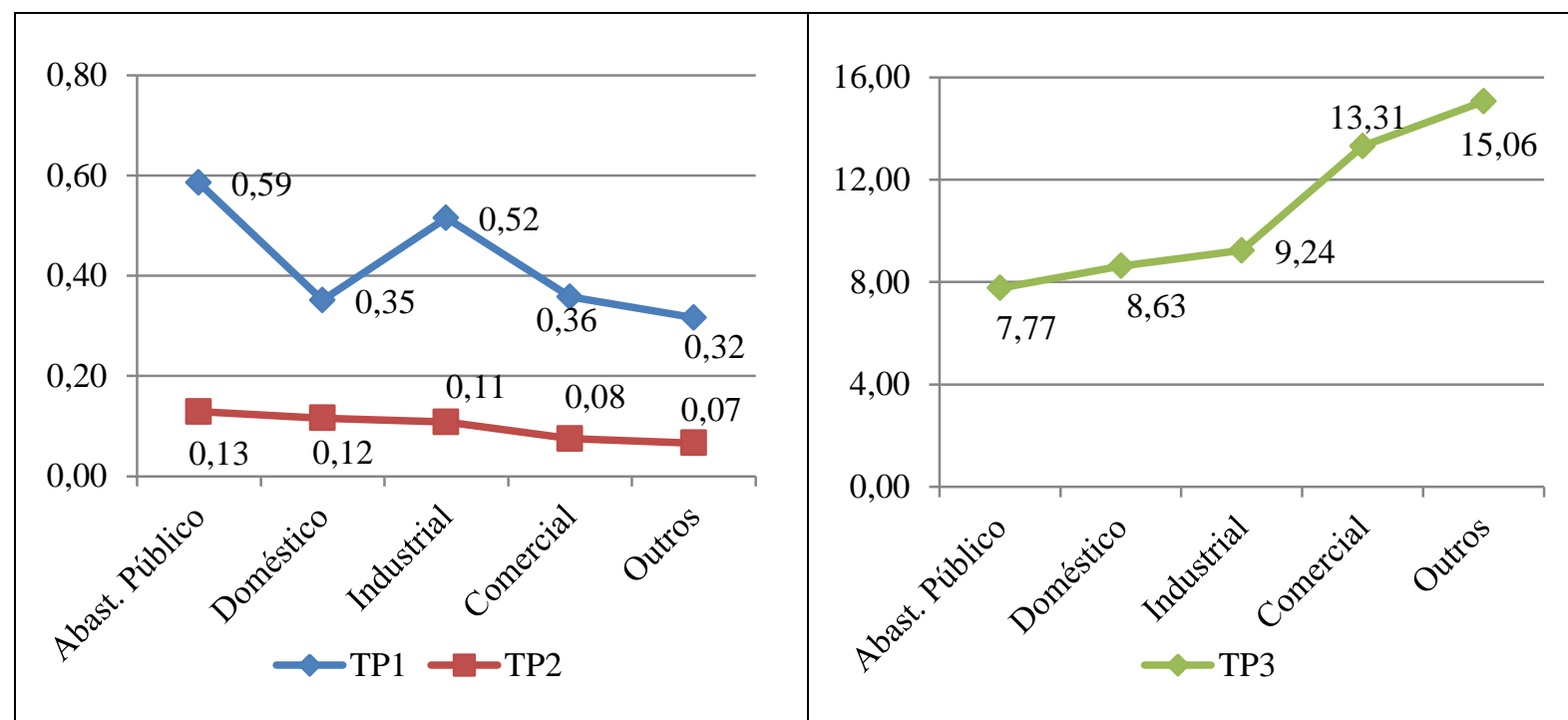

TP1: taxa de produtividade da relação "consumo energético/volume produzido" $\left(\mathrm{kWh} / \mathrm{m}^{3}\right)$

TP2: taxa de produtividade da relação "custo de energia elétrica/volume produzido" $\left(\mathrm{R} \$ / \mathrm{m}^{3}\right)$

TP3: taxa de produtividade da relação "volume produzido/custo de energia elétrica" $\left(\mathrm{m}^{3} / \mathrm{R} \$ 1,00\right)$

Figura 5.9 - Gráficos de comparação das taxas de produtividade entre os diferentes tipos de uso das águas subterrâneas 
As melhores taxas de produtividade ocorrem para os usos de dessedentação de animais, irrigação e recreação, denominados de "outros", com as menores taxas de consumo e custo por volume produzido, respectivamente, $0,32 \mathrm{kWh} / \mathrm{m}^{3}$ e $\mathrm{R} \$ 0,07 / \mathrm{m}^{3}$, alcançando uma produção de $15,06 \mathrm{~m}^{3}$ para cada $\mathrm{R} \$ 1,00$ pago em energia elétrica (Tabela 5.1 e Figura 5.9). Ressalva-se, porém, que o pequeno universo de poços com essa finalidade de uso pode estar distorcendo a análise de produtividade.

As taxas de produtividade com valores intermediários ocorrem para os usos doméstico, industrial e comercial. Os usos domésticos e comerciais possuem taxas similares de consumo de energia por volume produzido, com valores de 0,35 e 0,36 kWh/m $\mathrm{m}^{3}$, respectivamente. $\mathrm{O}$ uso industrial possui uma taxa menos eficiente de produtividade, com valor de $0,52 \mathrm{kWh} / \mathrm{m}^{3}$ (Tabela 5.1 e Figura 5.9).

A diferença nos valores das tarifas propicia que as taxas de produtividade relativas ao custo de energia sejam piores para os usos domésticos, conforme poder ser observado nos gráficos da Figura 5.9. Comparativamente entre esses usos, o comercial possui as melhores taxas ( $\left.\mathrm{R} \$ 0,08 / \mathrm{m}^{3} ; 13,31 \mathrm{~m}^{3} / \mathrm{R} \$ 1,00\right)$, seguido pelo industrial $\left(\mathrm{R} \$ 0,11 / \mathrm{m}^{3} ; 9,24 \mathrm{~m}^{3} / \mathrm{R} \$ 1,00\right)$ e pelo doméstico $\left(\mathrm{R} \$ 0,12 / \mathrm{m}^{3} ; 8,63 \mathrm{~m}^{3} / \mathrm{R} \$ 1,00\right)$.

As piores taxas de produtividade, dentre todos os usos, estão relacionadas aos poços de abastecimento público, apresentando valores de $0,56 \mathrm{kWh} / \mathrm{m}^{3}, \quad \mathrm{R} \$ 0,13 / \mathrm{m}^{3}$ e $7,77 \mathrm{~m}^{3} / \mathrm{R} \$ 1,00$ (Tabela 5.1 e Figura 5.9).

Além dos parâmetros apresentados anteriormente, foi efetuado o cálculo do rendimento de cada sistema de bombeamento, aplicando-se a equação 5.5. Os valores de rendimento dos sistemas foram correlacionados com a taxa de consumo, conforme ilustrado na Figura 5.10.

A correlação entre a taxa de produtividade $\left(\mathrm{R} \$ / \mathrm{m}^{3}\right)$ e o rendimento do sistema de bombeamento $\left(\rho_{\mathrm{s}}\right)$ mostrou-se fortemente inversa (Figura 5.10), evidenciando que os sistemas com elevados rendimentos apresentam-se economicamente mais eficientes no consumo energético, ou seja, com menores valores da taxa de produtividade.

Nota-se que em todos os tipos de usos existem grande dispersão de poços ao longo da curva de correlação (Figura 5.10), indicando que em todos os setores são encontrados poços com baixos e altos rendimentos. 


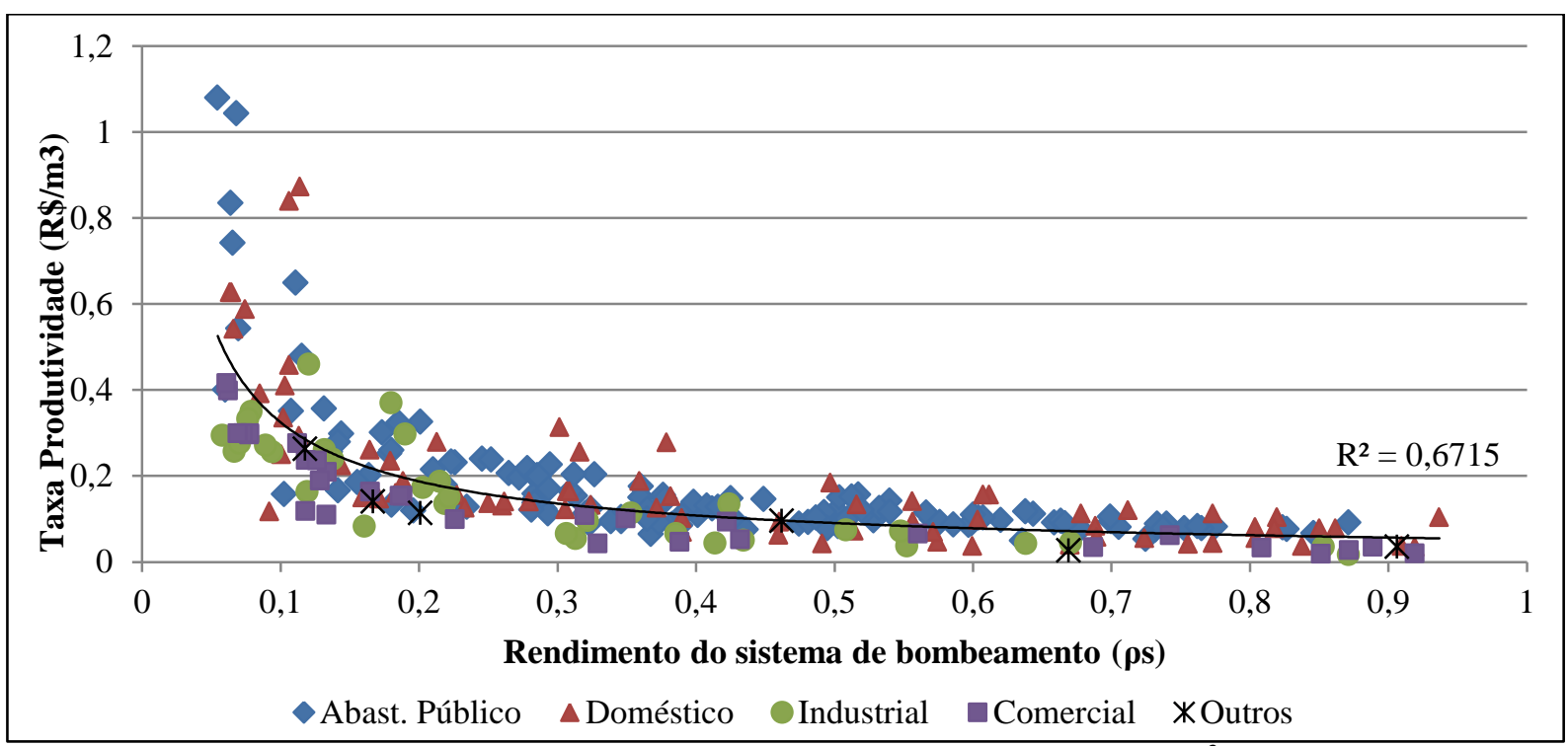

Figura 5.10 - Gráfico de correlação entre a taxa de produtividade $\left(\mathrm{R} \$ / \mathrm{m}^{3}\right)$ e o rendimento dos sistemas de bombeamento $\left(\rho_{\mathrm{s}}\right)$ em 273 poços do cadastro

Deve-se destacar que, conforme abordado do item 5.1, as teorias acerca dos cálculos de rendimentos e os aspectos conceituais sobre as perdas de carga, invariavelmente, não seriam esperados rendimentos muito elevados. No entanto, na Figura 5.10, pode-se observar rendimentos de até $95 \%$. Com os dados disponíveis, não é possível avaliar os motivos que influenciaram os altíssimos rendimentos (acima de 80\%) e, por isso, a abordagem desta pesquisa será sobre o rendimento médio dos sistemas de bombeamento.

Em análise a todo o elenco de poços com disponibilidade dos parâmetros de interesse e com foco na avaliação do rendimento médio dos sistemas de bombeamento, verificou-se que os dados de potência nominal das bombas variam de 0,75 a $21 \mathrm{~kW}$ e totalizam $2.138 \mathrm{~kW}$ instalados nos 273 poços, com potência média de $8 \mathrm{~kW}$ por bomba.

Considerando a potência instalada e aplicando-se a equação 5.8 foi calculado um consumo total de $709.217 \mathrm{kWh} /$ mês que propicia um custo mensal de energia elétrica estimado em R $\$ 160.071,90$ para a explotação, nos 273 poços, de $1.273 \times 10^{3} \mathrm{~m}^{3} / \mathrm{mês}$.

As taxas de produtividade calculadas para os dados totais de explotação, consumo e custo alcançaram valores de $0,56 \mathrm{kWh} / \mathrm{m}^{3}$ e $\mathrm{R} \$ 0,13 / \mathrm{m}^{3}$.

O rendimento médio dos sistemas de bombeamento dos 273 poços foi calculado em $38 \%$, considerando os valores médios de nível dinâmico $(H=68,20 \mathrm{~m})$, vazão $(\mathrm{Q}=15,86$ $\left.\mathrm{m}^{3} / \mathrm{h}\right)$ e potência $(7,8 \mathrm{kWh})$, aplicados na equação 5.5 .

Perroni e Wendland (2006) utilizaram uma abordagem semelhante à adotada no presente estudo para a avaliação de poços de abastecimento público em São Carlos, no 
interior do Estado de São Paulo. Os referidos autores calcularam rendimentos variando de $36 \%$ a 55\%, com média de 43\%, e avaliaram como uma condição de baixa eficiência, levando à proposição de adequações e melhorias visando elevar o rendimento médio do sistema de abastecimento de São Carlos para $65 \%$.

A representatividade do rendimento médio calculado nesta pesquisa será discutida em maior detalhe adiante, assim como os demais resultados obtidos com a avaliação desses 273 poços do cadastro. Entretanto, pode-se caracterizar como um rendimento de baixa eficiência energética.

$\mathrm{Na}$ ausência de valores de referência ideais para o rendimento de captações subterrâneas, esta pesquisa adota como meta de rendimento eficiente para a explotação do $\mathrm{SAB}$ um valor de $65 \%$, principalmente, com base nos rendimentos nominais de bombas submersas e também empregando a mesma meta adotada por Perroni (2005) e Perroni e Wendland (2006). A meta de rendimento arbitrada representaria um aumento de $71 \%$ no rendimento médio obtido nos poços do cadastro avaliados.

Essa taxa eficiente de rendimento arbitrada será aplicada na determinação do consumo de energia na explotação do $\mathrm{SAB}$, com foco na avaliação de possíveis externalidades provocadas pela intensa explotação existente em SJRP, conforme será demonstrado adiante.

\subsection{ESTIMATIVA DO CONSUMO DE ENERGIA ELÉTRICA NA EXPLOTAÇÃO DO SISTEMA AQUÍFERO BAURU EM SÃO JOSÉ DO RIO PRETO}

No presente estudo, a avaliação do consumo de energia na explotação das águas subterrâneas possui abrangência a quase todos os poços do município de SJRP e visa caracterizar possíveis externalidades à coletividade e aos usuários, causadas pelo uso intenso das águas subterrâneas do SAB. O modelo de uso das águas subterrâneas do SAB em SJRP afeta um dos principais parâmetros que impacta o consumo de energia que é o rebaixamento dos níveis potenciométricos e, consequentemente, aumentando a altura manométrica de bombeamento.

Conforme apresentado no item 5.1, diversos fatores influenciam o consumo de energia na explotação das águas subterrâneas. Entretanto, diante de informações escassas sobre muitos dos parâmetros que podem influenciar no consumo energético e considerando a escala 
da avaliação, este trabalho adotou uma abordagem sistemática para a estimativa dos custos de energia elétrica.

A estimativa do consumo de energia elétrica na explotação das águas do SAB em SJRP foi obtida a partir da equação 5.5 que calcula a potência requerida para o bombeamento de qualquer conjunto elevatório, neste caso, para a captação das águas subterrâneas. Os parâmetros de interesse são: a vazão do bombeamento $(\mathrm{Q})$, a altura manométrica $(\mathrm{H})$ e o rendimento do sistema $\left(\rho_{\mathrm{s}}\right)$. A seguir serão especificados os dados utilizados para os parâmetros de interesse citados acima.

O rendimento do sistema de bombeamento foi arbitrado em $65 \%$, conforme justificado anteriormente, no item 5.2.

Para as vazões de bombeamento foram utilizados os dados de vazão de explotação do cadastro de poços do DAEE (2008), registrados em volumes mensais, convertidos para volume por hora, atribuindo-se o regime de bombeamento de $15 \mathrm{~h} /$ dia para poços públicos e de $3 \mathrm{~h} /$ dia para os demais usos.

Vale destacar que, para os cenários hipotéticos que simularam explotações em diferentes vazões às registradas no cadastro de poços, foi adotada uma taxa de incremento da vazão de explotação constante para todos os poços, assim como praticado no desenvolvimento dos modelos de fluxo subterrâneo.

As alturas manométricas foram obtidas a partir de mapas potenciométricos gerados nas modelações numéricas do fluxo subterrâneo do SAB, demonstrados no item 3.7. Neste caso, as alturas manométricas foram adotadas como sendo a distância entre a profundidade do nível de água obtida na modelação e a superfície do terreno.

A superfície do terreno, ou seja, a topografia da área de interesse foi obtida através da geração de um modelo digital de elevação (MDE), apresentando na Figura 5.11, produzido em sistema de informações georreferenciadas, a partir de imagens SRTM (Shuttle Radar Topography Mission), disponibilizadas pela EMBRAPA. 


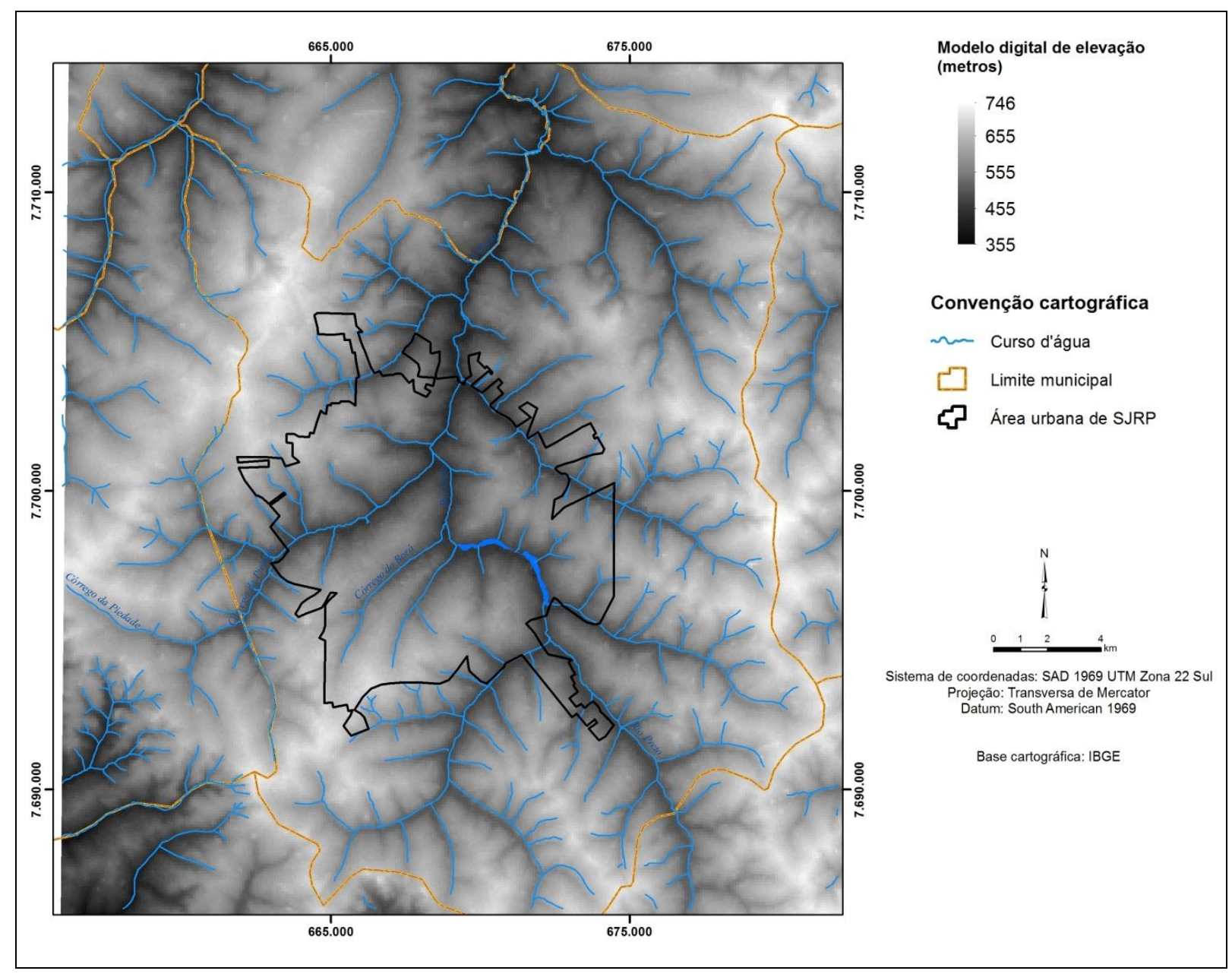

Figura 5.11 - Modelo digital de elevação (topografia) do terreno na área de estudo

A interpolação do MDE com modelo numérico de fluxo subterrâneo, realizada em sistema de informações georreferenciadas, foi executada com o uso do aplicativo ArcGIS, versão 10.0. O resultado da interpolação produziu o mapa residual oriundo da diferença de dados de altitudes dos dois modelos, obtendo-se a profundidade do nível de água na área de abrangência do modelo numérico.

A Figura 5.12 apresenta a ilustração esquemática do método utilizado na geração dos mapas de profundidade do nível de água (nível "C" da Figura 5.12) que correspondem ao resultado da subtração entre as cotas do MDE e as cotas potenciométricas do mapa gerado pelos modelos numéricos, respectivamente, níveis "A" e "B" da Figura 5.12. 


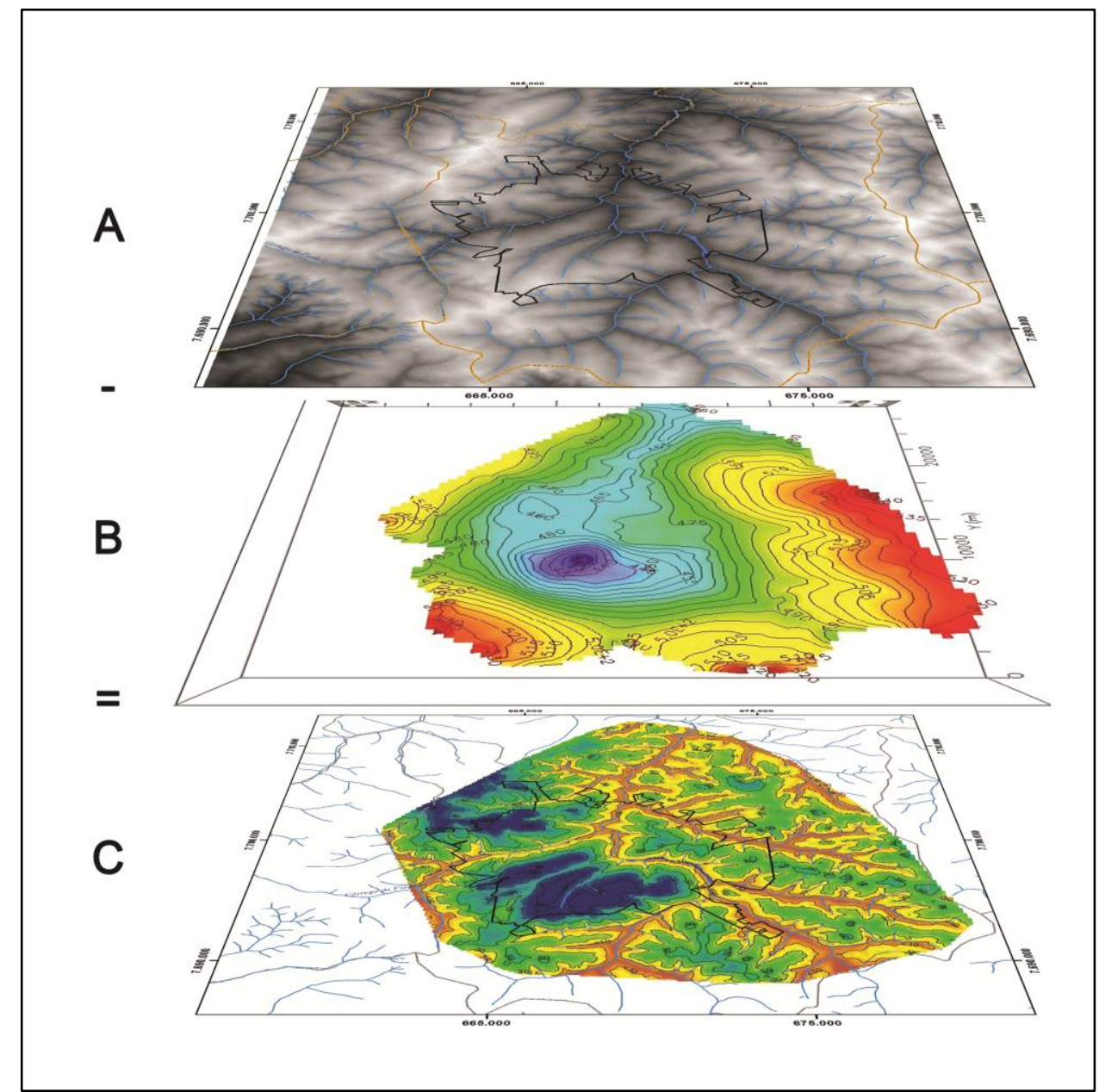

Figura 5.12 - Ilustração esquemática do método de geração dos mapas de profundidade do nível de água do SAB em SJRP (C), resultantes da diferença entre as cotas topográficas do modelo digital de elevação (A) e das cotas potenciométricas obtidas nos modelos numéricos de fluxo subterrâneo (B)

Os mapas gerados com o procedimento ilustrado na Figura 5.12 representam a profundidade da superfície potenciométrica que corresponde ao equilíbrio dinâmico alcançado pelos modelos numéricos, resultante da perturbação no regime de fluxo natural do SAB provocada pelo bombeamento dos poços. Desse modo, os mapas de profundidade da potenciometria refletem tanto condições similares aos fluxos naturais do SAB, onde a densidade de poços é pequena, bem como, os fortes efeitos de rebaixamento ocasionados pela intensa explotação existente, sobretudo, na região central da cidade com elevadíssima densidade de poços.

Conforme apresentado no item 3.7, os mapas potenciométricos de modelos numéricos de fluxo subterrâneo do SAB adotados nesta pesquisa foram: o cenário de bombeamento calculado nos estudos hidrogeológicos do DAEE (2008) e Wendland et al. (no prelo) e cenários modelados nos trabalhos realizados por Carvalho (2012) e Carvalho et al. (em 
preparação), no âmbito das pesquisas sobre a gestão das águas subterrâneas em SJRP, desenvolvidas no LAMO/CEPAS.

Os cenários de diferentes taxas de explotação modelados numericamente e avaliados para a determinação do custo de energia no bombeamento das águas subterrâneas são:

Cenário 1 - Volume total explotado de $98.000 \mathrm{~m}^{3} /$ dia, representando a explotação do ano base de 2008, calculada a partir dos dados de vazão registrados no cadastro de poços do DAEE (DAEE, 2008; Wendland et al., no prelo);

Cenário 2 - Volume total explotado de $160.000 \mathrm{~m}^{3} / \mathrm{dia}$, correspondendo ao cenário hipotético desenvolvido por Carvalho (2012) que, nesta pesquisa está considerado como o provável cenário atual de bombeamento em SJRP, considerando que o aumento em relação ao cenário 1 se deve pelo crescimento natural do consumo de água subterrânea de 2008 até o momento e pela provável existência de poços que não foram incluídas no cadastro do DAEE;

Cenário 3 - Volume total explotado de $240.000 \mathrm{~m}^{3} /$ dia, correspondendo ao cenário hipotético desenvolvido por Carvalho (2012), no qual o volume explotado é 50\% superior às taxas do cenário 2, ou seja, representaria um crescimento da explotação atual em $50 \%$.

Cenário 4 - Volume total explotado de $47.000 \mathrm{~m}^{3} / \mathrm{dia}$, correspondendo ao cenário hipotético desenvolvido por Carvalho (2012), no qual está considerada somente a explotação dos poços de abastecimento público com vazões de bombeamento da base de dados de 2008 .

Apesar de as áreas dos modelos possuírem diferentes contornos, para efeito dos cálculos do consumo de energia elétrica, foi adotada a área de intersecção dos modelos (Figura 3.23), visando permitir a comparação do consumo de energia obtido para os diferentes cenários avaliados.

$\mathrm{Na}$ área de intersecção dos modelos numéricos existem 1.882 poços em operação que possuem dados de vazão de bombeamento para cada cenário de explotação avaliado e, a partir da plotagem nos mapas de profundidade do nível de água, foram determinadas as alturas manométricas, também específicas para cada poço em cada cenário. Desse modo, foram obtidos os parâmetros de interesse para a aplicação da equação do cálculo do consumo de energia (equação 5.5).

As Figuras 5.13 a 5.16 demonstram os mapas de profundidade do nível de água, obtidos com o procedimento ilustrado na Figura 5.12, respectivamente, para os cenários 1 a 4 e, a seguir, serão apresentados os parâmetros e valores relativos aos cálculos do consumo de energia, compilados na Tabela 5.2. 
Tabela 5.2 Parâmetros de interesse e valores dos cálculos de consumo de energia elétrica nos cenários de explotação do SAB em SJRP

\begin{tabular}{|c|c|c|c|c|c|}
\hline Parâmetro & Unidade & Cenário 1 & Cenário 2 & Cenário 3 & Cenário 4 \\
\hline $\mathrm{H}^{*} \mathrm{mx}$ & $\mathrm{m}$ & 104,61 & 107,35 & 135,00 & 70,00 \\
\hline $\mathrm{H}^{*} \mathrm{md}$ & $\mathrm{m}$ & 52,22 & 56,03 & 71,80 & 42,78 \\
\hline Q md. & $\mathrm{m}^{3} / \mathrm{h}$ & 11,32 & 19,15 & 28,64 & 17,10 \\
\hline $\mathrm{CE}_{\mathrm{i}} \mathrm{mx}$. & $\mathrm{kWh}$ & 30,93 & 71,02 & 139,97 & 8,19 \\
\hline $\mathrm{CE}_{\mathrm{i}} \mathrm{md}$. & $\mathrm{kWh}$ & 2,38 & 4,29 & 8,18 & 2,04 \\
\hline Q mn. & $\mathrm{m}^{3} / \mathrm{mês}$ & 2.969 .296 & 4.872 .081 & 7.308 .122 & 1.426 .585 \\
\hline $\mathrm{CE}_{\mathrm{t}} \mathrm{mn}$. & kWh/mês & 670.178 & 1.167 .782 & 2.228 .791 & 169.913 \\
\hline $\mathrm{C}$ mn. & $\mathrm{R} \$ /$ mês & 162.393 & 293.058 & 558.362 & 37.381 \\
\hline
\end{tabular}

H mx.: altura manométrica máxima; H md.: altura manométrica média; Q md.: vazão de explotação média; $\mathrm{CE}_{\mathrm{i}} \mathrm{mx}$.: consumo de energia elétrica máximo individual por equipamento; $\mathrm{CE}_{\mathrm{i}} \mathrm{md}$.: consumo de energia elétrica médio individual por equipamento; $\mathrm{Q}$ m: vazão de explotação total mensal; $\mathrm{CE}_{\mathrm{t}} \mathrm{mn}$.: consumo de energia elétrica total por mês; $\mathrm{C}$ mn.: custo mensal de energia elétrica.

*o parâmetro de altura manométrica $(\mathrm{H})$ corresponde à profundidade do nível de água. 


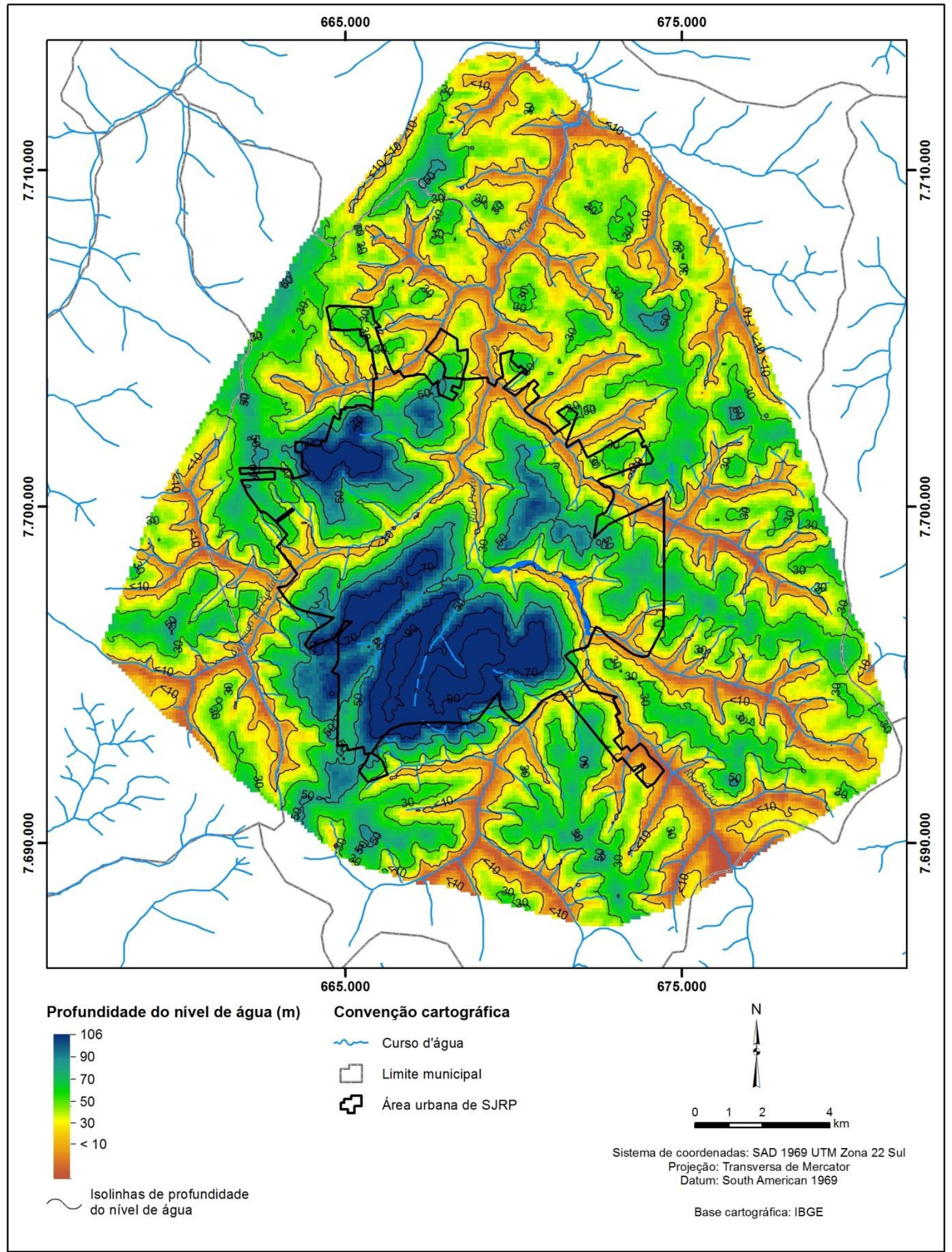

Figura 5.13 - Mapa de profundidade do nível de água do SAB em SJRP referente à explotação de $98.000 \mathrm{~m}^{3} /$ dia (Cenário 1) 


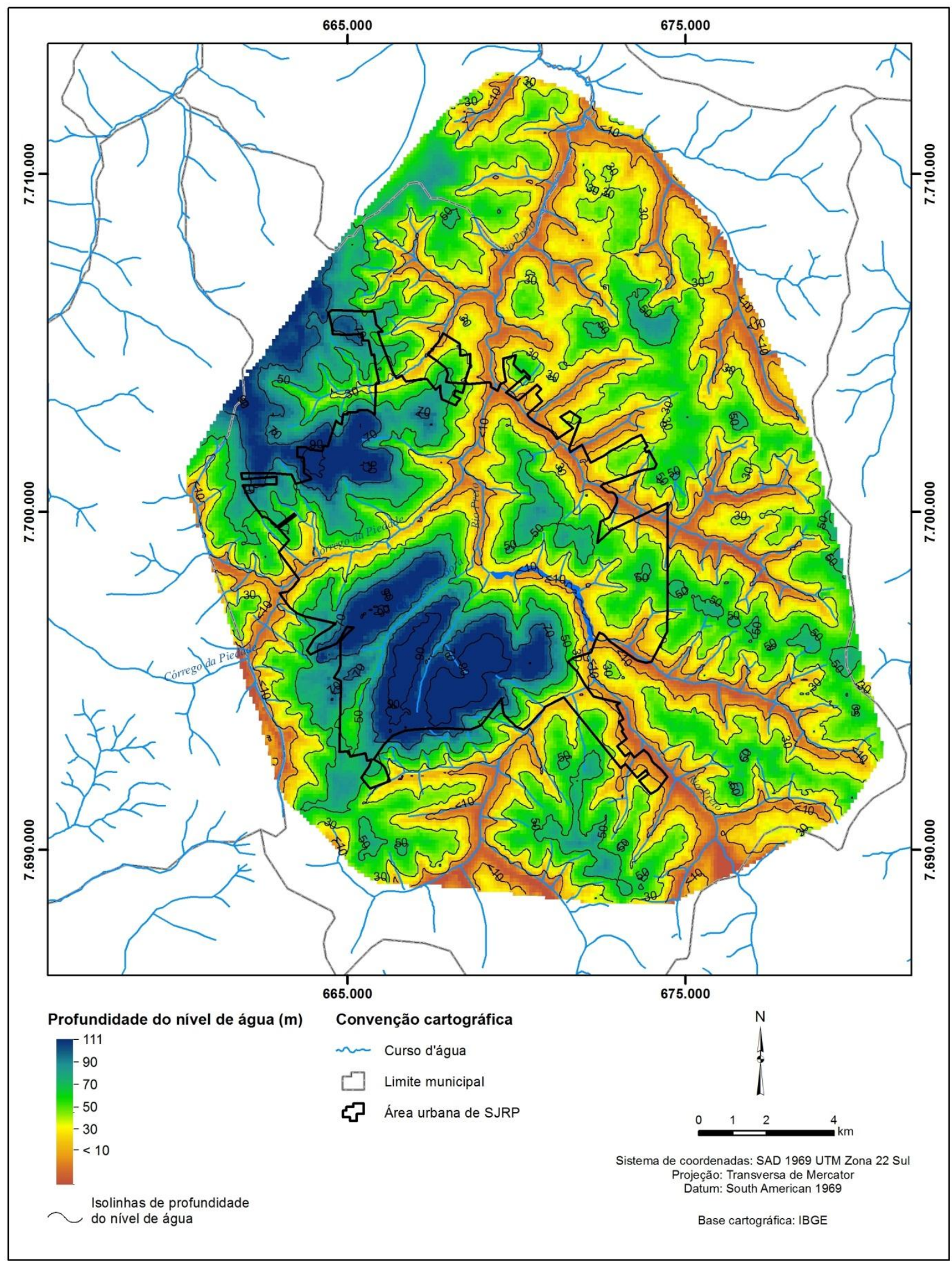

Figura 5.14 - Mapa de profundidade do nível de água do SAB em SJRP referente à explotação de $160.000 \mathrm{~m}^{3} /$ dia (Cenário 2) 


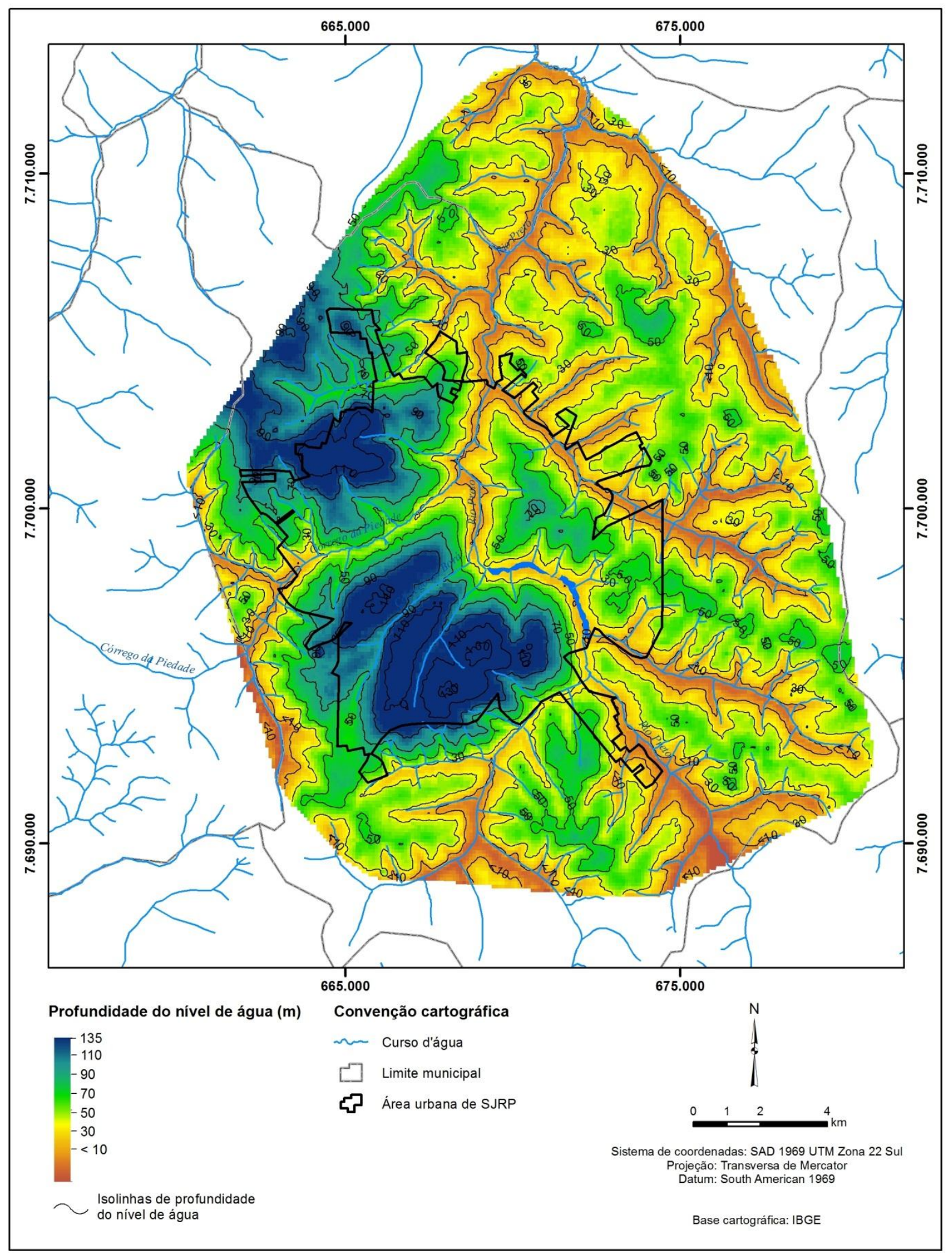

Figura 5.15 - Mapa de profundidade do nível de água do SAB em SJRP referente à explotação de $240.000 \mathrm{~m}^{3} /$ dia (Cenário 3) 


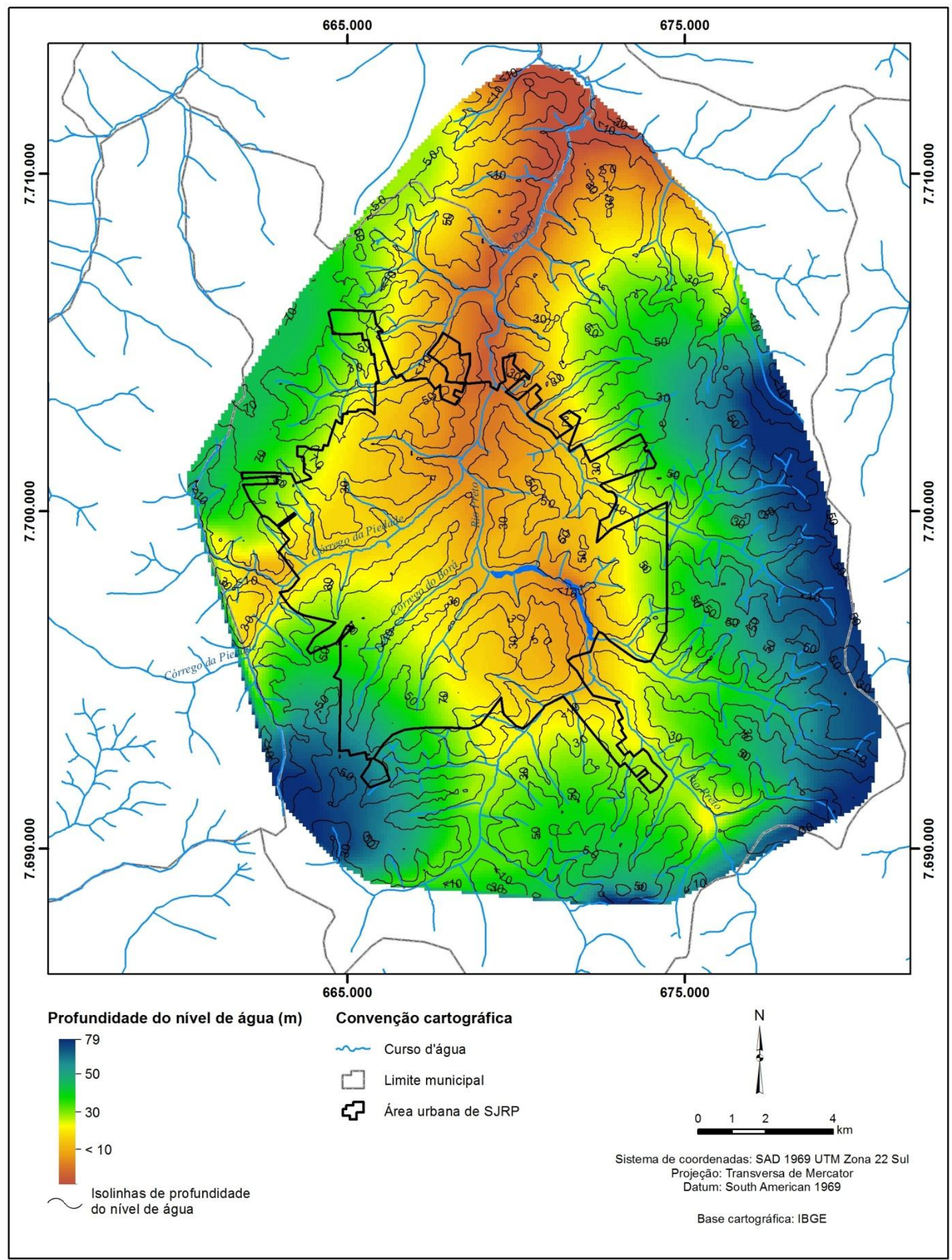

Figura 5.16 - Mapa de profundidade do nível de água do SAB em SJRP referente à explotação de $47.000 \mathrm{~m}^{3} /$ dia somente pelos poços de abastecimento público (Cenário 4) 
O cenário 1 possui profundidade média do nível de água de $52,22 \mathrm{~m}$ e rebaixamento máximo de 104,61 m, situado na região central de SJRP (Figura 5.13), para uma explotação total de $2.969 \times 10^{3} \mathrm{~m}^{3} /$ mês e vazão de bombeamento média de $11,32 \mathrm{~m}^{3} / \mathrm{h}$. A aplicação dos cálculos de consumo de energia, considerando a eficiência do sistema arbitrada em 65\%, determinou o consumo médio por poço de $2,38 \mathrm{kWh}$ e consumo total de $670 \mathrm{MWh} / \mathrm{mês}$. O custo mensal de energia elétrica, adotando-se as tarifas especificadas no item 5.2, foi totalizado em R\$162.393,39.

No Cenário 2, a profundidade média do nível de água foi de 56,03 m e o rebaixamento máximo foi de $107,35 \mathrm{~m}$ (Figura 5.14), para uma explotação total de $4.872 \times 10^{3} \mathrm{~m}^{3} / \mathrm{mês}$ e vazão de bombeamento média de $19,15 \mathrm{~m}^{3} / \mathrm{h}$. O consumo de energia médio foi calculado em 4,29 kWh por poço, o consumo total, em 1.168 MWh/mês e o custo mensal de energia elétrica foi totalizado em $\mathrm{R} \$ 293.058,18$.

No Cenário 3, a profundidade média do nível de água foi de 71,80 m e o rebaixamento máximo foi de $135,00 \mathrm{~m}$, para uma explotação total de $7.308 \times 10^{3} \mathrm{~m}^{3} / \mathrm{mês}$ e vazão de bombeamento média de $28,64 \mathrm{~m}^{3} / \mathrm{h}$. O consumo de energia médio foi calculado em $8,18 \mathrm{kWh}$ por poço, o consumo total, em 2.229 MWh/mês e o custo mensal de energia elétrica foi totalizado em R $\$ 558.362,18$. Nesse cenário, pode-se observar que os intensos rebaixamentos se estendem para regiões circunvizinhas ao centro da cidade (Figura 5.15).

No Cenário 4, a profundidade média do nível de água foi de $42,78 \mathrm{~m}$ e o rebaixamento máximo foi de $70,00 \mathrm{~m}$, para uma explotação total de $1.427 \times 10^{3} \mathrm{~m}^{3} / \mathrm{mês}$ e vazão de bombeamento média de $17,10 \mathrm{~m}^{3} / \mathrm{h}$. O consumo de energia médio foi calculado em $2,04 \mathrm{kWh}$ por poço, o consumo total, em $170 \mathrm{MWh} / \mathrm{mês}$ e o custo mensal de energia elétrica foi totalizado em $\mathrm{R} \$ 37.381,81$.

Na Figura 5.16, relativa ao Cenário 4, pode-se observar que as maiores profundidades do nível de água estão situadas nas áreas de recarga do aquífero, próximas aos divisores das microbacias hidrográficas. Na região central da cidade, as isolinhas de profundidade não formam depressões circulares, aparecem contornando as drenagens e posicionam-se muito semelhantes às equipotenciais verificadas no mapa potenciométrico de fluxo natural (Figura $3.24)$.

O Cenário 4 é decorrente da simulação de bombeamento de um elenco diferente de poços, em relação aos demais cenários. Desse modo, vale uma análise comparativa dos parâmetros de interesse e valores de consumo, exclusivamente, dos poços públicos nos diferentes cenários, conforme compilado na Tabela 5.3. 
Tabela 5.3 - Parâmetros de interesse e valores dos cálculos de consumo de energia elétrica dos poços públicos nos cenários de explotação do SAB em SJRP

\begin{tabular}{l|c|r|r|r|r}
\hline \multicolumn{1}{c|}{ Parâmetro } & Unidade & \multicolumn{1}{c|}{ Cenário 1 } & \multicolumn{1}{c}{ Cenário 2 } & \multicolumn{1}{c}{ Cenário 3 } & Cenário 4 \\
\hline $\mathrm{H}^{*} \mathrm{mx}$. & $\mathrm{m}$ & 103,55 & 106,62 & 132,05 & 70,00 \\
\hline $\mathrm{H}^{*} \mathrm{md}$. & $\mathrm{m}$ & 55,81 & 61,32 & 78,32 & 42,78 \\
\hline $\mathrm{Q} \mathrm{md}$. & $\mathrm{m} 3 / \mathrm{h}$ & 15,72 & 23,94 & 35,90 & 17,10 \\
\hline $\mathrm{CE}_{\mathrm{i}} \mathrm{mx}$. & $\mathrm{kWh}$ & 18,25 & 26,04 & 48,84 & 8,19 \\
\hline $\mathrm{CE}_{\mathrm{i}} \mathrm{md}$. & $\mathrm{kWh}$ & 3,90 & 6,44 & 12,35 & 2,04 \\
\hline $\mathrm{Q} \mathrm{mn}$. & $\mathrm{m} 3 / \mathrm{mês}$ & 1.311 .022 & 1.997 .218 & 2.995 .828 & 1.426 .585 \\
\hline $\mathrm{CE} E_{\mathrm{t} n}$. & $\mathrm{kWh} / \mathrm{mês}$ & 325.973 & 537.887 & 1.030 .849 & 169.913 \\
\hline $\mathrm{C} \mathrm{mn}$. & $\mathrm{R} \$ \mathrm{mês}$ & 71.714 & 118.335 & 226.787 & 37.381 \\
\hline
\end{tabular}

H mx.: altura manométrica máxima; H md.: altura manométrica média; Q md.: vazão de explotação média; $\mathrm{CE}_{\mathrm{i}} \mathrm{mx}$.: consumo de energia elétrica máximo individual por equipamento; $\mathrm{CE}_{\mathrm{i}} \mathrm{md}$.: consumo de energia elétrica médio individual por equipamento; $\mathrm{Q}$ mn: vazão de explotação total mensal; $\mathrm{CE}_{\mathrm{t}} \mathrm{mn}$.: consumo de energia elétrica total por mês; $\mathrm{C}$ mn.: custo mensal de energia elétrica.

*o parâmetro de altura manométrica $(\mathrm{H})$ corresponde à profundidade do nível de água.

Os resultados dos cálculos do consumo de energia elétrica na explotação das águas do SAB em SJRP serão avaliados adiante, para os diferentes cenários simulados, discutindo-se a influência da intensidade da explotação no sobrecusto de energia elétrica e, consequentemente, na avaliação de externalidades associadas aos modelos de uso das águas subterrâneas. 


\section{DISCUSSÕES DE RESULTADOS}

Os resultados alcançados nesta pesquisa sobre a explotação das águas subterrâneas do SAB e o consumo de energia elétrica no bombeamento permitiram discussões e avaliações do padrão de consumo de água em SJRP, da influência do modelo de uso das águas subterrâneas nos custos de energia elétrica e da ocorrência de superexplotação.

\subsection{A EXPLOTAÇÃO DO SAB E O PADRÃO DE CONSUMO DE ÁGUA EM SJRP}

Os volumes explotados do Sistema Aquífero Bauru em São José do Rio Preto foram calculados com base em dados consistentes, em grande parte, medidos. Desse modo, foi possível obter análises seguras sobre o padrão de consumo de água neste município, bem como de indicadores relacionados ao uso das águas subterrâneas e à operação dos poços.

$\mathrm{O}$ volume explotado do SAB em SJRP é de $3.727 \times 10^{3} \mathrm{~m}^{3} / \mathrm{mês}$ ou $122.521 \mathrm{~m}^{3} / \mathrm{dia}$, referente à somatória das vazões de explotação de 1.953 poços em operação, de acordo com o cadastro do DAEE (2008). Os volumes explotados estão distribuídos nos diferentes usos das águas subterrâneas, conforme demonstrado na Figura 6.1.

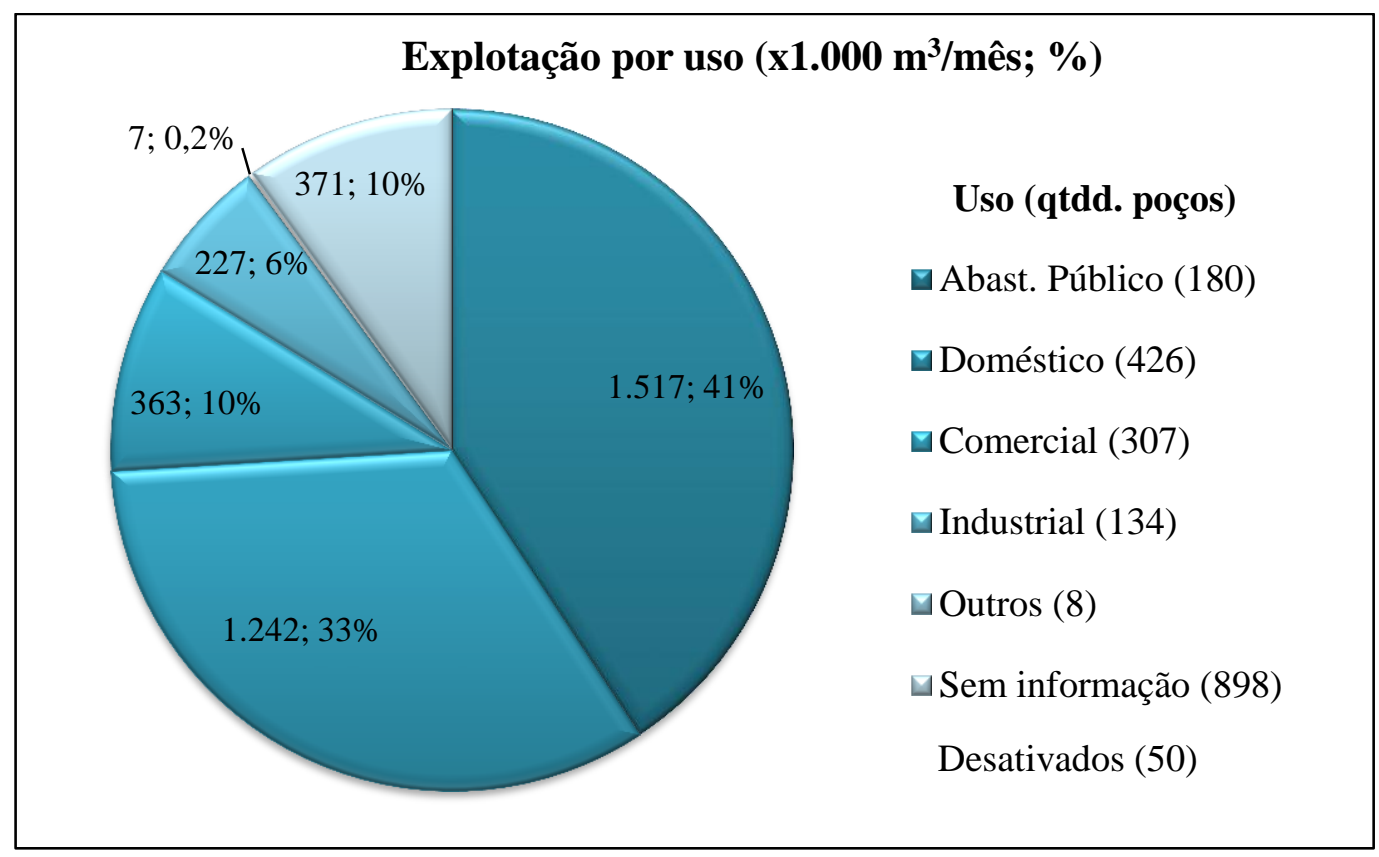

Figura 6.1 - Volumes explotados do SAB em SJRP por finalidade de uso das águas subterrâneas 
A explotação calculada dos poços de abastecimento público é de $1.517 \times 10^{3} \mathrm{~m}^{3} / \mathrm{mês}$ e representa $41 \%$ de toda a explotação do SAB em SJRP (Figura 6.1). A média da vazão nesses poços, de acordo com o cadastro do DAEE (2008), é de $19 \mathrm{~m}^{3} / \mathrm{h}$, permitindo determinar um regime médio de bombeamento de aproximadamente $15 \mathrm{~h} / \mathrm{dia}$.

Os poços de abastecimento público explotam o equivalente a $49.875 \mathrm{~m}^{3} / \mathrm{dia}$, sendo que, esse volume calculado é 6,5\% superior aos dados oficiais disponibilizados pelo Semae para o ano de 2008, que informaram uma produção diária de $46.769 \mathrm{~m}^{3}$ (PMSJRP, 2009).

O volume oficial informado pelo Semae é compatível com os dados de vazão medida, entretanto, corresponde a um valor subestimado do volume de água produzido pelo sistema público de abastecimento de SJRP.

A Figura 6.1. mostra que o uso doméstico é o segundo em volume explotado, com $33 \%$ do total, seguido pelos usos comercial e industrial, respectivamente, com $10 \%$ e $6 \%$ do volume total explotado do SAB. Praticamente a totalidade dos poços com essas finalidades de uso são de propriedade particular.

Deve-se notar também que $371 \times 10^{3} \mathrm{~m}^{3} / \mathrm{mês}$, equivalentes a $10 \%$ de todo o volume explotado, não possuem informação sobre a finalidade de uso. Acredita-se que a grande maioria destes poços sem informação tenha a finalidade de uso doméstico e comercial, seguindo o padrão das informações disponíveis no cadastro de poços.

$\mathrm{O}$ volume explotado pelos poços com diversas finalidades de uso totaliza $2.210 \times 10^{3}$ $\mathrm{m}^{3} /$ mês. A vazão média nesses poços é de $13 \mathrm{~m}^{3} / \mathrm{h}$, de acordo com o cadastro do DAEE (2008), permitindo determinar um regime médio de bombeamento de cerca de $3 \mathrm{~h} / \mathrm{dia}$.

Os poços privados com diversas finalidades de uso respondem por uma explotação equivalente a $26.516 \times 10^{3} \mathrm{~m}^{3} / \mathrm{ano}, 72.646 \mathrm{~m}^{3} / \mathrm{dia}$ ou $0,85 \mathrm{~m}^{3} / \mathrm{s}$, sendo que, esse volume não está considerado em nenhum documento que contabiliza o consumo de água neste município.

A Tabela 6.1 apresenta o volume total de água consumido em SJRP, de 152.530 $\mathrm{m}^{3} /$ dia, obtido com base nos cálculos da explotação do SAB determinados no presente estudo e nos dados do Semae sobre a produção do sistema público de abastecimento. 
Tabela 6.1 - Cálculo do consumo de água em SJRP

\begin{tabular}{l|r}
\hline \multicolumn{1}{c|}{ Descritivo } & \multicolumn{1}{c}{ Volume (m3/dia) } \\
\hline Abastecimento Público & 49.875 \\
\hline Sistema Aquífero Bauru $^{1}$ & 37.649 \\
\hline Sistema Aquífero Guarani $^{2}$ & 30.156 \\
\hline Rio Preto $^{2}$ & 117.680 \\
\hline Volume Produzido (T1) $^{2}$ & 37.796 \\
\hline Perdas $^{3}$ & 79.884 \\
\hline Volume Consumido (T2) & \\
\hline
\end{tabular}

\begin{tabular}{l|r}
\multicolumn{2}{l|}{ Abastecimento Privado } \\
\hline Sistema Aquífero Bauru ${ }^{4}$ (T3) & 72.646 \\
\hline Totais & 190.326 \\
\hline Produzido (T1+T3) & 152.530 \\
\hline Consumido (T2+T3)
\end{tabular}

1-Volume explotado do SAB pelos poços de abastecimento público, conforme cálculo demonstrado no item 3.5.3 deste trabalho;

2-Volumes produzidos pelo sistema de abastecimento público, de acordo com dados de 2008 fornecidos pelo Semae (PMSJRP, 2009);

3-Volume de perdas de água do sistema de abastecimento público, conforme cálculo apresentado no item 3.5.1 deste trabalho, baseado em informações de 2008 disponibilizadas pelo Semae (PMSJRP, 2009);

4-Volume explotado do SAB pelos poços privados com diversas finalidades de usos da água, conforme cálculo demonstrado no item 3.5.3 deste trabalho.

T1 - volume total produzido pelo sistema de abastecimento público correspondente à somatória das três fontes hídricas (SAG, SAB rio Preto);

T2 - total consumido do abastecimento público, correspondendo à diferença do volume produzido e das perdas;

T3 - total produzido e consumido das captações do SAB pelos poços particulares;

A análise da Tabela 6.1 permite observar que as águas subterrâneas respondem por $84 \%$ da produção de água para o suprimento às demandas de SJRP e que somente o SAB fornece $64 \%$ do total produzido.

Adotando-se o volume total consumido (Tabela 6.1) e considerando uma população de 400.000 habitantes, pode-se calcular uma taxa de consumo de água em São José do Rio Preto de 381 1/hab.dia. Esta estimativa é 116\% superior à taxa média de consumo para o Estado de São Paulo, de 176 1/hab.dia (SNIS, 2011), evidenciando um exagerado consumo em SJRP 
que, provavelmente, inclui usos desregrados e desperdícios. Alguns trabalhos de hidrogeologia (BARCHA, 1998; DAEE, 2008) também indicaram a ocorrência de excessivo consumo de água em SJRP, destacando a existência de contribuições particulares no suprimento às demandas hídricas.

Embora o cenário de existência de um grande número de poços privados seja comum nos centros urbanos brasileiros e, consequentemente, contribui com o padrão de consumo dessas localidades, acredita-se que, de modo geral, estes dados não estão apresentados nos levantamentos oficiais de abastecimento e consumo de água, conforme avaliado no caso de São José do Rio Preto. Desse modo, infere-se que, da mesma maneira que são subestimados os dados oficiais sobre a quantidade de poços existentes, também são as taxas de consumo per capta de água, sobretudo, nas regiões e/ou localidades com disponibilidade de águas subterrâneas.

Avalia-se também que os usos da água subterrânea, desconsiderando o abastecimento público, correspondem a 59\% do volume explotado do SAB em SJRP, na grande maioria dos casos, proveniente de poços particulares de residências, condomínios e empreendimentos diversos. Esta análise reflete a elevada importância da iniciativa privada no suprimento às demandas de água da população e do desenvolvimento econômico riopretense, respondendo por $48 \%$ do volume total consumido no município.

A discussão acima permite afirmar que o suprimento de água de SJRP é, no atual momento, fortemente dependente das alternativas individuais particulares. A constatação apresentada não indica, necessariamente, precariedade do sistema de abastecimento público. O cenário de intenso desenvolvimento da infraestrutura hídrica privada parece ter ocorrido à revelia do planejamento do poder público, provavelmente motivado pela adoção de alternativa de menor custo na obtenção de água por parte de muitos usuários.

Independentemente das razões que levaram ao modelo atual de uso da água subterrânea do SAB em SJRP, as iniciativas particulares custearam parte dos investimentos de implantação da infraestrutura hídrica de suprimento de água, diminuindo o custo coletivo, realizado por meio do poder público para esta finalidade. De outro modo, o poder público deveria prover 840 1/s, além dos 925 1/s produzidos, em substituição ao suprimento particular de água.

Apesar de a implantação das alternativas individuais de abastecimento de água ter representado uma economia ao custo coletivo de infraestrutura hídrica, o desenvolvimento desse modelo de uso das águas subterrâneas ocorreu à margem das medidas de controle e gestão, propiciando diversas consequências indesejáveis, tais como: o elevado índice de poços 
clandestinos; prováveis ocorrências de usos desregrados e desperdícios do recurso hídrico e os efeitos de fortes rebaixamentos dos níveis potenciométricos do SAB. Desse modo, a possível economia gerada com a individualização de parte dos custos de infraestrutura hídrica, provavelmente foi anulada pelas externalidades provocadas pela intensa explotação das águas subterrâneas, sobretudo, se considerar os efeitos ambientais associados que podem provocar irreversíveis comprometimentos da disponibilidade hídrica do aquífero.

O cenário ideal, de acordo com a avaliação deste estudo, seria pela continuidade do uso múltiplo das águas subterrâneas, ou seja, mantendo-se a participação das iniciativas individuais de implantação de parte da infraestrutura hídrica, entretanto, em um cenário de efetivo controle, fiscalização e gestão da explotação e do uso sustentáveis dos recursos hídricos subterrâneos do SAB.

\subsection{O MODELO DE USO DAS ÁGUAS SUBTERRÂNEA DO SAB EM SJRP E OS EFEITOS NO CUSTO DE ENERGIA ELÉTRICA NA EXPLOTAÇÃO}

Os resultados alcançados com a análise do consumo de energia elétrica na explotação das águas subterrâneas do SAB em SJRP constataram a ocorrência de incrementos no consumo e no custo de energia elétrica advindos do uso intenso dos recursos hídricos subterrâneos.

Os aumentos nas despesas com energia elétrica podem ser carcaterizados como externalidades provocadas pelo modelo de desenvolvimento da explotação das águas subterrâneas e atingem direta ou indiretamente todos os usuários desse recurso hídrico.

Os resultados permitiram avaliar também a existência de externalidades provocadas pelo uso particular das águas subterrâneas à coletividade. Assim, a captação por meio dos poços privados incrementam as despesas com energia elétrica na captação dos poços públicos, aumentando os custos da empresa de saneamento, neste caso o Semae, e, consequentemente, dos usuários do sistema público de abastecimento.

Além das externalidades provocadas pelo modelo de uso das águas subterrâneas, avaliou-se também existência de custos extras de energia provocados pelo baixo desempenho dos sistemas de bombeamento instalados nos poços.

Os principais resultados alcançados nesta pesquisa, sumarizados na introdução deste tópico, serão demonstrados e discutidos detalhadamente a seguir. 


\subsubsection{Avaliação das externalidades no custo de energia elétrica provocadas pelo modelo de} explotação das águas subterrâneas

A avaliação da influência dos intensos usos da água subterrânea no consumo da energia elétrica do bombeamento foi possível pela comparação de diferentes cenários de explotação com diferentes efeitos na potenciometria do SAB, a partir de um mesmo elenco de poços.

As modelações numéricas dos cenários 1, 2 e 3 representaram, respectivamente, a explotação de $98.000 \mathrm{~m}^{3} /$ dia, $160.000 \mathrm{~m}^{3} /$ dia e $240.000 \mathrm{~m}^{3} /$ dia, para um elenco de 1.882 poços, dispostos em uma área de $340 \mathrm{~km}^{2}$. O método utilizado para a determinação do consumo de energia elétrica na explotação, bem como, os valores dos parâmetros de interesse e de consumo de energia foram apresentados detalhadamente no item 5.3.

A avaliação da energia elétrica consumida no bombeamento dos poços nos diferentes cenários mostrou que ocorre influência da intensa explotação das águas subterrâneas no aumento do consumo e, consequentemente, dos custos de energia elétrica no bombeamento. Os valores de vazão de explotação, do consumo e do custo de energia elétrica (Tabela 5.2) foram plotados no gráfico da Figura 6.2, permitindo a comparação entre os 3 cenários avaliados.

Deve-se mencionar que, por conveniência à demonstração dos valores, o consumo de energia, por vezes, será apresentado em megawatts·hora (MWh), no caso da Figura 5.3, em megawatts'hora por mês (MWh/mês).

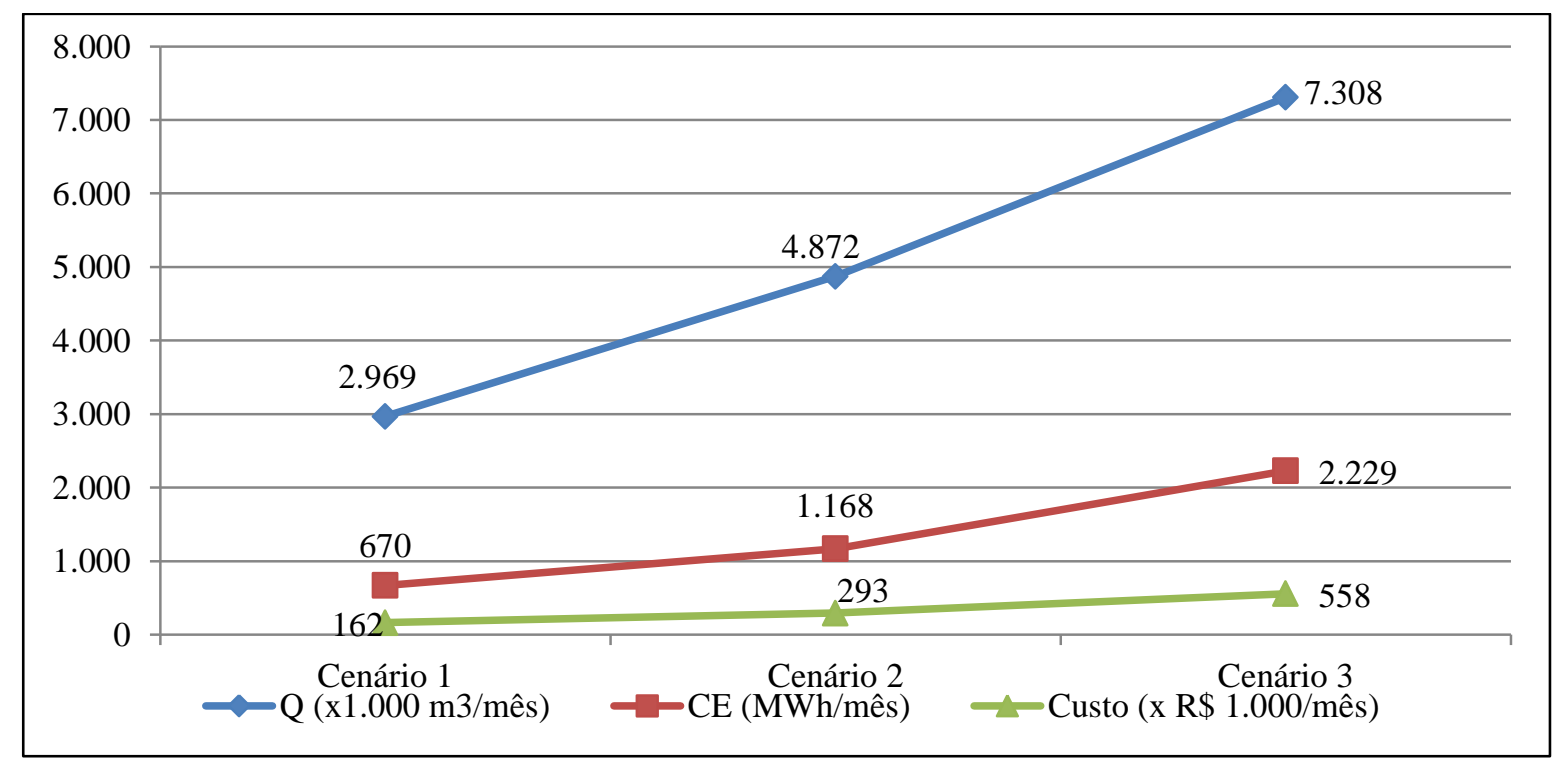

Figura 6.2 - Gráfico de comparação entre os cenários de simulação da explotação do SAB em SJRP com a demonstração da vazão de explotação, consumo e o custo de energia elétrica 
Na Figura 6.2 pode-se observar que a intensificação da explotação provoca aumentos do consumo e do custo de energia em maiores proporções. Nota-se que, enquanto a explotação aumentou em uma taxa de $146 \%$, do cenário 1 para o cenário 3 , o consumo de energia aumentou $232 \%$ e os custos se elevaram a uma taxa de $244 \%$.

As profundidades médias dos níveis de água obtidas foram de 52,22, 56,03 e 71,80 m, respectivamente, nos cenários 1, 2 e 3 (Tabela 5.2), mostrando que o aumento da explotação também provocou a intensificação dos rebaixamentos dos níveis potenciométricos.

As análises apresentadas anteriormente permitem constatar que os efeitos de rebaixamento dos níveis potenciométricos, característicos de regimes de uso intenso ou de superexplotação das águas subterrâneas, provocam aumentos nos custos de explotação.

A Figura 6.3 evidencia a fortíssima correlação entre os custos mensais com energia elétrica e a profundidade média do nível de água, demonstrando que a intensificação dos rebaixamentos nos níveis potenciométricos provocados pelo modelo de uso da água subterrânea influenciam no aumento dos custos de energia elétrica na explotação.

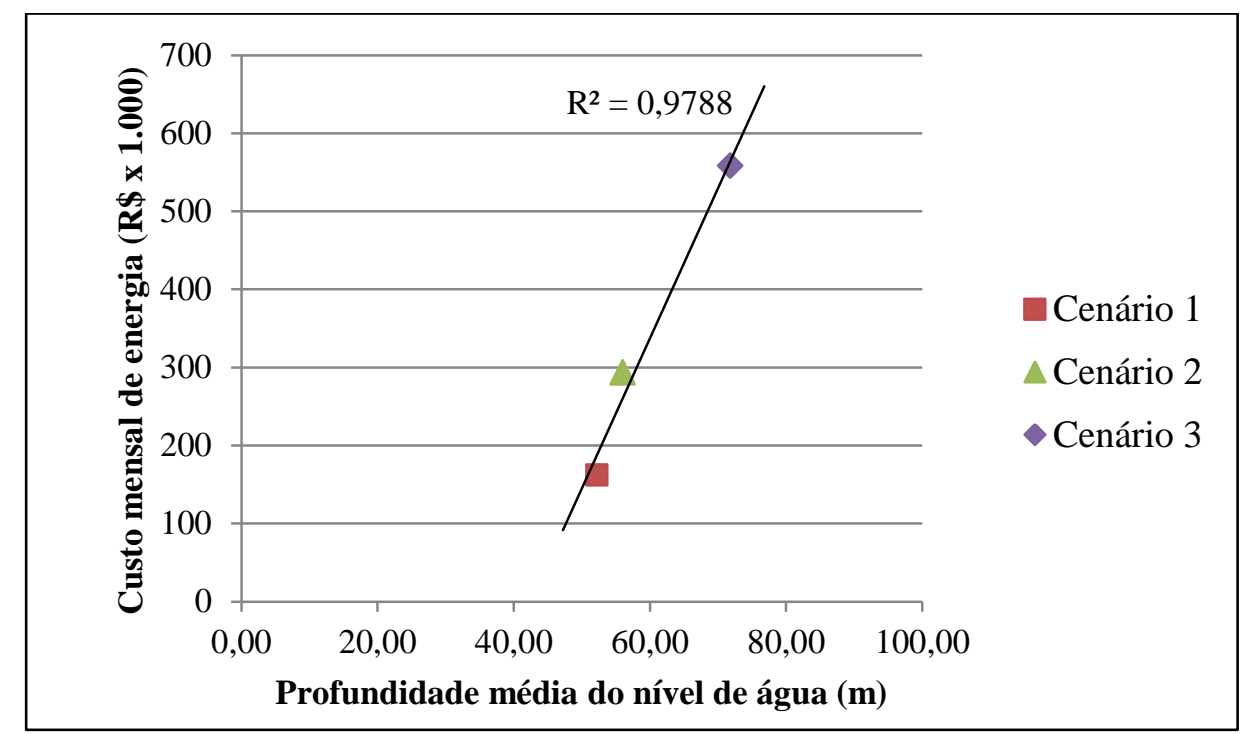

Figura 6.3 - Gráfico da correlação entre o custo de energia elétrica na explotação das águas subterrâneas e a profundidade média do nível de água 
A diminuição na eficiência de produtividade, observada nas diferentes taxas de produtividades mostradas na Figura 6.4, também evidencia o aumento do custo de explotação.

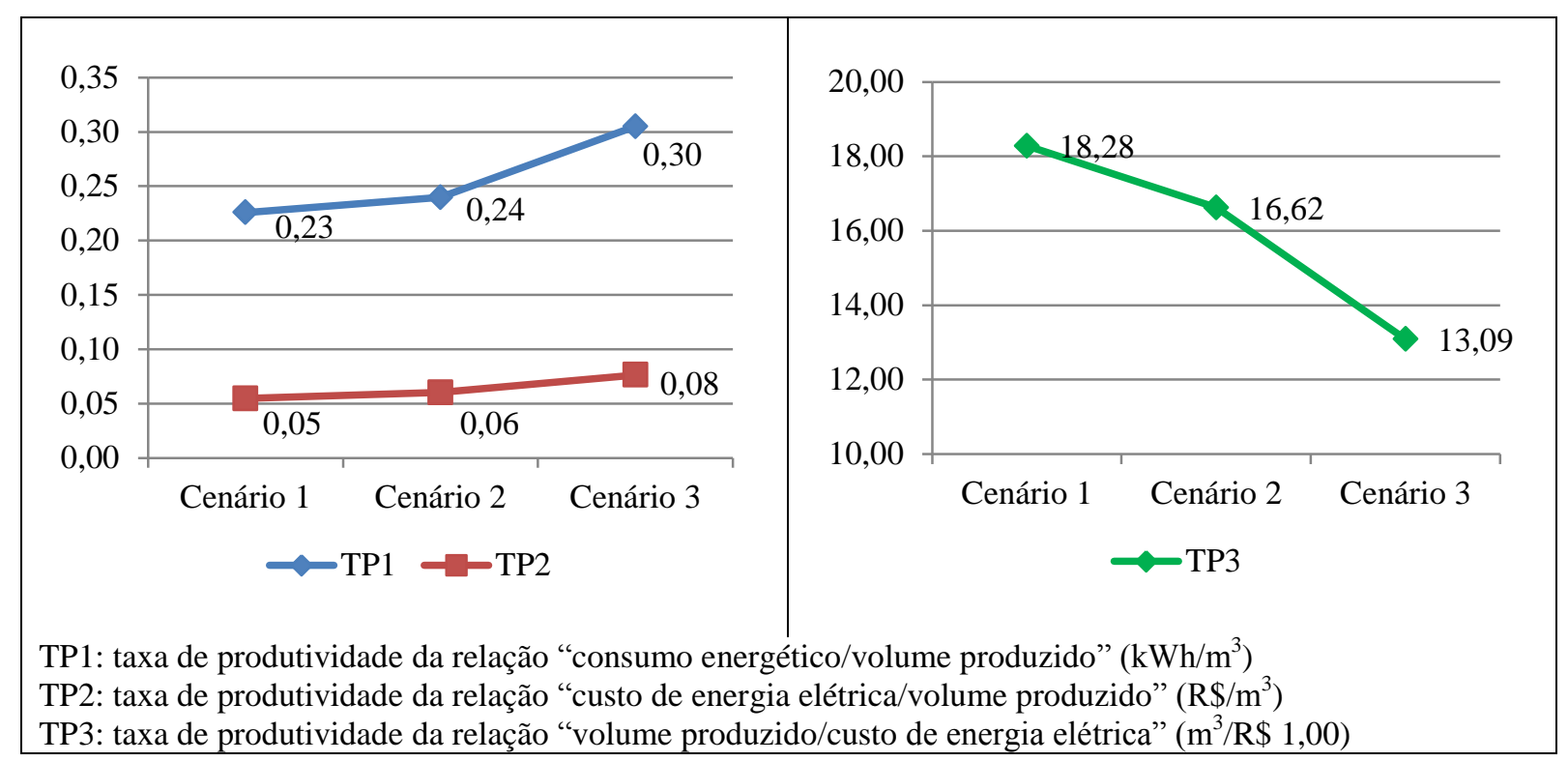

Figura 6.4 - Gráfico de comparação entre os cenários de simulação da explotação do SAB em SJRP com a demonstração da eficiência de produção de água

Ressalta-se que todas as análises comparativas dos cenários consideraram o mesmo rendimento dos sistemas de bombeamento, visando ressaltar as influências exercidas exclusivamente pelo aumento das vazões de explotação e os rebaixamentos da potenciometria associados.

Uma aproximação do cálculo da externalidade provocada pela intensificação dos cenários de explotação modelados pode ser estimada a partir da eficiência de produção. Desse modo, considerando os mesmos volumes de explotação simulados, porém mantendo-se a taxa de produtividade (TP3) no mesmo valor do cenário $1\left(18,28 \mathrm{~m}^{3} / \mathrm{R} \$ 1,00\right)$, os custos de energia deveriam ser de $\mathrm{R} \$ 266.525$ para o cenário 2 e $\mathrm{R} \$ 399.788$ para cenário 3, ou seja, 9\% e 39\% inferiores, respectivamente, aos custos calculados nos cenários 1 (R\$ 293.058) e 2 (R\$ $558.362)$.

Os valores das externalidades representariam, anualmente, cerca de $\mathrm{R} \$ 320.000$ para o cenário 2 e R\$1.900.000 para o cenário 3, de custos extras com energia elétrica advindos da diminuição da eficiência provocada pela intensificação dos rebaixamentos dos níveis potenciométricos do $\mathrm{SAB}$.

Ressalta-se que as estimativas de externalidade foram calculadas com base na eficiência do cenário 1 que já sofre os efeitos do uso intenso das águas subterrâneas, pois possui rebaixamentos de até $70 \mathrm{~m}$, se comparado às condições naturais de fluxo subterrâneo. 
Nesse elenco de dados, não é possível estimar as externalidades a partir de um cenário ideal de explotação, mas, certamente seriam maiores que as calculadas.

Considerando que o cenário 2 reflete as condições atuais de explotação do SAB em SJRP e que o cenário 1 refere-se às condições de explotação em 2008 ou em algum momento anterior, pode-se considerar a existência de reais externalidades de, no mínimo, R\$ 1 milhão, correspondendo ao valor estimado para a externalidade entre os cenários $1 \mathrm{e} 2$, projetada no período entre os cenários.

Diante do exposto, constata-se que o modelo de uso das águas subterrâneas do SAB em SJRP não ocorre dentro de padrões ideais de sustentabilidade, pois além de efeitos hidrogeológicos indesejáveis, ainda provoca o desperdício energético e sobrecustos aos usuários dos recursos hídricos subterrâneos, ou seja, a toda sociedade riopretense.

6.2.2 Análise do modelo de uso das águas subterrâneas pelos poços de abastecimento público e a avaliação de externalidades provocadas à coletividade pelo uso particular das águas subterrâneas

O cenário 4 simulou uma condição de explotação hipotética, na qual somente estão em operação os poços de abastecimento público, ou seja, os poços particulares das demais finalidades de uso foram "desligados" na modelação. O volume total explotado nesse cenário é de $47.000 \mathrm{~m}^{3} /$ dia, correspondendo à captação dos poços de abastecimento público com base nos dados de vazão medidos em 2008 (DAEE, 2008), dispostos na área de interseção dos modelos, de $340 \mathrm{~km}^{2}$.

Para a comparação dos efeitos ocorridos na simulação do cenário 4 , foram adotados apenas os valores de consumo e custos de energia elétrica relativos aos poços de abastecimento público para todos os cenários 1, 2, 3 e 4. Os valores dos parâmetros de interesse e dos dados de consumo utilizados nas avaliações estão apresentados na Tabela 5.3. A Figura 6.5 demonstra a comparação entre os valores de vazão, consumo e custo de energia dos poços de abastecimento público para os 4 cenários avaliados.

A análise da Figura 6.5 permite constatar que, para os cenários 1,2 e 3, verificou-se o mesmo comportamento avaliado na comparação contendo todos os poços, ou seja, maiores custos associados às maiores vazões de explotação. No entanto, ao comparar o cenário 4 verifica-se que, para uma explotação ligeiramente maior que o cenário 1, o consumo e o custo de energia são cerca de $48 \%$ inferiores que os calculados no cenário 1. 


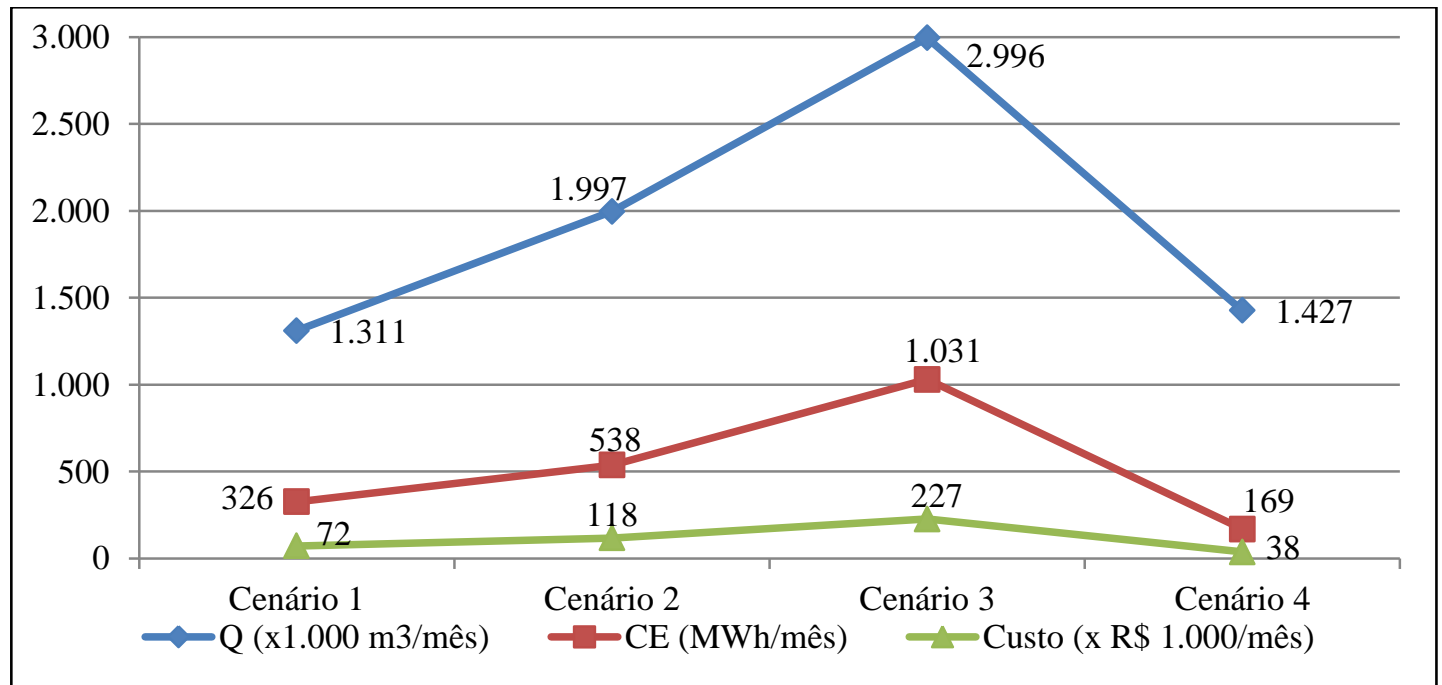

Figura 6.5 - Gráfico de comparação entre os cenários de simulação da explotação do SAB em SJRP pelos poços de abastecimento público com a demonstração da vazão de explotação, consumo e o custo de energia elétrica

O comportamento verificado com a avaliação do cenário 4 indica que o uso particular da água subterrânea provoca o incremento dos custos de produção de água para o abastecimento público.

As análises dos cenários discutidas anteriormente também ficam evidenciadas nos gráficos que demonstram as taxas de produtividade, conforme se observa na Figura 6.6.

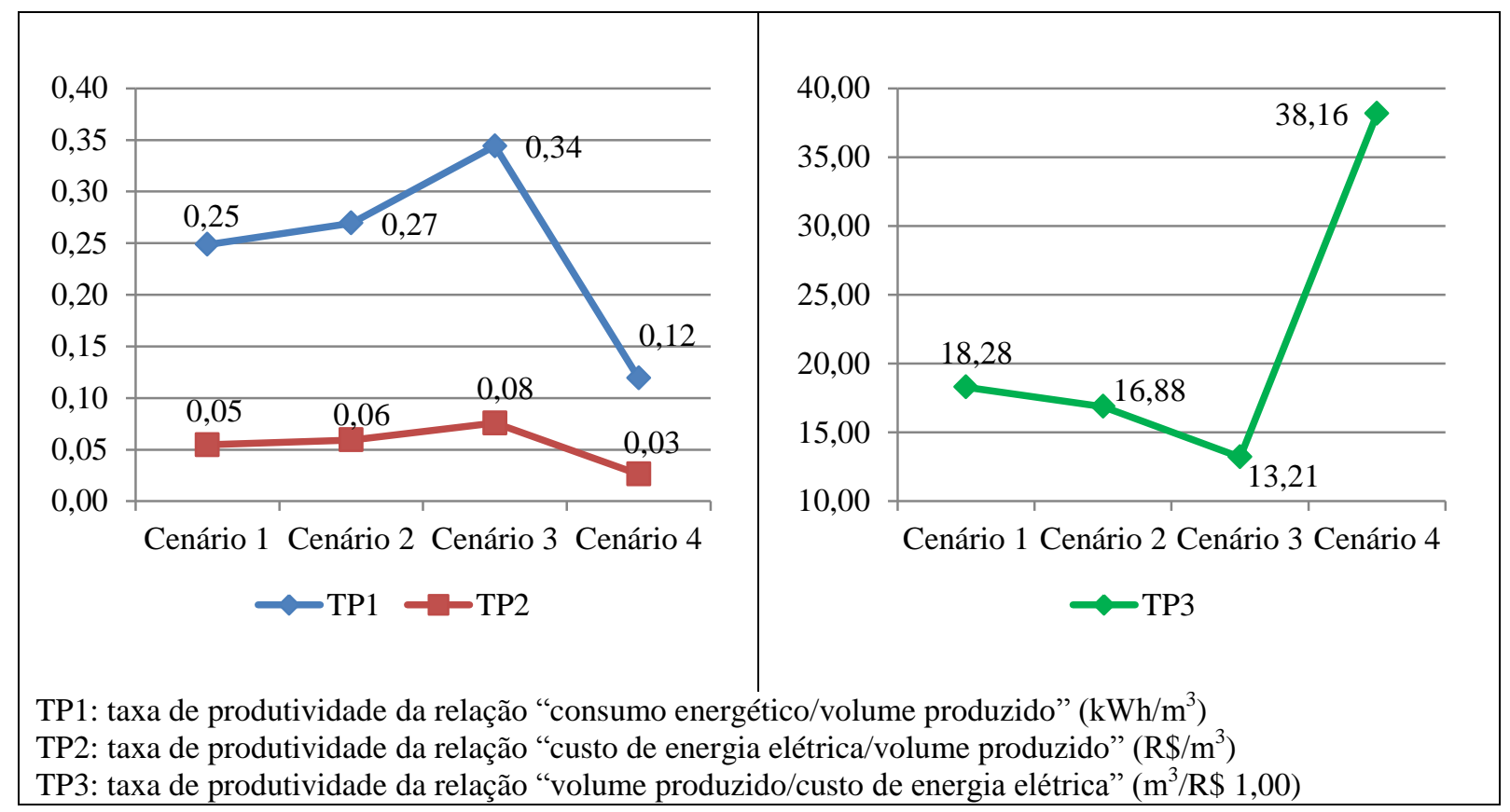

Figura 6.6 - Gráfico de comparação entre os cenários de simulação da explotação do SAB em SJRP demonstrando a eficiência de produção de água nos poços de abastecimento público 
A eficiência de todas as taxas de produtividade aumenta consideravelmente no cenário 4, em relação aos demais avaliados. A produção de água, a cada $\mathrm{R} \$ 1,00$ gasto com energia elétrica na explotação, aumenta mais de $100 \%$ entre os cenários 1 e 4 que possuem praticamente o mesmo volume explotado pelos poços de abastecimento público.

Neste caso, de análises comparativas dos cenários exclusivamente com dados dos poços públicos, também foi considerado o mesmo rendimento eletromecânico dos sistemas de bombeamento para que fossem ressaltadas exclusivamente as influências exercidas pelos modelos de uso das águas subterrâneas simulados em cada cenário.

A comparação feita a partir desses cenários, nos poços de abastecimento público, indica que ocorre uma externalidade provocada pelo uso particular das águas subterrâneas sobre o uso coletivo.

Seguindo uma abordagem teórica de estimar o valor dessa externalidade, pode-se considerar a adoção da eficiência avaliada no cenário $4\left(38,16 \mathrm{~m}^{3} / \mathrm{R} \$ 1,00\right)$, aplicada sobre o volume do cenário 2 que é considerado como a explotação atual do SAB. Desse modo, o custo de energia elétrica no cenário 2 deveria ser de $\mathrm{R} \$ 52.338$, significando que o uso privado impõe à coletividade um custo adicional na produção de água de $126 \%$, se comparado com o custo calculado para o cenário 2 (R\$ 118.335), em que os poços públicos operam “disputando água" com cerca de 1.700 poços particulares em operação na área de interseção dos modelos. Os valores discutidos são mensais, o que representaria um sobrecusto anual de energia elétrica de cerca de $\mathrm{R} \$ 790.000,00$, pagos pelos usuários do sistema público de abastecimento.

A avaliação efetuada anteriormente não pretendeu defender o uso das águas subterrâneas exclusivamente para o abastecimento público. Apenas objetivou demonstrar que existe uma carga financeira paga pela coletividade para que os usuários particulares façam uso dos recursos hídricos.

A externalidade identificada poderia ser calculada com base em dados mais consistentes com o objetivo de incluir nos mecanismos de cobrança pelo uso pelo uso da água uma parcela financeira a ser paga pelos usuários particulares como compensação aos sobrecustos causados aos usuários do sistema público de abastecimento. Nesse sentido, por exemplo, parte da arrecadação com a cobrança pelo uso da água poderia ser repassada à concessionária de abastecimento de água, no caso o Semae, que paga diretamente pelos custos extras de energia elétrica e que, consequentemente, repassaria aos usuários dos sistemas através da diminuição da tarifa de água. 


\subsubsection{Avaliação de custos extras de energia elétrica provocados pelo padrão de rendimento} dos sistemas de bombeamento em operação

O desenvolvimento deste estudo e o elenco de dados disponíveis permitiu também uma análise comparativa entre os cálculos teóricos adotados na avaliação dos cenários modelados numericamente com uma estimativa do consumo de energia calculado a partir de dados reais disponível no cadastro de poços (DAEE, 2008).

A estimativa do consumo de energia elétrica efetuada a partir da potência instalada foi apresentada no item 5.2, com base em um elenco de 273 poços situados na área de interseção dos modelos e que possuíam os dados de interesse. Neste tópico, essa estimativa de consumo de energia por dados existentes é denominada de "cadastro", sendo comparada com o consumo estimado nos cenários 1, 2, 3 e 4. Para tanto, foi realizada a comparação dos dados correspondentes ao mesmo universo de poços.

A Figura 6.7 apresenta a comparação entre os dados de vazão de explotação, consumo de energia e custos associados para os cenários modelados e para os dados do cadastro. Observa-se que a potência instalada nos sistemas de bombeamento em operação nos 237 poços analisados (dados do cadastro) possui consumo de energia e custos, em média, $120 \%$ superiores que os encontrados no cenário 1, que corresponde ao mesmo volume de explotação. O consumo calculado para o "cadastro" é superior, inclusive, aos obtidos no cenário 2 que possui uma explotação $58 \%$ superior.

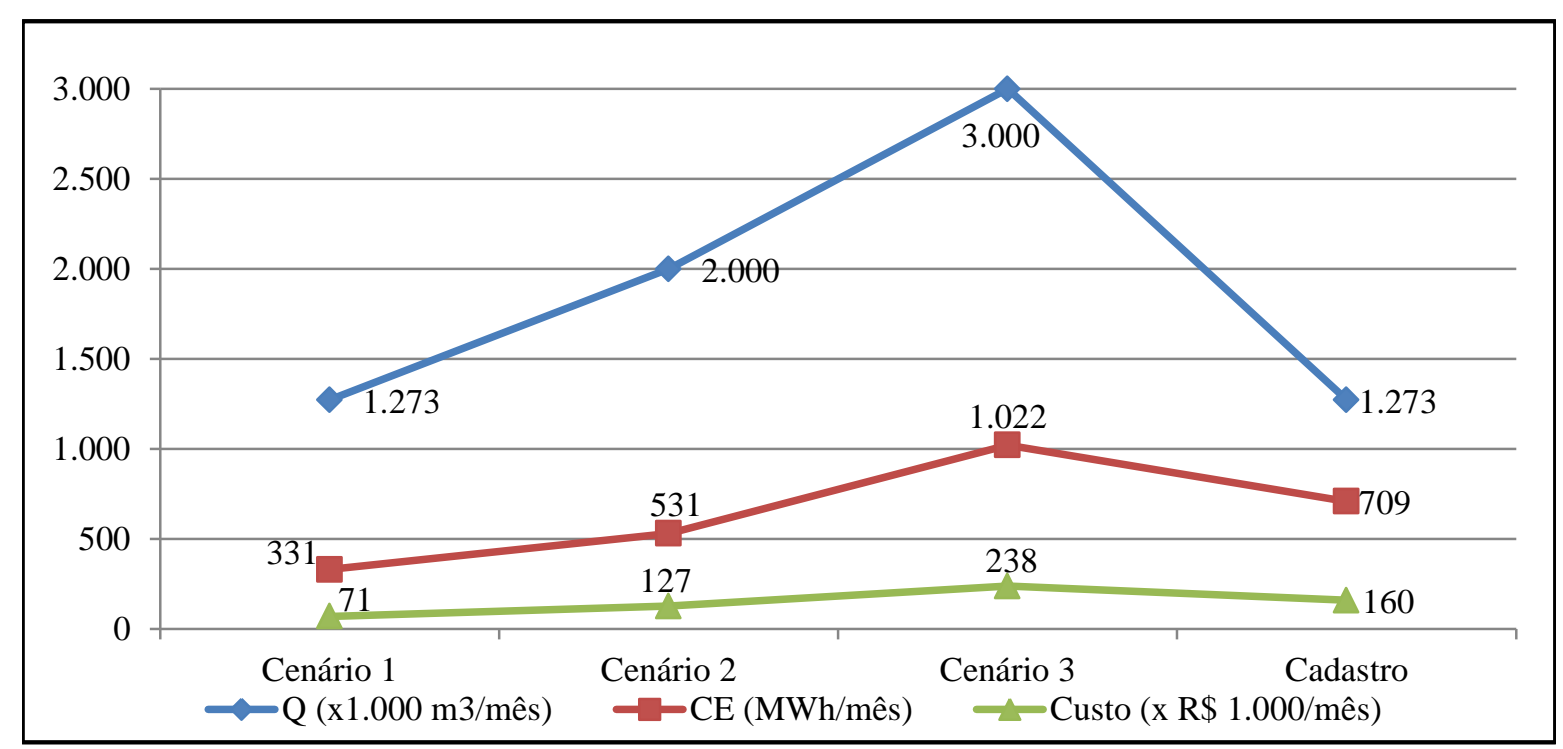

Figura 6.7 - Gráfico de comparação dos dados de vazão de explotação, consumo e custo de energia elétrica dos cenários simulados da explotação do SAB com as estimativas baseadas em dados reais do cadastro de poços do DAEE (2008) 
A análise dos custos e vazões, apresentada anteriormente, reflete nas taxas de produtividade da mesma maneira, conforme demonstrada na Figura 6.8. Desse modo, são encontradas menores eficiências dos sistemas instalados que os cálculos teóricos efetuados nos cenários 1,2 e 3 .

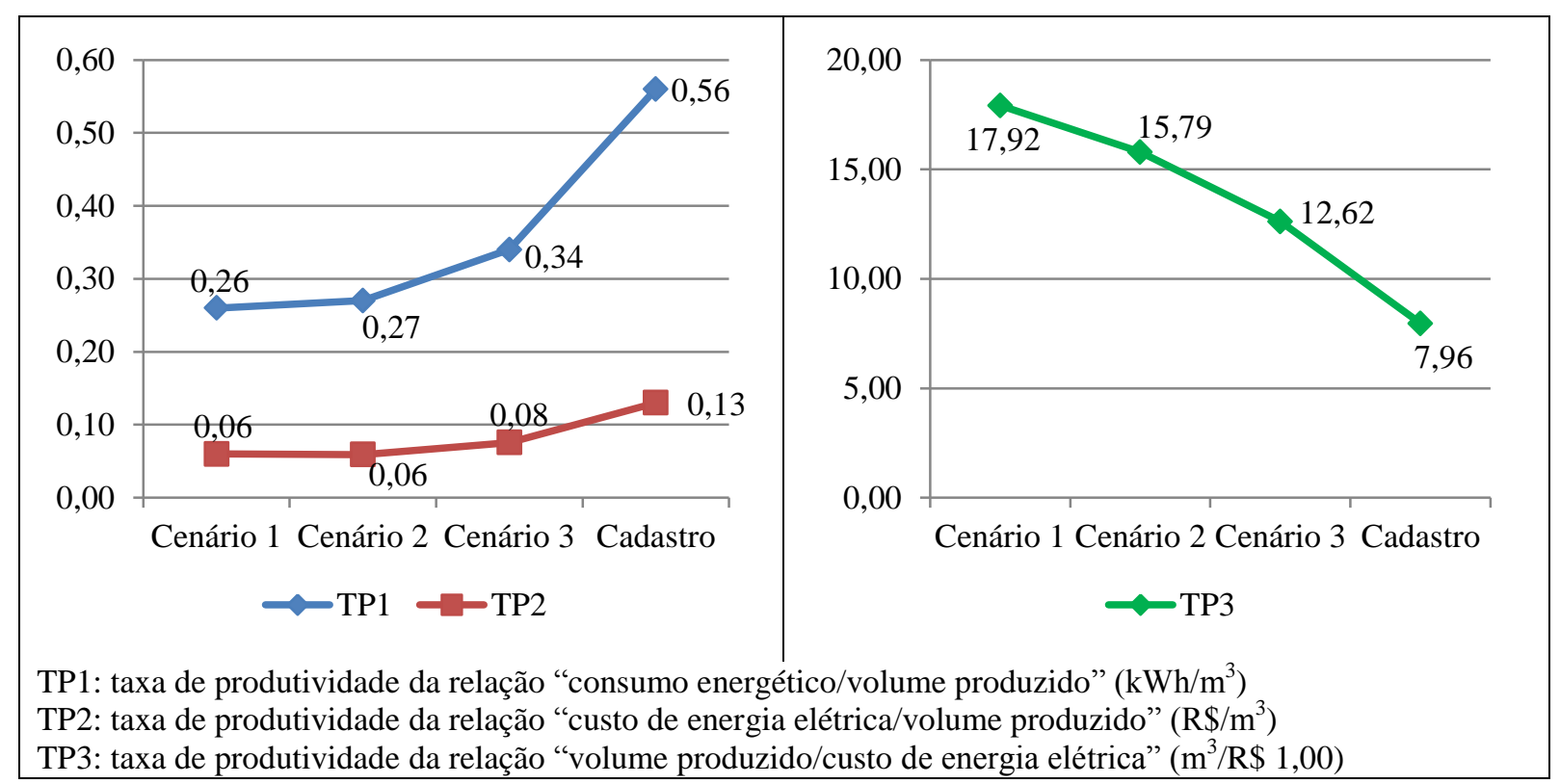

Figura 6.8 - Gráficos de comparação das taxas de eficiência de produção de água dos cenários simulados da explotação do SAB com as estimativas baseadas em dados reais do cadastro de poços do DAEE (2008)

A primeira análise que desdobra a partir das comparações demonstradas nas Figuras 6.7 e 6.8 é relacionada às profundidades médias do nível de água obtidas nos cenários modelados e às indicadas no cadastro de poços do DAEE (2008), neste caso, considerados os parâmetros de nível dinâmico registrados em todos os 273 poços avaliados, conforme demonstrado na Figura 6.9.

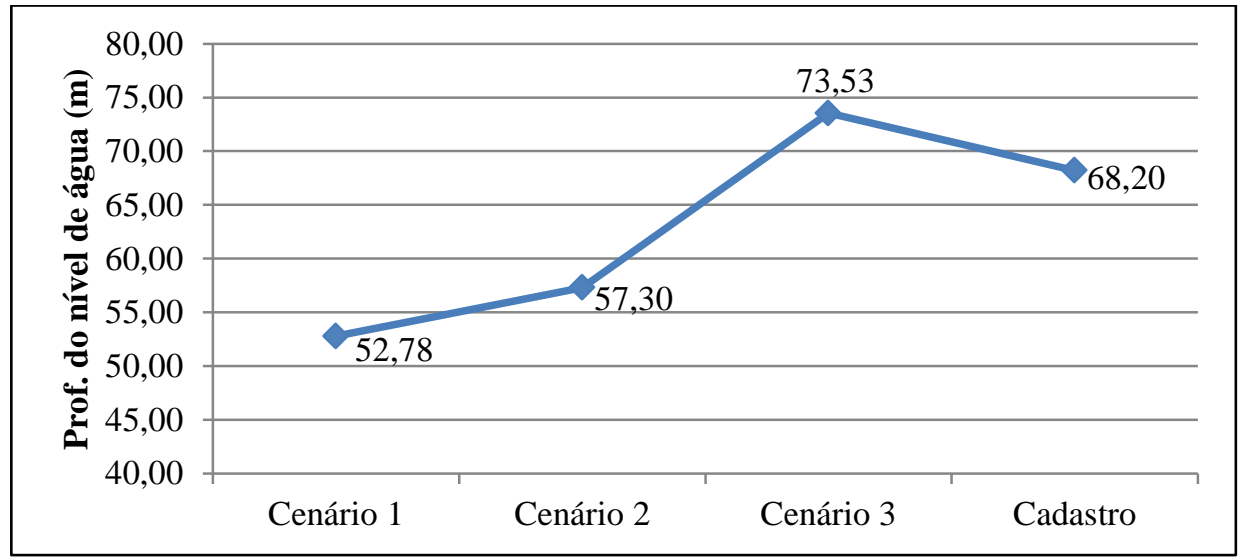

Figura 6.9- Gráfico de comparação da profundidade média do nível de água dos cenários simulados da explotação do SAB com a média dos dados do cadastro para o mesmo elenco de poços 
Observa-se que a profundidade média indicada no cadastro possui valor superior aos cenários 1 e 2 e inferior ao cenário 3, semelhante aos valores de consumo de energia, custo e eficiências calculados (Figuras 6.7 e 6.8). Desse modo, poderia ser justificado o padrão de consumo pela influência da profundidade registrada. A Figura 6.10 demonstra a forte correlação entre as profundidades médias e o custo mensal de energia elétrica.

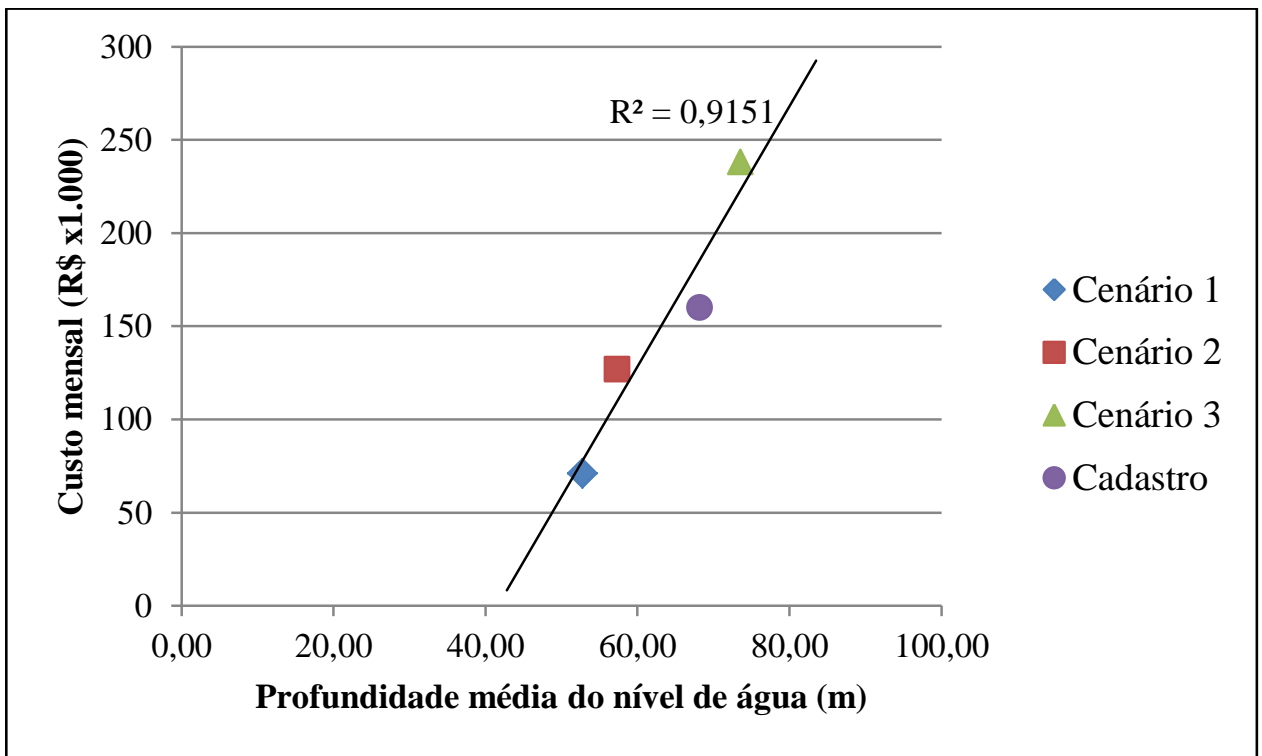

Figura 6.10 - Gráfico da correlação entre o custo de energia elétrica na explotação das águas subterrâneas e a profundidade média do nível de água

A avaliação feita ao contexto apresentado é que, de fato, os maiores valores de profundidade do nível dinâmico influenciaram as estimativas de consumo e custo de energia do "cadastro". Entretanto, considera-se que o espaço amostral utilizado para essa análise está elevando a profundidade média do nível de água (rebaixamento), por tratar-se de dados pontuais de cada poço, provenientes de ensaios de bombeamento que determinaram o nível dinâmico da vazão máxima ensaiada. Além disso, o universo dessa análise representa somente $15 \%$ do total de poços existentes na área modelada, sendo plausível inferir que as profundidades médias obtidas nas modelações sejam mais representativas de toda a dinâmica de fluxo que os dados pontuais de ensaios de bombeamento.

A Figura 6.11 demonstra uma nova comparação entre os cenários e os dados do cadastro, sendo recalculada a estimativa dos dados do cadastro, substituindo-se as profundidades do nível dinâmico pela profundidade de nível de água obtidas na modelação numérica do cenário 1. Essa nova abordagem elimina as possíveis distorções acerca dos valores de nível dinâmico adotados para os cálculos do "cadastro 1", bem como, demonstra 
que, ainda assim, os dados do "cadastro 2" possuem menor eficiência das taxas de produtividade, devido ao baixo rendimento dos sistemas de bombeamento, conforme discussão a seguir.

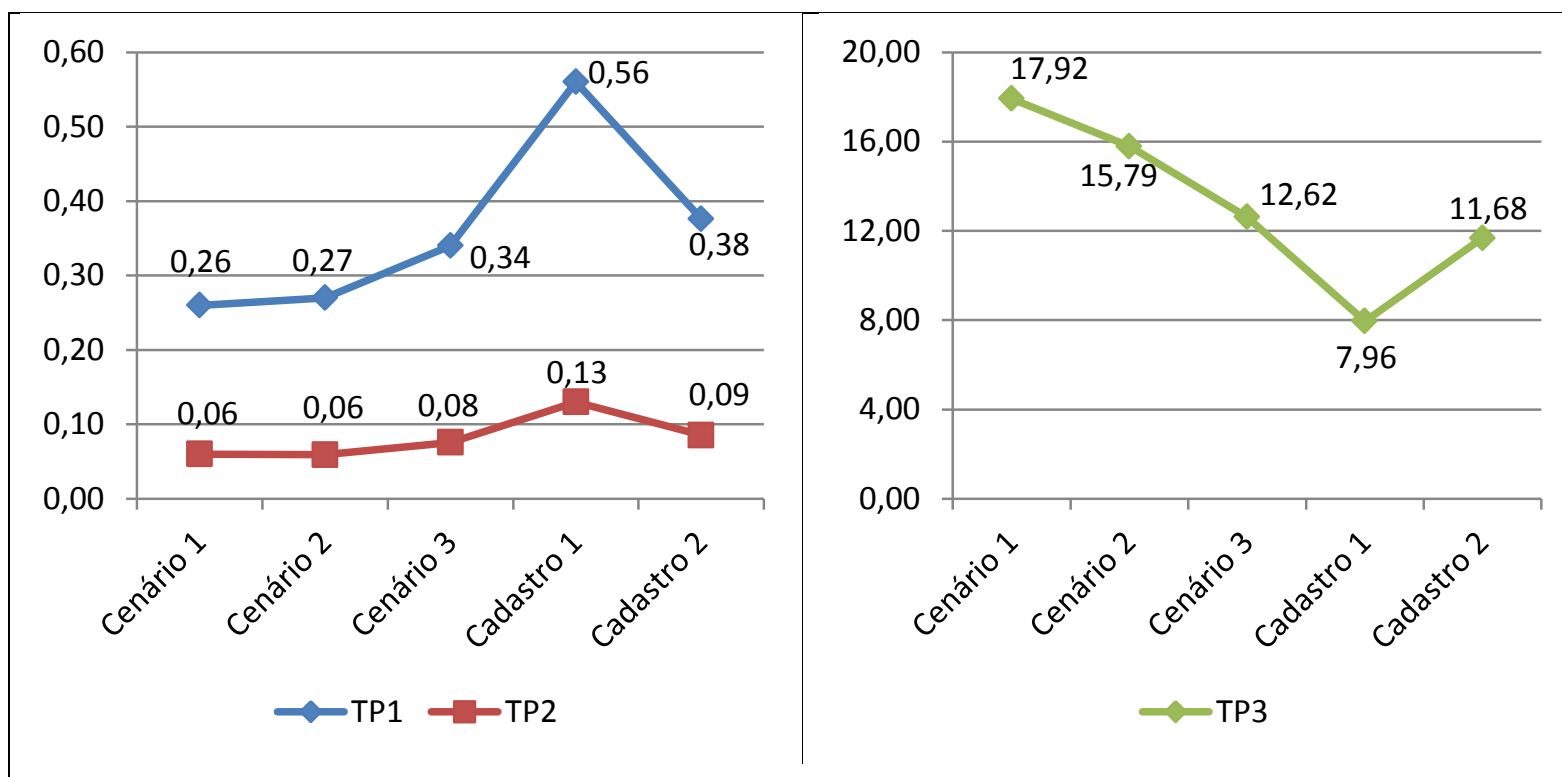

Cadastro 1 - estaminativas obtidas com dados reais do cadastro de poços, considerando os dados de nível dinâmico como as alturas manométricas de bombeamento;

Cadastro 2 - estaminativas obtidas com dados reais do cadastro de poços, considerando as profundidades do nível de água obtidas no cenário 1 como as alturas manométricas de bombeamento;

TP1: taxa de produtividade da relação "consumo energético/volume produzido" $\left(\mathrm{kWh} / \mathrm{m}^{3}\right)$;

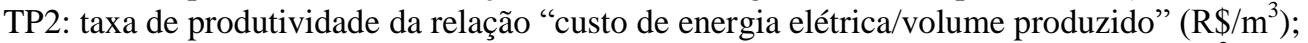

TP3: taxa de produtividade da relação "volume produzido/custo de energia elétrica" $\left(\mathrm{m}^{3} / \mathrm{R} \$ 1,00\right)$;

Figura 6.11 - Gráficos de comparação das taxas de eficiência de produção de água dos cenários simulados da explotação do SAB com duas estimativas baseadas em dados reais do cadastro de poços do DAEE (2008) e diferentes dados de profundidade de nível de água

Os desdobramentos da análise efetuada anteriormente permitiu uma avaliação acerca da influência no consumo de energia elétrica da explotação decorrente dos rendimentos dos sistemas de bombeamento.

Os rendimentos dos sistemas de bombeamento $\left(\rho_{\mathrm{s}}\right)$ calculados com base em dados reais do cadastro mostraram elevada amplitude de valores (Figura 5.10) com média de 38\%. Nos cálculos do consumo de energia elétrica dos cenários modelados, o rendimento foi arbitrado em $65 \%$. Desse modo, obviamente, ocorrem maiores consumos e custos para as condições reais de potência dos equipamentos instalados.

A principal avaliação advinda dos esclarecimentos sobre os rendimentos instalados, em relação aos projetados, é que existe um custo extra de energia na captação das águas subterrâneas advindos de aspectos técnico-operacionais dos poços, além das externalidades do modelo de uso das águas subterrâneas já discutidas anteriormente. 
Existem inúmeras medidas que podem ser adotadas no sentido de aumentar o rendimento dos sistemas de bombeamento, com efeito na melhoria da eficiência na produção de água. Esta pesquisa não objetivou esse tipo de avaliação, embora possa registrar que o rendimento médio instalado é baixo, discordante dos padrões atuais de sustentabilidade.

Para ilustrar a discussão acima, com base das taxa de produtividade (TP1), estima-se um desperdício anual de cerca de $\mathrm{R} \$ 500$ mil e de $1.800 \mathrm{kWh}$, proveniente dos baixos rendimentos dos sistemas de bombeamento instalados.

A avaliação do consumo de energia na explotação das águas subterrâneas, comparando os cenários modelados e os dados de capacidade instalada disponíveis no cadastro de poço, demonstrou que existem desperdícios de energia elétrica decorrentes do baixo desempenho dos rendimentos dos sistemas de bombeamento e, consequentemente, a geração de custos extras na explotação, além das externalidades advindas do modelo de uso das aguas subterrâneas.

\subsection{AVALIAÇÃO DA EXISTÊNCIA DE SUPEREXPLOTAÇÃO DO SAB EM SJRP}

A luz do conhecimento trazido pelos autores que inspiraram o desenvolvimento desta pesquisa, relativo à análise multifocal do uso intenso das águas subterrâneas, bem como, embasado pelos dados e resultados ora alcançados seguem algumas contribuições sobre a avaliação da ocorrência de superexplotação do SAB.

Considerando o caráter multifocal defendido, o enfoque e os dados desta pesquisa podem subsidiar a avaliação da ocorrência de superexplotação apenas parcialmente por aspectos econômicos e hidrogeológicos.

Os estudos hidrogeológicos do DAEE (2008) indicaram uma disponibilidade hídrica de $437,4 \mathrm{~m}^{3} / \mathrm{dia} / \mathrm{km}^{2}$, correspondendo a um volume de explotação sustentável do SAB em SJRP. Deve-se destacar ainda que as águas subterrâneas do SAB são recursos hídricos renováveis, desde que adequadamente explotados e protegidos de contaminações, pois são anualmente recarregados pelas precipitações pluviométricas.

A disponibilidade hídrica sustentável do SAB corresponde a um volume de 318.427 $\mathrm{m}^{3} /$ dia para toda a área de estudo $\left(728 \mathrm{~km}^{2}\right)$ e de $148.716 \mathrm{~m}^{3} /$ dia para a área de interseção dos modelos numéricos $\left(340 \mathrm{~km}^{2}\right)$, demonstrada na Figura 3.23 . 
Os volumes explotados do SAB em SJRP calculados neste estudo totalizam 122.521 $\mathrm{m}^{3} /$ dia em toda a área. Esse cálculo de explotação foi realizado a partir de dados registrados no cadastro do DAEE (2008).

Devido à abrangência parcial do cadastro e aos naturais aumentos da demanda de 2008 a 2012, foi apontado que a explotação relativa ao cenário $2\left(160.178 \mathrm{~m}^{3} / \mathrm{dia}\right)$ pode corresponder a estimativa do volume atualmente retirado do SAB em SJRP, na área de abrangência do modelo.

Considerando toda a área de estudo, a disponibilidade hídrica possui comprometimento de $38 \%$ pela explotação com os dados de 2008 e de $50 \%$ pela explotação modelada no cenário 2 .

$\mathrm{Na}$ análise simplista realizada acima, estaria descartada definitivamente qualquer avaliação de superexplotação. No entanto, o cenário 2 da modelação numérica, tido como uma possível explotação atual do $\mathrm{SAB}$, corresponde a uma retirada de $471,1 \mathrm{~m}^{3} / \mathrm{dia} / \mathrm{km}^{2}$ situada praticamente na área do perímetro urbano de SJRP. Essa explotação do cenário 2 é cerca de $8 \%$ superior à disponibilidade hídrica sustentável determinada nos estudos do DAEE (2008). Adicionalmente a esse desequilíbrio hídrico na zona urbana de SJRP, destaca-se também de acordo com esta pesquisa:

- a constatação de externalidades provocadas pelo modelo de uso das águas subterrâneas, aumentando as despesas com energia elétrica nas captações;

- a elevada taxa de consumo per capta, provavelmente incluindo usos desregrados, desperdícios e perdas;

- a possibilidade de manejo da problemática, visto que existe disponibilidade hídrica na própria franja urbana.

As análises e ponderações efetuadas acima configuram razões suficientes para caracterizar a ocorrência de superexplotação das águas subterrâneas do SAB na zona urbana de SJRP, a partir dos fatores enfocados nesta pesquisa.

Deve-se destacar que, na visão multifocal da avaliação da superexplotação deveriam ser analisados os efeitos positivos propiciados pelo modelo de uso das águas subterrâneas, tais como nível de desenvolvimento econômico e social. No entanto, diante da possibilidade de estabelecer um modelo com melhores padrões de sustentabilidade do uso da água subterrânea e do consumo energético, para este autor, parece não se justificar o modelo atualmente utilizado.

No entorno do perímetro urbano de SJRP, em uma distância inferior a $10 \mathrm{~km}$, ocorre, segundo o estudo do DAEE (2008), uma disponibilidade hídrica no SAB com potencialidade 
para a captação de cerca de $130.000 \mathrm{~m}^{3} / \mathrm{dia}\left(\sim 1,5 \mathrm{~m}^{3} / \mathrm{s}\right)$, adicionalmente aos volumes atualmente em explotação. Essa potencialidade hídrica é suficiente para ampliar a explotação atual existente em todo o município em cerca de $70 \%$.

$\mathrm{O}$ potencial hídrico do $\mathrm{SAB}$ na área de abrangência deste estudo permite reverter o cenário de superexplotação existente no perímetro urbano e, ainda, prover o suprimento adicional de até $1,0 \mathrm{~m}^{3} / \mathrm{s}$ para o atendimento às futuras demandas, de maneira sustentável e segura com baixos custos de implantação e de operação, se comparado com alternativas de captações superficiais. Para tanto, são necessárias adequadas medidas de controle, gestão do uso dos recursos hídricos, fiscalização ao cumprimento das legislações vigentes, planejamento integrado de ações e apoio institucional e político.

Embora tenha sido avaliada a existência de superexplotação do SAB na zona urbana de SJRP, este cenário corresponde a uma condição gerada por fatores ligados ao modelo de desenvolvimento e de uso das águas subterrâneas que pode tecnicamente ser revertido. 


\section{CONCLUSÕES}

As atividades desenvolvidas permitiram atingir os objetivos propostos e os resultados esperados, sendo a seguir apresentadas as principais conclusões alcançadas nesta pesquisa.

A caracterização do uso das águas subterrâneas do Sistema Aquífero Bauru (SAB) em São José do Rio Preto (SJRP) foi efetuada com base no cadastro de poços consistido pela Servmar Ambiental, no âmbito dos estudos hidrogeológico contratados pelo DAEE (2008), verificando-se que o município conta com mais de 2.000 poços tubulares com profundidade média de 112 m, dos quais, cerca de $10 \%$ são poços de abastecimento público e os demais são poços particulares para as demais finalidades de uso (doméstico, industrial, comercial, irrigação, dessedentação animal e recreação) com destaque aos usos doméstico (residências e condomínios) e comercial que, juntos, representam mais de $50 \%$ dos poços existentes. Desse total de poços, apenas $18 \%$ possuem outorga de uso das águas emitida pelo órgão gestor dos recursos hídricos DAEE.

Estima-se que o cadastro de poços do DAEE tenha uma elevada abrangência dos poços existentes na zona urbana de SJRP, superior a 80\%. Desse modo, considera-se que as caracterizações, os cálculos e as projeções realizadas a partir desses dados sejam, em geral, representativos das condições existentes na área de estudo e, sobretudo, no perímetro urbano de SJRP.

A explotação do SAB em SJRP, com base nos dados de 2008 foi calculada em $122.521 \mathrm{~m}^{3} /$ dia, sendo estimado um volume atualmente explotado de cerca de $160.000 \mathrm{~m}^{3} /$ dia, considerando o volume captado por poços existentes não incluídos no cadastro e o natural crescimento de poços e demandas no período de 2008 a 2012. Os poços de abastecimento público respondem por $41 \%$ do volume total explotado, o uso doméstico por $33 \%$ e os outros $26 \%$ são explotados para as demais finalidades de uso.

O cálculo da explotação do SAB permitiu compor o real cenário de abastecimento de água de SJRP, constituído por cerca de $38.000 \mathrm{~m}^{3} /$ dia captados do Sistema Aquífero Guarani, $30.000 \mathrm{~m}^{3} /$ dia do rio Preto (fonte superficial), $50.000 \mathrm{~m}^{3} /$ dia do $\mathrm{SAB}$ pelos poços públicos e $72.000 \mathrm{~m}^{3} /$ dia do $\mathrm{SAB}$ pelos poços particulares, totalizando $190.000 \mathrm{~m}^{3} /$ dia.

A composição do suprimento de água de SJRP também permitiu observar que as fontes de água subterrânea representam $84 \%$ do volume total e que o SAB é responsável pelo fornecimento de $64 \%$ do total produzido pelas três fontes hídricas. Nota-se também que os 
poços particulares produzem $38 \%$ do volume total, permitindo afirmar que o suprimento de água de SJRP é, no atual momento, dependente das alternativas individuais de abastecimento.

O suprimento de água de SJRP corresponde ao consumo per capta de 381 1/hab.dia, sendo $116 \%$ superior à taxa média de consumo para o Estado de São Paulo, segundo dados do SNIS (176 1/hab.dia). No cálculo do consumo de água foi subtraída uma parcela de cerca $38.000 \mathrm{~m}^{3} /$ dia relativa às perdas de água do sistema de abastecimento público. Esse consumo per capta, provavelmente inclui usos desregrados e desperdícios do recurso hídrico advindos do fácil acesso e baixos custos típicos do modelo de uso das águas subterrâneas do SAB.

O modelo de uso das águas subterrâneas do SAB em SJRP vem provocando efeitos indesejáveis ao sistema hidrogeológico com destaque aos rebaixamentos dos níveis potenciométricos evidenciados desde o início da década de 90 e demonstrados por modelações numéricas do fluxo subterrâneo realizadas em estudos anteriores.

Os cenários de modelação numérica utilizados na avaliação dos efeitos do uso intenso das águas subterrâneas nos custos de energia elétrica de explotação simularam diferentes volumes de explotação, demonstrando diferentes condições de rebaixamento dos níveis potenciométrico do aquífero em uma área de $340 \mathrm{~km}^{2}$ abrangendo todo o perímetro urbano de SJRP que possui $92 \mathrm{~km}^{2}$ e áreas circunvizinhas.

O cenário 1 simulou uma explotação de $98.000 \mathrm{~m}^{3} /$ dia, registrando profundidade média do nível de água de 52,22 m e rebaixamento máximo de 104,61 m. O consumo de energia elétrica foi calculado em $670 \mathrm{MWh} / \mathrm{mês}$ (megawatts·hora/mês), o custo mensal de energia foi de R\$162.393. Esse cenário refletiu condições baseadas nos dados de 2008.

No cenário 2, a explotação simulada foi de $160.000 \mathrm{~m}^{3} /$ dia, a profundidade média do nível de água foi de 56,03 m, o rebaixamento máximo foi de 107,35 m (Figura 5.14), o consumo de energia foi de $1.168 \mathrm{MWh} /$ mês e o custo mensal, R\$ 293.058. Esse cenário simulou um volume de explotação estimado para as condições atuais.

No cenário 3, a explotação simulada foi de $240.000 \mathrm{~m}^{3} /$ dia, a profundidade média do nível de água foi de 71,80 m, o rebaixamento máximo foi de 135,00 m, o consumo de energia foi de 2.229 MWh/mês e o custo mensal foi de R \$ 558.362. Esse foi um cenário hipotético de aumento da explotação do cenário 2 em $50 \%$.

O cenário 4 simulou uma condição hipotética de explotação somente dos poços de abastecimento públicos com vazões semelhantes às praticadas no cenário 1 para esses poços. Esse cenário seria equivalente a todos os poços particulares estarem desligados. $\mathrm{O}$ volume de explotação modelado foi de $47.000 \mathrm{~m}^{3} /$ dia, a profundidade média do nível de água foi de 
42,78 m, o rebaixamento máximo foi de 70,00 m, o consumo de energia foi de170 MWh/mês e o custo mensal, de R $\$ 37.381$.

Os resultados alcançados com a comparação entre os cenários 1, 2 e 3, a partir dos dados de consumo de energia elétrica, custo e taxas de produtividade constataram a ocorrência de incrementos no consumo e no custo de energia elétrica advindos do modelo de uso das águas subterrâneas do SAB em SJRP.

Os aumentos nas despesas com energia elétrica avaliados nesses contextos podem ser caracterizados como externalidades provocadas pelo modelo de desenvolvimento da explotação das águas subterrâneas e atingem direta ou indiretamente todos os usuários desse recurso hídrico.

Os resultados permitiram avaliar também a existência de externalidades provocadas pelo uso particular das águas subterrâneas à coletividade, ou seja, a captação por meio dos poços privados incrementam as despesas com energia elétrica na captação dos poços públicos, aumentando os custos da empresa de saneamento, neste caso o Semae, e, consequentemente, dos usuários do sistema público de abastecimento.

Além das externalidades provocadas pelo modelo de uso das águas subterrâneas, avaliou-se também existência de custos extras de energia provocados pelo baixo desempenho dos sistemas de bombeamento instalados nos poços. Neste caso, os incrementos de consumo são relacionados às questões técnico-operacionais dos poços e, apesar de não terem relação com os aspectos hidrogeológicos, representam desperdícios financeiros e de energia elétrica, caminhando na direção contrária das tendências de sustentabilidade atualmente em vigor.

A explotação do cenário 2, estimado como compatível das condições atuais de explotação, corresponde a uma retirada de $471,1 \mathrm{~m}^{3} / \mathrm{dia} / \mathrm{km}^{2}$. Esse valor é cerca de $8 \%$ superior à disponibilidade hídrica sustentável determinada nos estudos hidrogeológicos do DAEE (2008), indicando a ocorrência de um desequilíbrio hídricos, cujos efeitos negativos vem sendo constatados em diversos trabalhos.

No entorno do perímetro urbano de SJRP, em uma distância inferior a $10 \mathrm{~km}$, ocorre, segundo o estudo do DAEE (2008), uma disponibilidade hídrica no SAB com potencialidade para a captação de cerca de $130.000 \mathrm{~m}^{3} /$ dia $\left(\sim 1,5 \mathrm{~m}^{3} / \mathrm{s}\right)$, adicionalmente aos volumes atualmente em explotação. Essa potencialidade hídrica é suficiente para ampliar a explotação atual existente em todo o município em cerca de $70 \%$.

Esta pesquisa avalia a existência de superexplotação do SAB na zona urbana de SJRP, com base, principalmente, na explotação em patamares superiores à disponibilidade hídrica sustentável; na constatação de externalidades provocadas pelo modelo de uso das águas 
subterrâneas, aumentando as despesas com energia elétrica nas captações; na elevada taxa de consumo per capta, provavelmente incluindo usos desregrados, desperdícios e perdas; na possibilidade de manejo da problemática, visto que existe disponibilidade hídrica na própria franja urbana.

Complementarmente, pondera-se que o desenvolvimento do cadastro de poços e os demais produtos dos estudos do DAEE (2008) representaram um enorme avanço ao conhecimento do cenário de explotação das águas subterrâneas do SAB em SJRP e um importante ferramental para a gestão, a partir dos quais foram possíveis novas abordagens e avaliações sobre o modelo de uso dos recursos hídricos subterrâneos. 


\section{REFERÊNCIAS BIBLIOGRÁFICAS}

ALMEIDA, F. F. M. de. Fundamentos geológicos do relevo paulista. Boletim do Instituto Geográfico e Geológico, São Paulo, v. 41, p 167 -262, 1964.

ABNT. ASSOCIAÇÃO BRASILEIRA DE NORMAS TÉCNICAS. Poço tubular - Projeto de poço tubular para captação de água subterrânea - NBR 12.212. Rio de Janeiro: ABNT, 2006, $10 \mathrm{p}$.

BARCELOS, J. H.; SUGUIO, K. Correlação e extensão das unidades estratigráficas do Grupo Bauru, definidas em território paulista, nos estados de Minas Gerais, Goiás, Mato Grosso do Sul e Paraná. In: SIMPÓSIO REGIONAL DE GEOLOGIA, 6, 1987, Rio Claro. Atas.... Rio Claro: Sociedade Brasileira de Geologia, 1987. Vol. 1, p. 313-321.

BARCHA, S. F. Água e abastecimento urbano em São José do Rio Preto. In: CONGRESSO BRASILEIRO DE ÁGUAS SUBTERRÂNEAS, 10, 1998, São Paulo. Anais... São Paulo: Associação Brasileira de Águas Subterrâneas, 1998. (1 CD-ROM).

BARCHA, S.F. Urbanização e Impactos sobre o Aquífero. In: SIMPÓSIO BRASILEIRO DE RECURSOS HÍDRICOS, 12, 1997, Vitória. Anais... Vitória: ABRH, 1997, v. 4, p. 683687.

BARCHA S.F. Nitrato em água subterrânea no meio urbano. In: CONGRESSO BRASILEIRO DE GEOLOGIA - SBG/SP, 37., 1992, São Paulo. Anais... São Paulo: [s.i.],1992, p. 200-201.

BARCHA, S.F. Aspectos geológicos e provinciais hidrogeológicas da Formação Bauru na região norte-ocidental do estado de São Paulo. 1980. p 203. Dissertação (Mestrado) Instituto de Geociência, Universidade de São Paulo, São Paulo, 1980.

BATEZELLI, A.; PERINOTTO,J.A.J.; ETCHEBEHERE, M. L. C.; FULFARO,V.J.; SAAD, A. R. Redefinição litoestratigráfica da unidade Araçatuba e da sua extensão regional na Bacia Bauru, Estado de São Paulo, Brasil. In: SIMPÓSIO SOBRE CRETÁCEO DO BRASIL, 5., SIMPOSIO SOBRE EL CRETÁCICO DE AMÉRICA DEL SUR, 1., 1999, Serra Negra. Boletim de Resumos... São Paulo: Universidade Estadual Paulista, 1999, p $195-200$.

BROWN; G.M. 2000. Renewable natural resources management and use without markets. Journal of Economic Literature, [S.I.], v. 38, n. 4, p. 875-914, 2000. 
CAMPOS, J. E.; ALBUQUERQUE FILHO, J. L.; ODA, G. H.; IRITANI, M. A.; PERROTTA, M. M.; SILVEIRA, R. E. I. da; TAKAHASHI, A. T. Carta hidrogeológica do Estado de São Paulo (Brasil) na escala 1:1.000.000 - Resultados parciais. In: JOINT WORLD CONGRESS ON GROUNDWATER, 1., 2000, Fortaleza. Anais... Fortaleza: ABAS, 2000. 1 CD-ROM.

CARVALHO, A. M. Modelagem numérica como ferramenta para gestão das águas subterrâneas em São José do Rio Preto. 2012. 118f. Tese (Relatório de Qualificação), Instituto de Geociências, Universidade de São Paulo, São Paulo, 2012.

CARVAlHO, A. M.; HIRATA, R. C. A.; SIMONATO, M.D.; SARTORATO, A. C. Modelação numérica em áreas urbanas com intensa explotação das águas subterrâneas. Em preparação.

CETESB. Companhia Ambiental do Estado de São Paulo. Relatório de qualidade das águas subterrâneas do Estado de São Paulo Período 2004-2006. São Paulo: CETESB, 2007.

CPFL PAULISTA. Tarifas para o fornecimento de energia elétrica. Disponível em:

<http://www.cpfl.com.br/Informaccedilotildees/TaxaseTarifas/tabid/206/Default.aspx $>$ . Acesso em: 16 dez. 2012.

CUSTODIO E. Aquifer overexploitation: what does it mean?. Hydrogeology Journal, [S.I.], v.10, p. 254-277, 2002

CUSTODIO, E. Hydrogeological and hydrochemical aspects of aquifer overexploitation. In: INTERNATIONAL CONGRESS OF THE INTERNATIONAL ASSOCIATION OF HYDROGEOLOGISTS, 23. ,1992, Puerto de la Cruz, Tenerife, Spain. Selected Papers on Aquifer Overexploitation. Simmers, F. Villarroya, L.F. Rebollo (eds.). Hannover: Heise, 1992, v. 3, p 3- 28.

CUSTODIO E.; LLAMAS M. R. Intensive use of groundwater: introductory considerations. In: M. R. LLAMAS; E. CUSTODIO (EDS.). Intensive use of groundwater challenges and opportunities. Madrid: A.A. Balkema, 2003. p. 3-12.

CUSTODIO, E.; LLAMAS, M. R. Hidrología subterrânea. 2 ed. Barcelona: Omega, 2001. v. $1, \mathrm{p} 1157$.

DAEE. Departamento de Águas e Energia Elétrica. Delimitação de Áreas de Restrição e Controle de Captação e Uso de Águas Subterrâneas no Município de São José do Rio 
Preto - Bloco A - Aquífero Sedimentar - Relatório Técnico Final. São Paulo: Servmar Ambiental / DAEE, 2008. V. 5, mapas e DVD.

DAEE. Departamento de Águas e Energia Elétrica. Estudo de Águas Subterrâneas: Região administrativa 7, 8 e 9: Bauru, São José do Rio Preto e Araçatuba. São Paulo: ENCO/DAEE, 1976.

FERNANDES, L. A. Estratigrafia e evolução geológica da parte oriental da Bacia Bauru (Ks, Brasil). 1998. 216 f (3 mapas). Tese (Doutorado) - Instituto de Geociências, Universidade de São Paulo, São Paulo, 1998.

FERNANDES, L. A. A cobertura cretácea suprabasáltica do Paraná e Pontal do Paranapanema (SP): os grupos Caiuá e Bauru. 1992. 129 f. Dissertação (Mestrado) Instituto de Geociências, Universidade de São Paulo, São Paulo, 1992.

FERNANDES, L.A; COIMBRA, A.M. Revisão estratigráfica da parte oriental da bacia Bauru (Neocretáceo). Revista Brasileira Geociência, São Paulo, v. 30, n. 4, p. 717-728, 2000.

FERNANDES, L.A; COIMBRA, A.M. A Bacia Bauru (Cretáceo Superior, Brasil). Anais da Academia Brasileira de Ciências, São Paulo, v. 68, n. 2, p 195-205, 1996.

FERNANDES; L.A.; COIMBRA, A. M. O Grupo Caiuá (Ks): revisão estratigráfica e contexto deposicional. Revista Brasileira de Geociências, São Paulo, v. 24, n. 3, p 164176, 1994

FETTER, C. W. Applied Hydrogeology. 4 ed.. New Jersey: Prentice-Hall Inc., 2001, v. 1, p 598.

GARRIDO A.; LIVINGSTON M. L. Economic and financial perspectives on intensive groundwater use. In: M.R. Llamas \& E. Custodio (eds.) Intensive use of groundwater challenges and opportunities. 1 ed. Madrid: A.A. Balkema, 2003. p 207-225.

HIRATA, R. C. A. Recursos hídricos subterrâneos e as novas exigências ambientais. Revista IG., São Paulo, v. 14, n. 1, p. 39-62, 1993.

HOWARD, K.W.F. Impacts of urban development on groundwater. In: K.W.F. Howard; E. Eyles (ed). Environmental geology of urban areas. Special publication of the Geological Association of Canada. [S.I.]: Geological Association of Canada, 1997, v. 3, p 93-104.

IBGE. Instituto Brasileiro de Geografia e Estatística. 2010. Censo Demográfico 2010. Ministério do Planejamento, Orçamento e Gestão. Disponível em: 
〈www.ibge.gov.br/home/estatistica/populacao_sao_paulo.pdf $>$. Acesso em: 26 maio 2011.

IBGE. Instituto Brasileiro de Geografia e Estatística. Pesquisa Nacional de Saneamento Básico. Rio de Janeiro: Ministério do Planejamento, Orçamento e Gestão, 2010. p. 229.

IPT. Instituto de Pesquisas Tecnológicas. Relatório um de Situação dos Recursos Hídricos da Bacia do Turvo/Grande. São Paulo: IPT, 2006. p. 225. (Relatório Técnico No 90.644205).

IPT. Instituto de Pesquisas Tecnológicas. Diagnóstico da situação atual dos Recursos Hídricos e estabelecimento de diretrizes técnicas para a elaboração do Plano da Bacia Hidrográfica do Turvo/Grande: Relatório Final. São Paulo: IPT/Digeo, 1999. (Relatório Técnico nº 40.515).

IPT. Instituto de Pesquisas Tecnológicas. Mapa Geológico do Estado de São Paulo. São Paulo. São Paulo: IPT, 1981a. Escala 1:500.000.

IPT. Instituto de Pesquisas Tecnológicas. Mapa Geomorfológico do Estado de São Paulo: São Paulo. São Paulo: IPT, 1981b. Escala 1:1.000.000.

IRITANI, M. A.; EZAKI, S. As águas subterrâneas do Estado de São Paulo. 2 ed.. São Paulo: Secretária de Estado do Meio Ambiente - SMA, 2009. p 104.

IRITANI, M. A.; ODA, G. H.; KAKAZU, M. C.; CAMPOS, J. E.; FERREIRA, L. M. R.; SILVEIRA, E. L.; AZEVEDO, A. A. B. de. Zoneamento das Características Hidrodinâmicas (Transmissividade e Capacidade Específica) do Sistema Aquíffero Bauru no Estado de São Paulo - Brasil. In: CONGRESSO MUNDIAL INTEGRADO DE ÁGUAS SUBTERRÂNEAS,1, CONGRESSO ABAS, 11, ALHSUD, 5., 2000. Fortaleza, CE, Brasil. Boletim de Resumos.... Fortaleza: ABAS, 2000, p147.

LIMA. A. A. Hidrogeologia do sistema aquífero Bauru no município de São José do Rio Preto (SP). 2004. 82f. Dissertação (Mestrado) - Instituto de Geociências e Ciências Exatas, Campus de Rio Claro, UNESP, Rio Claro, 2004.

LLAMAS,M. R. Lessons Learnt from the impact of the neglected role of groundwater in Spain's water policy. Elsevier Science, Amsterdam, The Netherlands, p 63-81, 2003.

LLAMAS M.R.; CUSTODIO, E. Intensive use of groundwater: a new situation which demands proactive action. In: M. R. LLAMAS; E. CUSTODIO (eds.). Intensive use of groundwater challenges and opportunities. Madrid: A.A. Balkema, 2003. p. 13-34. 
LLAMAS, M. R.; MARTINEZ CORTINA, L. Groundwater irrigation and poverty alleviation. In:. IWRA REGIONAL SYMPOSIUM: WATER FOR HUMAN SURVIVAL, 2002. New Delhi, Central Board for Irrigation and Power, v. 2, p. 134 143. 2002

LLAMAS, M. R.; MARTÍNEZ-SANTOS, P. Intensive Groundwater Use: Silent Revolution and Potential Source of Social Conflicts. Journal of Water Resources Planning and Management, [S.I.], p. 337-342, 2005

LLAMAS, M.R.; MARTÍNEZ-SANTOS P. Coping with the Silent Revolution of intensive groundwater use. In: INT. WATER DEMAND CONF, 2004, [S.I.]. p. 14. CD-Rom.

LLAMAS, M.R.; BACK, W.; MARGAT J. 1992. Groundwater use: equilibrium between social benefits and potential environmental costs. Applied Hydrogeology, [S.1.], v. 2; p. 3-14

MARGAT, J. The overexploitation of aquifer. In: INTERNATIONAL CONGRESS OF THE INTERNATIONAL ASSOCIATION OF HYDROGEOLOGISTS, 23 rd., 1992, Puerto de la Cruz, Tenerife, Spain. Selected Papers on Aquifer Overexploitation. Simmers, F. Villarroya, L.F. Rebollo (eds.). Hannover: Heise, 1992, v. 3, p. 29-40.

MEZZALIRA, S. Aspectos bioestratigráficos e hidrogeológicos do Grupo Bauru. In: ENCONTRO DE GEOLOGIA E HIDROGEOLOGIA DO GRUPO BAURU NO ESTADO DE SÃO PAULO,1, 1981. São Paulo. Publicação Especial Coletânea de Trabalhos e Debates. São Paulo: SBG - Núcleo São Paulo; ABAS, p. 20 - 35.

OLIVEIRA, J. N. Ferramental de Gestão de Águas Subterrâneas para a cidade de São José do Rio Preto, SP. 2002. 127f. Tese (Doutorado) - Departamento de Hidráulica e Saneamento, Escola de Engenharia de São Carlos, Universidade de São Paulo, São Carlos, 2002.

PAULA E SILVA, F. Geologia de Subsuperfície e Hidroestratigrafia do Grupo Bauru no estado de São Paulo. 2003. 201f. Tese (Doutorado) - Instituto de Geociências e Ciências Exatas, Campus de Rio Claro, UNESP, Rio Claro, 2003.

PAUlA E SILVA, F.; CHANG, H.K.; CAETANO-CHANG, M.R. Caracterização das unidades neocretáceas da Bacia do Paraná na região de São José do Rio Preto (SP) com base na análise de perfis geofísicos e suas implicações estratigráficas. In: SIMPÓSIO SOBRE O CRETÁCEO DO BRASIL, 6, e SIMPÓSIO SOBRE EL CRETÁCEO DE 
AMERICA DEL SUR, 2, 2002, São Pedro. Boletim de Resumos... Rio Claro: Universidade Estadual Paulista, 2002, p. 345-349.

PERRONI, J. C. A. Avaliação do consumo de energia elétrica para produção de água subterrânea - o caso do abastecimento público da cidade de São Carlos - SP. 2005. 130f. Dissertação (Mestrado) - Departamento de Hidráulica e Saneamento, Escola de Engenharia de São Carlos, Universidade de São Paulo, São Carlos, 2005.

PERRONI, J. C. A.; WENDLAND, E. Avaliação da eficiência energética em poços profundos utilizados para abastecimento público. RBRH - Revista Brasileira de Recursos Hídricos, São Paulo, v. 11, n. 3, p 123-134, 2006

PMSJRP. Prefeitura Municipal de São José do Rio Preto. Conjuntura econômica de São José do Rio Preto. São José do Rio Preto: Secretaria Municipal de Planejamento e Gestão Estratégica, 2011. 25 ed.

PMSJRP. Prefeitura Municipal de São José do Rio Preto. Conjuntura econômica de São José do Rio Preto. São José do Rio Preto: Secretaria Municipal de Planejamento e Gestão Estratégica, 2010. 24 ed.

PMSJRP. Prefeitura Municipal de São José do Rio Preto. Conjuntura econômica de São José do Rio Preto. São José do Rio Preto: Secretaria Municipal de Planejamento e Gestão Estratégica, 2009. 23 ed

PMSJRP. Prefeitura Municipal de São José do Rio Preto. Conjuntura econômica de São José do Rio Preto. São José do Rio Preto: Secretaria Municipal de Planejamento e Gestão Estratégica, 2008. 22 ed.

RECESA. Abastecimento de água gerenciamento de perdas de água e energia elétrica em sistemas de abastecimento: guia do profissional em treinamento nível 2. Salvador: RECESA, 2008, Secretária de Saneamento Ambiental/RECESA, p. 139.

REDDY, V. R. Costs of resource depletion externalities: a study of groundwater overexploitation in Andhra Pradesh, India. Environment and Development Economics, [S.I.], v. 10, p. 533-556, 2005

ROCHA, G. A.; BERTACHINI, C. A.; CAMPOS, H. C. N. S.; CAIXETA, J. B. Tentativa de zoneamento das características hidráulicas e hidroquímicas do Aquífero Bauru. In: ENCONTRO DE GEOLOGIA E HIDROGEOLOGIA DO GRUPO BAURU NO 
ESTADO DE SÃO PAUlO, 1, 1981. São Paulo. Publicação Especial Coletânea de Trabalhos e Debates. São Paulo: SBG - Núcleo São Paulo; ABAS, p.37-57.

SABESP. Companhia de Saneamento do Estado de São Paulo. Números da Sabesp. Disponível em: <http://site.sabesp.com.br/site/interna/Default.aspx?secaoId=4>. Acesso em: 05 out. 2012.

SÃO PAUlO (Estado). Conselho Estadual de Recursos Hídricos. Plano Estadual de Recursos Hídricos 2004 - 2007. São Paulo: DAEE, 2006. Resumo, p. 92.

SÃO PAULO (Estado). Conselho Estadual de Recursos Hídricos. Mapa de águas subterrâneas do Estado de São Paulo: escala 1:1.000.000. São Paulo: DAEE, IG, IPT, CPRM, 2005, v 1 (texto), 2 (mapa em CD-ROM).

SNIS. Sistema Nacional de Informações sobre Saneamento. Diagnóstico dos serviços de água e esgotos - 2009 - textos e tabelas. Brasília: Ministério das Cidades, Secretaria Nacional de Saneamento Ambiental, 2011. 616 p.

SNIS. Sistema Nacional de Informações sobre Saneamento. Diagnóstico dos serviços de água e esgotos - 2008. Brasília: Ministério das Cidades, Secretaria Nacional de Saneamento Ambiental, 2008. Planilhas Excel com dados municipais - Planilha 3: informações municipais.Disponível em:

http://www.snis.gov.br/PaginaCarrega.php?EWRErterterTERTer=85, acessado em 02/02/2012.

SHAH, T.; D. MOLDEN, R; SAKTHIVADIVEL; D. SECKLER. The global groundwater situation: Overview of opportunities and challenges. Sri Lanka: International Water Management Institute, 2000.

SOARES, P. C.; LANDIM, P. M. B.; FÚLFARO, V. J.; SOBREIRO NETO A. F. Ensaio de caracterização do Cretáceo no Estado de São Paulo: Grupo Bauru. Revista Brasileira Geociências, São Paulo, v. 10, n. 3, p 177-185, 1980.

SOPHOCLEOUS, M. From safe yield to sustainable development of water resources - the Kansas experience. Journal of Hydrology , [S.I.], v. 235, p 27-43, 2000

TERI. The Energy and Resources Institute. Climate Change and Water Vulnerability Strategies and Practices for Emerging Water Management and Governance Challenges. In: CONFERENCE ON CLIMATE CHANGE - UNFCCC, 15., 2009, Copenhagen. White Paper. p. 12. 
TSUTIYA, M. T.. Redução do Custo de Energia em sistemas de abastecimento de água. 1 ed. São Paulo: ABES - Associação Brasileira de Engenharia Sanitária e Ambiental, 2001. p 185 .

TSUTIYA, M. T. Redução do custo de energia elétrica em estações elevatórias de água e esgoto. In: CONGRESSO BRASILEIRO DE ENGENHARIA SANITÁRIA E AMBIENTAL,8., 1997, [S.I.]. São Paulo: ABES - Associação Brasileira de Engenharia Sanitária e Ambiental, 1997, p. 2611-2625.

TSUTIYA, M. T.; DAVID, A. C. Eficiência energética em sistema de abastecimento de água da cidade de Ubatuba, Estado de São Paulo. In: CONGRESSO BRASILEIRO DE ENGENHARIA SANITÁRIA E AMBIENTAL, 23., 2005, Campo Grande. São Paulo: ABES - Associação Brasileira de Engenharia Sanitária e Ambiental, 2005.

UNESCO. United Nations Educational, Scientific, and Cultural Organization. Water in a changing world - The World Water Development Report 3. [S.I]: UNESCO, 2009. p. 319.

UNESCO. United Nations Educational, Scientific, and Cultural Organization. Water in a changing world - The World Water Development Report 3. [S.I]: UNESCO, 2003. P 36.

WENDLAND, E.; SIMONATO, M. D.; LAPICCIRELLA, E.S.; HIRATA, R.. Modelo numérico de escoamento subterrâneo na região de São José do Rio Preto. Revista Brasileira de Águas Subterrânea, São Paulo, (no prelo). 